Gebhard Fartacek (ed.)

\title{
Druze Reincarnation Narratives
}

Previous Life Memories, Discourses, and the Construction of Identities

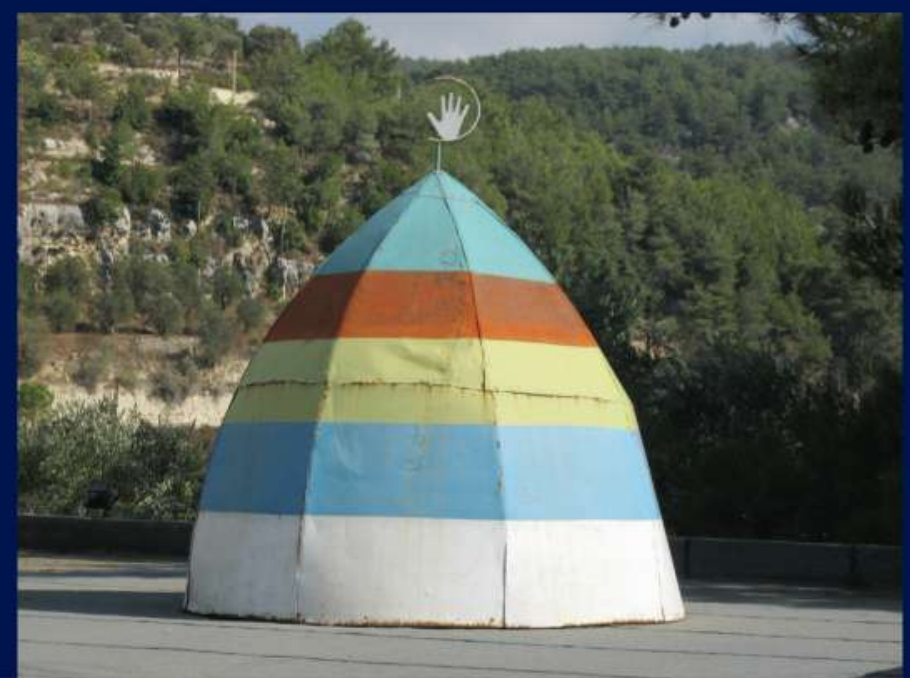


Gebhard Fartacek (ed.)

\section{Druze Reincarnation Narratives}

This book follows the journey of Druze individuals who can remember their former lives and go on search for their previous families. For the Druze, an ethno-religious minority in the Middle East split between different nation-states, such cases and related discourses embody ambivalent bridges between personal, familial, and ethnic identities.

The contributions in this book, presented by Eléonore Armanet, Nour Farra Haddad, Gebhard Fartacek, Tobias Lang, Lorenz Nigst, and Salma Samaha, draw on ethnographic inquiries and illuminate the broad field of Druze conceptions of rebirth and group coherence against the backdrop of everyday challenges and recent conflicts in the Middle East and beyond.

\section{The Editor}

Gebhard Fartacek holds a PhD in social anthropology from the University of Vienna and works as a senior research associate at the Austrian Academy of Sciences (AAS). His ethnographic field research focuses on pilgrimage and local conceptions of holiness (baraka), stories and discourses dealing with jinns and the evil eye, ethnic-religious boundaries, conflict resolution, and coping strategies in the Middle East. 
Druze Reincarnation Narratives 

Gebhard Fartacek (ed.)

\section{Druze Reincarnation Narratives}

Previous Life Memories, Discourses, and the

Construction of Identities 


\section{Bibliographic Information published by the Deutsche Nationalbibliothek}

The Deutsche Nationalbibliothek lists this publication in the Deutsche Nationalbibliografie; detailed bibliographic data is available online at http://dnb.d-nb.de.

\section{Library of Congress Cataloging-in-Publication Data}

A CIP catalog record for this book has been applied for at the Library of Congress.

This research was funded in whole, or in part, by the Austrian Science Fund (FWF) [Stand Alone Project P28736]. For the purpose of open access, the author has applied a CC-BY public copyright licence to any Author Accepted

Manuscript version arising from this submission.

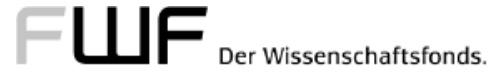

Cover illustration: The dome of a burial site in the typical five-color combination of the Druze (Shūf Mountains, Lebanon). (c) Gebhard Fartacek, 2016.

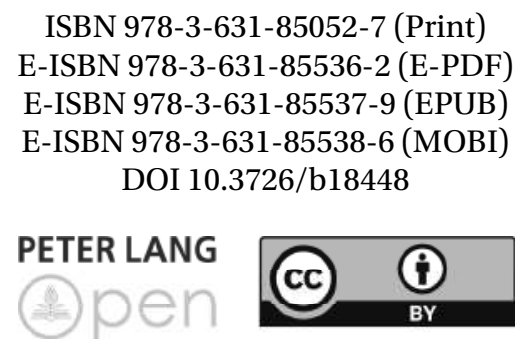

Open Access: This work is licensed under a Creative Commons Attribution CC-BY 4.0 license. To view a copy of this license, visit

https://creativecommons.org/licenses/by/4.0/

(c) Gebhard Fartacek, 2021

Peter Lang - Berlin · Bern · Bruxelles · New York · Oxford · Warszawa · Wien This publication has been peer reviewed. www.peterlang.com 


\section{Table of Contents}

Introductory Remarks

9

Gebhard Fartacek

Ethnographic Insights: Narratives Dealing with Previous Life Memories Among the Druze

Lorenz Nigst

The Different Appearance of the Identical: Some Thoughts About How the Druze Discourse on Transmigration Connects Lives

Eléonore Armanet

"For us, death does not exist and the taqammus keeps us

close": Reincarnation and Subjectivities in the World of the Druze

Lorenz Nigst

Leaving Things in Abeyance: Druze Shaykhs Speaking About

Transmigration on TV

Nour Farra Haddad

Devotions to a Druze Saint: From Philosopher to Founder Saint of the

Community 145

Salma Samaha

Landscape Imprint of Mortuary Dwellings in Different Sociocultural

Context: A Comparison of Christian and Druze Funerary Practices in

Lebanon and Syria 161

Tobias Lang

The Druze as a Political Entity in the Modern State: An Overview of the Contemporary Situation in Syria, Lebanon and Israel 179

Gebhard Fartacek

Final Comment: Reincarnation and Viability in a Fractured World 211 
Appendix 1: Short Biographies of the Authors

Appendix 2: Table of Figures

219 



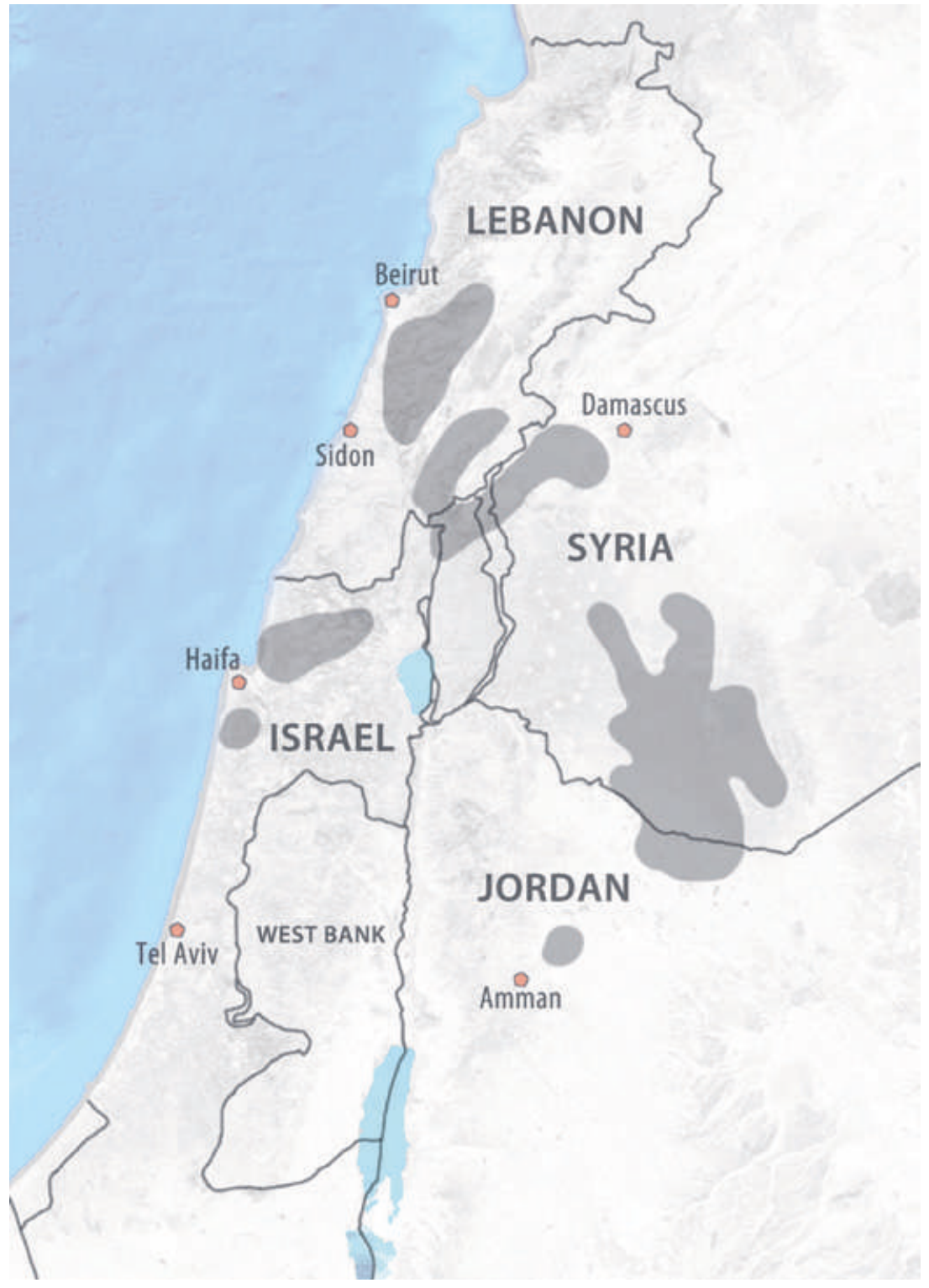

Fig. 1: Main settlement areas of the Druze in the Middle East. Map overview created using Google Maps. Map: Sita Treytl, 2021. 


\section{Introductory Remarks}

Imagine a child of two or three who is gradually learning to talk and keeps referring to a previous life. A child who says they are married, have children, and live in a nice house, perhaps even mentioning its location, the names of family members and close intimates, certain events, tragic accidents and the specific circumstances of how they died. Imagine such a child expressing yearning and a desire to return to their previous family. Seeking to understand the information supplied by the child, their family might begin to investigate, or the child might make their own way to the location of their past life unaided and find a family where somebody who died two or three years ago matches the descriptions given by the child exactly. Under cross-examination, the child might prove their previous identity with their knowledge of secrets and other details that could only have been known to the deceased. Such situations arise in Druze communities and are dealt with in a broad spectrum of ways. In some cases, "speaking" children are brusquely rejected by their previous families, but in others, "speakers" are welcomed by their previous families and reintegrated into family life in a manner comparable to an adoption: such children grow up in two families, their past-life family and the family into which they have been reborn.

The Druze use the term nuṭq (or: 'amalìyat an-nutq; literally, an operation of remembering and retelling) to describe such cases of individuals who have memories of a previous life and speak of them. While such cases are always isolated occurrences - since possessing the ability to remember a previous life is believed to be rare and extraordinary - "speakers" (sing. masc.: nātiq, sing. fem: nātiqa; pl. näțiqūn or, in dialect, nāțiqīn) within the Druze community are not seen as eccentric or as esotericists; such cases are, rather, eminently compatible with the Druze worldview and the Druze doctrine of the transmigration of souls (taqammuss). They are, indeed, central to the Druze religion with its cultural history influences from Neoplatonic emanationist cosmology (metempsychosis).

For this religious community of an estimated four million people living chiefly in the nation states of Syria, Lebanon, Israel and Jordan and separated from one another in recent history by minefields and electric fences, discourses on rebirth are highly meaningful for the collective construction of identity and group coherence as well as for individuals. The Druze conception of reincarnation follows specific rules and holds that neither ethnic-religious nor gender boundaries can be crossed by transmigrating souls: Druze are always reborn as Druze, just as men are reincarnated as men and women as women. This supplies an additional epistemological justification for the obligatory endogamy practised rigorously by the Druze in the Middle East. A theory often advanced in 
this context holds that the Druze community has "always" existed (albeit not always under the same name $)^{1}$ and that the number of souls (arwāh; sing. rūh has remained constant in every epoch.

The present publication aims to make a modest contribution towards illuminating ideas and discourses on individuals who can remember a previous life ( $j \bar{l} l m \bar{a} d \bar{\imath}$, literally a "past generation" and theologically a "past life circuit of the soul") that are prevalent in the Druze community from the perspectives of multiple disciplines. It begins with an ethnographic section containing ten excerpted interviews with "speakers" or relatives narrating their own experiences. The interview excerpts have been taken from biographic-narrative or episodic interviews with Lebanese, Israeli and Syrian Druze individuals carried out in parts with refugees from Syria in Germany and Austria and during ethnological fieldwork in Lebanon and Israel/Palestine in the course of a major research project which is described in more detail below. They provide insights into the nature and the narrative structuring of such cases and shed light on how "speakers" are assimilated into existing kinship and social networks. The interviews are followed by an ethnographic analysis that proceeds from the assumption that social recognition as a reincarnated person can potentially facilitate the formation of new extended family alliances and enable specific forms of kinship construction. This analysis identifies several factors that play a role in these cases and presents an initial set of working hypotheses.

The construction of personal identities in the context of the Druze conceptions of reincarnation is also a topic taken up by Lorenz Nigst. His contribution has, like Gebhard Fartacek's, emerged from the empirical results of their joint project work (see below). However, its focus (on the epistemological problems "speaking" children present for the uniqueness of human individuals) is more theoretical.

1 The word "Druze" is, strictly speaking, an exonym derived from the name of an Ismaili missionary from Buchara who came to Cairo in $1007 \mathrm{CE}$ and was known as ad-Darzì. Together with his teacher Hamza ibn 'Alì, he publicly proclaimed the divinity of the sixth Fatimid Caliph al-Hākim bi-amr Allāh (985-1021 CE). This step marked - from the external perspective of Islamic studies, at any rate - the schism of the Druze from Ismaili Shia Islam (the Sevener Shiites). The Druze describe themselves as al-muwahhidūn (literally: those who believe in the unity of God; see the contributions by Armanet and Nigst in this volume). 
This is followed by a chapter by the French social anthropologist Eléonore Armanet, who carried out her empirical studies among the Druze in northern Israel and has already published a sterling monograph under the title Le ferment et la grâce: Une ethnographie du sacré chez les Druzes d'Israël (2011). Her contribution to this volume aims to illuminate the topic of reincarnation among the Druze from a holistic perspective. Connections between personal constructions of identity and the cosmological principles of the Druze as part of a common identity are traced with reference to theories from anthropology and psychology.

In a separate contribution, Lorenz Nigst also explores the issue of reincarnation in the media discourses of Druze spiritual leaders and the fascinating ambivalences they reveal.

This is followed by two contributions by Lebanese researchers that place nutq and taqammus in the wider context of the Druze conceptions of death and life. The social anthropologist Nour Farra Haddad focuses on saints that play an important role in local pilgrimage cultures as mythological owners of holy sites and bearers of divine blessings (baraka). Core elements of the Druze conception of the transmigration of souls in the context of the emanation doctrine are clarified using the example of the famous pilgrimage site Nabi BahäadDìn (aka Nabī Lūkā) in Shārūn (on Mount Lebanon). Like the saints' sanctuaries with the five colours of the Druze that are prominently visible from afar, the cemeteries where ordinary people are buried can also be seen as markers of ethnic and territorial identities. The Lebanese landscape ecologist and cultural geographer Salma Samaha concerns herself with Druze cemeteries and their spatial implications in her contribution. She compares Druze cemeteries in the Shūf Mountains (in Lebanon) with cemeteries in the Syrian province of Suwaydā', contrasts Druze and Christian cemeteries and reaches conclusions about the different modes of conceiving of life after death that are reflected in cemeteries and funerary practices.

The final contribution to this volume, by Tobias Lang, examines the situation and the role of the Druze in the different nation states of Syria, Israel and Lebanon from the vantage point of political science. Lang argues that the situation of the Druze communities in all three states is vastly different and mainly depends on demographic factors, collective memories, leadership and especially on each country's specific political system. He draws on both a systematic evaluation of existing specialist literature and media reports and on data he has personally gathered in interviews with political protagonists.

The reader ends with some brief final comments by the editor that raise the question of the extent to which "speaking" children and the broader 
cosmological embeddings of the phenomenon are helpful for transcending nation-state borders, at least mentally, and for coping with day-to-day life.

Taken as a whole, this volume seeks to contextualise the Druze conception of "speaking" children and reincarnation along five different dimensions: (a) epistemological foundations of personal identity, (b) constructions of families and kinship, (c) ethnic-religious demarcations and group coherence, (d) metaphysical and cosmological constructions and (e) nation-state contexts and recent challenges. The contributions vary in their thematic scope and have been produced by researchers working in multiple academic disciplines. This has naturally led to a somewhat heterogeneous collection of texts, especially given the varied personal and regional backgrounds of individual contributors. The transliteration or transcription of Arabic follows the respective authors' own specific disciplinary or regional standards. They have been edited in this reader with an eye to the International Journal of Middle East Studies (IJMES) guidelines but have not been meticulously standardised. Commonly known Arabic place names and personal names are spelled as they appear in English-speaking countries or as standard Roman-script spellings in the relevant locations. As for the rendering of Arabic idioms and technical terms, translations into English (unless otherwise indicated) were provided by the authors themselves.

Substantial parts of these contributions were first presented at a two-day workshop on "Reincarnation and Personal Identity in the Middle East", which was held at the Austrian Academy of Sciences (Österreichische Akademie der Wissenschaften, OeAW) in Vienna from 30 November to 1 December 2017 and was well-attended by leading international researchers. Gratitude is due to all participants at this workshop for the exceptionally fertile discussions that took place and the valuable input that was offered, and I would like to extend special thanks here to those colleagues whose contributions could not subsequently be included in this reader for one reason or another - Christopher C. French, Erlendur Haraldsson († 2020), Maria Kastrinou, Stephan Procházka, Gisela Procházka-Eisl and Gerald Sack.

The Austrian Science Fund (FWF) stand-alone project P28736 "Local Conceptions of Reincarnation among the Druzes in the Middle East" (www. taqammus.at) has provided institutional and financial support for this book publication. This project began on the initiative of Gebhard Fartacek and Lorenz Nigst in April 2016 at the Phonogrammarchiv of the Austrian Academy of Sciences (OeAW), an institution that has now been producing and archiving ethnographic audio recordings and developing innovative field research 
methods for 120 years. I am deeply grateful to everybody who has worked on this research project and especially to Lorenz Nigst for his involvement prior to the initial funding application and his three years of work on the project as a postdoc employed at the Phonogrammarchiv. He participated in the initial generation of hypotheses and in the project's first two fieldwork phases (Lebanon 2016 and Israel 2017) and was subsequently involved in important tasks such as organising the 2017 workshop and preparing this book publication. I am also very grateful to the early career researcher Hanna Vettori, who worked parttime on this project and assisted with archiving interviews and with organisational matters.

I would like to express my special thanks to social anthropologist Melanie Sindelar, whose research focuses on art-anthropological themes in the Middle East and who held a post-doctoral position for a short period of time during the final phase of the FWF project in question. She played a significant role in the run-up to publishing this book, especially regarding translation matters and other editorial challenges.

The dedication of Amjad Khaboura, Safwan Ashoufi and Wansa Nasrallah also deserves special mention. All three are Druze refugees, and their involvement added a participatory research dimension to this project. The emic explanatory models of these project colleagues and their specialist training in the areas of conflict management and psychotherapy represented a valuable resource for interpreting the interviews that were conducted in the course of the research project and have been archived at the OeAW Phonogrammarchiv. All three also conducted interviews on our research themes with Syrian Druze individuals - in some cases using modern digital communication technologies.

The production of this book was a challenging process for all involved - and at this point, I would like to offer my warmest thanks to all the contributing authors, especially Eléonore Armanet, Nour Farra Haddad, Tobias Lang, Lorenz Nigst and Salmah Samaha, for their colossal commitment, their indefatigable dedication and their enduring patience. In addition, I would like to explicitly thank Stephan Procházka for reviewing the book manuscript; as an Islamic studies scholar and philologist, he provided crucial input that shaped this book into its present form. Finally, for English-language editing and translation work in the context of this book publication, I would like to thank - in addition to Melanie Sindelar - Kate Sotejeff-Wilson and Sarah Swift for their outstanding efforts. In institutional terms, gratitude is due to the Austrian Science Fund (FWF) for its courageous funding of projects that presented geopolitical challenges and broke new ground in terms of methodology. I am profoundly grateful to the Presiding Committee of the Austrian Academy of Sciences for their initiative 
enabling refugees to undertake internships at the OeAW. The contributions of Safwan Ashoufi and Wansa Nassrallah to the project were funded by this initiative, which also sent out an important socio-political signal. Finally, but not least importantly, I wish to thank all my gracious and competent colleagues at the OeAW Phonogrammarchiv, and especially its head, Kerstin Klenke, who was able to advise me on the production of this publication.

Gebhard Fartacek, Vienna, February 2021 


\section{Gebhard Fartacek}

\section{Ethnographic Insights: Narratives Dealing with Previous Life Memories Among the Druze}

\section{Preliminary epistemological and methodological remarks}

The interview excerpts reproduced below have been taken from interviews conducted in the course of empirical data collection for the FWF stand-alone project P28736, "Local Conceptions of Reincarnation among the Druzes in the Middle East".

The research design for this project adopts a constructivist research approach. ${ }^{1}$ This means that the collection and analysis of the data are not focused on the question of whether people have in fact been "genuinely" reincarnated (from an objective point of view). Instead, the research explores the role played by conceptions of the transmigration of souls and rebirth in the daily lives of the Druze population and the extent to which such conceptions appear viable ${ }^{2}$ within Druze communities.

For methodological reasons, this research project draws on narrative interview techniques. Interviewers generally sought to strike up an open-ended hypothesisgenerating dialogue on the complex of issues surrounding taqammus and nutq with the interview partners. The scope of the interviews encompassed both general reflections on the nature of reincarnation (taqammus) and the reconstruction of specific cases involving individuals with previous life memories who spoke about their past lives and went on to find their previous-life families ('amaliyat

1 Constructivist epistemology can be clearly distinguished from so-called realist or "rationalist" positions that consider the ability to reconstruct a reality that exists independently of the observer as the most important epistemological capability of humans. The core thesis of constructivist epistemology, in contrast, holds that subjects generate their own realities rather than merely representing reality. For constructivists, reality is a product of human thought and not merely a prerequisite for it. What is "radical" about constructivist theory is its assertion that "objective reality" is not directly accessible to us: Our perceptive abilities are limited (we can be misled by optical and auditory illusions, for example), and our subjective perspective means that we are guided by our own interests as we interpret our findings. While constructivism does not reject the existence of reality, it posits that we can only recognise our own subjective reality that "triggers something within us" (see Fartacek 2010: 28-35; for more on the wider discussion, see Schmidt 1997, 2003).

2 On the concept of viability, which relates to actions and thoughts and demands “adaptation”, see Glasersfeld (1997: 193). 
an-nutq). Interviewers were guided by the episodic interview method outlined by Uwe Flick. ${ }^{3}$ Two different kinds of knowledge were differentiated in the collection and recording of data: semantic knowledge and narrative-episodic knowledge. ${ }^{4}$ General reflections on the point or pointlessness of believing in reincarnation (taqammus) elicited semantic knowledge from interview partners, but interviewees drew on and revealed their narrative-episodic knowledge when describing specific nutq cases that had arisen in their own social environments. The relationship between both of these different forms of knowledge is complementary, and the research process was designed to gather and analyse both forms. ${ }^{5}$

In the interview excerpts reproduced below, the narrative-episodic knowledge of the interview partners is foregrounded. The nutq cases referenced had affected the interview partners emotionally and were described with considerable

3 See Flick (2014: 273-274): "The starting point for the episodic interview [. . . is the assumption that subjects' experiences of a certain domain are stored and remembered in forms of narrative-episodic and semantic knowledge. Whereas episodic knowledge is organised closer to experiences and linked to concrete situations and circumstances, semantic knowledge is based on concepts, assumptions and relations which are abstract from these and generalised. For the former, the course of the situation within its context is the main unit around which knowledge is organised. In the latter, concepts and their relation to each other are the central units". The interviewing method developed by Uwe Flick aims to capture both of these forms of knowledge. While narrative interviewing captures the episodic knowledge of interview partners and permits its analysis, reflections on semantic knowledge are typically sparked by researchers asking specific, targeted questions. Uwe Flick's model combining both types of interviewing does not simply aim to save time by allowing researchers to jump pragmatically between distinct types of data, "narratives" and "answers". It serves, rather, to uncover systematic links between forms of knowledge that come to light when both types of data are looked at in tandem (Flick 2014: 274).

4 For more on the distinction between both types of knowledge, see Robinson and Clore (2002: 199): "Episodic knowledge is experiential in nature and inextricably bound with details of time and place [...]. Semantic knowledge, by contrast, is conceptual in nature and decontextualised - that is, divorced from details of time and place [...]". Both forms of knowledge play vastly different roles in the context of autobiographical memories, as Robinson and Clore demonstrate conclusively in their psychological study.

5 See Fartacek (2017: 29-33) for more on the value added by distinguishing between these distinct forms of knowledge and categorising material that has been gathered accordingly. It appears that the authenticity attributed to nutq cases by interview partners must be appraised differently for cases mentioned by interview partners purely to illustrate points they were making (drawing on their semantic knowledge) vis-à-vis cases interview partners were strongly involved in personally and narrated using episodicnarrative knowledge. This is explored further towards the end of this contribution. 
empathy during the interviews. To ensure the interview passages included in this book constitute a representative selection, the interviewees include both people with personal memories of a previous life who have been recognised as a nattiq or nàtiqa and relatives (sons, fathers, brothers etc.) of such "speakers". In addition, some cases are described from "further away" by interviewees with less direct connections to the people involved and more of an outsider perspective. Our interview partners are Druze men and women from North Israel, Lebanon and Syria - including some who have come to Austria in recent years as refugees and found a new home here. The selection of interview excerpts also seeks to provide a representative overview of how cases of nutq are narrated and to make aspects that are seen as important and addressed in virtually all narratives visible (elements of plot construction, cf. Straub 1998). The selection also sheds light on the wide variety of approaches towards "speaking" children that exist and may be pursued in different contexts: children can be silenced by their present families or rejected by their previous families, but they can also be euphorically received by their previous families and reintegrated into family life. Specific kinship ties can be constituted by nutq cases, and they are highly significant for the cohesion of the Druze community, at least at the level of the collective discursive construction of reality. These excerpts are followed by some thoughts and working hypotheses.

The passages reproduced below have been taken from a more substantial collection of some 40 recorded interviews that have been archived, together with summary translations into German and content summaries, in the OeAW Phonogrammarchiv. Details of the contexts in which individual interviews took place (the location, the people present, the languages spoken) are given in footnotes. As some of the autobiographical narratives shared with us contain very personal details, the names of interview partners and of all persons mentioned in interviews have been changed. The audio recordings are stored on long-term storage media at the OeAW Phonogrammarchiv. To protect the privacy of the interview partners, they have been placed under embargo until 2099; after that date, they will be at the disposal of future generations of researchers. ${ }^{6}$

6 Many people contributed to ensuring that these interviews could take place. The greatest thanks are due to the interview partners, who generously shared their life stories with us, along with their views on the connections between taqammuṣ, nutq and constructions of identity linked to them. Special thanks are also due to local specialists and fellow researchers, who guided us to "speakers" or their relatives, especially Joe N., who willingly shared numerous highly relevant contacts in northern Israel with us. The social anthropologist Nour Farra Haddad, who has also made a contribution of her own to this volume, passed valuable contacts to interview partners in Lebanon onto us. I also wish to expressly thank the colleagues who were involved 


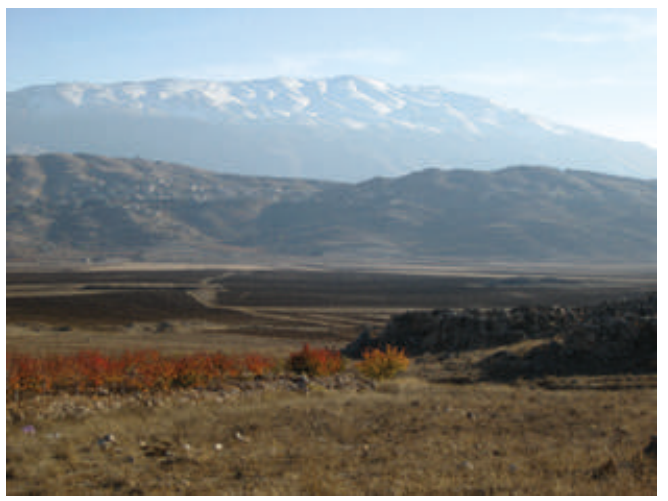

Fig. 2: Contested by nation states: The Hermon mountain range (jabal ash-shaykh) in the midst of Druze settlement areas. Photo taken in the southern Biqā plain, Lebanon. Photo: Gebhard Fartacek, 2016.

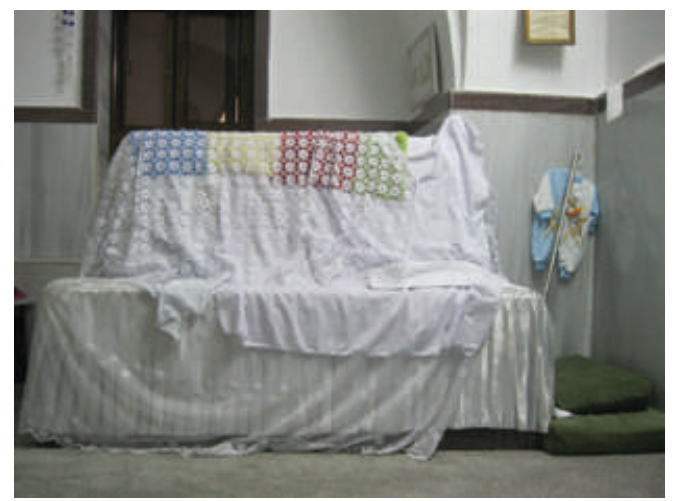

Fig. 3: The tomb of Sitt Sha'wāna: A Druze pilgrimage site in the Golan Heights. Photo: Gebhard Fartacek, 2017.

in the project as interns or student assistants employed within the scope of the OeAW internships programme for refugees. Safwan Ashoufi and Wansa Nasrallah, who both have a Druze background themselves, organised numerous interviews and in some cases also conducted interviews themselves. This is also true for Amjad Khaboura, whose contribution was financed from project funds. (For an account considering methodological implications of participatory research approaches and reflecting on personal experiences, see Fartacek 2020). Special thanks are also due to Lorenz Nigst and Hanna Vettori, whose work was also funded through the FWF project P28736. 


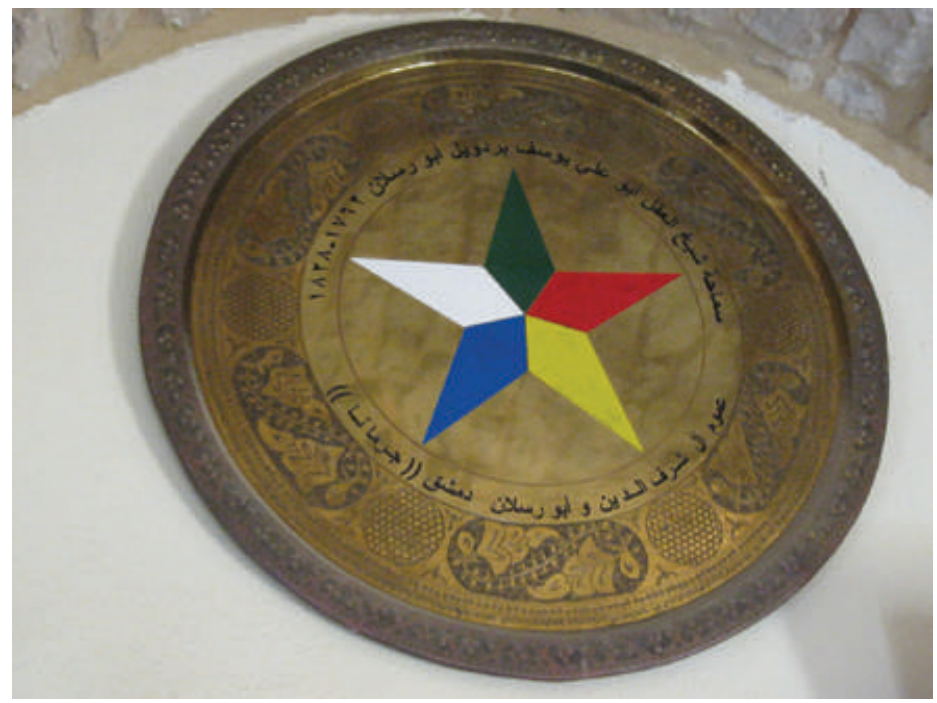

Fig. 4: The Druze star in the typical five-colour combination. Votive offering inside the burial chamber of a pilgrimage site, Shūf mountains, Lebanon. Photo: Gebhard Fartacek, 2016.

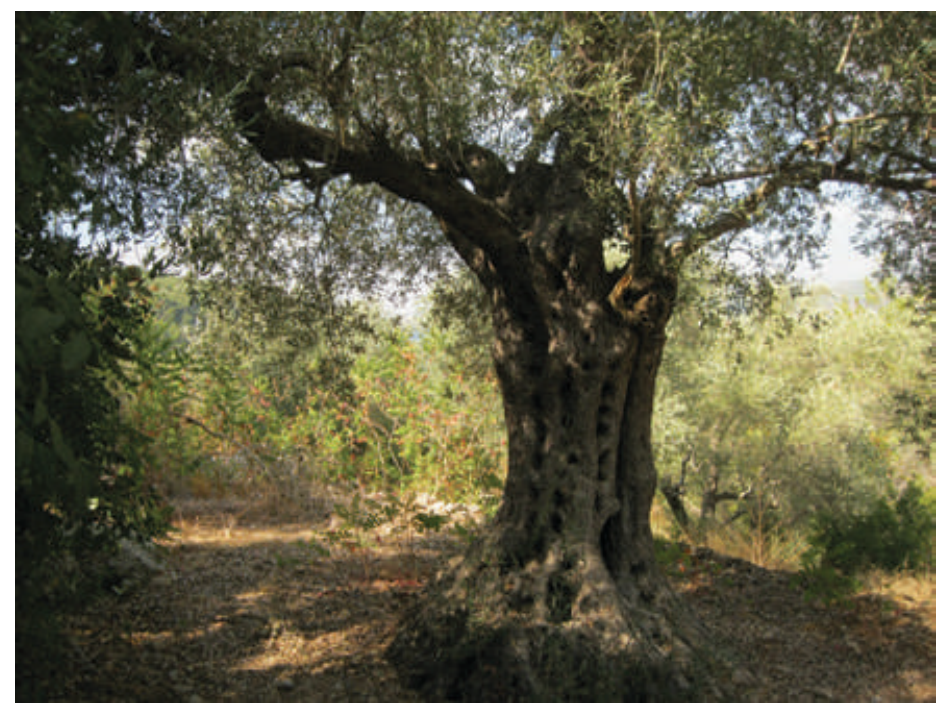

Fig. 5: An olive tree deemed sacred at a Druze pilgrimage site in the Shūf mountains, Lebanon. Photo: Gebhard Fartacek, 2016. 


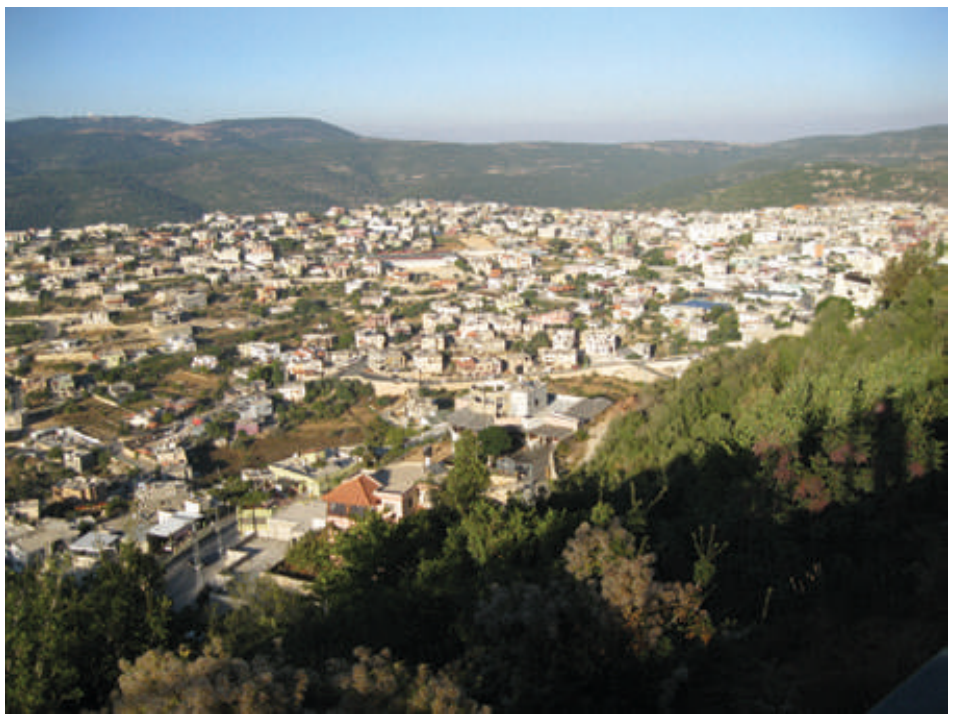

Fig. 6: The Druze settlement Bayt Jann, the secret capital in northern Israel. Photo: Gebhard Fartacek, 2018.

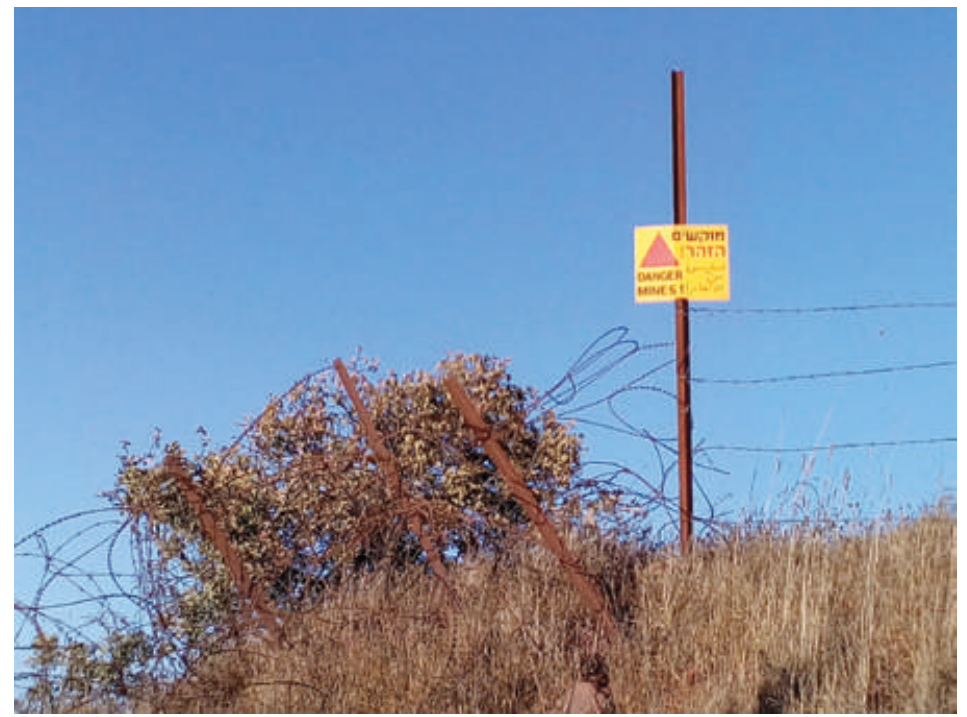

Fig. 7: Divided by minefields and barbed wire: Druze settlement areas of the Golan Heights. Photo: Gebhard Fartacek, 2017. 


\section{Cases of "speaking" children: Descriptions given by those affected}

\section{CASE A: | "And I suddenly recognised the tomb keeper as my cousin from my previous life" - A nätiq describes his life between two generations}

The first case presented here was narrated to us by Nabil*, a Druze man in his forties from the area around Yarkā in northern Israel. The interview partner described finding his previous family during a pilgrimage to Hurfaysh, a Druze town some $50 \mathrm{~km}$ east of Yarkā with around 7,000 inhabitants in what is now a frontier region close to the Lebanese border. He described similarities and seemingly coincidental connections between his present life and his previous life, which had ended tragically, he told us, when he was fatally shot. ${ }^{7}$

I was four or five years old. I saw episodes from my previous life again and again in my dreams - and I told my mother that I'm not from this place here [.. .].

The neighbours had a lorry. I was fascinated by this lorry as a child. I wanted to climb into it whenever I could because I had possessed just such a lorry myself in my previous life.

The interview partner described how he gradually saw his previous life unfolding in front of him when he was a small child: I knew that I was called Wa'il F.* and that I had been murdered!

The interview partner told us that his mother began to ask him questions about where he was from, for instance. And he told her that he was sure that he had lived in Hurfaysh before.

And so the family (the interview partner, his parents and an aunt) began their search. First, they made their way to a famous Druze pilgrimage site, the hilltop tomb of Nabi Sabalān high above the village of Hurfaysh. When they arrived there, the interview partner's mother asked a female tomb keeper whether she could tell her anything about a young man called Wa'il F.* who had been murdered six years previously. The tomb keeper, an older woman,

7 The interview was conducted in July 2018 in Arabic (the local dialect). It took place in Yarkā in the house of a mutual friend. Apart from the interview partner, the mutual friend was present, as were some of his family members for part of the time. Gebhard Fartacek and Joe N., who had put us in touch with the interview partner, were also present. The audio recording has been archived in the OeAW Phonogrammarchiv with assistance from Hanna Vettori (Signature: 20180706.G002). The names of the interview partner and all of the people mentioned in the interview have been changed (and marked with an asterisk) to preserve their anonymity - here and in the remaining excerpted interviews in this volume. 
answered in the affirmative: Yes, she did know a man who had been murdered six years ago and was called Wa'il $\mathrm{F}^{*}$ !

The interview partner gave us an intensely emotional description of how he had recognised the tomb keeper as his cousin from his previous life at this very moment. She finally hugged him and began to cry!

They then set off on foot together. His previous house was about $3 \mathrm{~km}$ from the Nabi Sabalān shrine - and he found the way to the house unaided, intuitively guided by his memories.

We knocked on the door of my [previous] house, but there was no answer. Then we went to the house of my [previous] brother Nazim* directly opposite, just slightly below the main street. Nazim* is married to a Lebanese woman; she opened the door, looked me up and down and asked me who I was. I stepped into the house, alone, and told her that I was Wa'il*. Then my nuṭ was "examined". They showed me photographs and I had to recognise myself in them. They told me to tell them more about my previous life. I told them that I had a son called Nabil ${ }^{\star}$ and was married to a very beautiful woman.

What surprised my examiners most - besides a striking scar on my face that I had already had in my previous life - were the correspondences between the given names of certain family members. My beloved son from my previous life was called Nabil ${ }^{*}$ - exactly the same name given to me by my parents in this life! After my death, my wife married my cousin, who looked after my children and is named Hasan*. Hasan*, in turn, is also the name of my father - in this life!

My father from my previous life also examined me by asking a question. He wanted me to tell him about a special experience we had had together. I told him that we had once hunted hares together - and I was able to describe all the details to him.

Later, the interview partner turned to the topic of his death, which he linked indirectly to the historically proven Ma'alūt massacre ${ }^{8}$ : It was a chaotic period, the interview partner told us. He had been working as a lorry driver at the time, and he had - legally - possessed a pistol. On the evening of his death, he had told his then wife Rima* that he just wanted to make a quick detour. He had his gun with him. On his way, he picked up two Israeli soldiers, a man and a woman. The pistol was already loaded. The young female soldier was called

8 This incident took place in 1974. Over a hundred Israeli school pupils were taken hostage by Palestinian militants who entered Israel from Lebanon, and more than 25 people were killed when the building was subsequently stormed by an Israeli special forces unit. See: https://en.wikipedia.org/wiki/Ma\%27alot_massacre (accessed on 15 June 2020). 
Joha*. As they were passing a food stall, he stopped. They wanted to buy something quickly and then get moving again. When he came back, he saw that Joha $^{\star}$ was playing with his pistol. He warned her and right at that moment, a shot was discharged and the bullet hit him in the leg. The two soldiers fled and he bled to death, dying at 04:30 in the morning. Help came too late for him.

The interview partner explained that the soldier, Joha*, had not intended to kill him and that the shot had been discharged spontaneously; as far as he was aware, she had been convicted only of failure to provide assistance and had only had to serve two years in prison.

The interview partner subsequently described his close relationship with his previous family in detail. As a child, he had visited his previous family regularly, and his previous mother had also come to visit his present family many times. At the beginning, especially, these visits had been very challenging emotionally. Both his mother and his son (from his previous life) had cried a lot, as they were extremely attached to him and his death had left a void in the family. But the situation had gradually become more normal; his return (as a reborn child) restored calm to his previous family.

As a child, he lived in two worlds, in two realities: one in Yarkā and a different one in Hurfaysh. Reality in Hurfaysh had initially been more like a dream, but it gradually proved to be true and finally became real. Only as he came closer to adulthood, the interview partner reported, did he start to arrive more in his current life. His life today was, he told us, almost entirely friction-free.

The interview partner underscored several times that he gets on well with Hasan $^{*}$, the present husband of his wife from his previous life and adoptive father of his son from his previous life. Hasan* had brought his son up very well and "been like a real father" to him, but he had also been pleased, as an adoptive father, that the opportunity had arisen for his son to keep in touch with his "biological father".

The interview partner radiated pleasure and pride as he told us that he had occupied the role of the father of the groom at the wedding of his (previous) son. When his (previous) son's wife in turn gave birth to a son, they had initially been unsure whether they should call the boy Hasan* after the Hasan* who had adopted the father of the baby or Wa'il*, the interview partner's name in his previous life. Hasan ${ }^{*}$ signalled his agreement with his adoptive grandson being called Wa'il*. For the interview partner, this was a clear sign that Hasan* was not in any way jealous of his position.

Further on in the conversation, the interview partner repeatedly stressed positive aspects of nutq and commented that finding his previous family again had greatly enriched his life. As a child, he had always felt a compulsion to 
pursue his nuṭ story; negative consequences would surely have resulted, he felt, if he had tried to suppress this need.

The interview partner also described the case of his (other) brother from his previous life and told us that he - likewise - had been murdered and come back as a reborn person; the two reborn brothers had attended the funeral of their (previous) mother together only recently.

The interview partner concluded that the principle of rebirth, taqammus, reinforces solidarity among the Druze: Taqammus binds the community together, as encounters with family members from past lives can occur at any time. This results in people treating others within the faith with affection. It can always be the case that the person opposite you was your mother, your father, your brother... in your past life!

\section{CASE B: | "My father liked his ex-parents and his ex-family more than our family here" - The son of a nätiq describes a kinship relationship established across generations}

A well-off and well-educated Druze man aged around 50 shared his father's life story with us - a story he had absorbed from close quarters and one that has had lasting consequences for his own life. This case was set in Bayt Jann, a town of some 12,000 inhabitants in the mountainous countryside of Upper Galilee, which is sometimes described as the social epicentre of the Druze in northern Israel precisely because of its rather remote topography (cf. Fig. 6). ${ }^{9}$

My father was born in 1934, here in Bayt Jann. His parents were Druze, too. In the first years of his life, when he was about three or four years old, he started to tell my grandmother that she was not his mother. He mentioned the name of his mother from his previous life. His parents tried to find out where he had lived before. He told them that he was not from Bayt Jann, but from Maghār near Tiberias in northern Israel. It's about $20 \mathrm{~km}$ from here.

The interview partner told us that his father, now deceased, was called Hatim $^{\star}$ and had been called Wahib ${ }^{*}$ in his previous life. He explained that $n u t q$ cases must always be backed up with evidence, the reincarnation also depends

9 The interview was conducted (mostly in English, but partly also in Arabic) in the interview partner's private dwelling in August 2017. Besides the interview partner, Gebhard Fartacek and Lorenz Nigst were present. The audio recording has been archived in the OeAW Phonogrammarchiv with assistance from Hanna Vettori (Signature: 20170830.G001). A year later, Gebhard Fartacek conducted a follow-up interview (see below). 
on how you can prove it, and that a previous-life family always examines cases comprehensively: "Speaking" children are quizzed on details about family members, particularities and secrets as if they were facing a judge demanding evidence in court.

The interview partner continued with his father's story, saying that his father had asked his mother to bring him to the village of Maghār. He had wanted to be brought to the first house in the village so he could find the way to his house from his previous life from that point. He was three or four years old then. They brought him to Maghār, the interview partner told us, and when he got there, he announced that he knew the way to his house. He started walking and brought his parents to his house from his previous life after walking $4 \mathrm{~km}$. It was an old house in the old part of Maghār. He knocked on the door: minn hün - who is here? His brother (from his previous life) and his brother's wife were at home and opened the door. His brother had soon invited people to come round and told them that a boy claiming to have been Wahib* in his previous life was there. They asked him how he had died in his previous life. That is the best form of proof one can give to show that one has been reincarnated, the interview partner told us. His father had answered that they had been in the fields and that his father had sent him home with his eldest brother. As he was riding home on a horse, they reached a spring and a big snake there struck at the horse's leg, causing it to spook and spin around in circles. He fell off the horse and the snake bit him. That was what the interview partner's father had remembered. He had also been able to recall seeing his elder brother crying and seeing himself lifted back onto the horse and brought home, where he had felt his soul leaving his body soon after they reached the house. That was the story of his death.

The interview partner narrated how the examination had continued. His father had been asked to point to various family members who were present (Where is your mother?), and he had identified his mother and his sisters successfully.

He had gone on to share a secret with them (Before I died, when I was a child, I used to play with toys and hide them in a secret place) and to guide those who were present to the hiding place - where the toys were still lying in a trench. At that point, the family members had begun to cry. The interview partner's father had definitively proven his story, as the interview partner related: This is his story. Really, he proved it! 
The two families had, we were told, gone on to become a single family and still enjoyed an excellent relationship at the present time. They visit each other on feast days and for weddings, but also without waiting for special occasions. The interview partner repeatedly underscored the close nature of his father's relationship to his family from his previous life: The thing that I want to let you know is that my father likes the ex-parents and the ex-family more than the family here. The relationship between the ex-family and him was a deeply warm relationship, which is really a proof that the thing is right. He was feeling that I belong to this family. I need this family. I like this family. I want to be with them. I have to share with them all the ceremonies [...]. This is the story of my father!

The interview partner then gave an immensely powerful and emotional description of how his father's close relationship with his previous family had also been handed down to himself and to other family members - so that it still existed now even though his father, the connecting link between the families, had since died:

I feel that my cousins there [in Maghār] are really the relatives of mine! [. . .] They are kissing me from here and they are hugging me. Kisses which are forbidden you know. I say this is from God. This makes you first of all believe.

The interview partner went on to explain in various ways that the kinship ties to his father's previous family had now been passed down to the offspring of both families. It was a warm, good and open relationship, he said, remarking that the families invite each other for visits on feast days and important social occasions as is usual among relatives. He felt a strong emotional connection to these relatives, he commented, but also a certain obligation to visit them from time to time and to treat them like family members. He did not doubt or critically interrogate the kinship relationship; he simply felt that he belonged to this extended family.

As the interview went on, the interview partner described two more nutq cases from his own social sphere. In both cases, he reported that the children involved speak a different language (English and Hindi), as they had lived in countries where those languages were spoken before being ripped from their lives there suddenly and, as it were, bringing their respective native languages into their present lives along with them.

In general, the interview partner concluded that kinship ties created through nutq are a gift of God and that it was good for "speaking" children to find their previous families (again). 
A year later, in July 2018, a further interview took place..$^{10}$ In his conversation with me, the interview partner underlined his positive perspective one more time: If everybody believed in the principle of reincarnation, all of humanity could coexist peacefully without wars, borders, nationalism or radicalism. Reincarnation, the interview partner commented, leads to equality.

I was interested in discovering whether the interview partner thought that children with memories of a previous life should always be supported in their "speaking" and their efforts to find their previous families - or whether cases could also arise in which he believed it would be better to try to get children to forget their stories. The interview partner initially responded that it was not good for parents to try to prevent their children from remembering past lives. Quite the opposite was the case: I think we must do that, we must encourage them to speak about it in order to release his frustrations from inside, [... and we have to] take him to the other family in order to create another social net, which is very strong and very good. Besides, I think it's really very amazing and good to have two families.

He went on to elaborate: This is the marvellous, the good, the exciting thing from the reincarnation. People that you are, did not know, during this things, this situations, you become one family, brothers and sisters. It is very exciting.

But when I asked again, the interview partner added a qualifier to his statement that the topic should always be dealt with as openly as possible. Yes, there were certain cases, he commented, where it was "safer" for the child in question not to speak of what had transpired. And he mentioned a case in which the murderers of a deceased and now reincarnated person were still freely walking around the local area:

It happened here in Bayt Jann. One man called Abu Saleh*. He was killed. They shot him here. He said they shot him three times here. After that they took him and buried him in one place, in the fields of Bayt Jann, far away from the village. This Abu Saleh*, his soul was transmitted to another child, from another family, which is called [...]. I didn't know the name of the child. I know the child. $I$ know his father. His father has died. His mother is a relative of mine. When this child became three or three and a half, he starts speaking that $X$ and $Y$ and $Z$ they shot me, they put me in, like this, in this șandūq [box] and they took me in the fields of Bayt Jann and they buried me. You know [. . .] his mother was afraid that

10 This interview was again conducted in the private dwelling house of the interview partner in a mixture of English and Arabic. The interview partner and Gebhard Fartacek were present. The audio recording has been archived in the OeAW Phonogrammarchiv with assistance from Hanna Vettori (Signature: 20180709.G001). 
if those people, who killed him, know this generation they can kill him. So that she asked him not to speak about that because of this bad situation.

In such situations, the interview partner commented, it was better for the $n \bar{a} t i q$ to remain silent about what had taken place. Why? Simply because the child is in danger!

In the specific case in question, the mother had taught her child not to tell anybody what had happened. And when the little boy sees these people (his murderers), he has instructions to greet them, but to say nothing further and not to talk to them. They are bigger and stronger than he is. The gist of what the interview partner told us was that the boy was still a small child and could be eliminated by the murderers at any time.

\section{CASE C: | "You are my friend, not my father" - A nätiq speaks about his advantageous life in an extended family}

The case described below demonstrates very tangibly that kinship ties constituted through nutq cases are sometimes not only conceived of but also - in the truest sense of the word - lived and that they can (as an ethnosociologist would put it) also manifest in the post-nuptial residence form of a nattiq and his families. A family father from the wider region around Yarkā was reborn in a neighbouring locality that was locked in a feud with his former home locality. He already made his way to his previous family as a four-year-old child; a strong sense of having two families stayed with him throughout his childhood and adolescence - and when he was 20 years old and got married, his previous-life family made him a present of building land right next to their house. He thus built his house right next to the house of his previous family and now lives next door to his previous-life family and their offspring with his wife and child. ${ }^{11}$

The interview partner began outlining his biography with a description of his previous life: His name had been $\mathrm{Na}^{\prime} \mathrm{im}$ Mahmud ash-Shufi and he came from Jülis. He had died at the age of 28 during his military service in the Israeli army. He mentioned a close friend called Basil ${ }^{\star}$ who had been in the army at the same time as him and had become his father in his present life. As the interview partner explained, he had not been killed but died in an accident. He had been given a few days leave from the front to celebrate the upcoming holiday of

11 The interview was conducted in July 2018 in the private dwelling of the interview partner in Arabic (the local dialect). Gebhard Fartacek, Joe N. and the interview partner were present. The audio recording was archived in the OeAW Phonogrammarchiv with assistance from Hanna Vettori (Signature: 20180706.G003). 
Eid al-Adha with his family, and on the day of his death, he was with his wife, Mayan ash-Shufi ${ }^{\star}$ and they were running some errands together to get ready for the holidays.

The interview partner began to recount, scene by scene, how the accident had unfolded. He had been sitting in his car with his wife and children and a friend of his called Yazan*. His army weapon was in the car boot. Cars back then - this was in 1984 - had a hook on the inside of the boot that could be used to lock it. The gun had become caught on some webbing and stuck in this lock - it was loaded - he wanted to free it, but somehow got his finger caught on the trigger - a shot was discharged, and the bullet went directly through his skull, injuring him severely. He was close to an army base and the emergency services were alerted quickly. A helicopter was summoned to bring him to the nearest hospital. Immediately before his death, he asked his wife to look after the children. His wife was six months pregnant at the time. He was still in the helicopter when he died, he told us.

His friend Yazan* was now a suspect, as he had been present when the fatal shot was fired. His wife had also been at the scene, but she had been busy with the children at the instant the accident occurred and had not witnessed it directly.

At the moment of his death, the interview partner had been reborn at the side of his friend (and present father) in Yarkā,... u khalaqət bi Yarkā jamb Basil $^{*}$.

When I asked whether the moment of death and the moment of birth were a complete match, the interview partner answered in the affirmative and added the following explanation: al-jism mät bass ar-rūh mā-mätat-sh. tala'at min $\bar{a} d a m$ li-l-ädam - the body died but the spirit did not die. It went from person to person.

The interview partner reported that he had started to speak and to express himself at the age of three. One day, he said antā șahbì mish bùùì! - You are my friend and not my father! to his father. As a small boy, he was already able to remember his previous life very precisely.

When he was asked where he was from, he answered: ana min balad ashshaykh, literally: I come from the village of the shaykh - the locality of Jülis, in other words, where the spiritual leader of the Israeli Druze resides, currently Shaykh Muwaffaq Tarif, but at that point in time still his grandfather.

The interview partner described some memories from his previous life: A picture of the Shaykh from the Tarif family in his house, a repair to a car belonging to Basil ${ }^{*}$ (then his friend and now his father) and the given names of an aunt and his cousin in his previous life. He told us about a game of football in 1983 
that had triggered severe violence between Jūlis and Yarkā and seen a man from his previous family fatally stabbed. Taking part in a subsequent retaliatory attack had led to him being caught throwing grenades (nobody was hurt in the incident, but considerable damage resulted) and imprisoned for six months. Basil $^{\star}$ had visited him in prison and brought him milk in a tarboosh (tarbüsh). The interview partner described the conflicts between both localities and his own involvement in them: He had hidden contraband arms and used an Israeli army vehicle to transport them. He hid some of the weapons in a trench under a gas tank - nobody would suspect that there was an arms dump there. He deposited the remaining weapons in a hiding place under the stairs of his house and hid the key to this space behind a loose tile in the attic.

The interview partner described the day he found his previous family as his present-life father Basil ${ }^{\star}$ had experienced it. When Basil's* three-year-old son told him that he was not his father, but a friend, Basil ${ }^{\star}$ decided to drive wherever his son wanted to go. Both the interview partner's parents drove to Jülis together with their young child. In front of the former home of the nattiq, they encountered Zahi* ${ }^{\star}$ a friend the child immediately recognised from his previous life and called by name. The boy pointed out his former house. They entered the house and met his wife from his previous life. The boy said hayy Mayan ${ }^{*}$ - this is Mayan* ${ }^{*}$ As the interview partner described the scene to us, he had then gone on to brusquely command his father to go home and leave him alone in his house with his (previous) wife. His wife hugged him! Then all of his relatives (from his previous life) gathered, and he was able to recognise and name them all, including their spouses and children. Questions were asked to examine him further, and he was able to answer them all correctly. Among other topics, he mentioned a tree he had planted for his wife and child. Before the family took their leave and drove home, he supplied further decisive evidence by guiding those who were present to the hiding place of the key in the attic, showing them the weapons hidden under the stairs, and guiding them to the trench below the gas tank. They were all amazed - they had known nothing about arms stored in and around the house.

The weapons were subsequently returned to the Israeli army. He is still close to his friends from his previous life - he invited them all to his wedding in 2012. Right up to the present day, he feels that he belongs in both lives: anā issa ' $\bar{a} y s h$ fi-jīlayn [...] anā bi-hayy l-marhala mā-mutət-sh bass al-jasad mät - I live in two generations at the moment [.. . I didn't die in that phase, only my body died.

The interview partner recounted that his "speaking" had also exonerated his friend Yazan*. As Yazan* had been next to him when the fatal shot was discharged, he had been confronted with accusations of murder in the 
aftermath. In her panic, his previous wife Mayan* had also initially accused Yazan* of having fired the shot. Yazan* had been arrested and briefly detained on remand. While he was acquitted, lingering doubts as to his innocence had remained. As the interview partner narrated compellingly, this was one of the first questions he was asked when he began to "speak": Did you die a natural death or were you killed? Was it Yazan* who shot you? The interview partner was able to remember how the accident had played out very precisely and knew that he had died through his own fault. He was able to clear up the matter: an $\bar{a}$ mutot bi-l-ghalat - I died by mistake (and was not murdered)! His friend Yazan* has been free from all suspicion since then and remains a close friend.

The interview partner gives the impression of being blissfully contented when he refers to living "in two generations". He was beaming broadly as he described his life in his current house, right next to his old house and surrounded by cousins from his previous life. He feels part of an extended family: Not much has changed! His previous wife Mayan* and his current wife Safa* are, he reported, exceptionally close friends. When his present wife gave birth to his children, his previous wife Mayan* had been as pleased as if one of her biological daughters had borne children. And his children from his previous life had asked him to "lead the bride" at their weddings. The role of leading the bride is normally performed by the father of the bride, the interview partner commented. His children from his previous life had also been very actively involved at his own wedding in this present life!

Joe N., the acquaintance of the interview partner who was himself from the area and was also present at the interview, commented with a grin that people from Jülis had organised a wedding for the nattiq as they would organise one for a true son of the village because he belonged to them and had been reborn again; they would not have taken such trouble for a "stranger" [and one from Yarkā, of all places]!

This nuṭ case with its emphasis on mutual harmony must presumably be seen within the wider context of the previous feuds (surrounding the football game) between Yarkā and Jūlis and the animosities between both areas that persist.

Interestingly, the (improved?) relationships between the two localities seem to have been continued in at least one more nutq case. As the interview partner disclosed in the course of the conversation, his five-year-old son (in his present life) also has memories of a previous life: He had been a school principal in Yarkā (!) who had died five years beforehand. 
“... And my son 'speaks' too!"

\section{CASE D:}

In the interview ${ }^{12}$ with the "speaking" child, who was brought into the room immediately, it was noticeable that the child's father frequently interrupted with corrections. The young boy gave his full name from his previous life, the names of relatives and the school subjects he had taught (Arabic and English). His father reported that he had spoken some English right from when he began to talk and could "remember" English right up to the present. Prompted by his father, the boy began to recite the English alphabet.

During the interview, the son shyly told us about the family's search for and their discovery of the boy's previous family (with many corrections and explanations from his father). The boy had told the family to build him a school where he could teach. In the context of a funeral, the family then encountered the school principal's descendants: The five-year-old boy recognised a house as his previous house as they were passing it, and when they spoke to the people who lived there, it turned out that a person - an older man - had indeed died there at exactly the time when the boy was born. Evidence was supplied, and the contact with the child's previous family was felt to be exceptionally positive, but it had only just begun.

The boy's father (the nattiq at the centre of Case C) appeared visibly relieved by the discovery that his son (the näțiq in Case D) had been a "good person" (ibn haläl) in his previous life.

\section{CASE E: | "Mahmud Abu Amjad", who I was in my last life, died poor. He lived poor and he died poor" - A nätiq as a connection between two feuding clans}

The case described below has its setting a few kilometres north-east of Yarkā in the Druze town of Abū Snān. In this case, too, the interview partner emphasised the positive aspects of "speaking": It was ultimately nutq that had led to reconciliation in a feud that had seethed between two clans for generations. But political rivalries and social inequalities were emphasised more in this interview than in others.

The interview partner, a man of about 50, had something unusual in common with the five-year-old nätiq mentioned above (Case D) who remembered his

12 Interview in July 2018 in Arabic (the local dialect). The audio recording has been archived in the OeAW Phonogrammarchiv (Signature: 20180706.G003|Part 2). 
previous life as a school principal: He, too, had died a natural death as a wise man of mature years. ${ }^{13}$

The interview partner reported that he had been about three years old when he remembered his previous name, Mahmud ${ }^{*},{ }^{14}$ and began to speak about his previous life. Everything had happened automatically: Whenever his mother called him by the name of Ahmad, he had replied that he was called

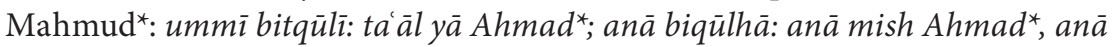
Mahmud*!

The interview partner described how his parents asked him questions: Who is Mahmud*? Where does Mahmud* live? And so on. He took them by the hand and showed them the house. The house of his previous-life family (al-'a' ila assābiqa) is only $100 \mathrm{~m}$ from the house of his present family, the interview partner told us. Both families had lived in the same neighbourhood, but he had hated his present family in his previous life on account of local conflicts.

The interview partner described supplying an entire series of pieces of information so that he would be believed. Even when he was only three and had just begun to speak, it was already obvious that he knew his way around the house of his previous family very well. He showed them the box where he used to hide his valuables in his previous life. He told them about his pistol, which he had hidden in a cranny on his (former) land - they set off to look for it and found it in exactly the location he had described beforehand. He was shown photographs of people, and he could identify and name all of them. As a nätiq, he knew how important the farm had been to him in his previous life, from the land to the dwelling house - he had highly specific memories of every detail, right down to the design of the kitchen: They had not had an "ordinary" kitchen, but a "foreign" one (matbakh ajnabi)). Last but not least, he could also remember how he had died: He had been sitting peacefully on the steps with his grandson next to him. He had already been more than 80 years old at that point, he had had six children, and he had finally died a natural death. In the minute he died, he was born (again), bi-nafs ad-daqiqa tuwuffèt khalafət, as he was able to verify later himself from records kept in the hospital.

13 The interview was held in the private dwelling of the interview partner in July 2018 in Arabic (mostly the local dialect) with occasional explanations in English or German. Gebhard Fartacek, Joe N. and the interview partner were present. The audio recording was archived in the OeAW Phonogrammarchiv with assistance from Hanna Vettori (Signature: 20180706.G001).

14 After the birth of his first son, he was called Abu Amjad* - see the additional notes in the running text. 
The interview partner narrated that he had carried some typical qualities he had in his previous life over into his current life: Something that has stuck with me from my past life is that I like celebrations. Anywhere there is a joyous wedding going on, I'll be in the thick of it! His passion for farming was also a quality he had retained.

But other qualities from his previous life had been reversed. He told us that he had loved weapons and munition in his previous life but now detested weaponry of every kind. He shudders every time he hears shots ringing out now and dislikes being present when shots are fired even to celebrate weddings or other special occasions.

The interview partner repeatedly came back to the topic of the material poverty that had been characteristic for his previous life: My previous family - they are good people, I have a good relationship with them right up to the present day. [But] they are poor and Abu Amjad*, who I was in my last life, died poor, he lived

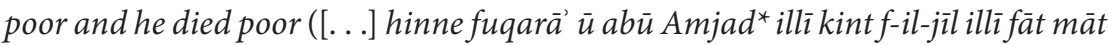
faqìr, 'àyish faqīr $\bar{u}$ màt faqīr). The interview partner explained how strongly poverty had affected him in his previous life and commented that he still feared it today: ana bakhäf min al-fuqr l-il-yawm! It meant a great deal to him, he told us, that he had enough money at his disposal in his present life. He was always careful with money and economical because he knew what it was like not to have money from his previous life.

The interview partner emphasised what was exceptional about his case several times - that he was a nätiq with extremely precise, accurate and detailed memories of his previous life, including all the people who had played a role in this life and their stories: Abu Amjad bya'rif kull shī-Abu Amjad* knows everything - people in his village say, referring to the fact that he knows all the "old stories" due to his detailed memories of his previous life. The interview partner remarked that his knowledge of previous events was not stored in "normal" episodic memories, but that it came to him in flashbacks: when a person (somebody he already knew in his previous life) spoke to him, specific (former) relationships, circumstances and sometimes also secrets would suddenly rush into his mind.

Interestingly, the interview partner is called "Abu Amjad", his previous name, by the people he already interacted with in his previous life. Local people accept that he lives in the village "in two generations" [ $f \bar{j}$ jillayn] and deal with this "normally" ['ādi ] - just as it has become normal for him: I know what I was in my last life and what I am in the present, I have two pictures!

The interview partner described the generation-long conflicts between the two clans he belongs to in considerable detail. "Family A" (or "kinship group A", to which he previously belonged) had been very influential during the Ottoman 
period and the period of the British Mandate. All the families in the village had taken the side (or at least sought to keep on the right side) of this family apart from "Family B" - the family the interview partner belongs to now in his present life. His grandfather in his present life in Family B had opposed the dominance of Family A - and that was why he had hated Family B in his previous life and sought to foil their plans. The interview partner explained that Family A collaborated with Ottoman rule and collected taxes for the Ottomans. The family maintained order and exploited other families. Those who disobeyed Family A were conscripted into the Ottoman army. This was what had happened to the interview partner's grandfather (from Family B), who had been compelled to serve in the Ottoman army for eleven years of his life. But he rose through the ranks and gained the status of an officer, and his last war had led him to Sanaa in Yemen. His superior officer told him he could go home if he "liberated" Sanaa. He finally liberated Sanaa and was permitted to return to Palestine. As the interview continued, the interview partner described the background to his grandfather's conscription: Family A had made Family B an offer. If the great-grandfather (in Family B) had been willing to give Family A a parcel of land, his son would have been spared from joining the Ottoman army. As the great-grandfather was about to put his fingerprint on the document, his son intervened and said he would rather join the army than cede the land to the "corrupt" family (Family A).

The interview partner described how Family B had been harried in previous times and how the family land had been confiscated parcel by parcel. However - by an irony of fate, as it were - the situation had been reversed with the founding of the state of Israel: Now it was Family A that was dispossessed of their land. Due to their past wrongdoing, the interview partner told us, they lost all their land, which had "made up half of Galilee", to the Jews. As time went on, Family A became increasingly impoverished - while Family B managed to accumulate the means to live in relative comfort.

The rivalry between both families remained intact throughout most of this. The interview partner described that he still had memories from his previous life of many deaths and severe injuries resulting from this feud. But he maintained silence on the issue today to avoid reopening old wounds. His nutq case had had an enormously positive effect on the relationship between both families.

Finally, the interview partner also talked about his wife from his previous life. Political upheaval and the drawing of nation-state boundaries were also addressed latently in this episode. In his previous life, the interview partner told us, he had taken his wife from Zarqa, a city and province about $200 \mathrm{~km}$ east of Abū Snān in what is now Jordan. Contacts between the Druze in Upper Galilee and those in the province of Zarqa are not particularly strong, and he no longer 
knows how they got to know each other. They had a very good marriage, at any rate, as he narrated to us: His wife had been a "good woman", although she lived (as he did) under exceptionally difficult conditions: hiyya kānat mnīha; hiyya $k \bar{a} n$ 'äshat fì fuqr ū zilm ù sijn" - she was good. She lived in poverty, oppressed and in captivity. As the interview partner remarked, his wife in his previous life had "survived" him. When he then began to "speak" as a three-year-old, she was one of the people he always kept in close touch with. He used to visit her once or twice a week, and his mother in his present life also visited his previouslife mother right up until her death. He had never forgotten his wife from his previous life, and when she died, he carried her coffin at her burial. It was usual, the interview partner mentioned, for coffins to be carried by the closest family members of the deceased. He felt an inner need to carry the coffin.

When I asked whether he continued to keep in touch with his previous wife's family and her descendants after her death, the interview partner answered: Yes! When the state of war between Israel and Jordan ended in the nineties and a peace treaty was concluded, my previous wife's relatives came to visit. My father (in this life) was very open and invited them to a big meal. He laid on a big breakfast for the entire village!

\section{CASE F: | "It turned out to be a lovely photograph, but it feels strange" - A nätiq affected by the transience of time and clashing expectations}

The following interview was recorded in a traditional-looking Druze village perched on the mountainous ridge between Abū Snān and Ma'alūt. It took place in the private dwelling house of a local historian who had himself written a book about nutq cases among the Druze in northern Israel. It had been important to him to write the book in Hebrew, he told us, so that "everybody", including the Jews, was well informed in relation to this phenomenon.

A young English teacher, Salim, was among those invited to join us. $\mathrm{He}$ recounted his - not entirely frictionless - life between two generations in detail. His return as a nătiq exemplifies "structural" problems that arise in connection with nutq cases and are linked to transformations wrought by time: A näțiq can only continue from where the deceased person left off in a very limited sense. ${ }^{15}$

15 The interview was conducted in July 2018, partially in English and partially in Arabic. In addition to the nătiq, the local historian Raja F., Joe N. and Gebhard Fartacek were present. The audio recording has been archived in the OeAW Phonogrammarchiv with assistance from Hanna Vettori (Signature: 20180703.G001). 
It started when I was five years old. We were at the wedding in 'Isufiyā. My parents were occupied with other families and I was playing with the kids. I kind of remember that I had a fight with some of the kids. I was the chubby kid of the crew. I was always being picked on. I remember I got a hit on the head at a certain point. Someone hit me on the head with something, and then I just walked, like uncontrolledly. I went out of the wedding. I crossed the street, I walked for five to ten minutes and I just came to a door. I knocked on a door at a house, and this old woman opened the door, and I said: "Hello, I am your son. You are my mother". And I went in, there were five people in the room, and I said: "You are my brother, you are my sister, your name is, your name is" and then I blacked out.

The interview partner described this moment as a flashback during which he was in an extraordinary mental state: It wasn't me that was talking. I was being controlled. Like I was on strings and someone was controlling my every movement.

The interview partner can no longer recall what happened immediately afterwards. He was in a car when he woke up. He can remember that his parents picked him up. After this incident, he became ill. He had a headache and a high temperature and was generally unwell. His family from his previous life heard that he was sick and came to visit him. On their first visit, his mother, sister and wife from his previous life came. They brought photographs.

His illness became so severe that he could not even stand, but its cause remained unclear. His family from his present life and his family from his previous life joined forces to take him to hospital.

He recovered his strength slowly and visited his past-life family, and they also paid visits to him and his present family. But as time went on, things became progressively more complicated. His family from his previous life started to visit him ever more frequently.

These visits became too much for his parents in his present life: I started getting too much attention [from my past-life family], and at a certain point even my mother asked me not to say anything when they come, like, "Don't say anything, be quiet". But the interview partner felt a strong desire to talk to his previous family. The person that I talked to the most was my sister. Her name was Muna*. We were really close, and every time she came, I used to hug her and even sit on her lap. I felt really safe when I was with her. She didn't ask for information.

As the interview partner articulated, his sister, mother and wife from his past life were neither sceptical nor intent on securing any advantage for themselves. His previous brother Fadi* was, however, extremely sceptical and unaccepting of him: Fadi* started to probe what I said insistently; he didn't believe me! 
The interview partner described establishing an exceptionally close relationship with his family from his previous life and being present at special family occasions, like weddings. Following such events, he began to remember more and more. He could remember the first birthday of his eldest daughter (from his previous life), for example: He could see the exact colours of cakes, T-shirts and gifts before his mind's eye. His family from his previous life then showed him photographs. They matched his description perfectly.

After supplying this proof, his relationship with his mother (from his previous life) became even deeper and he began to stay overnight at her house regularly. His personal problems, however, became increasingly severe, as he told us. He was trying to find his balance between two lives. This was exceedingly difficult for him and his parents. It was emotionally stressful, too. He remembers calling his "other mother" Mom, for instance, and his present-life mother being unhappy about that.

He recalled an occasion where he was asked to prove something to his family from his previous life by sharing a memory. There were five people in the room, including his nephew, his sister and two of his brothers. His brother Fadi* demanded a form of proof from him. The interview partner began telling a story about driving to Tel Aviv with his sister and stopping at a pancake house. They ate there, but then they had no money to pay the bill. They were stuck and he had to search his car for change. When he told this story, his sister began to cry and said: Nobody knew that! The interview partner was at a loss to explain what had prompted him to reveal this secret.

The interview partner said that he had been asked fewer questions after describing this particular incident from his previous life. But his past-life brother Fadi ${ }^{\star}$ remained suspicious. Fadi's ${ }^{\star}$ rejection of him came to a head in an incident in the year 2005 when his brother murmured: It's not him, he is a liar! On hearing this, the interview partner's present-life father told his past-life family that they were under no obligation to visit their son and pointed out that it was they who had actively sought him out. After this incident, his family from his present life no longer wanted him to meet up with his previous-life family. For ten years, he did not see his siblings and his mother from his previous life.

Recalling the cause of his death had been quite a gradual process for the interview partner. To summarise somewhat: He had been driving through the Gaza strip on a patrol during his military service with the Israeli army, he told us, when he fell victim to a Palestinian assault together with two other Israeli Druze soldiers. In his present life, he had developed a close friendship with the son of one of the other fallen soldiers (initially without being aware of the connection).

The interview partner finally described his relationship to his two daughters from his previous life. One of them is a year older than he is in his present 
life, and one is a year younger. He met his elder daughter (in his present life) as a fellow student when they both took the same course at the University of Haifa. He had only recently become close to his younger daughter. He had been invited to her wedding a short while before, along with his present-life fiancée, and asked to stand in a line with the other relatives, the families of the bride and groom, to accept good wishes at the wedding. The situation was strange for his fiancée: She had come to the wedding together with him and suddenly found herself alone while he chatted to other guests and they snapped pictures together. Things became even stranger when the photographer took a photograph of him with his two daughters and his wife from his previous life. Pictures were also taken of all the relatives of the bridal couple with their respective partners: I stood there next to my wife from my previous life as if we were a couple. It was a beautiful photo, but it was awkward. [...] My wife from my previous life is 25 years older than me.

As the interview partner told us - smiling, yet with a furrowed brow - his present-life fiancée is not happy with the situation. The question of whether his wife from his previous life should be invited to his own wedding (set to take place two weeks after the interview) had not yet been resolved.

In relation to the scepticism of the interview partner's (previous) brother, it is interesting to note that I later discovered from other sources that this brother was embroiled in a legal dispute with the previous wife of the nattiq. According to my source, the brother had taken a court case against the widow of the nattiq because he felt that he had looked after his sister-in-law after his brother's death and was now entitled to the widow's pension (or at least a share of it) that she received from the state of Israel on account of her husband having fallen as a serving soldier in the Gaza strip. This was the context - an outsider's view suggested - in which the appearance of the deceased on the scene in the form of a nătiq had proved to be most unwelcome to his brother.

\section{CASE G: | "At the beginning, the boy always said that his mother in this life was not his mother, but that subsided over time" - A Syrian doctor speaks about his nephew}

Taqammuṣ is [...], when a human [insān] dies, then his soul [rüh] does not disappear; it wanders to another person [shakhs]. A child is born and the soul lives another life - and life continues in this way. The soul migrates from one person to the next for many generations. That is the religious understanding in the Druze faith. 
A doctor from Suwaydā' (aged about 50) who had fled from the war in Syria to Austria spoke in a differentiated way about the principle of reincarnation and cases of "speaking" children linked to it. Yes, the Druze believed in it, but he personally struggled a bit with the concept. He asked himself where the extra people in the world come from if everybody is reincarnated, for instance. But he had experienced a nuṭ case in his own family. ${ }^{16}$

My nephew (my sister's son) was born. When he was small, he was very afraid of water. That meant that whenever he was in the bathroom, to be showered, he would panic and run out of the house. After a while - when he was able to talk, at around the age of two - he began to name some names and details. He told us: "I come from such and such a place; and I had to die, because -"

By coincidence, we knew the place and the person who died there. It was a child who drowned in water. And that was the reason why the child was afraid of water.

He said, "My name is Nawris*! I am from the neighbourhood of -"

[...] He was reborn in another village. But whenever he visits his previous village, he goes straight to his family from his previous life!

As the interview went on, the interview partner clarified more and more details of this case. He reported that his nephew knew the names of certain people as a small child, including the names of his previous mother and of certain siblings. As the present family of his nephew are distant relatives of his previous family and both families were personally acquainted, they did not have to search for the previous family for long: Even though both villages are some $90 \mathrm{~km}$ apart, it was immediately obvious who the boy was referring to.

They drove to the village and the boy recognised the members of his previous family immediately. He was also able to prove his story by remembering an entire series of specific details about his past life. He had possessed a birdcatching trap, for example, that he had hidden in a special place. When he then returned to his former village as a reborn child, he showed this hiding place to the family.

16 The interview (Arabic, Syrian dialect) was conducted in July 2019 in the Phonogrammarchiv of the Austrian Academy of Sciences. Gebhard Fartacek, Hanna Vettori and Wansa Nasrallah were present. Wansa Nasrallah, herself also a refugee from Syria, is a personal acquaintance of the interview partner. Nasrallah, a trained psychotherapist, undertook a three-month internship at the OeAW Phonogrammarchiv from 1 July to 30 September 2019 as part of the FWF project P28736 (with funding from the refugees' internships programme at the Austrian Academy of Sciences). The interview has been archived at the Phonogrammarchiv (Signature: 20190718.G001). 
The interview partner explained that the boy who had drowned in the fatal accident had been 12 or 13 years old. Two children had gone to a pool to swim there. One of them fell into the water and got his foot caught under a stone. The pool was not a public swimming pool, but a pond near the village. The other child called for help and ran into the village to tell people what has happened. People came to the site of the accident and searched for the boy for about an hour. But they only found his body at the bottom of the pool.

The interview partner reported that his nephew, now a 45-year-old man, had not been severely affected by his previous life. His fear of water had receded over time, and he had learned to swim later. Today, he is very strong and vigorous. He still loves his family from his previous generation, as he always did, and has always kept in close touch with this family. There had, the interview partner told us, never been any trouble between the two families. Ultimately, the case had strengthened the bond between them.

The interview partner remarked that not all nuṭq cases were so frictionfree. He told us that lots of families do not allow their children to speak about their past lives out of concern that the children could develop psychological or social problems. It can occur, he commented, that a family is well aware of the circumstances of a child's life in the previous generation, but that no dialogue or only very limited exchanges take place with the child's previous family. This is especially likely when a death was in some way problematic and the nattiq or nattiqa could possibly reveal its exact circumstances. He cited the following case as an example and noted that it had occurred 20 years ago:

A student from Majdal ash-Shams [a Syrian Druze town on the Golan Heights annexed by Israel in contravention of international law] was studying in Syria. When he went on an excursion to Suwaydä once, he suddenly recognised the place where he had formerly lived. He remembered that he had lived there and been murdered. The site was examined and the upshot was that the crime - that nobody had ever been brought to justice for - was cleared up.

\section{CASE H: | "These feelings are very difficult... one wants to live between two generations, the previous generation and the current generation!” - A nätiqa from Syria shares her biography as a voice message}

My name is Samira*. I am 22 years of age. I am going to talk about my previous life. My name in my previous life was Lina A. ${ }^{*}$ was married to Imad $R .^{*}[\ldots]$. He was [. . .] a singer. I died in my previous life as I was giving birth to my son. 
When I was a small child, I began to remember my past life. I cried a lot in front of my family. [. . . My previous husband] dedicated a song to me after I died. The song is called [...]. Whenever I heard it, I began to cry and cry. I only stopped crying when the cassette recorder was turned off.

Later, when I was already able to talk, my mother brought me over to the wardrobe. She wanted to change my clothes. I began to cry, and I didn't want to wear the clothes she had ready for me. I wanted to get dressed in my new clothes (from my past life). After I got married, I got pregnant immediately and I gave birth to my child. You must understand: My clothes (in my past life) were new. That was why I did not want to wear these other clothes.

When I started to talk, my family gave me a teddy bear. I was about four years old. They said to me, "This is a teddy bear", and I said to them, "This is my son!" They asked, "What is his name?" and I answered, "Samir*!" I called him after my son (in my past life).

[...] In my life before this one, I had a brother. When he heard the story that I was a nätiqa, he came to my family at home and wanted to see me. My family said, "Come and look at your brother!" I immediately identified him as my brother and embraced him. And we asked each other how we were. He said, "I would like to take you to our house, to see our mother!" And I said, "Yes, I'll come with you!"

And I went with him, and when we got to the neighbourhood where our house is, he asked me if I knew where our house is. And I did know the way straight away - I led him to our house! And when I stepped into the house, I greeted everybody. I knew everybody who was there and they showed me a photograph album - and I recognised the entire family.

In my previous life, I possessed a lot of gold, and my mother took the gold off me when my son was born and I was in hospital, wrapped it in a tissue and hid it.

And when I saw my mother again, I asked her about the gold, "Where is the gold that you hid? You must have hidden it in the false floor (shifa)!" Because I knew that was her usual hiding place for cash and jewellery. When I mentioned the gold, my mother refused to talk about, it and she said, "Take her away and don't bring her here again and forget about the topic!" to my brother, and "We want to forget the story in every respect, as otherwise there will be problems". My mother had said nothing to my husband, and she thought that a lot of problems would crop up if I raised the issue.

[...] I asked my mother a few times where the gold was. She reacted in a very annoyed way. She told my brother that they, as a family, should forget the stories and that I shouldn't mention the issue again. She didn't want to see me at 
home with the family again. I left and I was sure that she had taken the gold. But I wasn't interested in the gold. I wanted to see my son and find out how he lives and see what I lost.

When I was older, in the ninth class or so at school, there was a neighbour who knew Samir's 'family. She spoke to the family and told them that I was Samir's ${ }^{*}$ mother and would like to see my son (from my previous life). And she let them know that I was thinking about him the whole time and that I was sad and simply wanted to see him and nothing else. I don't want anything from him and I don't want to exploit him.

She told me that I should go around to their house to talk to Samir*. We will see each other often and talk to each other, God willing.

We went to their home and asked if Samir* was coming to visit us. He came with his uncle. We spoke about my story, and he told me the story and everything he knew. He knew that I am his mother. I hugged and kissed him.

I also visited him at home in his own house and got to know his siblings - the siblings from the second mother, of course. After I died (in my previous life), my husband was alone for four years, and then he married a second time and had two daughters and a son.

The most important part is that we stayed in contact after I got to know my son. He is engaged now and works in Saudi-Arabia. He is doing fine. We talk to each other every now and again. But it is a great strain for me. Yes, we talk as a mother and a son. But his fiancée is jealous and feels attacked. And my husband is jealous, too.

It's difficult for me, because he is my son: I need only see a photograph or hear his voice and my heart becomes heavy! It feels as if my heart is breaking. If I don't hear anything from him for a while, I get worried. And I'm afraid that something could happen to him.

These emotions are very hard to bear; this soul that remembers its previous life-circuit and speaks. And especially when one has a child. One remembers the past generation and one remembers the past life and wants to live between two generations, the previous generation and the current generation.

And in my past life, he and I married for love.

And that is very sensitive. I have a strong bond [...]. Of course, jealousy and other forms of sensitivity result.

That is my story. I hope it is of some use to you! 
This voice message was sent in the summer of 2019 from the Syrian governorate of Suwaydā' via WhatsApp. ${ }^{17}$ In a text messenger chat that followed this message, Samira ${ }^{*}$ explained the ambivalence and the negative influence of her previous life on her present life: You know, I really suffered from all the thoughts [about my previous life] and mainly because - I wanted to go to my son and initially I couldn't! Later on, a very close relationship with her son from her past life had developed, but at the same time, tensions and jealousy had also arisen: her fiancé (in her present life) viewed this close relationship with suspicion, and her son's fiancée became progressively more jealous, too. Their meetings had thus become rarer, and they had begun to speak on the phone much more often.

The interview partner also reported that fears of dying from the same cause as in her previous life had plagued her: During her pregnancy, she had felt intense fear of labour and been concerned that she or her child might die during childbirth.

She ended her reflection by highlighting the economic inequality of both her families as an issue she struggled with: nutq is a problem for me because of that. I had a life with lots of money (in my previous life) and I could do what I wanted. But in this life, my circumstances are very difficult. And I began to compare both lives ... and that is hard to put up with!

\section{CASE I: | "Nice and not nice" - A näțiqa from the Shūf mountains in Lebanon reports on a difficult childhood}

"Hilw wa-mū hilw ..." - nice and not nice was what it had been like to be born as a nâtiqa, a "speaking" girl - this was how a 40-year-old woman from the Lebanese Shüf mountains narrated her own life story to us, quite serenely. ${ }^{18}$

The interview partner explained that she had still been very closely attached to her previous life when she was a small child. She had longed for her "old"

17 The immediate recipient of this voice message was Wansa Nasrallah (see the footnote on Case G), who knows the interview partner personally from when she was still in Syria. This voice message was translated and archived at the Phonogrammarchiv with assistance from Hanna Vettori (Signature 20190824.G001).

18 The interview took place in Arabic (Lebanese dialect) in the interview partner's dwelling house. Apart from the interview partner, the following people were present: Gebhard Fartacek, Lorenz Nigst, a friend of the interview partner's who had led us to her, and - for some of the time and/or in the background - the interview partner's husband and son and a housekeeper. The interview has been archived at the Phonogrammarchiv with assistance from Amjad Khaboura (Signature: 20161017. G001). For more on the specific context of the interview, see Fartacek (2017). 
family and rejected the family of her parents in her current generation. When she was four years old, chance (bi-ș-șudfa) had brought her past her previous house and she had recognised her "past" mother (ummī yilli kānat). Looking through the front door, she caught sight of a photograph of herself, a photograph showing her as a child in her previous life. She began to cry and scream, "Hay Māmā!" - that is my mother! and "Anā bidd̄ Māmā!" - I want my mother!

The interview partner knew that she had previously been called Amal ${ }^{*}$ and had been tragically ripped from life by cancer at the age of 20 . She could remember the names of all her (past-life) siblings, and she knew highly specific family stories that made it clear that she was indeed the Amal ${ }^{*}$ who had died (and not a liar). She knew, for example, that her sister Lama* had broken her leg on her account when she went outside in winter to fetch snow (which little Amal $^{*}$, who was sick at the time, loved to eat). Lama ${ }^{*}$ had to wear a metal brace for a long time after that.

The definitive proof (dalil), however, as the interview partner narrated the story, was that she remembered an especially thorny and "secret" family matter that nobody knew about except her: Her father had worked in Saudia Arabia and had an extra-marital affair with a woman there. She found the handwritten letters exchanged between her father and his lover. She did not want her mother to discover what was going on and hid them under her mattress. When she died, her bed was left untouched. And when she then returned as a small girl in her present life, she said to her (previous) family, there are things from my father. I hid them! And then she went to her previous bed and lifted the mattress, and her father's love letters came to light!

After that, all the problems started, the interview partner told us. Her father had gone berserk, accused her of lying and beat her - despite the facts of the matter being obvious and unambiguous. Her previous-life parents' marriage subsequently broke down, and the interview partner was held to have destroyed the house ([anā] harabt al-bayt) by revealing this family secret.

She reported that she had brought many of the characteristics she had had in her old life into her new life along with her - she had not been a meat-eater and still did not eat meat, for instance, and she had had a birthmark on her face then and had one now. She showed us a photograph from her previous life of Amal ${ }^{*}$ as a little girl with a prominent birthmark on her face, and she has a clearly visible birthmark now, too - albeit on the other side of her face.

The interview partner pointed out several times that "speaking" children must be able to prove their stories unambiguously. She commented that this was tiring for the children (byit ab al-walad kithir): they were often rejected (even after supplying proof), they felt torn between both families and they faced 
considerable pressure. These children could become nervous, restless or troublesome "problem children" (mushkiljī).

In her own case, however, the interview partner narrated that she had come to terms with her story. Looking across to her husband and her son, she remarked that she was happily married now and had found closure on the turmoil of her childhood. Her mother (in her previous life) had become an old woman by now, and visiting her was somehow tiring: Every time I visit her, she gets very emotional and starts to cry when I get there. That brings everything back up again for me, and I get a headache that lasts for three days afterwards!

During our conversation, the interview partner raised two more issues that sometimes also cropped up in other interviews. One of them was the question of whether a death and a birth had been perfectly simultaneous, and the other was the phenomenon of having memories of more than one previous life. In relation to the former issue, the interview partner reported that her birth (in her present life) had taken place three months after Amal's* death - in apparent contrast to the belief that a soul leaves a person with their last breath and slips into the body of a newborn baby taking their first breath.

This "time in between" was referred to as intiqāl (literally: migration) by the interview partner, a term used in this context in Lebanon, Syria and North Israel alike. The logical explanation for the gap is that there was a short life in between, and it is common enough for infants to die after only a few days, weeks or - as in this case - three months (and plausible that they would not accumulate specific memories in such a short time on Earth). While this "time in between" does not constitute an insurmountable obstacle, the interview partner commented that the discrepancy between the time of death and time of birth had played into the hands of people who did not believe her and accused her of lying when she was a child.

In relation to the second question, the interview partner first described the nutq case of a sister of hers with memories of living in two past generations. She herself, the interview partner narrated, could remember having lived as Salam* in Suwaydā' (in Syria) before her life as Amal* and her present life. This was when the Druze had been engaged in a struggle against the Ottomans and subsequently against the French. She remembered being close to 50 years old and being at home alone with her three sons when the Turks were hammering at the door of the house and demanding Abu Ibrahim*. She had pressed her back against the thick wooden door, she said, while the Turks maltreated the door from without with their swords. They had finally penetrated it and bored 
through her body, she recalled, and the last thing she had seen was her son clutching a curtain and hiding behind it. In her previous life as Amal ${ }^{*}$ (in the Shüf mountains in Lebanon), she was able to remember this earlier life (in Suwaydā', Syria) better than she remembers it today, in her present life. She found the way back to her family in Suwaydā’ as Amal* and heard much of what she knows about her life in Suwaydā', the life preceding her more recent previous life, from her mother (from the past generation). She told us that she had undertaken a journey to Syria in her present life with her previous-life mother and that her mother had shown her the house in Suwaydā. She had thus had an opportunity to get to know relatives from an earlier life preceding her previous and present lives.

\section{CASE J: | "I remember my previous life to learn from it but not to step into it (again)" - A nätiq who is aware of his previous family but reluctant to initiate contact}

The following interview was conducted with a nätiq who had shared his story publicly in contexts including a Lebanese TV show. ${ }^{19}$ The interview partner described having been a criminal who smuggled arms and was involved in dubious deals in his previous life. While he did not expressly bring up the topic of the Lebanese civil war, the circumstances described clearly point towards various facets of the armed conflicts of those years. The interview partner's memories seemed to weigh very heavily on him as we talked: He would like to gain closure on his previous life, but letting go is not easy and the process is ambivalent. $^{20}$

The interview partner started his story by recounting that he had been active as a pawnbroker and a smuggler in his previous life. He had worked in the neighbourhood of Buq'ātā and Samqāniyya, around 'Ālayh and here on the mountain around Dayr al-Qamar. He had possessed a very expensive car, a

19 TV-Show with Tony Khalife: "älam al-mutaqammișin", broadcast on 10 November 2014: https://www.youtube.com/watch?v=DzZbQp22R9A (min 04:1020:02). See the contribution by Lorenz Nigst in this reader.

20 The interview was conducted in Autumn 2016 in a private dwelling in Dayr al-Qamar in Lebanon in Arabic (Lebanese dialect). Apart from the interview partner, Gebhard Fartacek, Lorenz Nigst and two Lebanese acquaintances of the interview partner were present, a young Druze man and a Christian woman who were fascinated by the topic of reincarnation. The interview was archived in the Phonogrammarchiv with the help of Hanna Vettori (Signature: 20161026.G001). 
BMW 745 - and the car was responsible, he said, for him having found the trail leading to his previous life. The car had, as it were, led him to the house (of his previous life) in the village of [. . . . In this way, the interview partner told us, he had found his things (weapons etc.) from his previous life, but he would come back to that later.

The interview partner began by narrating an incident he had been involved in detail. He was smuggling "hot loot" for a Christian family from the village of [...] to another locality, and he was going to make 1,500 USD on the deal. He arrived at Checkpoint Mukhtār, and the police signalled for him to stop at a roadside check. He did not stop. They pursued him to [...] and opened fire there. When they shot at him, he originally believed that he was coming under fire from the Lebanese army. But his TV appearance a few years beforehand had led to this picture changing: After I was in Tony Khalife's show on television, the interview partner reported, a man from Mazra'at ash-Shüf contacted me and told me that my story was like a story that he knew. According to this version, it was not the Lebanese army that had shot me but the Lijān Sha'biya [presumably a unit of the "People's Liberation Army"] and the man who had shot me wanted to get to know me and to talk to me. And I went to this man and got to know him!

The interview partner went on to relate that the shot fired at him had been fatal, that he had been married to a woman called Rema* and that he had left two children behind, Hawla* and Dunya*. Interestingly, he was unable to remember his own name in his previous life.

The interview partner then told us about his brother, Amir*, who had been in the same line of business and worked together with him regularly. On this occasion, too, his brother had been with him: I can remember my last picture of him, and when I talk about it now, I have this picture right before my eyes: After I was hit, I drove over to the edge of the road and my brother began to shoot back like a madman. I can see it very clearly in my head: I was looking at everything from above [from a bird's-eye perspective]. I remember these pictures from the perspective from above and the perspective from within the car. ${ }^{21}$

21 As the nattiq told us towards the end of the interview, the fatal incident was stored in his memory as a video (and not as a series of individual pictures), and he can still visualise the sequence of events unfolding: I see myself being shot at, slumping away from the steering wheel, my brother shooting back [...]. Other interview partners describing their deaths and/or the moment of discovering their previous families also said that these were not "normal memories" but like flashbacks "in a film". 
As the interview partner told us, the bullet that hit him had left a scar. And when he was born again (in this life), he had an (inexplicable) scar on his abdomen right from birth. The doctor assisting at the birth noted it down in his records. It was on account of his scar, the interview partner recollected, that Tony Khalife had decided to invite him onto his show as an interview guest.

One day - in his present life - the interview partner was working as the organiser of a wedding procession $(z a f f a)$. He was accompanying the procession on foot when the crowd passed through a particular junction. It was the junction where he used to turn off for his house in his former life. And he was suddenly able to recall many things. All sorts of events from his previous life suddenly started racing through his mind. Together with another person, he left the wedding procession. They went to his former house. He saw his brother's car and said, that's not the car I died in. They went into the house. He found the car that was his in his past life. And he found his box (he could still remember the hiding place). When he opened it, his arms and his money were still inside. ${ }^{22}$ Nobody had touched the box in the time that had passed. The interview partner went on to tell us that he had left his previous house again immediately. He left everything just as it had been and told nobody about what he had discovered. He does not want to see his family from his past life again and refuses to initiate contact with them.

The interview partner went on to describe several ways his present life differed from the previous life he wanted nothing more to do with: he had been a bit heavier in his previous life, worn a beard and always been armed - a typical miltiaman. Art, culture and society had not interested him. In his present life, however, he finds all kinds of weapons deeply repugnant. He is an artist, a theatre person and incredibly open to different cultural traditions. He is now trying to do exactly the opposite of what he did in his previous life.

When I asked whether he never felt the desire to talk to his children (from his previous life) he replied: Of course, I want to see my "natural children" (atfāl tabi'i $)$. I miss them, but I don't want to meet them. I remember my past life to learn from it, but not to step into it (again). It's over! I died in my old life and became somebody new. And I want to continue this new life now. I want to leave my old life behind!

Remarkably, one of the examples the interview partner drew on to explain his attitude was a nutq case in his circle of friends that had unfolded as follows: One

22 Later in the interview, the nattiq described this money as "poisonous" because it came from dirty business. On the emic classification of "clean" (honourable) and "dirty" (dishonourable) money, see Kastrinou et al. (2020). 
of my friends, his father died. They were fighting together on the front line. The father was killed in an assault. And the son escaped. The father was born againas the son of his son. And they still talk about the incident today. The son says, "I don't trust you because you fled back then and left me alone (on the front) by myself!" to his father in his present life. [...] And when the small child began to speak about his previous life, he only needed to look his father in the eye to remember and say, "You are the one who killed me!" That was not right, of course, because the father only (cowardly) ran away (abandoning his son). But the fact of looking into the eyes of someone from one's past life triggers a lot! ${ }^{23}$

As the interview partner expressed with reference to this case, "a lot would be sure to happen" if he were to see his old family again. Seeing them again would be stressful: It isn't pleasant when somebody thinks about their old life (and talks about it a lot) as they then have two personalities. In his previous life, he was a father and had children and a lot of responsibility; and now he also has (different) responsibilities. I don't want to see my picture from the past. I see two families. The old family has its natural idiosyncrasies and the new family has its own idiosyncrasies. Carrying (these different) responsibilities is unbearable: a young child feels the weight of responsibility (from their previous life) but also feels that they cannot fulfil the demands flowing from this responsibility.

The interview partner told us that he had once driven to his "old" house in his car at a time when his former family were not at home. And I stopped the car. I went across the street, and a neighbour saw me as I was crossing and asked me if she could help me. And because I knew that they might all recognise me from [the television show with] Tony Khalife, I turned around quickly, went back to the car and "fled".

As the interview partner told us, Tony Khalife had spoken to every member of the family before the programme. We spoke on the phone and he asked me where the "old" house was. I answered: "I don't want to say that!" but they went to the mayor and searched the residents register for the name - and then they knew where the house is. I didn't tell them!

The Lebanese Christian who was present asked the nattiq, Do you believe that your old family saw it [the television show with Tony Khalife], too? Do they know about you now?

23 This case was also narrated to us in October 2016 by another interview partner in a somewhat more detailed version (Dayr al-Qamar, OeAW Phonogrammarchiv Signature 20161024.G002). 
The nattiq replied, Of course, they know about me. They saw my face and they know who I am. In the programme, I said that I had driven into the village with the car and then made off again [...]. But they also know that I don't want to see them - that's how I put it in the programme. If THEY want to meet me, I wouldn't have a problem with that. But from my point of view, a meeting isn't necessary!

\section{A tentative ethnographic analysis of the narrated nutq cases}

Certain patterns are discernible in the nutq cases introduced in the interview excerpts presented here, both in relation to the sequence of described events and to the different outcomes of cases in terms of whether a close relationship is established between "speakers" and their previous families. Together with an entire series of further interviews conducted with "speakers", their relatives and "external" observers and archived at the OeAW Phonogrammarchiv, the interviews presented here supplied the starting point for the ethnographic analysis below.

Before getting further into specific details, it must be stressed that an 'amaliyat an-nutq is not a normal process even from an emic perspective: While the Druze religious doctrine holds that all humans are reincarnated as humans, our interview partners regarded the ability of "speakers" to remember previous lives as a rare and exceptional phenomenon. As the interviews demonstrate, nuṭ cases within the Druze community involve both men and women and can arise in all social and educational strata and in both rural and urban contexts. They appear to occur somewhat more frequently in particular families and regions, however, and the degree to which they have the effect of constituting a kind of kinship relationship appears to vary from place to place.

The analysis below initially focuses on typical building blocks of narrated $n u t q$ cases that were addressed in virtually every interview and thus represent core components that appear to be significant to our interview partners. In a subsequent step, the question of how Druze society approaches the phenomenon of "speaking" children is also explored and the significance ascribed to this phenomenon is probed. The interview excerpts gathered here suggest that this question defies simple explanations: The statements in the interviews reflect a wide range of positions including idealised depictions of kin relationships constituted by specific nutq cases, descriptions of rejections and the hurt that ensued in their aftermath and the oft-voiced view that "speaking" children should be persuaded to forget their previous lives and "fall silent". 


\section{Comparing nutq narratives: Similarities in their structure and content}

When the cases of "speaking" children who found their previous families gathered in our research project are examined more closely as narratives, certain components of their content appear to be typical and are invariably mentioned even in highly condensed and abbreviated descriptions of cases. These typical elements are:

- the cause of the "speaker's" death in their previous life;

- the nature and content of their previous-life memories;

- the moment they discovered or found their previous families;

- the proof that the "speaker" is indeed the deceased person; and

- the reactions in the "speaker's" social environment and the societal embedding of the case in the here and now.

The interview partners generally supplied a moral evaluation of specific cases and the parties involved that went beyond simple description and sought to elucidate the meaning of cases for society as a whole and to clarify the status of cases relative to other cases.

These building blocks are mentioned in virtually every nutq case regarded as complete, although they are not always narrated in the same chronological sequence. While the cause of death, the memories of "speakers", the discovery of a previous family, the furnishing of proof and the reactions of those affected are always described as narrative-episodic knowledge (as hard facts, in other words), the moral evaluation of cases and their significance for the Druze community tends to be embedded in the subjective theories of narrators. Descriptions of cases are often wrapped up with general conclusions about human and divine justice and reflections (revealing a narrator's semantic knowledge) on the importance of taqammus for the coherence of the Druze community.

Looking beyond the level of narrative structure, the cases of "speaking" children documented in the episodic interviews also show many parallels in their content. The causes of death mentioned are often similar, the kinds of memories and proof addressed in the narratives resemble each other and the moments of discovering previous families are often recounted in remarkably similar ways. These content schemata ${ }^{24}$ will be explored in greater depth below.

24 See the discussion in Fartacek (2017: 38-42). 


\section{Ugly causes of death}

The cause of the death that brought the previous life of the nattiq to an abrupt end is a central element in every narrated nutq case. The connection between dying in an ugly manner ${ }^{25}$ and the possibility of being reborn as a natiq/a appeared self-evident to our Druze interview partners. Although there were exceptions (as in Case E), almost all "speakers" reported having previously died suddenly and often violently, for instance of gunshot wounds (Cases A, C, and J) or a snakebite (Case B), during military operations (Case F) or in traffic collisions, plane crashes, electrical accidents or (as in Case G) a drowning. ${ }^{26}$

Leaving the question of the factual manner of death aside and turning to the explanatory models of the interview partners, we find that the "ugliness" of these deaths seems to be attributable less to their direct cause (gunshot wounds, traffic collisions and so on) than to people having been ripped from their lives at the "wrong" time in a way that threw human relationships severely out of kilter. The deaths of mothers or fathers of small children leave a gaping void, for instance, because these parents bear great responsibility for their children at the time of their deaths. Important unfulfilled plans were similarly seen as a reason for being unable to let go, as were still having scores to settle, being bearers of secrets or - as the interview partner in Case F put it - still having something (important) left to say.

These interpretations are also reflected in the semantic knowledge displayed by the interview partners on the issue of why some people have the ability to

25 A clear distinction made from an emic perspective between two fundamentally different ways of dying emerges from the interviews: A "natural death" (al-mawt attabi $\left.{ }^{t} i\right)$ is characterised by people having found closure in their lives and being able to pass away peacefully and with a clear conscience, but an "ugly death" (al-mawt albashi') rips people from their lives violently. Surveying theories in cultural and social anthropology yields the insight that such a categorisation of "good" and "bad" deaths is not unique to the Druze but an important distinction made in many cultures (see Robben 2004; Joarder et al. 2014). In the Middle East, specifically, violent deaths are often conceived of as likely to trigger demon activity. Winkler (1936: 9) reports that an 'Afrit is thought to be created from the blood of a person killed violently. See Fartacek (2010: 127-131) for more on connections between unexplained deaths and the activity of demons (jinn) in Greater Syria.

26 Significant parallels exist between the "ugly" causes of death identified in this context and research results on "previous-life memories" reported by cross-cultural research; see, for example, Stevenson and Haraldsson (2003: 286) or Somer et al. (2011: 459-475). For the various conceptions of causes of death and reincarnation among Alawites in Greater Syria, see Prager (2016), cf. Procházka (2002: 242-262). 
remember their previous lives even though most people's memories cease with the demise of their physical bodies: People who knew that their deaths would cause major ruptures in the lives of the people in their social spheres would cling hard to their previous lives, they believed, and be unable to let go at the decisive point.

The interview partner from the Shüf mountains in Case I who told us about abruptly being tragically torn from her previous life against her will by cancer used a metaphor to explain this: She showed us her hand - relaxed, with outstretched fingers, and then again as a tightly clenched fist, and she explained that people who die a natural death can let go, but that those who are reborn as a nattiq/a had held on tightly to their old lives: they cannot simply let go - and that is why they remember!

This idea of "holding on" to their old lives brings us directly to content "speaking" children remember in the earliest phase of their (new) lives: Their deaths in their previous lives, loved ones and special places, objects or other details.

\section{The nature and content of previous-life memories}

Looking at the cases narrated by our interview partners, the following thematic areas that speakers generally remember and can provide information about become apparent: (1) The manner of death and the steps in which the fatal incident unfolded (seen from a bird's-eye perspective), including the people who were present; (2) people and objects the "speaker" was especially attached to (such as certain family members, friends, a beautiful house, a garden, a beloved sports car or a truck); (3) particular skills and characteristics the deceased person was known for in their previous life (being a technically skilled pilot, a powerful fighter or a vegetarian, for instance), with these qualities sometimes being carried over into the "speaker's" present life.

\section{The moment of discovering or recognising people one was close to in a previous life}

While the process of (unsuccessfully) searching for previous families is scarcely mentioned in nutq narratives, the moment of the (successful) discovery of the former family represents a cornerstone of almost every case study. This momentous event is often described as a flashback by "speakers" (see Cases A, E, F). It is invariably described as "immediate and unmistakable": While those around them may be sceptical, the "speakers" themselves do not doubt, not even momentarily, that they have come face to face with a person or place from their previous lives.

This moment of discovery is always described in the context of furnishing proof in $n u t q$ narratives, and it is normally an integral part of the examination 
process: A nātiq/a is held to be able to recognise a particular place (or a person or an object) precisely because they are the deceased person and nobody else! Witnesses who are present are accorded an important role in this context. ${ }^{27}$

Forms of proof: Characteristics, physical features, knowledge of facts or familiarity with secrets

The kinds of proof furnished interact with the memories recounted by "speakers" and/or with their distinctive characteristics:

--> The nätiq/a is able to describe their death throes accurately and in detail: People who were present are identified, and knowledge of seemingly minor details (that only the dying person could have known) can act as supplementary proof that a "speaker" is indeed a particular deceased person. The deaths depicted often also occurred in the context of historically provable crimes, military operations or terror attacks that make the descriptions given by "speakers" appear authentic and allow details to be corroborated (Cases A, B, C, F, J).

--> The nätiq/a can navigate in a specific environment "as if they were at home there": they know or recognise the names of people that were dear to them, they know where to find what and they are aware of the special significance of certain items (often clothing) (Cases A, B, C, E, F, H, I).

--> The nātiq/a has certain abilities (such as foreign language skills, technical or mathematical expertise, relevant professional expertise) or specific characteristics (such as not eating meat, as in Case I) that appear remarkable in a child and are taken to have been carried over from a previous life.

--> Specific birthmarks can identify a nātiq/a as a certain deceased person although such marks sometimes swap sides (see Cases A and I).

--> Specific phobias that are explained with reference to the cause of death of a nàtiq/a (such as the hydrophobia in Case G) play an especially important role in the proving of nutq cases. Similarly, children may have scar-like marks that seem to point directly towards the mortal agony of a dying person and are sometimes already documented at their hospital births (as in Case J).

In addition to these factors, knowledge of special secrets that could only have been known to the deceased person often supplies the most decisive form of

27 On social anthropology theory formation regarding the role of system-immanent evidence in the context of such "discoveries" and the "proving" of nutq cases linked to them, see Bonß (1995: 90-91). On "self-confirming" explanations and other "expectation certainties" in the local cultural context and the wider Middle Eastern context, see Fartacek (2010: 174), Fartacek and Nigst (2016: 58-63, 2019: 76-78). 
proof. In Case I, for instance, the nattiqa was familiar with a special ritual the family used to perform in secret because they were having problems with the jinn, and she uncovered the love letters belonging to her father that she remembered hiding under her mattress in her previous life.

Other cases feature hidden toys (when somebody died as a child; see Cases $\mathrm{B}, \mathrm{G}$ ), arms caches (like the weapons hidden under a gas tank in Case $\mathrm{C}$ or the concealed pistol in Case E). Practically all cases include mention of some specific items of evidence the deceased person concealed without telling anybody while they were still alive. "Speakers" prove that they are specific deceased people by knowing about and salvaging these "relics".

In addition to the secrets thus disclosed, material wealth such as cash, gold or jewellery often plays an especially important role and is salvaged during the process of providing evidence to prove a case. There does not seem to be a uniform consensus on what should happen to such rediscovered money or objects of value, that is who should be considered their rightful owner, in other words how they should be shared. Our interview partners commented that the moral circumstances of specific individual cases had to be evaluated: Was the money "clean" (gained by honest means) or had the deceased been, say, a miser who had illegitimately put money aside for their own purposes? And in relation to the situation in the here and now: Does the "speaker" need this money (or these weapons etc.) now?

\section{Reactions and the social embedding of cases in the here and now}

Supplying evidence to prove one's case is one thing, but having it accepted by every involved party is another matter entirely. When nutq cases are described, the reactions of all the other members of the affected families are normally also mentioned. How, for instance, does the present family react to a "speaking" child that has just found their way back to their previous family? How do the members of the previous family and (previous) friends appraise the reappearance of the deceased - now in the body of a small child? What role do secrets play that have now been revealed - or could now be revealed? Do some people feel offended, unmasked or even proven guilty of crimes?

In the cases described to us, the interview partners seemed to treat the outcome of cases as an especially delicate question. The appearance of a "speaker" can create new human relationships in a marvellous way and strengthen old ties, but "speakers" can also introduce chaos into environments that had seemed perfectly ordered before their arrival on the scene. The "moral of the story" is thus a cornerstone in almost all narrated nutq cases and often represents a departure point for further reflections in which semantic knowledge is shared. 


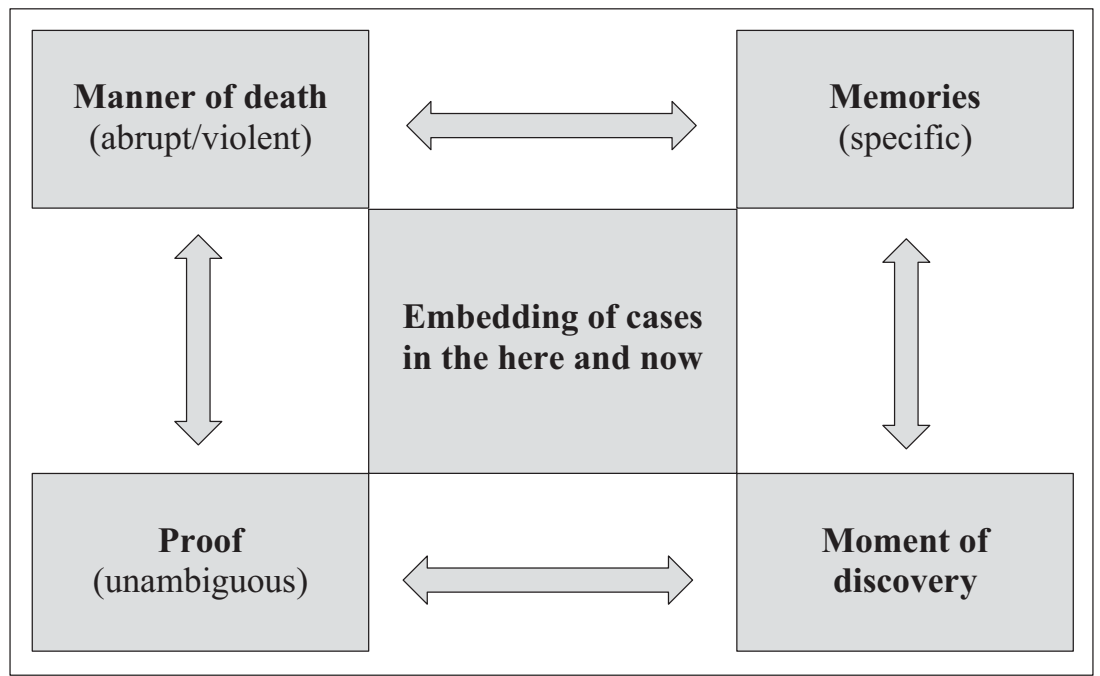

Fig. 8: Plot construction in narrated nuṭ cases. Graphics: Gebhard Fartacek, 2020.

Summarising, it can be noted that the narrated nuṭ cases are subject to strong plot construction (Fig. 8). Core components repeated in narrative after narrative (manner of death, specific memories, the moment of discovering the previous family, the evidence proving the person is the deceased, the significance of the case for the here and now) are ultimately connected in a causal chain of events: A nạtiq remembers his previous life because (1) he was torn from it in an ugly way; on the basis of these (2) memories, he (3) discovers his previous family and (4) proves that he is the person who was parted so abruptly from his life. And all of these elements are, finally, (5) inseparable from the present identity of the "speaker" and/or the general situation of the Druze. ${ }^{28}$

28 It is clear from this overview that nutq cases cannot simply be freely invented. To be credible and to find credence - to fit into the shared religious beliefs of the Druze - cases must have the features and the kinds of proof outlined here. See Siebert (1997: 34) on the constructivist theorisation linked to this. As Siebert points out, the individual knowledge of an interview partner is always relevant for their identity, significant for their biography and - in relation to their recent or present life situation - dependent on its viability. Moreover, the individual knowledge of any interview partner is never random, but always links back to shared collective knowledge. It is important for individuals that they can share "their" knowledge with others. When knowledge cannot be shared and a conflict emerges, the "misfit knowledge" is either corrected or identified as "crazy". 


\section{Establishment of new kinship ties versus rejection: On the ethnosociological realisation of nutq cases}

\section{Preliminary ethnosociological considerations}

From the perspective of the interview partners, the evidence furnished by "speakers" is decisive for determining whether their case is seen as authentic and afforded (social) recognition. Interview partners were confident that the result can be determined with little ambiguity in almost all cases. The following section offers a cautious analysis - based on the material gathered - of consequences that flow (or can potentially flow) from the social recognition of $n u t q$ cases. At the level of kinship, the question of how personal and collective identities are constructed is central. At the wider level of society, the question arises as to what discursive processes nutq cases are embedded in.

When a "speaking" child turns up at the door of a family home and succeeds in proving their identity with a given deceased person successfully, this newly established kinship relationship and the questions it throws up for possible inheritance claims, obligations to provide for others, or social responsibilities do not seem to be subject to firm rules anchored in customary law but to be navigated on a case-by-case basis. To summarise the statements of our interview partners, it appears that the extent to which "previous" families feel responsible for "speaking" children is mainly an emotional matter ("âtifa) rather than an issue for customary law ('urf) or state law ( $q \bar{a} n \bar{u} n)$, with the sacred scriptures of the Druze also apparently having little by way of binding guidance to offer.

The interviews illustrate that a diverse range of relationships between "speakers" and members of their presumed previous-life families can exist. Some "speakers" are reluctant to initiate contact with their families from their previous lives (as in Case J) or are rejected after seeking out their families (as in Case $\mathrm{H}$, where the nattiqa was rejected by her previous mother). Speakers may be accepted by some family members, while others remain sceptical (such as the brother in Case F). But these were flanked by many other cases in which remarkably close relationships between "speakers" and their previous families developed, so that the "speakers" spend certain periods of their lives (back) with their families from their past lives or even (like the nâtiq in Case C, who built a house directly adjacent to the home of his previous family) opt to live out their lives alongside their previous families. From an ethnosociological perspective, the relationship constituted by nuṭ in such cases could be described as an extended family: Each family has its own kitchen, but the garden is shared, and both families see each other most days. The description given by the interview 
partner in Case B of the family relationship being sustained even by subsequent generations in both families after the death of the "speaker" is exceptionally remarkable from the perspective of kinship studies.

Although the Druze today are not, genealogically speaking, a patrilineal tribal society in the understanding of classical ethnological theory (cf. Khoury and Kostiner 1991; Dostal 2005a; Chatty 2016) and often consciously distance themselves in their discourse from nizām al-qabalī, the "classic" tribal system, the consciousness that kinship is not necessarily limited to scientific-biological kinship or defined only in terms of consanguinity that is generally prevalent in Middle Eastern societies also seems to be significant for $n u t q$ cases: Kinship genealogies are not fixed and immutable in this view, but ultimately a product of negotiations and social processes or an outcome of conflict resolution processes (see the concept of "structural amnesia"; Dostal 2005b).

Cases of kinship constituted by nutq have some obvious parallels with the classical Arabian concept of milk kinship ( idi $^{-} a$ ), at least in terms of the resultant marriage prohibitions. Being breast-fed by one and the same mother makes children milk siblings (ikhwa bi-r-ridāa) who may not subsequently marry each other. ${ }^{29}$

The kinship ties described in the interviews are, finally, also plausible or explainable in light of the common practice of adoption in the Middle East.

29 Having children nursed by women who were not their mothers was, at least in former times, a common practice in the Middle East and one that was not always dictated by medical necessity. Having children breastfed by mothers considered to belong to a different ethnic-religious group is thought to have been quite usual. The concept of milk kinship and the marriage taboo it creates is known in both Judaism (see Chapman 2012) and Islam. A hadith has it that the prophet Muhammad said: "arRidāa a tuharrimu mà tuharrimu l-wilāda" - What is haram through birth is haram through breastfeeding and Sura 4, Verse 23 of the Qur'an itself states that "your mothers who nursed you" and "your sisters through nursing" are haram (forbidden [for marriage]). For a discussion of the topic from the perspective of social anthropology, see, especially, Altorki (1980) and Parkes (2005) who both use the term milk kinship to describe these kinship ties. When I raised the issue of similarities between $n u t q$ and milk kinship in an extended conversation with an interview partner, he confirmed that the kinds of kinship thus founded were comparable in principle but added that the incest taboo established by nutq was even more grave: While today some people may not worry too much about possible milk bonds and - if their love is strong enough - might manage to disregard them, marriage to "one's own sister" [i.e. a previous-life sister] would be unimaginable, if only for emotional reasons alone! (OeAW Phonogrammarchiv, Signature 20170707.G001). 
"Speakers" can be integrated (or reintegrated) relatively smoothly into their previous families, albeit more in the sense of customary law with its rights and duties (including marriage obligations and prohibitions) than as legal subjects before the state.

Integration versus distancing: Two opposed modes of constructing kinship constituted by nutq

Two contrary modes of approaching the construction of kinship relations in nutq cases can be discerned when one examines the interview excerpts and other cases that were documented during the research project:

(1) A "speaker" and their present family can seek and maintain proximity to their previous family, or this can happen in reverse, with the previous family seeking the "speaker's" proximity and attempting to reintegrate them into the family. We can subsume these outcomes under the heading of the "integration mode".

(2) A "speaker" and their present family can attempt to keep their distance from the "rediscovered" family, or the previous family can attempt to keep the speaker at a distance in what we can call the "distancing mode".

The question of when which mode is triggered and what incremental distinctions are made by individual family members can ultimately only be answered empirically on a case-by-case basis. However, the tentative analysis below seeks to pinpoint some shared characteristics of cases in which more or less all the involved parties approached one another in the integration mode and a kinship relationship that feels "genuine" emerged. A few working hypotheses derived from the data are sketched out below.

Working hypothesis ${ }_{1}$ Geography: The integration mode arises more frequently among the Druze in Israel

The likelihood of nutq cases leading to "closeness and integration" is considerably higher in northern Israel than in Lebanon and Syria. This is, at least, the conclusion that presents itself when all the cases documented during the research project are classified by nation-state context. While generalisations from the perspective of social anthropology are inevitably risky, it may be worth pointing out - simplistically, perhaps - that the Druze population in Israel forms a highly closed society (that typically demarcates itself clearly from the Sunni Muslim and Christian Palestinians in the West Bank and the Gaza Strip as well as from the Jewish population of Israel) that is also highly dispersed and lacks a contiguous settlement area. In contrast to the Shūf mountains (in Lebanon), Suwaydā' (in Syria) or - with some limitations the Druze settlement areas in the mount Hermon border region, the Druze of Upper 
Galilee in Israel live in isolated Druze villages or towns. Their settlements appear to be connected to one another primarily discursively, with the discourse on nutq playing a particular role. ${ }^{30}$

\section{Working hypothesis ${ }_{2}$ Families: The integration mode is more common in families with previous positive experiences of the phenomenon of $n u t q$}

Both the cases documented in the research project and the normative statements made by our interview partners permit the conclusion that the phenomenon of nutq occurs in certain family groups and certain villages more frequently than in others. ${ }^{31}$ The interview partners explained this by suggesting that some families pay more attention to children starting to "speak". It takes a certain level of awareness, they considered, for parents or other family members to listen attentively when children of two or three are learning to talk and start to speak - initially indistinctly - about people, circumstances and experiences in their previous lives and/or to display characteristics carried over from previous lives. People who have already had positive experiences with nutq in their own lives or in their families are, they believed, more alert to what their children are telling them and more likely to investigate any information supplied by children without delay. Our interview partners thought that such families encourage children - deliberately or subconsciously, overtly or subtly - to tell them more about their previous lives and that they support their children's search for previous relatives actively. They also seek to make their children's stories widely known, our interview partners told us, with "good intentions" of enabling the children to contact previous families - the first prerequisite for realising a successful and socially recognised 'amaliyat an-nutq in the integration mode.

Working hypothesis ${ }_{3}$ Case content: The integration mode is deployed when "speakers" do not present a major threat to members of their previous families

The previous-life brother who had treated a "speaker's" widow badly and felt entitled to keep her widow's pension for himself (in Case F), the mother who did not want to hand over gold and jewellery she had appropriated after the death of a "speaker" (in Case $\mathrm{H}$ ), the father whose extra-marital relationship was known to and ultimately revealed by a "speaker" (in Case I): What these people all have in common is that the sudden appearance of a "speaker" led to them being confronted - at least latently with accusations and therefore to them feeling inclined to reject the prospect of integrating a "speaker" as kin. But the narrated cases also show that these people isolated themselves by rejecting the "speaker" and that other family members can adopt differentiated positions in their relationships with "speakers". From an outside perspective,

30 This is also addressed in my final remarks at the end of this reader. For more detail on the social structure of the Druze population in the different nation states and the wider political outlook, see Tobias Lang's contribution to this volume.

31 'Abādìya in Lebanon and Bayt Jann and Jūlis in North Israel are, for example, particularly prominently associated with nuṭ cases. 
it seems that "speakers" represent a threat only to people who have got, as it were, skeletons in their cupboards. ${ }^{32}$

\section{Working hypothesis ${ }_{4}$ Case content: The integration mode is triggered when the relationship of the deceased to other members of the family was positive}

From the perspective of the previous family, a genuine "speaker" is not a stranger, but the deceased person and nobody else. When this person knocks at the door of the family home - in the body of a child - the integration mode can only be triggered if the family's previous relationship to this person was positive. During our data collection, we heard about cases of children being rejected because they had become morally culpable in their previous lives. One family, for example, refused to hand over money "discovered" in the context of a "speaker" supplying evidence to prove their case and argued that the deceased person had been a miser and that other family members had been entitled to the money to begin with. Characteristics ascribed to the deceased person or possible unsettled scores with the deceased seem to influence the willingness of previous families to enter into a kinship relationship in the integration mode with "speakers".

\section{Working hypothesis ${ }_{5}$ Case content: The integration mode is triggered when a "speaker" can positively identify with the biography of the deceased person}

From the perspective of a "speaker" analysing their room for manoeuvre between the options of integration and distancing, the specific biography of the deceased person seems to play an important role. When a "speaker" remembers being a criminal or an "evil" person in their previous life, the option of stepping into the shoes of the deceased and once more becoming part of the previous family is normally not pursued. The interview partner in Case J told us that he wanted to find closure on his previous life and not to step into it again, commenting that he knows exactly where the house from his previous life is located, but chooses not to initiate contact with his (previous) wife and daughters - ultimately because he is ashamed of his past life. "Speaking" children who can take up the threads of an honourable biography can, in contrast, increase their social capital significantly. The integration of a nattiq/a into the family of a deceased person represents the successful conclusion of an amaliyat an-nutq.

32 Fellow human beings who have behaved in a morally culpable way can be shown up in quite subtle ways by the appearance of a nattiq/a. See the notes in the section "Dynamite for families and retributive justice: The truth is uncovered by nutq!" towards the end of this contribution. In such cases, the self-interest of specific actors is often advanced as an explanation for the failure of the integration mode to materialise. 


\section{Conceptualised versus lived kinship: "Speakers" in double roles}

It is clear from the case studies (see Cases A, B, C, E, F, I) and from the conditions outlined in these working hypotheses that nutq cases can potentially lead to relationships understood as kinship ties developing in all their facets - including rights, duties, marriage prohibitions and an assortment of other consequences. The nature of such kinship ties and kinship practices will be examined somewhat more closely below:

From an epistemological standpoint, the kinship constituted through nutq is fundamentally different from the usual Middle Eastern kinship model in the sense that the "speakers" embody double roles in their personal identities. They are not merely related to their previous families, they are also members of these families - deceased and subsequently reincarnated family members. ${ }^{33}$

At the empirical level, the most obvious manifestation of this double role is that "speakers" have multiple names: People who knew "speakers" in their previous lives usually speak to them or about them using the names the deceased individuals were known by. From what our interview partners told us, it appears that the use of different names for one and the same person is approached in a laid-back fashion; "speakers" see it as "normal" that they are called different names by different people and that names from their previous lives remain in use. ${ }^{34}$

Interestingly enough, similarities or correspondences between a "speaker's" present and previous names are often pointed out. The nătiq in Case A observed, not without pride, that the name his parents had given him in this life was identical with the name of his beloved son in his previous life $\mathrm{e}^{35}$ - although his present parents could not yet have known anything about his kin from his previous life when they chose the name for him. The comments that such correspondences are hardly coincidental and the way they are narrated often

33 See Lorenz Nigst's contribution (in this reader) for more on the theoretical difficulties this throws up.

34 In Middle Eastern societies more generally, it is quite usual for a person's name to change multiple times during their lifetime (after the birth of a firstborn son, for example) or for the names used to change depending on the relationship between the participants in any given interaction (and its basis in, say, kinship, social ties or religious connections). This may explain why "speakers" do not see anything especially abnormal in being called different names by different people.

35 After the birth of his son, his own name would also have been derived from his son's name ("Abū ...", father of ...). 
give them the character of an additional form of proof that the nạtiq must indeed be the deceased person.

Apart from the symbolism associated with the use of particular "crossgenerational" given names, titles like y $\bar{a} m \bar{a} m \bar{a}$ are also used (and sometimes reversed, ${ }^{36}$ as is common in colloquial registers in Greater Syria) and previouslife relatives are treated in the same ways as present-life relatives.

The authenticity of the kinship relationship constituted by nutq was often underscored in the interviews by the roles taken on by "speakers" during ceremonies $^{37}$ - like funerals and weddings - marking major life events. In Case E, for example, the nätiq carried the coffin at the burial of his previous wife (as was appropriate for a "true" widower). In Case F, the nattiq effectively took on the role of the father of the bride at the wedding of his daughter from his previous life, and the nätiqin in Cases A and C made similar reports. But the English teacher in Case $\mathrm{F}$ also highlights the ambivalence and the difficulties engendered by him stepping into the shoes of the bride's deceased natural father: At the wedding, he describes, he was not only the father of the bride but also the husband of his - surviving - wife from his previous life, a situation that was recorded in photographs and caused a certain amount of distress to his fiancée in his present life.

The status of nutq kinship as genuine kinship was often also underscored by people mentioning that nutq relatives of opposite genders are permitted a degree of intimacy, including physical intimacy, that would be unthinkable for people of opposite genders in the Middle East who are not related. This related to close hugging and kissing (see Cases B and F) and to being able to spend companionable hours alone with a previous-life spouse. Brothers, sisters, sons and daughters from a previous family could also interact with a nattiq/a in exactly the same way as is usual between members of the nuclear family (see, for instance, Case $\mathrm{H}$ ). This potential for proximity between nuṭ kin is, in turn, regulated by boundaries in the form of the bans on incest and marriage within nuṭ relationships.

36 "A child, no matter his age (from 0 to 95 years old) may be called mama by his mother, baba by his father, a'mmo by his uncle, khalo by his maternal uncle, teta by his grandma and jiddo by his granddad". See: The Title Reversal. https://365daysoflebanon.com/ 2016/01/11/the-title-reversal/ (accessed on 18 December 2020).

37 From the perspective of social anthropology, such critical life events at biographical transitions play an especially important role in the formation and maintenance of personal and collective identities; see Fartacek (2010: 141-156). 


\section{"Typical" problems with relatives as a hallmark of "authentic" kinship ties}

When people speak about their nutq relatives, joy and weary sighs are often not far apart. In Case I, for example, the interview partner mentioned that visiting her elderly previous-life mother could be exhausting because of her mother's constant laments and demands and her over-protective nature - complaints that may be typical in many mother-daughter relationships. The convoluted thought processes, discussions and arguments (and the risks of triggering lifelong disgruntlement) mentioned in Case $\mathrm{F}$ in relation to the thorny problem of determining which relatives should (or must) be invited to a wedding and who can (or should) be left out will also be recognisable to many families who have encountered them outside nutq contexts. Similarly, people taking offence at perceived slights and withdrawing from a family (as in Case $\mathrm{H}$ ) and inheritance disputes or clashes over money also reflect behaviour patterns that are common in interactions between relatives in the Middle East and more generally. Descriptions of such conflicts despite or because of all their tensions and friction - indicate the degree of proximity that can flow from perceived kinship ties.

An interview partner who works as a teacher in Bayt Jann (Israel) narrated a particularly illustrative case. ${ }^{38}$ She told us that one of her pupils was a nattiq and lived his everyday life in both his past-life family and his present-life family. On some days, one family picked the child up from school, and on other days, the other family came to collect him. The teacher remarked critically that the two mothers competed over which mother could best look after the child and cook the best meals. While this conflict carried out to the detriment of the child caught in the middle is tragic, this example also shows just how authentically nutq kinship can be lived. From a Western European perspective, such cases are also reminiscent of the typical potential for conflict immanent to patchwork families. ${ }^{39}$

38 Archived in the OeAW Phonogrammarchiv (Signature: 20170829.G001).

39 Just like conflicts between consanguine relatives, conflicts between nutq kin often centre around money or allegations that some people are only interested in financial gain. A case from the Shüf mountains in Lebanon was described to us, for instance, in which a nattiqa born into poverty had her third-level education financed by relatives from her previous family. Such cases were seen broadly positively, but interview partners sometimes perceived the opportunities they potentially posed for disadvantaged families to enrich themselves as problematic. The risk that somebody is "only" using "the nuṭ method" (țariqat an-nuṭ) to secure some advantage or other appears, therefore, to be a latent possibility in virtually every case marked by economically unequal circumstances. This concern is reflected in the firm assertion of the nätiqa in Case $\mathrm{H}$ that she was not interested in seeking any material advantage. 
Conflicts of interest versus value conflicts: The potential of nuṭ to bridge rifts between rival factions

Remarkably enough, the very cases in which an especially deep relationship developed are often cases that feature frequent mentions of previous enmity between families or localities now bound together by nuṭ (see Case E, for example). In some cases, it was even the nätiqin themselves who had been especially prominently involved in conflicts (see Case C). As an overview of the documented cases shows, such enmity appears to have flowed from conflicts of interests between families that were resolved through an 'amaliyat an-nutq. The families were thus enemies, but honourable enemies, as it were, who espoused similar norms and values.

As the observations below show, the potential for conflict resolution contained in $n u t q$ cases is emphasised especially in reflective discourses on the nature of the transmigration of souls among the Druze.

\section{Ambivalent, idealised and subversive discourses}

On moving from the empirical level towards an examination of these discourses and looking at general beliefs (semantic knowledge) about nuṭ and normative aspirations associated with the phenomenon, one uncovers a certain ambivalence as to whether children who begin to "speak" should be encouraged and adopted (or readopted) into their previous families.

\section{Critical voices motivated by concern for children}

While many interview partners made enormously positive statements (among them our interview partners in Cases A, B, C, E, F and - with some caveats also Cases G, H and I), some concerns and criticisms present within the Druze community were also aired. Intellectuals, more so than other people, and especially interview partners from Syria and Lebanon, did not question the existence of the phenomenon of nut $q$ but often emphasised that it would be better to spare the affected children from encountering their previous families. The children could otherwise be torn between their past and present lives and might break down under the strain; children could suffer if they were rejected by their previous families - whatever the reasons for this were - and children's present families could be wounded if children started to distance themselves from their families and, for instance, say, you are not my mother! to their birth mothers.

The problem was, our interviewees said, that the hand of time does not stand still and that previous adults who return as children are physiologically 
younger than their previous-life children. The gist of what critical interview partners told us was that all these circumstances create confusion and have considerable potential to engender conflict.

To spare those affected from these difficulties, these warning voices sometimes suggested that seeking to encourage children to forget their previous life stories could be preferable to supporting them in their "speaking". ${ }^{40}$

Euphoric statements on the significance of nutq for society as a whole: "Nutq brings people together!"

While some interview partners critically appraised nutq as a phenomenon with few benefits for affected individuals, almost all of them made euphoric statements about the significance of nutq cases for Druze society. People and families who had not previously been acquainted or who had been locked in conflict find common ground through "speaking" children, they told us, and having multiple families or enlarging one's kinship circle was fundamentally enriching. Our interview partners also pointed out that such processes also reinforced the cohesion of the wider Druze community. ${ }^{41}$

This decidedly positive view enjoys approval in the highest Druze circles, as became clear on several occasions, including that of an interview with the spiritual leader of the Israeli Druze, Shaykh Muwaffaq Tarif, who placed great emphasis on the potential of nutq to resolve conflicts and bind families together and was able to tell us about an entire series of cases with positive outcomes. ${ }^{42}$ Such cases illustrate the principle of the transmigration of souls, as we heard from all sides - and people believe that this is ultimately what makes the Druze community so strong.

40 Statements by "speakers" (including the interview partners in Cases A, B, F and H) that people who remember their previous lives cannot simply forget them (and could struggle for their entire lives to achieve a kind of mental equilibrium if their routes to their previous families were blocked) must be understood against the background of this discourse.

41 Cf. Oppenheimer (1980), Bennett (2006), and Kastrinou (2016).

42 Interview in August 2017, Jūlis, archived in the Phonogrammarchiv (Signature: 20170826.G002). See the contribution by Nigst (in the present volume) on the theological significance of $n u t q$, an issue that engenders some controversy among Druze clerics. 


\section{Dynamite for families and retributive justice: The truth is uncovered by nutq!}

Interview partners repeatedly emphasised that a form of retributive justice often seemed to be at work in nutqq cases: An 'amaliyat an-nutq can lead to crimes, murders, manslaughter cases and dubious "accidents" being cleared up. In some - often prominent - cases, the guilt of murderers was proven and confessions and watertight legal convictions ensued (see Case G). ${ }^{43}$

The flip side of this is that cases of nutq can also lead to the innocence of people who have been under a cloud of suspicion being confirmed, as in Case C: The friend who had originally been accused of murder was finally exonerated by the account given by the nattiq.

Interestingly, however, the moral conduct of an individual other than the $n \bar{a} t i q / a$ is often revealed in the course of an 'amalìyat an-nuțq. The extra-marital relationship of the nattiqa in Case I came to light in this way, for instance. The brother of the nätiq in Case F, who was mired in an embarrassing legal battle with the widow of the deceased, was also brought into an uncomfortable situation, as was the mother of the nätiqa in Case $\mathrm{H}$, who had allegedly appropriated her dead daughter's gold.

Injustices can seemingly also be avenged through nuṭ: In Lebanon, especially, we were repeatedly told about cases involving people who had abused their subordinates in particularly humiliating ways, ordering them about and "treating them like dirt", only to be reincarnated as "small", "dependent" children in the households of their former underlings.

Major political and societal issues like war, blood vengeance, land confiscations and religious fanaticism can also be addressed in subtle ways through nutq cases. Many of the cases narrated to us in Lebanon referred to the Lebanese civil war, for instance in the form of a nattiq who knocks at the door of a house and slaps the person who answers in the face because of their cowardly behaviour in a military operation (see Case J). Cases of a deceased man being reborn as the son of his murderer and going on to avenge the murder were occasionally narrated. One especially pointed narrative was said to have taken place in Bshatfīn, a locality in the Shüf Mountains that has been characterised by a conflict carried on between two clans for generations in accordance with the traditional principle of blood vengeance (tha'r). A man murdered during this

43 Cases like this are also described in the literature and occasionally even attract attention (and sensationalist reporting) in national and international news media (Fartacek 2017: 49). 
feud was said to have been reborn as the son of his previous murderer, to have felt persistent intense antipathy towards his father, and finally to have murdered him and several other male members of his present family during a round of negotiations.

Subtle discourses are also invoked in discussions of cases that refer to ethnicreligious segmentation and religious fanaticism. Narrations of nutq cases sometimes take on the character of ethnic jokes, as in the story of an especially devout Christian family in the neighbourhood of Shārūn (in the Shūf mountains) who allegedly had a child who had been a Twelver Shi'ite in their previous life. We were told by a grinning Druze tomb keeper that the child remembered their previous life and, much to the horror of their present family, continued to behave like a Shi'ite and to say Islamic prayers five times a day.

As the following contributions to this book show, nutq cases are always embedded in wider discourses on the transmigration of souls and divine justice. They also serve a more practical function as a resource for coping with life's challenges, which will be taken up again in some brief final comments at the end of this book.

\section{Literature}

Altorki, Soraya. 1980. Milk Kinship in Arab Society: An Unexplored Problem in the Ethnography of Marriage. In: Ethnology 19 (2): 233-244.

Bennett, Anne. 2006. Reincarnation, Sect Unity and Identity among the Druze. In: Ethnology, 45 (2006): 87-104.

Bonß, Wolfgang. 1995. Vom Risiko. Unsicherheit und Ungewissheit in der Moderne. Hamburg: Hamburger Edition.

Chapman, Cynthia R. 2012. 'Oh that you were like a brother to me, one who had nursed at my mother's breasts.' Breast Milk as a Kinship-Forging Substance. In: Journal of Hebrew Scriptures 12 (7): 7, 1-41. DOI:10.5508/jhs.2012.v12.a7.

Chatty, Dawn. 2016. Bedouin Tribes in Contemporary Syria: Alternative Perceptions of Authority, Management, and Control. In: Rabi, Uzi (ed.): Tribes and States in a Changing Middle East. London: Hurst \& Company, 145-170.

Dostal, Walter. 2005a. Introduction. In: Dostal, Walter and Wolfgang Kraus (eds.): Shattering Tradition: Custom, Law and the Individual in the Muslim Mediterranean. London and New York: Tauris Publisher, 1-19.

Dostal, Walter. 2005b. Tribal Customary Law of the Zahran Confederation in Southern Hijaz (Kingdom of Saudi Arabia). In: Dostal, Walter and Wolfgang 
Kraus (eds.): Shattering Tradition: Custom, Law and the Individual in the Muslim Mediterranean. London and New York: Tauris Publisher, 122-147.

Fartacek, Gebhard. 2010. Unheil durch Dämonen? Geschichten und Diskurse über das Wirken der Ğinn. Eine sozialanthropologische Spurensuche in Syrien. Wien: Böhlau-Verlag.

Fartacek, Gebhard. 2017. Rekonstruktionen von ethnischen Beziehungen, Widerstand und Krieg: Ergebnisse eines Interviewprojekts am Phonogrammarchiv der ÖAW. In: Binder, Susanne and Gebhard Fartacek (eds.): Facetten von Flucht aus dem Nahen und Mittleren Osten. Wien: Facultas-Verlag, S. 293-317.

Fartacek, Gebhard. 2020. Sensible Forschungssituation und Potential. Narrative Interviews mit syrischen Kriegsflüchtlingen aus methodischer und methodologischer Perspektive. In: International Forum on AudioVisual Research - Jahrbuch des Phonogrammarchivs 10: 88-104.

Fartacek, Gebhard and Lorenz Nigst. 2016. Conforming to and Breaking with Social Norms: Two Contrary Modes of baraka. In: Beiruter Texte und Studien (BTS), Band 122 (Special Issue edited by Ines Weinrich: Performing Religion: Actors, contexts, and texts. Case studies on Islam), S. 53-74.

Fartacek, Gebhard and Lorenz Nigst. 2019. The Ritual Efficacy of Baraka: Healing of Illness and its "Side Effects" for Interethnic Relations in Syria and Lebanon. In: Ian S. Mcintosh, Nour Farra Haddad and Dane Munro (eds.): Peace Journeys: A New Direction in Religious Tourism and Pilgrimage Research. Cambridge: Cambridge Scholars Publishing, p. 64-79.

Flick, Uwe. 2014. An Introduction to Qualitative Research. Edition 5. London et al.: SAGE Publications.

Joarder, Taufique et al. 2014. Meaning of Death: An Exploration of Perception of Elderly in a Bangladeshi Village. In: Journal of Cross-Cultural Gerontology 29: 299-314.

Kastrinou, Maria. 2016. Power, Sect and State in Syria: The Politics of Marriage and Identity Amongst the Druze. London and New York: Tauris Publisher.

Kastrinou, Maria et al. 2020. The Stateless (Ad)vantage? Resistance, Land and Rootedness in the Israeli-Occupied Syrian Golan Heights. Taylor \& Francis Online. DOI: 10.1080/21622671.2020.1743203.

Khoury, Philip Shukry and Joseph Kostiner (eds.). 1991. Tribes and State Formation in the Middle East. Berkeley: University of California Press.

Oppenheimer, Jonathan W.S. 1980. We Are Born in Each Others' Houses: Communal and Patrilineal Ideologies in Druze Village Religion and Social Structure. In: American Ethnologist 7 (4): 621-636. 
Parkes, Peter. 2005. Milk Kinship in Islam. Substance, Structure, History. In: Social Anthropology 13 (3): 307-329.

Prager, Laila. 2016. The Miracle of Rebirth: Stigmata, Transmigration, and the Remembrance of Former Lives in Alawi Religion. In: Kurz, Susanne et al. (eds.): Muslim Bodies: Body, Sexuality and Medicine in Muslim Societies. Münster: LIT-Verlag, 281-310.

Procházka, Stephan. 2002. Die arabischen Dialekte der Çukurova (Südtürkei). (Semitica Viva, 27.) Wiesbaden: Harrassowitz.

Robben, Antonius C. G. M. (ed.). 2004. Death, Mourning, and Burial. A CrossCultural Reader. Malden, MA: Blackwell Publishing.

Robinson, Michael D. and Gerald Clore. 2002. Episodic and Semantic Knowledge in Emotional Self-Report: Evidence for Two Judgment Processes. In: Journal of Personal and Social Psychology 83 (1): 198-215.

Schmidt, Siegfried J. 1997. Kultur und Kontingenz: Lehren des Beobachters. In: Müller, Albert et al. (eds.): Konstruktivismus und Kognitionswissenschaft. Kulturelle Wurzeln und Ergebnisse. Wien and New York: Springer, 173-181.

Schmidt, Siegfried J. 2003: Geschichten und Diskurse. Abschied vom Konstruktivismus. Reinbek: Suhrkamp.

Somer, Eli et al. 2011. Beliefs in Reincarnation and the Power of Fate and Their Association With Emotional Outcomes Among Bereaved Parents of Fallen Soldiers. In: Journal of Loss and Trauma: International Perspectives on Stress \& Coping 16 (5): 459-475.

Stevenson, Ian and Erlendur Haraldsson. 2003. The Similarity of Features of Reincarnation Type Cases over Many Years. In: Journal of Scientific Exploration 17 (2): 283-289.

Straub, Jürgen. 1997 Geschichten erzählen, Geschichte bilden. Grundzüge einer narrativen Psychologie historischer Sinnbildung. In: Straub, Jürgen (ed.): Erzählung. Identität und historisches Bewusstsein. Die psychologische Konstruktion von Zeit und Geschichte. Frankfurt am Main: Suhrkamp, 81-169.

Winkler, Hans A. 1936. Die reitenden Geister der Toten. Eine Studie über Besessenheit des 'Abd er-Rāḍi und über Gespenster und Dämonen, Heilige und Verrückte, Totenkult und Priestertum in einem oberägyptischen Dorfe. Stuttgart: W. Kohlhammer. 

Lorenz Nigst ${ }^{1}$

\title{
The Different Appearance of the Identical: Some Thoughts About How the Druze Discourse on Transmigration Connects Lives
}

\begin{abstract}
J'ay remarqué une chose que quelque pauvre qu'on soit, on laisse toujours quelque chose en mourant. ${ }^{2}$
\end{abstract}

Blaise Pascal, Pensées

\section{Introduction}

In the Druze ${ }^{3}$ communities of the Middle East, like in any other society, people are born, live and die. The Druze perspective on life and death differs from that of other groups insofar as they generally believe in the transmigration of human souls or reincarnation, which is commonly referred to as taqammuṣ. ${ }^{4}$ More specifically, Druze assert that a person's soul (rūh, pl. arwāh), ${ }^{5}$ at the moment of his or her death, moves into the body of a newborn, where it lives on as a different human being. ${ }^{6}$ The individual souls thus complete not one but successive sojourns in this world, with each individual life corresponding to only one life-circuit $(\text { dawr or } j i l)^{7}$ of a soul that was preceded, and will be succeeded,

1 Lorenz Nigst is currently working with the KITAB project, a project that has received funding from the European Research Council (ERC) under the European Union's Horizon 2020 research and innovation programme (Grant agreement No. 772989).

2 "I have come to realise one thing - that, however poor one may be, one always leaves something behind when one dies". Pascal (1683: 28).

3 For the Druze, see, for example, Oppenheimer (1980), Rivoal (2000, 2016a, 2016b), Armanet (2003, 2011), Bennett (2006), Firro (1992). For Druze theology, see, for example, de Smet (2007) and Firro (2011).

4 For socio-anthropological studies taking up the topic of taqammus, see, for example, Rivoal (2000, 2016a, 2016b), Bennett (1999, 2006), Armanet (2011).

5 The term nafs, pl. nufūs also is used, see, for example, Talī (2001: 16-17).

6 This is expressed explicitly in the Kitāb an-nuqat wa-d-dawä' ir: "idhā naqalat nazalat wa-idhā färaqat ittaṣalat”. See Seybold (1902: 31).

7 For these terms, see, for example, Talī‘ (2001: 17-18). Our Druze interview partners often used the translation "generation". For the term jīl, see also Yahyā (2002: 19). In the Druze scriptures, the term kawr (pl. akwār) also occurs, see, for example, Seybold (1902: 33). 
by innumerable other life-circuits. From the Druze perspective, manifesting in a different form in each of its life-circuits, an identical soul thus "is" someone now, "was" others in the past and "will be" yet more others in the future. The person who is alive as a soul's current manifestation is dead as the soul's previous manifestation; the person who corresponds to a living member of one group as the soul's current manifestation is another dead member of another group. There is thus an objective relation between the successive, transient human beings as whom an individual soul completes its life-circuits. Their lives somehow are "connected".

The Druze discourse on taqammus, in all of its complexity, rotates around that perception. Druze have their ideas with regard to these connections, including the reasons why the soul transmigrates to a particular body (divine justice) or from where to where it migrates (within the confinements of the confessional and gender group). But many people have more or less personal experiences of transmigration, notoriously, in the form of concrete cases of "speaking" (nutq). Children are mostly the ones to "speak" (nataqa) about a previous life as someone else who as a rule passed away "too soon", typically through accidents, lethal injuries, disease or murder. The "speaking" individual may "retake" his or her "previous-life" place in another family. In these cases, the continuous disappearance of individuals that "are" the soul in each of its successive life-circuits plays out as a double presence - through "speaking", an individual lost to death in a sense "returns" (see also Nigst 2019b). Cases of "speaking" are about living the connection (or in some cases, the fear thereof or the frustration of not being able to do so). Inevitably, they generate not only unique opportunities but also difficulties, such as reconciling someone's presence as both a living and a dead person. But such cases are crucial: When talked about and circulated, they feed back into and corroborate the general ideas about taqammus and its functioning (see Nigst 2019b).

The Druze ideas of what taqammus is constitutes the backdrop against which cases of "speaking" children make sense. Taqammus is an abstract and quasi-theoretical assertion (Bouveresse 2007: 233) or set of assertions regarding what transmigration is, how it works and which purpose it fulfils. In contrast to this assertion is the experience of reality it lays claim to, which logically is the experience of human beings situated in (social) space and time. ${ }^{8}$

8 For this point, see Boltanski (2011: 59): "Having a body, each individual is, of necessity, situated-first of all, as the phenomenology of perception teaches, in as much as she is located in a moment of time and a position in a point of space where events appear to her-but also, as we learn from sociology and economics, in that she occupies 
If life-circuit follows life-circuit, from the human perspective, the full line of these life-circuits is never visible and can never be overlooked in its entirety. Only when someone claims to remember a previous life is a small section of that line thought to become accessible.

If one were to write a biography of each of the human beings as which a soul manifests, one would state who they are, that is, one would touch upon their personal and social identity; one would gather memories of them and recount what they did and what happened to them, and so forth. The more abstract the discourse on transmigration, the more all of this recedes into the background. Conversely, the more, through "speaking", the focus is on particular and contingent lives, the more questions of personal identity, personal memories, etc. take the centre stage. Thus, in Druze discourse, transmigration of souls brings lives into relation from a complex mixture of human and nonhuman perspectives; it encompasses both thoughts about no-one in particular and reports about particular instances of "speaking" and human beings.

\section{Taqammus as a set of abstract assertions}

Druze discourse breaks up human beings into a (perishable) body and an (eternal) soul. However, it also brings body and soul into a highly distinct and close relationship. Druze scholar Zayn ad-dīn 'Abdalghaffār's (d. $1557 \mathrm{CE})^{9}$ "book of points and circles" in this process, Kitāb an-nuqat wa-d-dawä ir, perhaps constitutes the best vantage point in this respect. Reflecting on the relation between body and soul, "Abdalghaffār states that the body is the "veil" (hijāb) of the soul through which the soul, at the same time, "manifests" and "hides". ${ }^{10}$ This fundamental idea is the context in which transmigration operates. The individual manifestations of a soul are related in two ways: a relation of identity of the soul and a relation of difference of the manifesting bodies. More specifically, a relation of identity is "hidden" behind the "manifest" relation of difference. Any claim regarding the identity of the soul in its successive manifestations is a claim about something that is there in the form of difference. Furthermore, in the Druze view, the soul is always in a body. ${ }^{11}$ It "cannot exist outside a human

a social position and has interests; finally, if we follow psychoanalysis, in that she has desires, drives, dislikes, an experience of her own body, and so forth. It follows that each individual can only have one point of view on the world".

9 For 'Abdalghaffār, see Firro (2011: 95-97).

10 For similar ideas in other theological contexts, see, for example, Carbó (2004: 3).

11 See Seybold (1902: 30-31). 
body"12 and is in constant "need of a body". ${ }^{13}$ It cannot function as a moral agent without the body ("lā taksibu khayran wa-là sharran illa bih $\bar{\imath}$ ), ${ }^{14}$ and it feels, acts, comprehends and so forth only through the body. It is a part of the world in and with the body. ${ }^{15}$ This need of the soul for a body surfaces in the Druze explanations of how transmigration works insofar as Druze often emphasise that the soul leaves the body immediately ${ }^{16}$ after death and "as fast as the electric current runs through a wire"17 moves to the body of a newborn. As a result, departing equals arriving, ${ }^{18}$ and birth and death are only "front and flipside of one and the same reality" (Armanet 2011: 150). ${ }^{19}$ This is reflected in the prevalent Druze claim that the dying breath of an individual always corresponds to the first breath of a newborn ${ }^{20}$ - "not one breath gets lost", as Shaykh Salmān alMișrī puts it. ${ }^{21}$ Thus, from the Druze perspective, the soul cannot not manifest, and the individual human being is only the current manifestation (zuhūr; pl. $z u h \bar{u} r \bar{a} t)$ of a soul, which has manifested in a myriad of different bodily forms before its current life-circuit and will manifest in a myriad of different bodily forms after its current life-circuit. Remaining identical in itself, the soul takes on, or moves, from one transient bodily form to another and this way completes its successive life-circuits (see also Firro 2011: 88).

These two key elements of "manifestation" and "migration" are reflected linguistically in Druze discourse. The lexeme taqammuș, normally used to express

12 See Firro (2011: 88).

13 See Seybold (1902: 30): "ihtiyāj an-nafs ilā l-jism"; the soul is in constant need of the body "lā tastaghnī 'anhu tarafat 'ayn”. See also BNF Arabe 1436, 30r: "[. . .] dhâtahā mawjūda fì badan jusmānī là tufāriquhù abdan bal kullamā dhahaba badan intaqalat ilā badan ākhar".

14 BNF Arabe 1436, 30r.

15 See also Zayn ad-dīn 'Abdalghaffār's Kitāb an-nuqat wa-d-dawā’ ir where he explains that the soul cannot act, imagine, think (etc.), without the body. See Seybold (1902: 30).

16 "Fawran wa-dūna nqițā"; see https://www.youtube.com/watch?v=Kp_kNBIyykc (accessed 19 April, 2018); min 01:16 ff; see also Talī' (2001: 19): “dūna ibțà”".

$17 \operatorname{Talīi}^{\prime}$ (2001: 17).

18 See Seybold (1902: 31): “idhā naqalat nazalat wa-idhā fāraqat ittaṣalat”.

19 See also Rivoal (2000: 382).

20 See Nigst (2019a).

21 https://www.youtube.com/watch?v=Kp_kNBIyykc (accessed 19 April 2018); min 01:24 ff. For the notion that the soul enters the body through the mouth after birth, see also Seybold (1902: 31): "ammā wurūduhā 'alā l-jism fa-tashruqu 'alayhi ba'da khurūjihì min baṭn ummihì ilā fasīh ad-dunyā wa-tadkhulu mina l-fam”. 
the notion of "transmigration" in Arabic, is semantically related to the Arabic noun qamīṣ (pl. aqmișa), which denotes an "envelope", "vestment" "shirt". More specifically, taqammus is the verbal noun of the Arabic verb taqammașa, the literal meaning of which is "to put on a shirt" or "to wear a shirt". ${ }^{22}$ In the context of transmigration, qamiss, in principle, denotes the individual body ( jasad, pl. ajsa $\bar{d}){ }_{.}^{23}$ In one regard, the term is connoted with the "mortal body", or even the "corpse", which is left behind when someone dies. This is tantamount to devaluating the transient body in comparison to the eternal soul (see also Rivoal 2000: 352) ${ }^{24}$ Just as someone wears a shirt and replaces it when its time is up, the soul puts on a body and wears ${ }^{25}$ it until it is destroyed and immediately replaced by a new, different body, which corresponds to the beginning of a new life-circuit. As one of our interview partners said with regard to this belief, the Druze are forever "to be continued" - like in an endless TV series, there will always be another episode. In the words of another interview partner, Druze souls were continuously "recycled". ${ }^{26}$

In another regard, the term qamis is connoted with "manifestation" in the sense that the body (qamis of the soul) appears before people's eyes, ${ }^{27}$ or the

22 See also Talī' (2001: 11) where taqammaṣa is explained as labs al-qamiṣ.

23 Needless to say, synonyms are used such as jism (pl. ajsām) or badan (pl. abdān). Some people also use the term qālib for body. This term is clearly connoted with the notion of "outer form" or "vessel" as is best reflected in the lexical pair qalb/qälib.

24 For the notion of an eternal soul see also Talī' (2001: 11). With regard to the lexeme qamīs in the sense of "body", the Rasä'il al-hikma contain a fascinating passage where the fellow believers are warned against fearing the destruction of their bodies. Literally, the passage speaks of tamziq aqmisatihim, the "tearing up of their shirts". The full passage reads: "Al-hidhr al-hidhr an takūnū mimman yakhshawna 'alā tamzīq aqmișatihim wa-ghaybat șuwarihim fa-yūqi'u bihim mawlähum mà yakhshawhu wa-yahdharūhu dhālika li-qillat thiqatihim bi-mawlāhum wa-khashyatihim min 'abìdihì'. See Rasä'il al-hikma, no. 35.

25 See Tali' (2001: 11); see also BNF MS Arabe 1429, 83v.

26 While insisting that taqammuṣ affecs humanity as a whole, people often talk about the phenomenon as if it affected only the Druze - which reflects that, in terms of a real presence of transmigration in community discourse in the sense of a shared belief that makes people do certain things, taqammus is for the most part limited to the Druze communities.

27 In contemporary Modern Standard Arabic, the expression taqammașa shakhșiyyat $X Y$ means "to impersonate someone". The common element with taqammus in the sense considered here is palpable. It is about "putting on" some outer appearance or personality behind which something else disappears. See, https://www.youtube.com/ watch?v=J_lp647E19A (accessed 17 April 2018). 
manifest form (șurra; pl. șuwar) something has taken on, which is at once hidden by that form. The Epistles of Wisdom (Rasä il al-hikma), for example, explicitly speak of "manifestations of different form" (zuhūrät mukhtalifāt aṣ-șuwar) in this context. ${ }^{28}$ In essence, this latter understanding of qamiș reflects the cyclical conception of history propagated in the Druze scriptures with their characteristic doctrine that something identical manifests in different bodily forms, or "shirts", in different epochs. ${ }^{29}$ As such, the term is of considerable conceptual importance in Druze thinking.

The conceptual element of "migration" is referred to by lexemes derived from the Arabic root $n-q$-l, such as intiqāl, nuqla or naqliyya. ${ }^{30}$ In particular, intiqāl al-arwäh (the "souls' change of location") is a common expression which people use to refer to transmigration. Similar expressions such as taqammus al-arwāh or, to a much lesser extent, tanāsukh al-arwäh occur. ${ }^{31}$

In the sense outlined above, taqammuṣ corresponds to a discursively claimed reality - it simply is the way things are thought to work. Human souls complete successive life-circuits, and one identical soul migrates from one body to another; the qamiss simultaneously "manifests" and "hides" that soul. Looking at two different things thus may mean looking at the same thing in two different forms. Transmigration produces life-circuit after life-circuit, and the individual manifestations are transient and perishable. In a sense, every human being objectively is a return of a soul in different form. This reality, which one "knows" to be the case, may be represented schematically as follows:

28 See Rasä'il al-hikma, no. 67.

29 The Druze hold that the five hypostases ( $h u d \bar{u} d)$ which form the centre of their cosmological recit, manifest in different forms. It is explicitly stated in the scriptures, for example, that God moves the universal intellect ( $a l$-'aql), His first creation, into every epoch and time with a specific name and specific qualities: "qāla aydan 'an il'aql al-kullì șalawāt allāh 'alayhi yanquluhu l-mawlā subhānahū fì kull 'aṣr wa-zamān bi-sm wa-șifa", Seybold (1902: 33). See also Firro (2011: 88).

30 See also https://www.youtube.com/watch?v=yKaVQ15AljA (accessed 15 May 2018); $\min 02: 28 \mathrm{ff}$.

31 Most Druze reject the term tanāsukh for taqammus. The reason seems to be that tanāsukh is connoted too strongly with theological propositions they reject, most notably the 'Alawi one that souls can migrate to non-human bodies. See, for example, Talī' (2001: 12). For this point, see also Bennett (1999: 93). For the 'Alawī view on transmigration, see, for example, Prager (2016). 


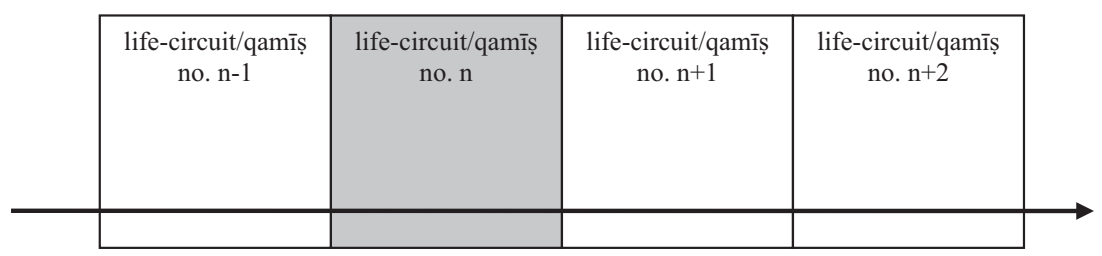

Fig. 9: Movement of the soul through its successive life-circuits. Graphics: Lorenz Nigst, 2020.

The key elements outlined above occur regularly, and more or less completely, when people explain the meaning of the term taqammus, with our interview partners being no exception. ${ }^{32}$ The Druze perspective, that two different things might be the same thing in two successive outer forms, creates unique possibilities and difficulties. If the same soul manifests through different bodies, this establishes an objective relation between successive human beings and lives. In the mind, these can be placed side by side to form a line of human beings, or lives, that somehow seem to belong together. This raises questions. Most notably, why did the soul move from just this body to just that body? Does all this serve a purpose? Is the individual itinerary completely random, or does it follow a certain logic?

\section{Why do souls migrate? The discourse of divine justice}

From the perspective of situated human beings, the successive life-circuits completed by a particular soul are neither synchronously present nor equally knowable. The reasons that inform a soul's itinerary must remain obscure.

32 Online, see, for example, https://www.youtube.com/watch?v=r2DMK0YSfj8 (accessed 15 May 2018), min 07:53 ff; https://www.youtube.com/watch?v=yKaVQ15AljA (accessed 15 May 2018), min 02:33 ff.; https:/www.youtube.com/watch?v=Kp_kNBIyykc (accessed 09 May 2018), min 01:09 ff. (“intiqāl ar-rūḥ min jasad ilā ākhar ba'd almawt"). See also Tucker and Roberts (2008: Vol.1, 306): "the rebirth of souls in a new body”. For more complete explanations, see Swayd (2006: 162), or Bennett (1999: 93). Note that the Druze also understand the relationship between soul and body through other metaphors, most notably the soul as leaven passed along when making bread (see Armanet 2011: 127 ff.). For many of our interview partners, reflecting upon taqammus was an occasion for much wider thoughts about what life meant. Owing to the fact that taqammuṣ is linked to the Druze cosmology, according to which all that exists emanates from the universal intellect, there is ample room for thinking beyond the limits of one's own existence, or casting a different light on the latter. 
Significantly, some Druze explanations of transmigration substitute the human perspective with a divine one, from which all successive life-circuits are known and can be connected in a stringent and reasonable way. More specifically, the claim that individual souls migrate to a particular body each time for a reason which is dictated by the principle of divine justice (al-'adāla al-ilähiyya) is pervasive (see also Nigst 2017: 64-65). Most notably, Druze often state that every soul has to pass through all conditions of life (jamī az-zurūfal-hayātiyya) and possible states (hālāt, sg. hāla), such as poverty, wealth, health or disease, ${ }^{33}$ in order for justice to prevail. In this dimension of the Druze discourse on divine justice, a soul's successive life-circuits as different human beings suffering, or enjoying, different living conditions are all trials (ikhtibār, imtihān) to which the soul has to be exposed for the final judgement passed on the soul to just be. Amin Țalī' asks: "Is it just that (final) judgement is passed upon a poor man while he has never lived in affluence? Or upon him who is sick and who never knew what it means to live in health? Or on a child who passed away before he or she could distinguish right from wrong, how could a final judgement be passed on him or her?” (Ṭalī 2001: 18).

In similar fashion, the peculiar working of divine justice is sometimes used to explain the seemingly random, and therefore potentially disruptive, distribution of coveted goods, living conditions, looks, etc. This apparently unjust and unequal distribution seems to make sense in the logic of transmigration that reaches beyond the limits of an individual lifetime and "evens out" apparent inequalities. ${ }^{34}$ This notion of divine justice is "additive". It is predicated on a totalising view from above, where all successive life-circuits can be seen together - and the reasons for the itinerary of the soul determined. More specifically, the relation between all life-circuits equals divine justice. Seeming injustices are simply the limited human perspective on divine justice as it materialises. The heart of the matter here is "moving on". Transmigration means that the soul leaves behind an old life and that innumerable new lives are lined up to be lived. What matters is that the soul has another, new life-circuit, in which it can live again. It was in that body then, but it is in this body now. It

33 See Talīi (2001: 19).

34 Members of the Druze religious establishment sometimes refer to this discourse. For example, Shaykh Mursil Naṣr writes in his book Ma'älim al-halāl wa-l-harām 'ind al-Muwahhidin "ad-Durūz" (2004: 224) that some people held fast to taqammus as a doctrine because they wanted "to solve some of the inconsistencies and questions that surround the apparent inequalities between people speaking in terms of intelligence, wealth, or health". 
had a chance then, and has a new chance now; it was a trial then, and is a trial now. In each life-circuit, the soul can, or cannot, relate to God.

Remarkably, Druze discourse also refers to a different notion of divine justice according to which people through their moral behaviour "make their own fate" across the boundaries of an individual life-circuit, as one of our interview partners put it. This view assumes causal chains that transgress the limits of an individual lifetime, opening up unlimited, but inexplorable, explanations for why a particular soul moved to a particular place where it suffers, or enjoys, a particular existence. The focus is on individual responsibility and accountability, and the body receives a function in the soul's requital for good and bad deeds that surfaces in the quality of life of the respective life-circuit. The notion of "debt" (dayn) is related to this: generally speaking, a gigantic metaphysical relay of causalities that allocates bodies to souls, lets bodies come about, decides where a given soul is going to move, etc. (see also Armanet 2011: 217-219). It seems that Druze discourse thus encompasses a retributive notion of divine justice, where present suffering is caused by previous acts.

It is worthwhile underlining that the retributive notion of divine justice surfaces in historic Druze discourse in the context of "proving" the existence of taqammus because the latter is utterly unobservable in itself ("intiqālhā fì l-abdān amr khaf $\vec{\imath}$ "), as is underlined by the Kitäb an-nuqat wa-d-dawä ir (Seybold 1902: 32). Thus, even those who believe in transmigration always arrive "after the event" and are confronted with its "result" (i.e. human beings). Prima facie, nothing about a human being suggests that his or her soul was "somewhere else" before, and the claim that souls transmigrate requires justification. Mobilising an array of premises, proofs, life experiences and the authority of the Druze scriptures to make the claim that transmigration actually occurs (see Seybold 1902: 32-33), the author of Kitäb an-nuqat wa-d-dawä ir states that some phenomena in the world do provide evidence for taqammus; otherwise, the premise that God is just could not be upheld. Most notably, the suffering of children is perceived to be indicative of previous sojourns of the same soul. Children have not committed anything in their young lives that would require punishment, so upholding the premise of divine justice requires assuming that a soul is suffering in the body of a child to atone for acts perpetrated in a previous life when he or she was an adult. ${ }^{35}$ Similar statements were occasionally made by our interview partners.

35 See Seybold (1902: 30): "haythu anna r-rabb 'ädil wa-ajrā al-jazä bi-l-khayr wa-shsharr 'alā l-ghayr bāligh wa-laysa lahu' 'amal hàdir yastahiqqu' alayhi l-jazà fa-dulla min dhālika anna lahū 'amalan sābiqan fì ghayr al-jism al-ḥădir'. 
Trust in the working of divine justice and the sense of things at a higher level is sometimes commended as an ideal by Druze when they reflect on inexplicable suffering and inequalities that do not involve them emotionally. At an abstract level, this ideal stance may offer an altered perspective on suffering and conflict that relativises the importance of the transient human beings involved. This stance does not always work; and the less it works, the more the focus is on the particular human beings related to oneself. The more these human beings disappear in an unexpected and tragic way, the less the detached stance that focuses on the necessity of what happens seems to work (see Nigst 2019b). By definition, transmigration is not only about manifestations but also about human beings in social space - about people who belong to families; beloved human beings. Accordingly, it also brings human beings into relation; they not only take their places in society, but one maintains emotional bonds with them and has memories of them.

\section{Where do souls migrate to and from? Bringing human beings in relation in society}

In one of its dimensions, the claim that the soul cannot not manifest and is always in a body (see Talī 2001: 16-17) looks at the human body in an instrumental light, emphasising that the soul with the body not only relates to God but also perpetrates neither good nor bad actions except through the body. From this perspective, human beings are not considered in terms of their places in the social world. Yet they take their places, regardless of which metaphysical logic is assumed to have caused a particular soul to migrate to a particular body. Druze discourse thus necessarily has to address the issue that transmigration de facto establishes a connection between human beings with a place in the social world. There is always that which Isabelle Rivoal has called "l'individu social, particularisé" (Rivoal 2000: 382). In this context, it is important to understand human beings take their place in society in different modes. ${ }^{36}$

Luc Boltanski's study on abortion offers important conceptual tools to explore this problem. The Foetal Condition focuses on engendering - "that is, the creation of new human beings who come to take their places in a world inhabited by already-present living beings and also by the memory of the dead" (Boltanski 2013: 24). Based on "different manners of treating and considering

36 For the following passage, see Nigst (2017: 59-61). 
human beings" (Boltanski 2013: 39), Boltanski proposes that people do not just take their places in society because they belong to different categories or groups, but each must "constitute a singular being, that is, a unique being for whom no other can be substituted" (Boltanski 2013: 28). Engendering thus requires "producing beings that can be singularized" (see Boltanski 2013: 24). Processes of singularisation are essential for bringing about the personal identity of a human being, that is, the fact of being identified individually "without any possibility of being confused with another" (Boltanski 2013: 28-29): "[T]here is no society in which human beings are not objects of a process of singularisation that assigns them one or more names designating them specifically as individuals, and that offers each one a unique place in a ordered set (most often in a kinship system)". As such, processes of singularisation must be distinguished from the processes of forming a human being's social identity. These are not about bringing about a singular place but about recognising that one has something in common with others or belongs to the same group. As a result, there are "two modes of grasping human beings in society", the "general" and the "singular" (Boltanski 2013: 35). Each human being is constantly associated with equivalence classes ("generalisation") and singularised ("singularisation") - this is how "social life shapes the human condition" (Boltanski 2013: 36). One can be a "man", a "woman", a "Druze", a "child", "one-legged", "rich" and so forth; and one is the "Amjad", "Ashraf", or "Șafwān" and so forth, who belongs specifically to those people (with these names) and not to others. ${ }^{37}$ If taqammus creates relationships between human beings, who are the successive manifestations of

37 A passage which evokes several important elements with regard to having a place in the social world is contained in an epistle entitled Ar-Risāla al-mawsūma bi-l-asrār wa-majālis ar-rahma li-l-awliyä wa-l-abrār found in manuscript form in a volume of Druze scriptures held by the French national library (see BNF Arabe 1429, 83r ff; see also Silvestre de Sacy 1838: vol.2, $407 \mathrm{ff}$ ). While it is unclear how the epistle fits within the larger corpus of the Rasäil al-hikma, the passage spells out the idea that God, when creating the world, created it exactly as it is in the present (mithl mā tarāhu fì hädhā l-yawm), comprising "men and women, old men and young lads, old people, young people, children, thousands and thousands, in numbers that only He can count". This remarkable reflection on the fact that people have their place in the world suggests that God "made people see in their minds" (awrähum [sic] fī 'uqülihim) that they had fathers and grandfathers, professions or teachers. They visit graves, stating that the graves belong to a particular relative of theirs, or some other concrete person. They talk about teachers, trades, children, and so forth (see BNF Arabe 1429, 83r). 
the soul, when the soul migrates, it retains membership in certain categories, but each human being occupies different unique and singular places.

\section{Transmigration "from within": Unknown connections between a person and a place in society}

Transmigration objectively establishes a relation between all the human beings which, as manifestations of one identical soul, have taken their place in society. This raises questions about the social and personal identity of those human beings. Fig. 9 above does not literally illustrate the perspective of any human being. "From within", taqammus is experienced by agents who are necessarily situated in (social) space and time. Normally, people can only be related to one life-circuit of a particular soul, which is "current" for a particular human being and the people they influence or are influenced by, belong or belonged to. One "knows" that other lifecircuits have taken and will take place - as the abstract assertion claims ${ }^{38}-$ but, normally, that is all. Someone "knows" that his or her soul will be somewhere else, but that is all. Likewise, if a family loses a member, they "know" that the soul of their lost relative will transmigrate to another body, but that is all. People have neither a name nor a location nor any others details regarding the future place.

The same holds true for a family to whom a child is born. They "know" that the soul, which now manifests as their child, was someone else who now is another family's "dead", but they do not have any details as to who that person was, where he or she lived and so forth. In both directions - the future for those who have lost someone, the past for those to whom a child is born, there extends an unknown which, apart from the one's understanding of how taqammus. works, is largely impenetrable. Likewise, the human being in whom the soul is currently manifesting itself does not know who he or she was previously or will be in the future. Hidden behind the human being who one is or whom one knows or knew are entire worlds of life-circuits that are utterly unknown. Although, owing to the Druze idea that every death is only the flipside of a birth (see Armanet 2011: 150), taqammus conceptually involves a family which loses a member and another family to whom a new member is born - normally, the individual does not know who he or she was, the two families do know each other. ${ }^{39}$ The two different personal identities of the human beings

38 Druze Shaykh Bahjat Ghayth states: "I know through my belief that I existed [before this current life]" (ba'rif hatman bi-ìmānì innī kint). See https://www.youtube.com/ watch?v=2tEy3mjXD8s (accessed 17 May 2018), min 01:10 ff.

39 See also Haraldsson and Abu-Izzeddin (2002: 363-364). 
as which the soul manifests in the two life-circuits do not become enmeshed. Eléonore Armanet has shown that her Druze interview partners regarded newborn children as adults and as strangers who have been the son or daughter of someone else (see Armanet 2011: 151). This clearly relates to these worlds which are unknown to situated human beings. If only one life-circuit is known and accessible, except for knowledge gained through cases of "speaking" can nothing be said about the itinerary of the soul? Is there nothing more specific to say about those who died, those who live and those who will be born?

\section{From where to where? Predictions about a person's connections with a place in society}

It is characteristic of the Druze taqammus discourse to attenuate this unknown. It does so by claiming that there is some degree of predictability owing to permanent forms of group membership, that is, the social identity of the human beings as which the soul manifests in its successive life-circuits is thought to be determined, stable and predictable in important respects. More specifically, it is thought that membership of a gender and confessional group is permanent (see also Nigst 2017: 63-64). "Distinguishing between the sexes" taqu tammuṣ is deemed to operate in such a way that a soul will always manifest as a human being of the same gender; likewise, a soul will always manifest as a Druze, with the same holding true for Muslims, Christians, Jews and so forth. Conceptually speaking, this produces the effect that a soul is thought to be a part of the world constantly either as a "male Druze" (etc.) or as a "female Druze" (etc.) (see Nigst 2017: 62-64). For the most part, this is how taqammus is supposed to work and the resulting predictability of the soul's sojourn with regard to gender, and confession regularly forms part of the explanations of taqammus.. ${ }^{41}$ Apart from mitigating the lack of knowledge about a soul's identities apart from its current one, confining transmigration to the same gender and the confession, and minimising, if not explicitly denying ${ }^{42}$ changes of membership in these groups, also removes the potential that entirely "unregulated" transmigration would have to subvert some of the most deep-seated categories that structure the social world.

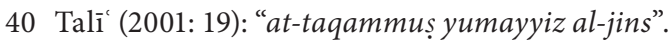

41 See, for example, https://www.youtube.com/watch?v=yKaVQ15AljA (accessed 15 May 2018); min 06:00 ff.

42 There are cases, (see Lațif 2014: 266-270); also https://www.youtube.com/ watch?v=XGN-TgQ-0iM (accessed 4 July 2017). 
Remaining within the boundaries of one gender and confession, the itinerary of the soul is claimed to respect two forms of categorical membership, both of which are considered primordial. Most notably, the perception that transmigration happens within the boundaries of one's own confession fulfils important conceptual or ideological functions. If Druze souls are thought to remain Druze, this constitutes a soul-based form of being related to each other (qarābat ar-rūh) and thus a unique form of cohesion (see Armanet 2011: 210215). This is the logical effect of the claim that the soul, in its successive lifecircuits, cuts across the boundaries of the familial groups to which each of its manifestations belongs and thus produces the effect that Druze are "born in each other's houses" (see Oppenheimer 1980). If one were to remove the idea that "Druze always stay Druze" and assume that the soul moves to any human being regardless of confessional membership, the connective effect of qaräbat ar-rū $h^{43}$ would be severely damaged. Instead of "consisting" of the same souls that joined the Druze in the eleventh century $\mathrm{CE}^{44}$ and remained Druze in all successive life-circuits, the Druze collective would be reduced to the assembly of those who are currently Druze. But if one thinks that Druze souls forever move within the Druze collective, the latter corresponds to the ever-changing manifestation of the same pool of souls. Every birth or death only changes the

43 Mobilising the terminology of kin, the term qarābat ar-rūh demonstrates how much the perception that souls migrate from one human being to another encompasses the perception of a real "connection" between those people.

44 On the contract ( $m \bar{i} t h \bar{q} q$ wali az-zamān) signed by each and every Druze when they joined the movement at the time of Hamza b. 'Alī, the central founding figure of the Druze community and manifestion of the universal intellect at his time, see, for example, Rivoal (2000: 32). For the integration of the original act of signing that contract in the religious and community life of the Druze, see, for example, Rivoal (2000: 150-151). The mìthāq wali az-zamān forms part of the so-called canonical scriptures (Rasä il al-hikma) and has been commented upon numerous times. One commentary, which is held in manuscript form by the French National Library, describes how the contracts signed by both the Druze/Muwahhidin and the apostates are kept in a safe place until the Day of Judgement: "wa-hädhihì l-mawāthìq almuktataba 'alā l-muwahhidina wa-l-murtaddina mahfūza fì amākin mahrūsa là tablā wa-lā tataghayyaru muṣāna bi-șiyānat rabb al-'ālamīna ilā yawm al-jazà' faidhā tajallā r-rabb ta' ālā yawm al-qiyāma bi-l-'azama wa-l-jalāl wa-hadara bayna

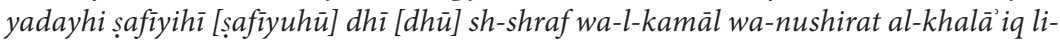
l-hisāb 'inda dhālika ya' dinu llāhu subhānahū bi-zuhūr al-mawāthīq mina l-amākin allatī fìhā l-än fa-tanzuruhā n-nās wa-kullu man kutiba 'alayhi l-mìthāq". For the passage, see BNF Arabe 1436, 7v-8r. 
current form of the collective. If the itinerary of that collective can be located because, in the long term, the transmigratory activity of the souls furthermore draws the map of where the Druze are.

Are there exceptions to this rule of immutability in gender and confession? According to both our interview partners and the scholarly literature, there are no known cases where taqammus crossed the gender boundary. Some of our interview partners, who were generally critical of the outlined forms of predictability, said that the idea that a "male" in this life-circuit always was and will be "male" in the other life-circuits might be shattered in the future (see Nigst 2017: 64). This implies that these interview partners see a societal influence on the cases which are reported. Regarding transmigration across confessional boundaries, the situation is less clear. It is plausible that most people deny that "Druze" souls cross the boundaries of the Druze collective. Again, there are exceptions. ${ }^{45}$

While some might simply accept them, it is worthwhile pointing to explanations for them, which rather explain them away. Leaving aside the theoretical problem that someone could have joined the Druze in the eleventh century CE in an act of hypocrisy and dishonesty, or turned his or her back on them, "errors" could happen - the soul simply ended up in the wrong confessional group by mistake. ${ }^{46}$ In both cases, a non-Druze soul transmigrates within the Druze collective.

Many Druze seem to insist that this erroneous group membership will end at some point because souls want to return to the group to which they truly belong (see also Rivoal 2000: 36). Significantly, they claim that this happens through marriages of Druze to non-Druze, where a supposedly "Druze" soul returns to where it actually belongs by transgressing the rule of endogamy. ${ }^{47}$ The thought that taqammus is susceptible to "errors" also occurs with regard to sex in one specific respect. Israeli Druze interview partners occasionally brought up the idea that homosexuality might be explained through "errors" during the process of transmigration, the idea being that, for example, a "male" accidentally

45 A passage in the novel Jasad kāna lī by Anīs Yahyā implicitly suggests that according to some, suicide pushes a soul away from being Druze for several life-circuits: "almuntahir yashqā fī șaqī' aḍ-ḍalāl țilat sab'at ajyāl dūn an yakūna 'indahū hạa z. bistizlāl shajarat at-tawhīd".

46 Personal communication by Maria Kastrinou to the participants of the workshop "Reincarnation and personal identity in the Middle East", 30 November 1 December 2017, Austrian Academy of Sciences, Vienna.

47 See also Rivoal (2000: 36). On endogamy, see Armanet (2011: 210 ff). 
ended up as a "female" in the next life-circuit, retaining "male" inclinations, which turn her into a lesbian. ${ }^{48}$

Manifestly, permanent membership of one gender and one confessional group is problematic with regard to the discourse on divine justice, which rests upon the premise that the souls must experience all states. The problem of what to do with a soul that constantly manifests as a "male" and never experiences being "female", or as "Druze" without ever having another confession, is for the most part skipped. This makes sense - whereas differences between "rich" and "poor" Druze are potentially disruptive, they can be transfigured into a requirement of how divine justice works. With its insistence that people get what they deserve, or have to be exposed to all states, a particular Druze discourse justifies the respective inequalities but does not shatter the perception that all are Druze. Logically, transmigration across the confessional boundaries implies that Druze can become non-Druze and vice versa, which would put an end to that unique form of cohesion based on membership of the same pool of souls.

This latter notion of taqammus, according to which Druze are always "reborn" as Druze, seems to have acquired central importance within the later (post-Rasä'il al-hikma) Druze tradition (see de Smet 2007: 66), plausibly due to historical developments. Originally a radically messianistic and antinomian (see de Smet 2007: 67-70) "missionary" movement shaped intellectually mainly by Hamza b. 'Alī from 1017-1018 CE onwards, which paid little attention to transmigration, the Druze "missionary" activity (da'wa; see the term iqfäl adda'wa; Rivoal 2000: 35; de Smet 2007: 67) was ended after roughly 25 turbulent years in 1042-1043 CE with the retreat of Bahäad-Dīn al-Muqtanā (see de Smet 2007: 34). From that time onwards, it was no longer possible to join the Druze movement (at least according to the Druze doctrine; historically speaking this does not rule out conversions). The reservoir of Druze souls was then closed (de Smet 2007: 67), and Druze were only those who had responded to the Druze da'wa between 1017-1018 and 1042-1043 CE ("illi mā 'abil barrä"). The idea of taqammus became increasingly important; it enabled preserving the idea of a closed community that formed in the first half of the eleventh century CE

48 The possibility of change from "male" to "female" and vice versa seemed to be a "taboo" subject and clearly sexually connoted. At least, the question prompted laughter on several occasions. For explanations of homosexuality and gender reassignment through the rūh al-hayāt among the 'Alawīs, see Prager (2016: 301). 
and perpetuating this community that has ruled out conversion (see Rivoal 2000: 33-34).

\section{From where to where? Connections becoming known through "speaking"}

In Druze discourse, the boundary between the previous and the present lifecircuit of one identical soul is always a little blurred. It is thought that for some time the soul clings to its previous life-circuit and is emotionally attached to it - "letting go" of the old life and growing familiar with the new life takes some time (see Nigst 2017: 77). This finds expression in a poetically developed element of sadness which Druze discourse associates with taqammuṣ. Taking up the pain of losing the place one loves (one's old life), it draws an analogy between "soul" and "bride" (see Armanet 2011: 248). While it is characteristic of the Druze to detect this form of attachment in everyday life, ${ }^{49}$ it is rare for the not-entirely-clear-cut boundary between life-circuits to surface more explicitly. ${ }^{50}$ People do not often speak about a previous life-circuit, refer to a particular personal identity that could be identified or have episodic memories that could be "verified". Consequently, life-circuits and personal identities normally do not overlap. People simply live their lives. Many people seem happy about this because the unknown worlds of their previous lives make them anxious. They do not want to know who or what they "were" in other life-circuits.

Regardless, it is an integral part of the social reality and experience of taqammus in Druze communities that in exceptional cases, souls do remember (tadhakkara) a previous life to the extent that those memories are verbalised. ${ }^{51}$ This happens in a phenomenon termed "speaking" (nutq) in local parlance. Typically, children aged two to four start to "speak" (națaqa/yanțuqu) about

49 Many interview partners explained to us that seemingly inexplicable behaviour of newborn children, such as unmotivated laughing or crying, made perfect sense against this backdrop (see Nigst 2017: 77).

50 It is rare with respect to the total number of transmigrations. This is not to say that cases of "speaking" are an extraordinary event in the Druze communities. On the contrary, every Druze can easily narrate cases he or she knows, and they flare up literally everywhere. Regardless, our interview partners stated that some communities have especially many cases, while others have no cases at all. The latter was claimed by interview partners about their village Ain Ksour in Lebanon in October 2016.

51 For cases mentioned in TV programmes, see, for example, https://www.youtube. com/watch?v=uN4levEgl0Y (accessed 1 June 2018) or https://www.youtube.com/ watch? $v=$ fr5T4TTBr6w (accessed 1 June 2018). 
previous lives which often ended unexpectedly or violently. ${ }^{52}$ In the Druze communities, such "speaking" children are referred to by the active participles nātiq (masc.) and nätiqa (fem.) - "he or she who speaks". Owing to TV shows, or to the celebrity of one of the individuals involved, some of these cases are widely known. ${ }^{53}$ According to our interview partners, "speaking" children must be understood as souls remembering and clinging to their previous life-circuit to such an extent that their current manifestation (the "speaking" child) claims to really be someone else (the individual who they were before that person passed away). As a consequence, the relation of difference that hides the identity of the soul is present in such a way that one family's living member claims to be another family's dead member. Considering that remembering and being able to refer to oneself in the first-person are "person-making characteristics" (see Quante 2002: 19-23), ${ }^{54}$ claiming a different personal identity and having memories of this are related.

Despite being only a subset of all cases, these instances of "speaking" have come to dominate the idea of what transmigration "is" for the Druze and the non-Druze alike. This is plausible as cases of "speaking" make taqammus "palpable" (shī malmūs). Through the often peculiar impression made by children who claim to be in the "wrong place" (see below) and the events these claims may set in motion, taqammus is "really there" (see Nigst 2017: 75-76). ${ }^{55}$ Because situated human beings have no knowledge regarding another life-circuit, "speaking" is the only case where the abstract assertion that souls migrate

52 Online, see https://www.youtube.com/watch?v=uN4levEgl0Y (accessed 1 June 2018, $\min$ 00:44 ff.) where a young woman says that as a child she referred to an accident that killed her in her previous life and to the surprise of her mother, said things like "Boom! Blood! Accident!" (Bumm, dam, hädith!). On violent death, see also Bennett (2006: 90-93); Stevenson and Haraldsson (2003: 286-287); Rivoal (2000: 350 ff).

53 For example, Lebanese TV star Raja Nasser Eldine, see https://www.youtube.com/ watch?v=5TnlGOody1 A (accessed 5 August 2017), min 02:00 ff.

54 For a recent philosophical contribution which contends that the episodic memory teaches us nothing at all about personal identity, see Sattig (2017).

55 This also shows in terminology. As implied by the term subset, every case of "speaking" (nutq) is a case of taqammus, but not every case of taqammuṣ is a case of nuṭ. Accordingly, every "speaking individual" (nāțiq) is a a "reborn individual" (mutaqammis), but the reverse is not always the case. Regardless, it is quite common in local parlance for people to use the terms nattiq and mutaqammis interchangeably, that is, they use the term mutaqammis in order to refer specifically to a nattiq. Grammatically speaking, mutaqammiṣ is the active participle of the verb taqammașa/ yataqammaṣu. 
produces palpable results. "Speaking" is also crucial insofar as it, for the most part, also corroborates the predictions made with regard to gender and confession. The phenomenon is sometimes characterised as "popular" by Druze intellectuals (zähira sha'biyya). It is certainly true that "speaking" is something the wider Druze population believes in ("yu'minu bihā 'āmmat an-nās min ad-Durüz"). ${ }^{56}$ Many cases of "speaking" furthermore seem largely independent of the religious establishment. It is worth stressing that, for theological reasons, (accessible) Druze scriptures explicitly dismiss the idea that a soul could remember a previous life. ${ }^{57}$ Obviously, this does not imply questioning transmigration as such.

\section{Connections coming to light: Annoying and odd dimensions of the "return"}

In the context of "speaking", a deceased individual in a sense "returns" in the form of the "speaking" child who claims to be that individual. Owing to the inevitable differences and discrepancies between the previous life and the current life, this "return" often has a certain oddity about it; the connection between two life-circuits and the double presence of a soul come to light in characteristic ways. Most notably, people mention the feeling of being "in the wrong place" (see also Bennett 1999: 88; Nigst 2017: 65-67, 2019a). Most important in this context are the age categories (see Stevenson and Haraldsson 2003: 286), considering that taqammus for the most part shifts previous-life "adults" to present-life "children". People talk about "speaking" children who find it annoying to be treated like children again because they (their souls) were "adults" in the previous life-circuit. They are reported to protest against wearing children's clothing or to be furious about what they perceive to be unseemly treatment, such as being reprimanded in public (see Lațif 2014: 194). Typically, "speaking" children may want back individuals who belonged to their previous "adult" life, such as husbands, wives or children.

56 See https://www.youtube.com/watch?v=euEbPA-3iaA (accessed 7 May 2017); min 21:38 ff. See also the expression "min thaqäfat ash-sha'b" used by one interview partner.

57 Not least, the Kitāb an-nuqat wa-d-dawä ir (Seybold 1902: 33) anticipates the question why souls do not remember other life-circuits if they have actually lived them: "in qāla qā'il mà lanā là nárifu mā maḍa min al-adwār wa-l-akwār qāla lmuhtajj bi-l-haqīqa...” 
Shifts with regard to other categories also occur. Taqammuṣ may cast a human being into another socio-economic status - according to the Druze claims that divine justice requires that an individual is exposed to all possible states, this must occur. Regardless, "speaking" children are said to complain about a lesser socio-economic status. ${ }^{58}$ They may come across as decidedly "unchildlike", and one can perceive the "adult" who has been transported back to being a "child" again (see also Laṭif 2014: 265; 275) through the way they speak, the language they use or their tone. Often, one can sense times long gone by because the language the "speaking" children use, or the things they like, are outdated ('ando shi min zamān). People sometimes report feeling that they are in the presence of a child who is not really a child, ${ }^{59}$ and "speaking" children are said to prefer to be among the adults they feel themselves to be. Some report skills one would not expect from children. ${ }^{60}$ Not least, there are numerous cases of inexplicable linguistic skills ("xenoglossy"). ${ }^{61}$ The Druze perception that taqammuṣ may shift memories, habits or skills that belong to a previous lifecircuit to the present also explains why taqammus, to a certain extent, allows for the integration of individuals that are "weird" - such weirdness makes sense as a form of behaviour that was "normal" in a previous-life circuit. Similarly, taqammus explains phobias ${ }^{62}$ or may take away the onus of justifying oneself for less "normal" predilections - dating back to another life-circuit, they are not really "one's own fault" ${ }^{63}$ In this context, people regularly bring up the possible influence of a previous life with regard to children who have not "spoken"

58 See, for example, www.annahar.com/article/395204 (accessed 29 November 2016). For example, children may claim that their old house was bigger or that they owned a much fancier car.

59 See https://www.youtube.com/watch?v=0_v2Pb9jopo (accessed 19 May 2017); min 35:00 ff; https://www.youtube.com/watch?v=0_v2Pb9jopo (accessed 19 May 2017); $\min 48: 50$.

60 Interestingly, people often mention knowing how to pilot an airplane. Boys' professions in the previous life often seem to be the ones which boys typically dream all over the world such as truck drivers, or caterpillar excavator drivers. Something children most certainly can identify with at that age.

61 Especially in Northern Israel, there seems to be a recent upsurge in such cases.

62 For example, someone killed by a fire in a previous life might be afraid of fire, or someone who died in a car accident might be afraid of reckless driving (Latîf 2014: 274).

63 One interview partner explained that she had already been a vegetarian in her previous life; another explained his preference for wearing his hair long with his previous life. 
but who seem to be especially bright or have learning difficulties. While such a "child" may never ever actually start to "speak", the perception that a previous life might be responsible for his or her extraordinary condition is "in the air" and those around the child discuss it, often extensively. ${ }^{64}$

However, cases of "speaking" are felt particularly strongly when "speaking" children refer to another personal identity and voice the much more profound complaint that they "are someone else". People tell about upset or crying children who claim that their current personal name is wrong, that their parents are not really their parents, that they live in the wrong house, that their real mother was more beautiful, and so forth; in short, individuals who want to return to their previous place.

\section{Finding out about the previous personal identity: The "return" of someone lost to death}

It is an integral part of the Druze experience and understanding of "speaking" that the personal identity of a previous life-circuit may become known and found out about. The "speaking" individual may "return" to a specific social place. Owing to either a conscious effort on the part of (one or both) of the families involved ${ }^{65}$ or to pure chance $(b-s-s ̣ d f a)$ when an individual at some point stumbles across someone ${ }^{66}$ or something from his or her previous life, which may happen later in life, ${ }^{67}$ "speaking" may lead back to the family in which the previous life was lived. The previous life may have been lived in a

64 For example, we visited a little girl and her family in Northern Israel in August 2017. The girl spoke English with a strong US American accent and was said to never have been exposed to the language enough to explain this linguistic skill. The people present were extremely attentive to her vocabulary, wondering whether individual words she used would give clues as to who she was before, which profession she had, and so forth.

65 Conscious efforts at identifying the other family were mentioned by our interview partners. For this point, see statements made by Druze Shaykh Sāmī Abī l-Munā in a TV appearance (https://www.youtube.com/watch?v=XGN-TgQ-0iM (accessed 7 April 2017), min 50:40 ff. A mother consciously looking for her lost son has been described in an article published in the Lebanese newspaper Al-Joumhouria, http:// www.aljoumhouria.com/pages/view/19492/2799 (accessed 19 May 2017).

66 This may include stumbling across one's own murderer.

67 One interview partner told us that by chance he saw and remembered the drive that led to his previous-life house. Another told how his little brother suddenly spotted his previous-life mother in the market. 
remote village or close to where the current life-circuit is lived. "Speaking" does not always or automatically lead somewhere. Parents may either stall the "speaking" of their child (see below), or their "speaking" children engage and identify with their previous life, ask them questions about it and encourage them to refer to that life, ${ }^{68}$ without establishing contact with the previous-life family, either because they cannot or are not sure whether they really want to deal with the consequences. ${ }^{69}$ That is, they claim to know who the others are but prefer to steer clear of them. Nonetheless, Druze communities experience that "speaking" sometimes leads to real-life relationships between the "speaking" individual and family members from the life that they claim to remember. More specifically, if contact with the previous-life family is established, contingent upon "proof" (see below), that family may recognise that the soul manifested in the "speaking" child is identical with the soul that manifested in the family member they lost to death, who in a sense has "returned". In this case, there are individuals who know who they "were before" and there are two families which know who their member was when he or she belonged to others in a previous life. Although such cases are the most notorious, sometimes even worldwide ${ }^{70}$ they are not the rule, but constitute a small subset within the cases of "speaking", which are a subset in themselves (see French 2016: 91). This situation, which jumbles up layers of time and corresponds to the double presence of one soul, is complex in manifold ways and raises many questions.

68 The impression that people encourage their children to "speak" also touches upon the question whether they make them do so. One interview partner in Northern Israel (in August 2017) explicitly stated lack of belief in taqammus and insisted that his nephews, who both "spoke" about previous lives as children, originally had no memories at all and did not "speak" but were enticed to do so by their father. This interviewee was remarkable as he broached topics which were systematically denied by others such as possible financial gain through the relationships forged with other families through "speaking". He said that "one might as well stop working" when a previous-life family recognised a child because "people always picked wealthy families" for their "speaking" children.

69 We visited a family in Northern Israel/Galilee that had a "speaking" boy who claimed to remember a previous life in which he owned a caterpillar excavator. The family was very encouraging towards those memories, and constantly asked the boy what he remembered, even helping him to do so. Nonetheless, they stressed that while they had found out who the previous-life family were, they had not sought to contact them.

70 Most notably due to research by Ian Stevenson and Erlendur Haraldsson, descriptions of individual cases of "speaking" Druze children are far more known than the Druze as an ethnic-religious community. 


\section{"Speaking": Referring to an additional frame of reference}

In the context of transmigration, each life-circuit of the soul constitutes a frame of reference for a particular human being. Within this frame of reference, people belong to, or know, this human being; they have memories of him or her. As long as "speaking" does not cross the boundaries of that life-circuit, everything stays within this frame. In this case, references are univocally to this human being. If that human being says "I", "me", "mine" and so forth, he or she univocally refers to the person present; by saying "he" or "she", the others do the same or refer to someone who was present in this way.
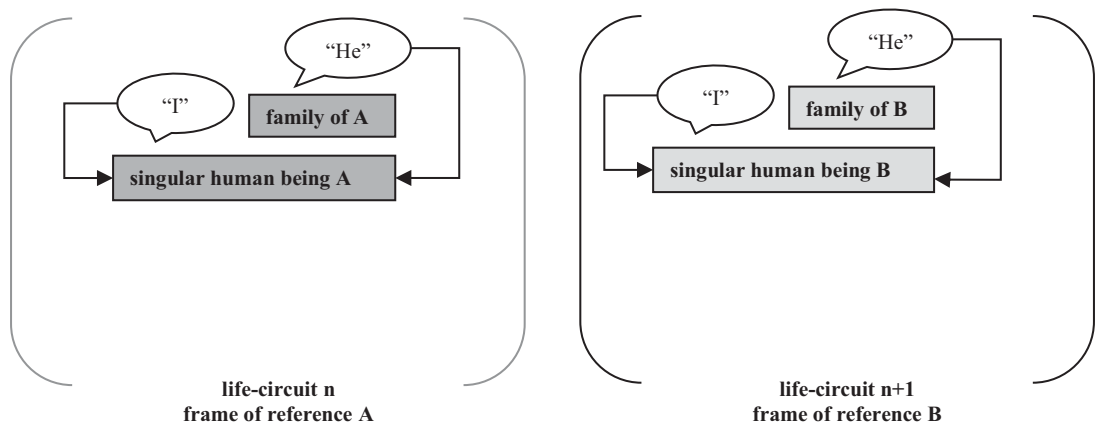

frame of reference $A$

life-circuit $n+1$
frame of reference $B$

Fig. 10: Absence of "speaking": Reference terms stay within one life-circuit and frame of reference. Graphics: Lorenz Nigst, 2020.

In the context of "speaking", the first-person references of the "speaking" individual cross the boundary into another frame of reference and become ambiguous because they refer not only to the human being present but also to another human being, life-circuit and frame of reference. Characteristically, "speaking" "switches on" an additional frame of reference; all statements of the "speaking" individual that contain a reference to the self encompass or span two ${ }^{71}$ frames of reference. In statements such as " $M y$ name is not Amjad, I am Ashraf", or "You are not my mother", the self-referent pronouns are characterised by this double reference to two individuals, one present and one who has died.

71 Or occasionally more than two. 


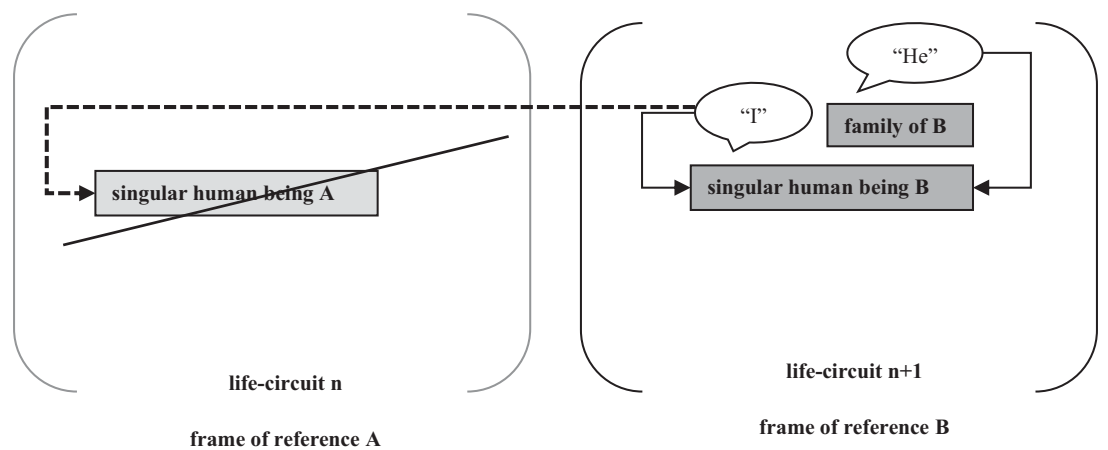

Fig. 11: Onset of "speaking": The "speaking" individual refers to another life-circuit and to himself or herself as a yet-to-be-identified individual. Graphics: Lorenz

Nigst, 2020.

It follows from the Druze idea of how transmigration works that the difference that exists between two human beings hides the identity of the soul involved in each of the two life-circuits. Most notably, if they end up associating two nameable human beings, cases of "speaking" make this abstract idea palpable. But when "speaking" reaches into another frame of reference, it (potentially) also knocks on the door of living others who have the lost family member the "speaking" individual claims to be. This way, it touches upon the memories and emotional bonds these living others have with their lost relative, which explains why the phenomenon is highly ambivalent. Likewise, it touches upon the feelings of the present-life family.

\section{Returning to a unique place: Making the relation of identity "real"}

It follows from the Druze assertion that the soul is always in a body that the relation of identity claimed by taqammus cannot be "real" except in the form of a relation of difference. This also shows in the concrete occurrences of "speaking", in which the "speaking" individual becomes associated with another deceased individual based on the idea that both are different manifestations of the same soul. One end of that relation (i.e. the person who has died) by definition is not there anymore. Under these circumstances, the association of two different human beings, with whom the soul is necessarily identified in real life, can become a sociological and recognised reality only through the family of the person who has died. The departed person occupied his or her singular place in that family and which survives his or her death. 


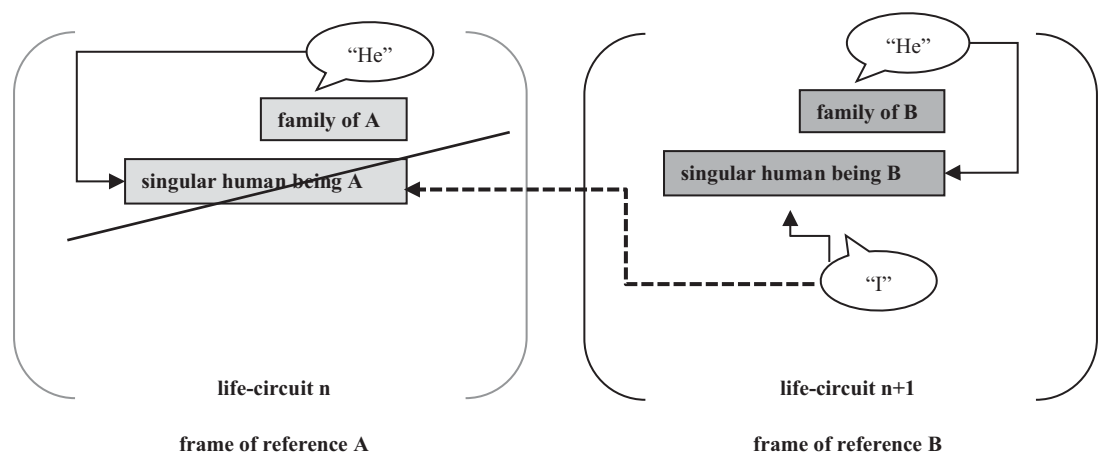

Fig. 12: "Speaking": The "speaking" individual refers to himself or herself as an identified individual whom others refer to as someone else. Graphics: Lorenz Nigst, 2020.

This singular and unique place is not a given but had to be bestowed upon the deceased individual. More specifically, it requires that as a child continues to be caught in a "singularisation process" ${ }^{72}$ Initiated long before birth (Boltanski 2013: 20), this process enables the "access, after birth, to a singular position in society" (Boltanski 2013: 49) and allows the human being in question to be identified individually "without any possibility of being confused with another" (Boltanski 2013: 28-29). At the bottom, this requires that the human being in question is not only human "in flesh" but is "taken up in a symbolic mode" and “in speech" (see Boltanski 2013: 37).

To put it differently, if in the cases of "speaking" the identity of the soul is claimed with respect to two particular human beings, and the only thing that links these two people is the "speaking" child's claim that both are manifestations of one identical soul, the need arises to reconstruct or establish the relation of difference. Logically, since one individual has passed away, the only way back into the "previous-life" frame of reference is through the singular place that the deceased individual left behind. The "speaking" individual has to be allowed to reoccupy that place, associating him or her with it. Only then can the claimed identity of the soul become "real" at this level. However, that requires that the singular place be opened and that the "speaking" child be "let in". Recognition or confirmation by the family (or individual family members) of the deceased individual appears to be the only way for this to happen.

72 On singularity, see Boltanski (2013: 29-49). 
Thus, when the previous life is "switched on" by "speaking", self-referent terms such as "I" cross the boundaries of the frames of reference that constitutes the current and the previous lives. Consequently, if the "I" which, according to Druze discourse, is trying to make itself heard through "speaking" shall be "real", it must be recognisable and recognised as a particular "he" or "she" who has passed away. ${ }^{73}$ This requires resituating the "speaking" individual within the frame of reference of the life of the person to which the "speaking" refers. Yet, because that individual is gone, this singular place and frame of reference can only have any "reality" and be "opened" through those who belonged to him or her, in whose fold singularity was bestowed upon him or her, who survived him or her and who have memories of him and her. No other force in the universe could ever hoist the "speaking" individual into that singular place.

This necessity of recognition by the previous-life family is significant because it corroborates that singularity, and singular places are not a given but have to be bestowed upon a human being. The phenomenon of "speaking" brings this fact out much more forcefully. ${ }^{74}$ The previous-life "I" can only be there in a unique place. The surviving relatives of the "speaking" "I" confirm his or her identity through accepting narratives that encompass things he or she owned, secrets only he or she knew, memories he or she verbalises, etc. Paraphrasing Anne Bennett, taqammus is about reconciling the past with the present (see Bennett 1999: 103), but this past can only be accessed and "real" through the presence of those who belonged to that past.

Logically, this form of recognition also requires that the family of the "speaking" child let it happen. That is, the claims made by the "speaking" child can become "real" only if people from both frames of reference accept that the

73 Beyond the scope of this chapter, we need to reflect more carefully upon "speaking" from the perspective of speech act theory. Uttered in the appropriate socioreligious context, "speaking", and the other forms of speech that respond to it, has consequences. They do something. Neither the claims made by the "speaking" child nor the recognition that may be granted are simple factual statements. Only after a more or less longwinded process can phrases like "A used to be B in his previous life" be understood as stating the facts.

74 The fact that only the previous-life family can bestow the recognition, without which the "speaking" child cannot "really" occupy the singular place of the deceased individual is corroborated by the reports about how "speaking" children gave "proof" that the were the deceased individual. This proof-giving always seems to involve family members of the deceased individual. This is significant given the "forensic" terminology involved. If "proof" as such was the only issue, this could be delivered by anyone, non-family-members included. 
pronouns and names with which they refer to the "speaking" child or deceased individual apply to more than one frame of reference at the same time. ${ }^{75}$ For this unique form of recognition to happen, the relations and emotional bonds that link individuals with the families to which they belong(ed) need to be reconciled with, subordinated to or used for the sake of the other relation and "spiritual reality" of the identity of the soul involved, which is at odds with the transient relations that link the individual with their families. ${ }^{76}$

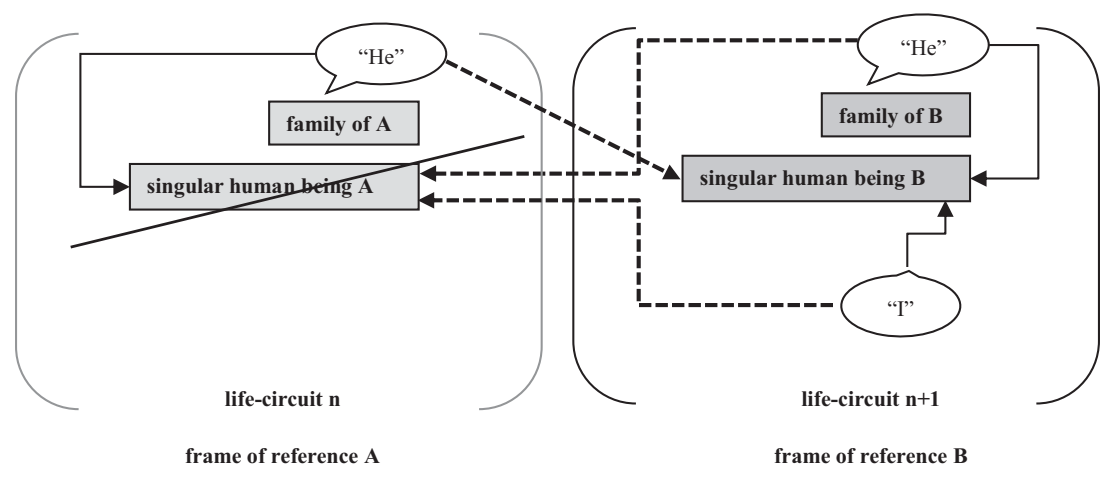

Fig. 13: Fully confirmed cases of "speaking": Both present-life and previous-life family also refer to their family members across the boundary separating the lifecircuits and the soul's successive sojourns ("past"/ "present") becomes concrete social relations and a shared space in which memories can surface. (If only one family reaches across the boundary, whatever the direction, "speaking" is not fully recognised.) Graphics: Lorenz Nigst, 2020.

If having episodic memories is a person-making characteristic, is having "real" episodic memories of a previous-life contingent upon having a recognised

75 It is remarkable how often people say things like: "This is me in $m y$ previous life"; "I know that $m y$ son was with other people before"; "In this moment, I knew that he is my son".

76 Significantly in this context, Druze Shaykh Bahjat Ghayth distinguishes between a person's "spiritual life" (hayāt rūhāniyye) and "everyday life": "il-insān ilo maslakayn fi hayāto ilo hayāh yawmiyye muta"arjih a mutaqallibe w-ilu hayāh rühiyye kawniyye azaliyye thābite". See https://www.youtube.com/watch?v=2tEy3mjXD8s (accessed 17 May 2018). 
singular place? Is having recognised episodic memories a form of belonging? ${ }^{77}$ Rather than episodic memories "proving" personal identity, does having a personal identity "prove" the episodic memory and give it "reality"? Is the "reality" of the previous memories, and thus the "return", time socially constituted?

\section{Proving the connections: "Returning" to the proof}

The singular place that the deceased individual occupied is not available all that easily, but retaking it requires proof. The centrality of the act of "giving proof" (ithbātāt, sg. ithbät; adilla, sg. dalìl) within the retellings of individual cases of "speaking" seems to be all but coincidental, but it reflects how counterintuitive the "speaking" child's claim to be another particular person actually is. The feeling of being in the wrong place is considered indicative of the truth of the "speaking" child's claim. Decisive forms of proof are different. ${ }^{78}$ These require

77 Apparently only surviving relatives of the deceased person that the "speaking" individual claims to be can grant the recognition necessary for turning their claims into something "real". This bears upon the perceived authenticity of a particular case. Our interview partners occasionally mentioned that some people claimed to have the memories of famous historical figures such as Druze Sultan al-Atrash. Unlike cases where previous-life family members recognise the "speaking" child, the authenticity of such cases tends towards zero. Not least, this is because the "speaking" individual simply cannot reoccupy that singular place by his or her own will, and no family members that could grant the recognition are alive. These different categories of claims are worlds apart. One interview partner from Lebanon told us how her previous-life mother was happy to have found her again. At the same time, she claimed to also have memories leading back to chronologically much earlier times when the French were present in the region, that is, when her soul had been in yet another body. It is hard to describe the different "flavour" of these two stories, one of which cannot involve a vis-à-vis whereas the other is engrossed in the complex emotional situation where a previous-life mother maintains continuing bonds with the daughter she had lost and has to reconcile - and combines - her love for that lost daughter with her love for the other person as which her daughter now manifests.

78 For the thematic complex of "proof", see French (2016: 90-91), Haraldsson and AbuIzzeddin (2002: 372-375), and Nigst (2017: 68-70). Significantly, proof considered decisive mostly consists in knowledge of things or events that occurred between the individual whom the "speaking" child claims to be and his or her relatives, which no one else "could possibly know". As one interview partner stated, the "speaking" child might know the "secrets of the family" (see Nigst 2017: 69). Veritable topoi occur frequently in retellings of such cases, such as knowledge of where valuable items, money, or weapons are buried; of sentences said in private, or of stillborn children. But many other things occur. One interview partner recalled the suffering of his previous-life 
"returning" to highly specific memories and items. Despite the centrality of giving proof in the narratives about the recognition process, much more research needs to be dedicated to what actually happens here. Which emotional, social, political and other factors play a role? ${ }^{79}$ In any case, many elements in the Druze discourse stress that no cynicism is involved. Although sometimes parents are suspected of "making their children speak" (națaqa), people consistently describe the experience that "speaking" happens beyond anyone's control and simply washes over people. In a sense, the fact that "speaking" is unwanted "proves" its truth (see Nigst 2019a). Likewise, emphasising their utter lack of cynicism and genuine feeling of being overwhelmed emotionally by cases of "speaking" that affected them, several interview partners in Israel showed us the goose bumps on their arms. Emerging even many years after a "speaking" child first activated that additional frame of reference in which one found the lost relative again, they were presented as the best proof of sincerity.

\section{Living the connections: Living the "return"}

It is plausible that the connections between two life-circuits made palpable through "speaking" engender both difficulties and unique possibilities. In a way, the possibilities are the difficulties and the difficulties are the possibilities. The conceivable instances of relating across the boundary between two frames of reference outlined in Fig. 13 simultaneously represent a field of possible consolation and union and of fears, anxieties, worries, contradictions and possible conflict. This form of relating across two frames of reference is "nice, and not so nice at the same time" (helu mush helu), ${ }^{80}$ as one interview partner put it. By definition, "speaking" begins with the unexpected and "untimely" loss of a family member with whom one maintains continuing bonds. Thus, recognising the "speaking" of a child may transform or expand these bonds into new real-life relationships, entailing the perception that the relative lost to death has "returned" (his or her soul has returned in different form). One

mother when he had to give himself injections for a chronic disease. Remarkably, even in cases where the recognition of the "previous-life" family is lacking, these topoi occur. One interview partner told us how he dug up a box which he had buried in the garden of his previous-life house while his previous-life family, who he did not want to meet, was not at home. In such cases, the unique previous-life place is claimed to have been identified, but there is no recognition "by speech".

79 For these questions, see also Bennett (2006: 94-95).

80 This closely corresponds to Anne Bennett's accurate characterisation of taqammus as "bittersweet" (see Bennett 1999: 108). 
interview partner in Lebanon told us that her previous-life mother both kissed and touched the photographs of her departed daughter and kissed and hugged her, which she found less and less to her liking (see Nigst 2019a).

Going beyond the scope of this chapter, we need much more research into how people engage with this double presence of a human being and how they reconcile their grief and the continuing bonds they maintain with their lost family member with the new bodily presence of the "speaking" individual. Besides the sociological reality of the singular place, there is the emotional reality and the question of how individual family members manage to disconnect the personal identity from the body or can perceive their lost relative behind the new body. Are there people whose continuing bonds and feelings lead to not wanting a "speaking" child to "retake" the singular place of their departed relative and who cannot or will not accept that the new relationship eclipses the reality of the lost life ${ }^{81}$ Furthermore, if the previous-life family recognises the "speaking" individual, the ensuing fact of occupying two singular places and having two belongings has potential not only for intimacy and joy but also for all sorts of difficulties. It is ambivalent in many respects.

Despite the positive descriptions of cases of "speaking" and reunions that are happy and lasting, many people experience these ambivalent, or even negative, consequences, which are eminently real by virtue of the social forces involved, since these forces allow the previous-life place to be reoccupied. ${ }^{82}$ To begin with, Druze often mention in interviews that while having vague memories that have not yet led to a previous-life family might be difficult enough, actually reoccupying an additional singular place requires even higher levels of coping with the inner conflict and the contradictions (tanäqud) of (objectively) competing familial belongings (see Bennett 1999: 103).

The affected individual threatens to "become like two personalities" (șār "indak izdiwājiyye bi-sh-shakhșiyye; bișīr mithl shakhșiyyatayn) ${ }^{83}$ and "to get lost" (bid̄ì il-walad; bi ìsh bi-ḍ-ḍyā) in a "gigantic maze" (matāha țawìla 'arì $(a) .{ }^{84}$ They insisted that it was "not good to grow up like that" (harām

81 For an example in the Lebanese media, see Nigst (2017: 74).

82 The statements documented in our research project thus largely corroborate Anne Bennett's observation that most of her interview partners emphasised the "less pleasant aspects of the experience" (Bennett 1999: 108).

83 See also https://www.youtube.com/watch?v=XGN-TgQ-0iM (accessed 9 June 2017); $\min 13: 55 \mathrm{ff}$.

84 To quote an expression by Druze Shaykh Sāmī Abī l-Munā; see https://www.youtube. com/watch?v=XGN-TgQ-0iM (accessed 6 June 2017). 
tikbar hèk), wanting to be "here" and "there" at the same time, and they often underlined the potential psychological damage (khatiin bi-nafsiyyit il-walad) resulting from such a situation. Considering that one of these two personal identities is the "outdated" previous life, our interview partners occasionally emphasised that the previous-life family was responsible for ensuring that a previous life-circuit did not encroach on the present life of their child. They explicitly discouraged resituating the "speaking" child an additional, and objectively competing, frame of reference. Many of them seemed to believe that "having been" someone else with another family did not have the same force as "being" someone now; they emphasised that the present and the previous life were different. They expressed this thought in a variety of ways, mostly referring to someone's "old person" (shakhșo al-qadim) and "new person" (shakhșol-jdìd). They repeatedly stated that someone lived with a "new mind" (bi-'aqlo l-jdìd) or a "new brain" (bi-dimägho l-jdìd) or "thinks in a new way" (bifakkir bi-tarìqa jdida') (see also Nigst 2019a). In their view, not letting the "outdated" previouslife circuit encroach upon the present life was tantamount to "protecting" the life of the child and ensuring an "undamaged" (salim) upbringing, not to mention that the death was often violent. The present-life family should "protect" the life of their child (härisin hayäto) and shield him or her from being dragged into an alternative and competing form of belonging that has had its time (see Nigst 2017: 78).

Recognition of a "speaking" child through the previous-life family forces a form of proximity on both the families involved and the "speaking" individual, which may be perceived as pleasant at some times (and sought out of strategic reasons), but not at others. "Like any familial relationship", the relationship based upon the recognition of a "speaking" child is "alternately a source of both anxiety and delight" (Bennett 1999: 92). When the previous-life family recognises the "speaking" child, the present-life family may perceive that their child is pulled into another familial orbit and that to an extent they are losing him or her. Since "speaking" leads to the double presence of the soul in the form of two of the transient manifestations that the worldview claims, each manifestation is a loved human being that belongs to one particular family and not another. It is plausible that some families prefer that this unique belonging stays unique. As one interview partner stated, "[a] family always loves its child, and they want it to belong only to them, and not to two families". Present-life mothers are said to be especially distressed by the perception that their child, to an extent, has become associated with others (däiman il-imm bithibb tifla) 
(see Dwairy 2006: 35) ${ }^{85}$ Even in cases where the parents encouraged their child to "speak" and identify with the previous-life family, the present-life family may have the impression that the previous-life family is "stealing" the child (see Dwairy 2006: 44). Notwithstanding such negative feelings and fears, it is crucial to underline that cases of "speaking" potentially allow relations between families to be established that otherwise could never come about, or would certainly be different. It would be surprising if belief in the "speaking" could not accommodate the interest in forging such relations.

In any case, it is remarkable that Druze themselves clearly insinuate that some parents were paving the way for their children to "speak" ${ }^{86}$ Not least, this leads to the situation that sometimes more than one "speaking" child claims to be the same departed person, which has been criticised by members of the Druze religious establishment. ${ }^{87}$ At times, people seem to claim strategically that their "speaking" child is the reincarnation of an individual who had accumulated substantial socioreligious capital or belonged to an important family. ${ }^{88}$

\section{Suppressing connections: "Silencing" the "speaking" child and stalling the "return"}

Although some people do not think that concrete cases of "speaking" are something to be too worried or alarmed about (rawāq), it makes sense that, faced with the myriad difficulties that "speaking" may entail, others attempt to "silence" (sakkata) their "speaking" children and "prevent them from speaking" (mana'a min al-kalām). ${ }^{89}$ They opt for supressing the "speech" which is switching on the competing frame of reference. Since for Druze, "speaking" corresponds to the verbalisation of memories, "silencing" equals "making the

85 See, for example, http://www.aljoumhouria.com/pages/view/19492/2799 (accessed 19 May 2017).

86 See, for example, https://www.youtube.com/watch?v=XGN-TgQ-0iM (accessed 15 June 2018), min 49:00 ff. ("man yufsih al-majāl amām at-tifl li-yatakallam"). For the context of this statement, see also Nigst (2019a).

87 See, for example, www.annahar.com/article/395204 (accessed 29 November 2016). See also French (2016: 92).

88 The important Druze religious figure Muhammad Abū Hilāl (ash-Shaykh al-Fāḍil) (d. $1640 \mathrm{CE}$ ) rejected the claim spread in his honour that he was the reincarnation of the famous Druze Dāî 'Ammār. To all appearances, he considered this claim a temptation (Schmucker 2000: 162).

89 See Bennett (1999: 88); Dwairy (2006: 40); see also Lațif (2014: 267). 
child forget" (ansā) $\cdot{ }^{90}$ Our interview partners frequently mentioned that many people tried to "deafen" (bitarrsho) their children with regard to the voices of the past, although they said that this did not always work. ${ }^{91}$ Children who were unsuccesfully encouraged to forget became "difficult" (mashkalji), more and more angry and vengeful (nāqim) because their present-life parents were reluctant to find out about their previous-life personal identity and unique place. As one of our interview partners suggested, the decision to "silence" a "speaking" child is often also motivated by the wish not to "have a child who is not a child at the same time" (tifl huwa mush tifl). According to several of our interview partners, forgetting was necessary because people "cannot not live two lives

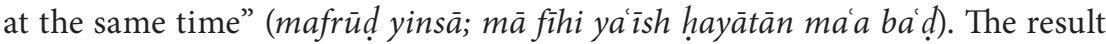
would be confusion, and many families do not want the feeling of being "torn between two families" (Dwairy 2006: 40).

\section{Acquiescing to the connections: Accepting "return" as a need of the "speaking" child}

"Silencing" children is not the only way of responding to the pull of another singular position. Closely mirroring the poetic developments mentioned above, according to which the soul remains emotionally attached to its previous life-circuit for some time and cannot "let go" instantly, our interview partners suggested that even in cases where the previous-life family recognised the "speaking" child, the pull of the previous life was not necessarily constant because the memories of that life, like other memories, naturally faded away with time. Growing more familiar with his or her present life (biṣir yit'aqlam $i j b \bar{a} r \bar{i}$ ) and developing emotional ties with the new family (yikūn yit'alla' b-ayle $j d \bar{i} d e$ ), the child's intense desire to return to the previous life may lessen or fade away entirely. As a result, "speaking" children may emerge in another familial context but may disappear from it again (see Nigst 2017: 76-78, 2019a).

In this context, identifying "as" and "with" someone do not necessarily coincide. For the personal identity of the "speaking" individual, the more important element seems to be identifying with someone, positively or negatively. If a "speaking" child grows up, he or she may still identify as the deceased individual, but less and less identify with him or her. Even if one already identifies as that person, fear of meeting the previous-life family could be motivated by the difficulty of identifying with one's previous-life self. One of our interview

90 The motives for such "silencing" are not necessarily clear, however. See Nigst (2019a).

91 On "silencing", see Nigst (2017: 76-78) and Nigst (2019a). 
partners told us that he was not a good person in his previous life and avoided establishing contact with the previous-life family. This meant that he could not be recognised by that family, leaving him in limbo. If "speaking" is tantamount to entering an additional frame of reference, belief in "speaking" is tantamount to taking that form of relating seriously and let it guide one's actions, whether acknowledging a "speaking" child as one's lost relative, seeking to suppress the "speaking" or accepting that such double feelings of belonging are normal for a soul which has lost its previous place and may go away again.

\section{Meaningful "returns": Retributive and reparative justice}

For most Druze, transmigration is not a random or meaningless "change of shirts". ${ }^{2}$ It is divine justice at work. By definition, this idea operates at a high level of abstraction and generalisation - silently and in an additive or retributive sense, divine justice materialises with regard to each individual soul. While situated human beings can never perceive the full itinerary of a soul, "speaking" highlights a smaller section of this itinerary through making accessible two concrete life-circuits. As a result, "speaking", and narratives about it, can fulfil purposes enmeshed and articulated in a concrete social situation involving particular human beings. It can make sense in a way the abstract notion of divine justice cannot.

If the idea that divine justice materialises in an additive way redefines inequalities and suggests that things happen just the way they had to happen, "speaking" creates more concrete opportunities for making transmigration meaningful. Narratives about individual cases of "speaking", often somewhat legendary ones, may communicate a moral lesson (see Rivoal 2000: 384), inculcate notions of honour by bringing to light blameworthy or dishonourable behaviour or "use the conception of a migrating soul in order to construct edifying narratives that provide an ideal picture of society" (Rivoal 2000: 382383). In some Druze accounts, "speaking" ends conflicts between families because the soul cuts across the boundaries between them, rendering questions of "us" and "them" absurd.

Druze also narrate incidences of "speaking" that solved cases of murder or in which the murder victim "returned" to take revenge (see Nigst 2019b). These narratives of revenge for the most unexpected and violent forms of death generally involved in cases of "speaking" (see Bennett 2006: 90-92); this revenge

92 See also Rivoal (2000: 384). 
corresponds to an effort at (re-)establishing justice. This form of justice is retributive.

Murder constitutes injustice par excellence. Nonetheless, other forms of unexpected death also feel unjust as under different circumstances the deceased individual could still be alive. Everday language highlights this perception of injustice clearly; people often state that a death "just was not fair". ${ }^{93}$ If someone lost to unnatural, violent,or unexpected death "returns" in the forms of a "speaking" child, this not only enables happy reunions with the previouslife family, as Druze often point out.

More specifically, in these cases the injustice that someone did not live the life he or she could have lived is perceived to be set right and "repaired". A Syrian interview partner illustrated how this reparative character of "speaking" was recognised by the previous-life family: "He continues with his life as if he were still alive" (see Nigst 2017: 70). Manifestly, this reparative function is also at work where the "return" serves as retributive. Druze discourse looks at the difficulty and pain of having been ripped out of life unexpectedly from the perspective of the soul, which has agency. People simply respond to the soul's needs or try to avert the difficulties by turning "speech" into silence. It seems plausible that through its reparative and retributive functions, "speaking" is a way of bringing some peace to those suffering from the sudden loss of a relative or to communities that cannot find peace due to an unpunished murder.

\section{Conclusion}

The perception that the successive and transient life-circuits of an individual soul are "connected" is present in Druze communities and discourse at different levels. On the one hand, the transient presence of the soul is considered as functioning within the working of divine justice. In this case, transient manifestations and the connections between them are imagined as making sense in the light of a divine regard. On the other hand, the perception that the soul in each of its life-circuits manifests as a distinct human being who not only is a member of groups but also occupies a unique place in the world leads to a different set of problems that cannot be reduced to the workings of divine

93 This clearly contrasts with passing away as an old person whose death was to be expected and who ideally should have taken ascetically minded steps away from the world and acknowledged the transient character of all the entanglements that ("falsely") seem to matter (see Oppenheimer 1980: 627). 
justice. Most notably, it raises the question of who the "dead" were and what they share with the (future) "living".

Owing to the lack of knowledge regarding the precise whereabouts of the soul's next or previous sojourns, Druze discourse focuses on the social identity of the soul's transient manifestations and looks at aspects of this identity which are replaceable or alike (confession, gender). Whoever the Druze soul was, or will be, it will be a "male Druze" or a "female Druze" again. This is what a Druze shares with their "dead" and "future" community members. This makes it possible to glimpse the eternal reality of the Druze souls hidden behind the transient bodily reality of the human being. This eternal reality constitutes a different form of existence and cohesion of the Druze community that does not consist of social and particularised individuals (see Rivoal 2000: 382) whose body is left behind on death.

In contrast, "speaking" brings connections between the transient manifestations to the surface as a link between two human beings with a name and a concrete familial belonging. Apart from often legendary Druze narratives about "speaking" that teach a certain moral lesson, in cases in which people are emotionally invested, "speaking" allows the "return" of someone lost to death and "repairs" the wounds caused by death that came way too soon. Most individuals referred to in cases of "speaking" died unexpectedly or violently - the perception that a human being is irreplaceable is probably never greater than when that person dies suddenly.

Recognised "speaking" implies a variety of things: that the memories voiced through "speaking" individuals are heard and the voice legitimate; he or she really belongs and the lost person lingers on in a more palpable way; a central element of the belief system which may not be relatable in any other way is corroborated; the continuity of the Druze collective and its boundaries is beyond doubt. "Speaking" also implies that the Druze idea that the identical always hides behind and manifests as the different needs to be worked out in real life. This requires coping with the weight of the particular human beings brought in relation through "speaking" who are the concrete living and dead of someone; someone's fathers, mothers, brothers, sisters, sons or daughters who cannot be put aside and relativised as easily as the transient manifestation of a soul for the sake of the identity claimed by the abstract assertion.

While real-life relationships established through "speaking" may be fulfilling and comforting, the very same reality is full of tensions and contradictions that seem to reinforce the decision of many not to go beyond the confinements of one life-circuit. The choices, difficulties and fears involved in making this decision are a reminder that it is not easy for a human being to take or disappear from 
his or her place. Not least, it may be asked if the focus on "speaking" may eclipse more silent, but no less real, forms of continuing bonds. More simple-hearted or exaggerated stories of "speaking", or all-too-obvious attempts to forge relations, seem almost frivolous in comparison to the tremendous exercise of coping with the loss of a beloved person, even if, unlike in most "speaking" cases, this loss was not tragically unexpected.

\section{Literature}

\section{Manuscript sources}

Bibliothèque nationale de France, Arabe 1429.

Bibliothèque nationale de France, Arabe 1436.

\section{Secondary literature}

Armanet, Eléonore 2003. "Le Livre druze, entre corps et narration," in: Studies in Religion / Sciences Religieuses 32/4, pp. 395-408.

Armanet, Eléonore 2011. Le ferment et la grâce: Une ethnographie du sacré chez les Druzes d'Israël. Toulouse: Universitaires du Mirail.

al-Bāshā, Muhammad Khalīl 2009. At-Taqammus wa-asrār al-hayāt wa-l-mawt fì daw' an-nașs wa-l-'ilm wa-l-ikhtibār. Aț-țab a ath-thāniya. Bayrūt: Nawfal.

Bennett, Anne 1999. Reincarnation, Marriage, and Memory: Negotiating Sectarian Identity among the Druze of Syria. Dissertation, University of Arizona, USA.

Bennett, Anne 2006. "Reincarnation, Sect Unity and Identity among the Druze," in: Ethnology 45 (2), pp. 87-104.

Boltanski, Luc 2013. The Foetal Condition. A Sociology of Engendering and Abortion. Cambridge and Malden: Polity Press.

Bouveresse, Jacques 2007. Peut-on ne pas croire? Sur la vérité, la croyance \& la foi. Marseille: Agone.

Bradbury, Ray 2013. Fahrenheit 451. New York: Simon \& Schuster.

Carbó, Antoni Gonzalo 2004. "La teología doblemente negativa de Hamîd alDîn al-Kirmânî y Moisés de León." Conferencia pronunciada el 12 de febrero de 2004 en el Aula de Grados de la Facultad de Filosofía de la Universidad de Sevilla, dentro del ciclo titulado «Estudio comparado de las Tradiciones Espirituales: La Temporalidad Sagrada» («Seminario Permanente de Hermenéutica Comparada»), Sevilla, enero-marzo de 2004. 
de Smet, Daniel 2007. Les Épîtres sacrées des Druzes: Rasā’il al-Hikma, vols. 1 et 2, Introduction, édition critique et traduction annotéedes traités attribués à Hamza b. 'Alì et Ismā'ì at-Tamìmì. Leuven, Peeters.

Dwairy, Marwan 2006. “The Psychological Function of Reincarnation among Druze in Israel," in: Culture, Medicine and Psychiatry 30, pp. 29-53.

Firro, Kais 2011. "The Druze Faith: Origin, Development and Interpretation," in: Arabica 58, pp. 76-99.

French, Christopher C. 2016. "Reincarnation Claims," in: D. Groome and R. Roberts (eds.): Parapsychology: The Science of Unusual Experience. London: Psychology Press, pp. 82-95.

Haraldsson, Erlendur and Majd Abu-Izzeddin 2002. "Development of Certainty About the Correct Deceased Person in a Case of the Reincarnation Type in Lebanon: The Case of Nazih Al-Danaf," in: Journal of Scientific Exploration 16 (3), pp. 363-380.

Kastrinou, Maria 2016. Power, Sect and State in Syria: The Politics of Marriage and Identity amongst the Druze. London: IB Tauris and Co Ltd.

Laṭîf, Ilyās Laṭîf 2014. At-Taqammuṣ wa-tadhakkur al-ḥayāt as-sābiqa: intiqāl al-rūh am adh-dhākira? S.l.

Naṣr, Mursil 2004. Máālim al-ḥalāl wa-l-harām 'ind al-Muwahhidìn «ad-Durūz». S.l.

Nigst, Lorenz 2017. "Being One and Two and Druze: Problems of Belonging in the Remembrance of Previous Lives," in: International Forum on AudioVisual Research / Jahrbuch des Phonogrammarchivs (8), pp. 56-81.

Nigst, Lorenz 2019a. "Entering a Gigantic Maze: The Ambivalent Presence of Previous-Life Memories in Druze Discourse," Social Compass 66(2), pp. 273-288.

Nigst, Lorenz 2019b. "Druze Reincarnation through Fiction: Anīs Yahyā’s novel Jasad kāna lì as a Source for Literary Anthropology," Journal of Arabic and Islamic Studies 19, pp. 15-34.

Oppenheimer, Jonathan W. S. 1980. “'We Are Born in Each Others' Houses.' Communal and Patrilineal Ideologies in Druze Village Religion and Social Structure," in: American Ethnologist 7(4), pp. 621-636.

Pascal, Blaise 1683. Pensées de M. Pascal sur la religion et sur quelques autres sujets, Qui ont estés trouvées après sa mort parmy ses papiers. Edition nouvelle, Augmentée de beaucoup de Pensées, de la Vie du méme Autheur, \& de quelques Dissertations, marquées dans la page suivante. Amsterdam: Abraham Wolfgang. 
Prager, Leila 2016. "The Miracle of Rebirth: Stigmata, Transmigration, and the Remembrance of Former Lives in Alawi Religion," in: S. Kurz, C. Preckel, and S. Reichmuth (eds.). Muslim Bodies, Body, Sexuality and Medicine in Muslim Societies. Münster and Berlin: LIT, pp. 281-310.

Quante, Michael 2002. Personales Leben und menschlicher Tod. Personale Identität als Prinzip der biomedizinischen Ethik. Frankfurt am Main: Suhrkamp.

Rivoal, Isabelle 2000. Les maîtres du secret: Ordre mondain et ordre religieux dans la communauté druze en Israël. Paris: Éditions de l'École des Hautes Études en Sciences Sociales.

Rivoal, Isabelle 2016a. Druzes de la montagne libanaise. Monographie originale présentée en vue de l'Habilitation à Diriger des Recherches. Vol. 2 / 3. Paris: Université Paris Ouest Nanterre la Défense.

Rivoal, Isabelle 2016b. Études et recherches. Sélection de travaux et articles présentés en vue de l'Habilitation à Diriger des Recherches. Vol. 3/3. Paris: Universtié Paris Nanterre la Défense.

Sattig, Thomas 2017. "The Sense and Reality of Personal Identity," in: Erkenntnis (online September 2017), pp. 1-18.

Schmucker, Werner 2000. "Muhammad Abū Hilāl ('ash-Shaykkh al-Fādil'), ein Drusenheiliger," in: Hallesche Beiträge zur Orientwissenschaft 29 (2000), pp. 145-169.

Seybold, Christian 1902. Die Drusenschrift: Kitāb Alnoqat Waldawāir. Das Buch der Punkte und Kreise. Leipzig: Kirchhain N.-L.

Silvestre de Sacy, Antoine-Isaac 1838. Exposé de la religion des Druze tiré des livres religieux de cette secte, et précédé d'une introduction de la vie du Khalife Hakem-Biamr-Allah. Vol. 1-2. Paris: Imprimerie royale.

Stevenson, Ian 2001. Children Who Remember Previous Lives: A Question of Reincarnation. Revised edition. Jefferson and London: McFarland \& Company

Stevenson, Ian and Erlendur Haraldsson 2003. "The Similarity of Features of Reincarnation Type Cases over Many Years: A Third Study," in: Journal of Scientific Exploration 17 (2), pp. 283-289.

Swayd, Samy 2006. Historical Dictionary of the Druzes. Landham, Toronto, and Oxford: Scarecrow Press (Historical Dictionaries of Peoples and Cultures, No. 3).

Talī', Amīn 2001. At-Taqammuṣ. Aț-țab'a ath-thāniya. Buqāàta: Máriḍ ash-shūf ad-dā'im li-l-kitāb. 
Tucker, Spencer C. and Priscilla Roberts (eds.) 2008. The Encyclopedia of the Arab-Israeli Conflict: A Political, Social, and Military History. Vol. 1-4. Santa Barbara: ABC-Clio.

Yahỵā, Anīs 2002. Jasad kāna lī. Bayrūt: Dār al-Farābī.

\section{Online sources}

Carbó, Antoni Gonzalo 2004. "La teología doblemente negativa de Hamîd alDîn al-Kirmânî y Moisés de León." Conferencia pronunciada el 12 de febrero de 2004 en el Aula de Grados de la Facultad de Filosofía de la Universidad de Sevilla, dentro del ciclo titulado «Estudio comparado de las Tradiciones Espirituales: La Temporalidad Sagrada» («Seminario Permanente de Hermenéutica Comparada»), Sevilla, enero-marzo de 2004; accessible at: https://ibnarabisociety.es/index. php?pagina $=35 \&$ lang $=($ accessed 11 June 2018) .

https://www.youtube.com/watch?v=J_lp647E19A (accessed 17 April 2018). https://www.youtube.com/watch?v=yKaVQ15AljA (accessed 15 May 2018). https://www.youtube.com/watch?v=r2DMK0YSfj8 (accessed 15 May 2018). https://www.youtube.com/watch?v=0_v2Pb9jopo (accessed 19 May 2017). https://www.youtube.com/watch?v=Kp_kNBIyykc (accessed 09 May 2018). https://www.youtube.com/watch?v=2tEy3mjXD8s (accessed 17 May 2018). https://www.youtube.com/watch?v=uN4levEgl0Y (accessed 01 June 2018). https://www.youtube.com/watch?v=fr5T4TTBr6w (accessed 01 June 2018). https://www.youtube.com/watch?v=5TnlGOodylA (accessed 05 August 2017). https://www.youtube.com/watch?v=euEbPA-3iaA (accessed 07 May 2017). www.annahar.com/article/395204 (accessed 29 November 2016). https://www.youtube.com/watch?v=XGN-TgQ-0iM (accessed 07 April 2017). http://www.aljoumhouria.com/pages/view/19492/2799 (accessed 19 May 2017). 


\section{"For us, death does not exist and the taqammus keeps us close": Reincarnation and Subjectivities in the World of the Druze}

\section{Introduction}

Established for nearly a thousand years across Syria, Lebanon, Israel and Jordan, the Druze community has preserved its uniqueness despite the global societies in which it is now embedded. How has the community been able to construct and perpetuate its marked inwardness in an era of cultural hybridisation and in the face of the current persecution of minorities across the Middle East? This question originally triggered my interest in Druze belief in the transmigration of souls (taqammus al-arwāh, lit. "re-enwrapment of souls"), not a mere doctrine but a social institution embodied in discourse and practices. As a "secret" (sirr) kept from the non-Druze world, taqammus implies a belief in the continual re-emergence of all life, connecting the living with the dead. Viewed as part of the very foundations of collective order and its continued existence, taqammus relativizes the importance of lineage and blood paradigm.

In a community so focused on its own interconnected reproduction, are members of the group merely "acted upon" (Mittermaier 2012) and more or less interchangeable? Conversely, how does the Druze community mould subjects despite its prescription of identical reproduction? Above all, what is a subject in the world of the Druze? While it may be true that members of the group are not interchangeable, what are the logics that ensure their individuation?

In this chapter, I present the taqammus primarily as I witnessed it - or attempted to witness it - during field research conducted in Arabic in Upper Galilee (Israel) over a period of nearly three years. I say attempted because the secret thread of taqammus remained shielded from any discourse I might have called upon. Because of this, I was careful to focus on the spoken discourse surrounding the theme within the intersubjective realm of households, but also the silences and, specifically, the many forms of conscious silence - or what I term "no-telling" (msattara) - surrounding taqammuṣ. Throughout this "wandering" ethnography, I was able to collect abundant material, although

1 Aix-Marseille Université, CNRS, IDEMEC, Aix-en-Provence, France. 
I did little with it initially, preferring instead to focus on anthropological topics less affected by the unsaid and the unspoken. Using the theoretical tools of phenomenological and semantic anthropology, I discovered a matricentric and egalitarian society little marked by death: fascinated as I was by its ambition of endogenous reproduction, I found, through participant observation, that the Druze community is shaped by dynamics of envelopment and incorporation: intercorporeality emerges as the true source of social relationships and sociality (Plancke 2014: 13).

To complete my argument here, I draw on ethnographic material collected in Lebanon, a country I have visited every year for the past five years - specifically, the mountainous region of Shūf and Beirut. My data are drawn from interviews conducted with children and adults living their lives as reincarnated beings and with their relatives, but also from broader conversations with both religious and secular members of the Druze community. ${ }^{2}$ My analysis is rooted in the meaningful relationships I built with the Druze community as I went from being considered a foreign guest to a relative and later on to an adoptive granddaughter. I claim here a responsible epistemology, literally an epistemology in response, loyal to my adoption by the Druze.

Before getting to the heart of the matter, I begin with a general introduction to the Druze community. I discuss various methodological and epistemological questions: my premise is that since the Druze belief in taqammus is confined to a strict intersubjectivity, ethnographic curiosity appears doomed to failure. Under these conditions, to what extent is it possible to conduct an ethnographic study of taqammus among the Druze? What mode of subjectivity is an anthropologist invited to adopt?

I then examine taqammus through the powerful and verbose rhetoric to which it gives rise, both in Lebanon and Israel: I show that this rhetoric shapes how the Druze represent themselves to themselves and to others, connected as they are by a community of shared affects. I then set out to identify some of the impact of this discourse on the social fabric of individuals, paying particular attention to the care of young children and the perception of early childhood. What does it mean to form a family with a newborn - a being viewed immediately as complex, hyper-socialised and inhabited by the thoughts and gestures of an adult (Gupta 2002: 33)?

I end by addressing the question of the "Druze subject". Specifically, while it may produce a community of immortals, to what extent can the Druze

2 All translations of interviews are my own. 
community be said to shape subjects? I show that the world of the Druze invites us to rethink the notions of subjectivity and ethics in their Eurocentric dimensions.

\section{A brief presentation of the Druze community}

With an official count of 1.5 million members worldwide, the Druze community has been rooted in the Middle East for nearly a thousand years. Territorially fragmented across the area, the community is divided between Syria, Lebanon, Jordan and Israel, where members have settled in villages in the north of the country.

Though little known among non-Druze and in the literature, small established communities can also be found in the Maghreb, Turkey, Yemen, India and Pakistan (Khuri 2004: 22-23). Other groups that emigrated in the nineteenth and twentieth centuries can still be found in Australia, the Philippines, the United States and Canada (Haddad and Smith 1993: 23-48), South and Central America (Roussel 2004: 322), West Africa and the Persian Gulf.

Uniquely, the Druze community is much concerned with preserving its intimacy: one is born Druze, conversion is shunned, and the Druze abide by the rule of "no-telling" about their sacred text, the Book of Wisdom (Kitāb alhikma), sometimes referred to as Epistles of Wisdom (Rasä'il al-hikma). The Druze practise denominational endogamy. However, one of the effects of this deep attachment to strong intracommunity bonds is the lack of any desire for a unitarist political formation. While it is fundamental, the integration - the rootedness - of the community in space needs to be qualified by the Druze belief in the transmigration of souls (taqammus): the soul (rūh) and religion (din) are construed as the real ties of the individual and the community.

As a trans-state and polycentric whole, the community maintains itself in part through its religious hierarchy, at the head of which is Shaykh al-Aql, responsible for the social and political guidance of the entire Druze community, and Shaykh ar-Rūh, whose focus is the religious affairs of the community at a national level.

3 A similar presentation of the Druze community has appeared in a previously published journal article in 2018: Armanet, Eléonore. 2018. 'Allah has spoken to us: we must keep silent.' In the folds of secrecy, the Holy Book of the Druze. In: Religion, Taylor \& Francis (Routledge), 48 (2), pp. 183-197. DOI: ff10.1080/0048721X.2017.1386370ff. ffhal-01789462. 
Historically, the Druze settled in Fatimid Egypt in the eleventh century in response to religious preaching initiated in Cairo. Developed at the end of Caliph al-Hākim bi-amr Allāh's reign (996-1021 CE), they hail from a sectarian Ismaili movement. Their faith stems from the belief that al-Hākim was the tenth and penultimate manifestation of Allāh on earth. Their leader, Hamza ibn 'Alī, orchestrated the diffusion of the Druze religion during al-Hākim's lifetime. He was assisted in this task by his contemporaries, Bahāad-Dīn al-Muqtanā and Ismā̄il ibn Muhammad at-Tamīmī.

As the preaching advocated universal proselytism, the movement's principles rapidly spread throughout the Muslim world - to Syria, Lebanon, Palestine, Turkey, Bahrain, Iraq and Persia, Yemen and India. al-Hākim disappeared in $1021 \mathrm{CE}$, plunging the community into the messianic expectation of his return. When Hamza withdrew from public life that same year, he predicted that the Muslims would severely persecute the newly formed Druze community to test its faith. The Druze, fleeing persecution in Egypt (1021-1026 CE), found refuge in the Syrian-Lebanese mountains. In 1043 CE, Bahäad-Dīn, who had remained the sole leader of the movement, finally announced that the community was closing its doors to new hopefuls. He guaranteed his members that they would be reborn within the group until the return of al-Hākim, on the condition that they abide by the principle of endogamy (Oppenheimer 1980: 623).

Belonging to this community was from this moment seen as a law written "into the flesh" from birth, governing both alliance and reproduction, just as it rules out the prospect of any apostasy: the soul being immutably Druze, its nature cannot be altered by converting to any other faith. The central features of the Druze community were thus beginning to emerge: the restriction placed on the number of disciples, the refusal to establish the belief system as a dominant faith and the defiance of all non-Druze authorities and collective solidarity, still alive after nine centuries of history (Callebaut 2000: 19).

The Druze view the historical narrative that their religion ( $\operatorname{din}$ ) emerged during the eleventh century as incorrect, believing instead that their faith is the basis for the three monotheistic religions. This ever-present faith was passed on by the unitarian schools of Babylon and ancient Egypt, ancient Greek philosophers and gnostic pre-Christian communities. Referred to by the Druze as a "unitarian religion" (tawhìd), it represents a religious system all of its own. Specifically, it is based on an Ismaelian idea with Neoplatonic accents: the world and existence - humanity included - are an emanation of Allah: they form an undivided whole. Coming ever close to Allah and knowing and understanding Him are acquired through action, in the piety and devotion of the heart, without the mediation of ritual observances or human intermediaries. Such closeness 
is perfected life after life. The reincarnation of the soul is central to the Druze community. This is an instantaneous process: it occurs at the moment of death when Allah breathes the deceased's soul into the body of a newborn Druze and entrusts its care to its progenitors.

The scholarly literature usually associates the Druze religion with the Muslim faith, although it seems as different from Islam as Islam is from Christianity or Christianity from Judaism (Bryer 1975: 239). Muslims view the Druze doctrine as heresy specifically because it extols the transmigration of souls (taqammus al-arwāh) and the repeal of religion. The treatment of women in particular distinguishes the Druze collective from the Muslim collective: the Druze legislation on personal status prohibits polygamy and the remarriage of divorced wives, both of which are allowed under Islamic law. Furthermore, the Druze give women priority access to places of worship, the Book of Wisdom and religious institutions. In the direct legacy of Sufism, they assume that the female body is the metonymy of the divine - in other words, it is a source of life.

Druze men and women are expected to enter religion in each of their reincarnations. They enter through a solemn promise on the Book of Wisdom and gain full access to it. Women are not required to acquire religion through learning. Since they are called upon to bring forth life, they "are born with religion" (bikhlaqū ma' ad-dìn). Every Druze locality has its own khilwa (pl. $k$ hilwāt), a place of worship devoid of any furniture or decoration that serves as the basic unit of religious organisation. The $s \vec{a}^{\prime}$ is (from $s \bar{a} s a$, lit. to guide or to rule) or imam, who heads the khilwa, is in charge of the religious community of the village.

From a sociological point of view, one major point of differentiation is at work in the Druze community: between men and women primarily, but also between elders and the young who owe them respect, between those who have access to the Scriptures (mutadayyinin) and those who do not (juhhāl), between patrilineages and, finally, between villages with strong individualities. This principle is offset by belief in taqammus in the extended Druze community, which neutralises any differentiation according to clan, generation, and space since all group members are bound by the same "soul kinship" (qarābat ar-rūh).

\section{Methodological and epistemological considerations}

What can it mean to study taqammuṣ in a community that appears to confine it to a strict intracommunity realm of understanding and communication? Under what conditions can it be usefully examined and understood? 
As an object of knowledge reserved exclusively to the group, the transmigration of souls, according to the Druze, concerns all human beings: its existence is referred to in the three monotheistic religions. Developed and narrated in an intragroup mode, such knowledge is central to everyday life: "The transmigration of souls is an empirical fact. We believe in it as surely as we eat and drink", a friend once told me, adding: "For us, death does not exist. It is simply a transition between two lives: you die... and a few minutes later you're drinking your mother's warm milk". In this context, practices to commemorate death are kept to a minimum. While the Druze have cemeteries (maqābir), graves are unnamed and are never visited. Finally, marked expressions of grief and bereavement are frowned upon (cf. article by Samaha in this volume).

During my research in Israel, I found the discourse surrounding taqammus to be characterised by a kind of "expressive opacity" (Throop 2008: 416). I began by collecting large amounts of data which I collated through my interview partners' silence, allusions and humour. I routinely witnessed scenes in which the transmigration of souls was the subject of conversation. For example, in the presence of a newborn prone to crying a lot, it was not uncommon to hear people saying such things as: "When he died, he probably left behind a wife and young children". Likewise, in referring to someone they disliked, my interviewees would often say: "Let's hope we don't get born at her house and she doesn't get born at ours!" Lastly, I once heard a mother becoming irritated with her young daughter. Exasperated by her nonchalant approach to household chores, she exclaimed: "I hope your [future] mother is [already] pregnant with you!"

Found in many parts of the world, the notion of "reincarnation" has a complex genealogy, rooted as it is in a circulation of knowledge between continents (Guenzi and D'Intino 2016: 49). The concept has been the object of extended research, from native North Americans to Melanesia, through Africa, Australia and Asia (i.a. Mills and Slobodin 1994; Stevenson 1980; Gupta 2002; Bernstein 2013; Zivkovic 2014; Playfair 2006). The clinical and anthropological literature devoted to the Druze belief in taqammus approached it from Eurocentric perspectives: focused on the figure of the nattiq or reincarnated child (fem. nātqa, lit. he/she who speaks) and their stories of their past life, the clinical literature has tended not to stray far from the question of truth and falsehood, focusing its energies on verifying the child's statements (Stevenson 1980, 1987). The reincarnated subject (nätiq) is thought to be a divided subject, a victim of dissociative disorders prone to paramnesia. At best, the child is endowed with extrasensory perception. In another sense, recollecting - and narrating events from a past life may be seen as a "therapeutic" tool (Dwairy 2006: 48) 
that helps with mourning and handling traumatic events - a particularly valuable resource in a post-conflict country such as Lebanon (Littlewood 2001).

As for the anthropological literature devoted to taqammus, its implicit focus has been on narrative material. It has tended to view recollections of "reincarnation" exclusively in terms of political strategies and statements of prestige, the assumption being that recollections of past lives serve to build privileged relationships between unrelated individuals (Rivoal 2000: 109-110; Bennett 2006: 103). Another assumption is that Druze children are encouraged to reconstruct and recreate the narrative of their previous reincarnation from the moment they learn to talk. They invariably find a richer or more powerful family than their current one in a neighbouring community. Generally ratified, transmigration is thus thought to lead to the emergence of wide and diffuse family relationships (Oppenheimer 1980: 629; Khuri 2004: 101-116).

To summarise, what we have here are exogenous interpretations with a marked tendency towards generalisation: often troubled and dissonant, the experience and affects of subjects tend to be singularly absent. Significantly, the fact that the Druze are highly divided over the question of encouraging the genesis of stories in children is not given a mention.

What heuristic tools should we be looking to develop in order to study the transmigration of souls among the Druze? As will be clear by now, taqammus fundamentally disrupts Cartesian categories of time: death is not an end, but rather the very condition of life. Generational time is cancelled out, undermining the notions of filiation and authority: for example, since I can be reborn in this life, having been my grandmother in a previous life, I am potentially my own descendant. The notion of personhood therefore has fluid, permeable contours. Such a view is far removed from the Cartesian postulate of the subject conceived as an autonomous and relatively unified entity, with clearly defined boundaries and that cannot inhabit a plurality of bodies (Robertson 2011: 585). In the world of the Druze, the subject is troubled by a degree of opacity, simultaneously oneself and someone else, deceased but returned to life in a new body. Rather than limiting themselves to the timespan of a single life trajectory, each person's relationships with others are destined to endure and to be reconfigured through "posthumous modes of presence" (Zivkovic 2014: 39).

Thus, as understood by the Druze, taqammus draws our attention to the invisible dimension of reality (al-bātin) concealed behind the appearance of forms. The concept challenges the division between cognition and bodily consciousness that shapes our understanding of our existence, but also the division between subjective experience and the external world, between sentient beings and deceased beings (Zivkovic 2014: 105). In this sense, taqammus highlights 
the limits of conventional anthropological methods, based on visual inquiry (Mittermaier 2015: 112). To investigate the transmigration of souls in the world of the Druze is an invitation to enter an active intersubjectivity, to cultivate "modes of somatic attention" (Csordas 1993) - of availability, attentiveness, co-presence and reciprocity. The point here is not to determine whether souls "that return" through reincarnation exist. We should instead "take seriously the experiences constructed and lived" (Despret 2015: 172, my translation) by those who live their lives as reincarnated beings - without ever reducing such experiences to mental projections (Mittermaier 2015: 109).

\section{Transmigration, unitarian rhetoric and community affects}

\section{The breath (ar-rūh) and the body (al-jism)}

In Druze theology, as depicted by my interviewees and friends, the process of the transmigration of souls is deployed around the ru $h$-jism couple.

$R \bar{u} h$, meaning literally "breath", is an organic, dynamic term connoting eternity (khulüd): "The essence of man is the soul" (așl al-wähid ar-rūh); "nothing is more precious than the soul (mā fish aghla min ar-rūh)"; "the secret of life is not to be found in the body but in the depths of the soul" (sirr al-hayāt mish $\mathrm{fi}$ l-jism amma bi-r-rüh). Through its sayings, the community tells the extent to which the soul (rüh) represents the true essence of the person.

The body, the flesh (al-jism), is ephemeral and perishable. It is a "shirt" (qamiss) for "the breath", leaving the body life after life. The immortal soul is a divine property - in the sense of being owned by God. Affects are intimately associated with it, with dislikes and fears, but also tastes and affinities, being passed on, or transposed, "from life to life" (min jīl la-jīl). Certain moral qualities and ethical attitudes are also attached to the soul and cycle through life after life - such as courage, strength, patience, generosity or righteousness.

Until death undoes them, ar-rūh and al-jism are bound by a relation of necessary complementarity. "No soul without body" (mā fish rūh bidūn jism): in other words, deprived of its garment of flesh, the soul cannot experience life on earth. In return, the soul "puts the body in motion" (bi-tharrik). As "energy" $(t a \bar{q} a)$, it is the vital driving force that causes a person to act. And the quality of such action in return influences the quality of the soul.

What the Druze term the "re-enwrapment of souls" (taqammuş) has happened and happens to all human beings, in all places and since the beginning of time. Introduced by Allah, it is an instantaneous process. At the moment of death, the breath of the soul (ar-rüh) escapes the body that "had dressed 
it" (itqammașha) until then. It is then instantly breathed into the body of a newborn: the child's first cry signals the entry of the soul (ar-rüh) into flesh. Rebirth into the community of the living - which is therefore immediate - occurs according to a random pattern that pays no heed to space and time.

Allah subjects the soul to a variety of geographical, economic, sociological and health conditions, and herein lies the effect of His justice (' $a d l$ ). Every life ( $k u l l j \bar{l} l$ ) on earth is "a visit" (ziyāra); its aim is to know Allah and to unite with him. In this sense, the soul may return to the mother's or father's lineage but may also migrate to another family, village or country. There is just one rule that applies invariably: a Druze soul is always reborn within the Druze community and cannot be altered by converting to any other religion. All souls are also gendered: whether male or female, a soul remains so until the end of time that is, through its various reincarnations (in male or female form). Lastly, the Druze only recognise the passing, or transition, of souls into human forms. The number of souls is fixed.

\section{“Us Druze, we're all relatives” (iḥna drūz, kullna qarā'ib)}

The concept of kinship (qarāba), as defined by Druze society, goes beyond the confines of consanguinity (qarāba dammawiyya), described as the "proximity of body" (qarāba jismāniyya): it extends to "the proximity of soul" (qarābat ar$r \bar{u} h$, lit. proximity of the breath), the result of the transmigration of Druze souls within the community.

In other words, the importance given to consanguinity is qualified by the Druze belief in the transmigration of souls. A soul is, first and foremost, immutably Druze; it is only secondarily, and indeed only temporarily, also a member of a patrilineage, village or nation. The allegiance of the Druze community therefore invariably takes precedence over any other provisional allegiances or loyalties that may apply (Oppenheimer 1980: 627). As a friend once explained: "We marry to bring children into the world and to prolong the chain of the unitarian religion. So our religion forbids us from bonding with anyone other than the Druze: mixing blood is banned" (ihna mnitjawwaz 'ashān nkhallif w-nțawwil silsilt at-tawhìd. Dìna bimna'na nurbut màna min ghayr ad-drūz. ikhtilāt ad-damm mamnū').

As I noted above, compliance with endogamy is prescribed as the condition for Druze souls to transmigrate strictly within the confines of the community. It is the guarantor of the "kinship of breath" (qarābat ar-rūh $)$ - also described as "kinship in religion" (qarābat dìn) - that connects members of the group, alongside blood ties (qarābat damm). As an interview partner put it: "Us Druze, we marry amongst ourselves (literally: we do not take and 
not give [girls]). So we die and are born amongst ourselves" (ihna drūz, la mnōkhod, la mnàțī. ihna minmūt w-mnikhlaq bass min 'indna). Beyond family solidarity, all Druze are potentially relatives: they were relatives in a previous life and will be relatives again in a future life. The Druze summarise this fact by holding that "death does not exist and the taqammus keeps us close" ("indna mā fish mūt wa-t-taqammus bikhallina qrāb). "We are a single family"; "we are all brothers and sisters"; "related to one another"; "we are all parents"; "we are a single blood"; "we are the fingers of a hand"; "we are a single cloth"; "we are a single fabric of interwoven threads": through its unitarian rhetoric, the group reminds us of the extent to which collective consanguinity, founded on the rejection of sexual relations with non-Druze, is a guarantor of ideal kinship. The implication of this is equality (tasāwi $)$ between members of the community - between men and women, old and young, religious and non-religious. What follows is the religious injunction of "protection and mutual assistance" (hifz al-ikhwān).

Shaped by confinement to Druze blood, the continual return of souls to the group finds itself implicitly erected into a factor of "proximity" (qarāba) acting as the very foundation of a community of shared affects. As a friend explained enigmatically: "Just as we protect the blood, so the blood protects us. Whether my Druze brother comes from Lebanon or Syria, I feel compassion for him because he may be born in my home or I may be born in his" (minhäfiz ' $a$ - $d$ damm wa-d-damm bihâfiz 'alayna. idha akhūy ad-durzī ija min lubnān walla min süryā, bashfaq 'alayh. ma'qūl yikhlaq 'indī, walla bikhlaq 'indu). As the guarantor of affective solidarity (räbita), such proximity is experienced, or felt, organically, in the mode of reciprocal belonging. As my adoptive grandfather explained to me: "Any Druze is my brother. He belongs to me, just as I belong to him. He is one of us, with us" (kull durzī, akhī. hù ili w-ana ilu: dammī min dammu. ya' nī, hū minna $w$-fìna).

"Affection" ('atfa), "love" (mahabba) and "mercy" (rahma) are the emotions every Druze reports feeling immediately in the presence of any other Druze. On seeing a peer, "the heart of a Druze beats faster" (qalb ad-durzì bukhfuq) and "his blood becomes warmer" (damm ad-durzì but tuf 'a-d-drūz). What follows from this is the proud claim that a Druze always recognises another Druze in non-Druze settings.

What are the implications of this taqammus discourse and unitarian rhetoric for the social fabric of the individual? That is the question I try to answer next, by focusing briefly on care of young children. 


\section{Taqammus and the social fabric of the individual: caring for infants}

A newborn among the Druze is thought of from birth as being integrated in webs of relationships. The joy of the baby's arrival is thus a measured, reticent joy, out of compassion and empathy for the family that finds itself grieving for the loss of a relative. As my friend Rashida stated:

I know my son belonged to people other than me. People are sad because they have been left behind. I can't allow myself to be too happy. He may have left a wife and children behind. He may have died in the prime of life (bárif ibnī kān la-nās tānyìn. $f \bar{\imath}$ nās za'lānìn 'alayh. mish läzim akün farḥ̂na kthìr. mumkin tarak wläd zghär w-mara. mumkin hū māt shābb).

From a Druze perspective, compassion ( $\mathrm{rahma}$ ) and generosity (karam) must be given to the child, who belonged to other places and who left everything behind. Exiled from "house to house" (min bayt la-bayt), "he arrives as a visitor" (jäy dayf) in the house into which he is born.

"I have four children who belong to Allah", as one neighbour told me on introducing herself to me. As a "divine possession" (mulk la-allāh), a child is "divine manna" (al-walad ni ma), "entrusted to a household" (al-walad amāna "ind al-ahl) as part of a pact with its members. His parents are required "to behave as hosts towards him" (läzim yistaqblüh). It is their duty to protect him and to ensure he stays in good health - in short, "to be there for him" ( $y k \bar{u} n \bar{u}$ fì hammu).

At first, shaped by his past bonds, a newborn is the "non-similar" one. As for the host, "nothing is known of him at first". It is therefore vital for his household to give him "the best welcome" (ahsan astiqbäl). With warmth and respect, he is "welcomed" (bit'ahhlū fìh), seen as the adult that he is. As my friend Leyla confided: "Of course, he is a baby and he has a small body. But he has the soul of an adult" (hū walad zghīr, jismu zghìr. amma rūhu rūh. wähda kbīr). Leyla went on to explain: "When I hold a newborn in my arms for the first time, I say to him: 'Welcome! We love you. You are a good person. Your parents are good people"” (lamma bākhud tifal awwal marra, baqul-lu: ahlā w-sahlā fìk! ihna minhibbak. inta mnīh. ahlak mnāh'i).

Mothers even acknowledge that their maternal feelings emerge only gradually. While the child is one flesh with the mother, his soul is, initially, radically alien to those welcoming him into their home. As the Druze see it, "throughout his life" (kull hayātu), "a bond of breath" ('alāqa rūhāniyya) will survive with his previous family. 
Given this, a baby is not welcomed as a new being who gradually finds his way in the world (Gupta 2002: 33). Instead, his past lives are believed to form a vital part of his personhood (Bernstein 2013: 72) - of who he is as a person. His states of wakefulness and sleep reflect his memories and his desires. They are the object of sophisticated attention. As matter for interpretation, they give rise to discourse about them - explanations, but also excuses or jokes. My friend Jamilli once told me: "When my son cried, I would say to him: 'Don't you like me? Was your mother prettier than me?' It's true, you don't know where your child comes from, nor what he was. Perhaps he's a Druze from Lebanon or Syria. Perhaps he had to leave young children behind, a wife, a mother ...”.

Whether they were Druze from Lebanon or Israel, my interviewees maintained that during the first months of existence, the soul of a child "is resting" (bi-tastarih) after a presumably tiring life. During sleep, she "remains with her previous parents" (bitdall ma' ahlu fì $l$-jīl hādāk): she "joins them and speaks to them" (btisrah w-bitkallim ahlu). Those are just some of the words used to explain the sleepiness, or drowsiness, of newborns, interspersed with smiles, but also, at times, screaming and crying.

Similarly, my interviewees would speak of a calm baby who sleeps a lot as having "died an old man" (māt khityār): "satisfied with life" (sha'bān min addunya), he has no memory of those he lost. By contrast, a baby who cries a lot or is irritable is assumed to have "died a young man" (màt shābb), no doubt leaving a wife and children behind. Thus, tormented by the memory of his family, he remains conscious, guilty at no longer being able to provide for them. The point is that "the soul feels" (ar-rūh bi-thiss) the sorrow or serenity of those it left behind, susceptible to the affects of others.

More generally, it is believed that grieving for the dead affects the soul of the newborn, who will grow up feeling oppressed and tormented. Additional maternal patience is thus required. Conversely, comforting words give solace to the relatives of the dead. Through a feedback effect, they serve to soothe the child. Of a newborn who sleeps deeply and who grows up "calm and wise" (sākit w-'àqil), it is said that his previous family "remembers him well" (ahlu bi-tdhakkiru jayyid).

\section{Ethics, agency and Druze subjectivities}

Psychoanalysis teaches us that the subject constructs herself by accepting the difference between the sexes and between generations, that she is unique that is, herself and not another - and that she accepts absence and separation (Conrotte and Armanet 2012: 2). As a friend of mine - a clinician - once asked 
me: "With its logics of endogamy and purity of blood so at odds with the foundations of psychoanalysis, how is it that the Druze community is not sick?"

As I noted above, the Druze community has survived for nearly ten centuries, resisting persecution and maintaining a strong identity despite its position as a minority faith. So how does it cope with an endogenous principle of identical reproduction, the general effect of which is communal uniformity? To what extent is the community able to construct differentiation? If it is able to do so, what are, ultimately, the forms of subjectivity that it constructs?

The European understanding of the subject is rooted in the legacy of a binary and logocentric Cartesian ontology that postulates the existence of a full, unified and wilful subject "freely forging social relationships and not forged by them" (Supiot 2005: 49, my translation). Foundational, such a being is enamoured of autonomy.

The Druze belief in taqammus challenges the model of the secular and liberal Cartesian self, leading us to question the limits of the interiority of the subject. As a Druze, I exist by virtue of belonging: a divided being, I am both myself and so many others because of my successive lives. Any Druze belongs to me, just as I belong to him: any Druze is my brother since "my blood is also his blood" (dammi min dammu). In other words, for the Druze, existence is a fluid, intercorporeal and intersubjective field of life.

Far from dismissing the question of agency and responsibility, belief in the transmigration of souls is an invitation to consider an ethics that extends beyond an autonomous, clearly demarcated subject (Mittermaier 2012): every Druze is assured of being acted upon. Included in the ontology of the reproduction of the group, the notion of "destiny" (nași $b$ ) determines the course of each individual's life. At birth and death, destiny "occurs" (bijji an-nașib), the sign of the enduring union of Allah with the community. Behind the opacity of everyday life and its apparent arbitrariness, one thing is certain: Allah decides. In the threads of the lives, Allah forms, undoes or leaves in suspension, allowing the divine presence to be sensed and seen. Nothing is gratuitous or pure coincidence. Every event is bound to a cause that goes beyond it and precedes it.

In its unpredictability, the transmigration of souls escapes the control of the group and the stranglehold of religious elders (mashāyikh ad-dinn): it cannot be directed. In this sense, it offers the subject the possibility of leaving behind her present affiliations (whether family, lineage, village or national affiliations) to enter a plurality of potentially new bonds and spaces (Oppenheimer 1980: 627). This unpredictability of the transmigration of souls leads to processes of subjectivation: it is important to remember that, in most cases, the identity of the reincarnated subject is not known, but assumed, spoken and imagined - so 
there always remains an element of the unknown. We might then speak of Druze agency, not as a power for self-determination but as a power founded on a capacity for acceptance, consent to the world, patience and receptivity (Plancke 2014: 332).

But if every subject is aware of being acted upon - and indeed values the fact of being acted upon - belief in the enduring reincarnation of souls also inspires in the subject a unique ethical attitude at the service of the community. Far from cancelling out individual responsibility, the fact of knowing that one is acted upon increases the capacity and the obligation of the subject to respond (Mittermaier 2012: 261). The aim is to establish, from life to life, "a well-acting" ('amal, maslak) in an acquiescence to the group and its practices of retreating and keeping to oneself (tasattur).

While every reincarnation occurs according to a seemingly random divine scheme, the ethical behaviour of each person in their present life - and the nature of their actions - can at least inflect the conditions of their future existence. Conditioned as they are by the laws of causality, our lives and the moral choices we make within them, so the Druze believe, shape our destinies, step by step. They affect the circumstances of our future lives at our next rebirths. In this sense, the subject is the ally of Allah - and to an extent, the co-decider and co-entrepreneur, as a friend of mine, Nabīl, explained:

We are like a train on rails... Before launching ourselves on the rails, we laid down a choice. Since then, our choice has forced us to continue down the same path. So, free will or determinism? Both simultaneously. Every effect has a cause, which precedes it. . But we have a degree of relative freedom to shape our destiny. Not everything is mystical, metaphysical or supernatural: we are free to create on earth both the conditions of Heaven and those of Hell. We cooperate with Allah: we experiment, we improve, we repair. .. And all of this is played out here and now, in the present.

Here, the sovereignty of every subject resides in her capacity to "contain and control the body" - in the habit "of modesty" (ziyy al-hishma), in space, in speech - in order to better care for the soul. The body is the temporary medium through which the soul gains access to further intimacy and integrity. The point is also to integrate oneself into the ethical project of the group, where the emphasis is on communal sharing and humility. This ethical project is a command to endless "good deeds" (hasanat), to the protection and support of peers.

What happens at the end of a life? After achieving completeness through the domestication of their body, each subject anticipates their next rebirth. Having entered religion, the person learns to extricate herself from temporary allegiances and loyalties (whether to a family, a village or a nation) in order to 
be able to enter a plurality of potentially new bonds and spaces in the next life. Is it a case of undoing one individuation before entering another? Not really. The point is to move from appearance ( $z \bar{a} h i r$ ) to intimacy (bātin) (Rivoal 2016: 24). Asceticism, self-effacement and physical discipline are the cardinal virtues for which every subject has a duty to strive.

\section{Conclusion}

Despite the prescription of endogamy and identical reproduction, the Druze belief in the transmigration of souls constructs a subject from an encounter with alterity borne by reference to both Allah and the community. This construction implies a drastic treatment of personhood (Conrotte and Armanet 2012: 4): there is no place for a unique and singular being here. In this sense, where the discourse of the hard sciences today shapes the subject into an object, as part of an obsession with what is measurable and visible, the Druze discourse offers by contrast "a capacity for symbolisation - and, therefore, humanisation" (ibid, my translation).

Does the Druze belief in the reincarnation of their souls come from a society that is today "under siege" (de Heusch 1961: 34), in our neoliberal world? To answer this question, I give the last word to my Druze interviewees. As many of them claim, "the world is expiring" (ad-dunya $b$-äkhir waqt), living as we do in times of deviant openness and outpourings - of unveiling. But we are talking here of the maternal, cyclical temporality of the Druze. And so my interviewees are careful to add: "The world is a mother. It is pregnant with a new world, whose date of birth no one knows" (ad-dunyā imm. ad-dunyā hāmla min dunyā jdìda. mā hada bi rif waqt at-takhlīf).

\section{Acknowledgements}

Special thanks to Rob Reay-Jones for finalising the (French to English) translation of my text.

\section{Literature}

Armanet, Eléonore. 2018. 'Allah has spoken to us: we must keep silent.' In the folds of secrecy, the Holy Book of the Druze. In: Religion. Routledge, Taylor \& Francis, 48 (2), pp.183-197. DOI: ff10.1080/0048721X.2017.1386370ff. ffhal-01789462.

Bennett, Anne. 2006. Reincarnation, Sect Unity, and Identity among the Druze. In: Ethnology, 45(2), 87-104. 
Bernstein, Anya. 2013. Religious Bodies Politic: Rituals of Sovereignty in Buryat Buddhism. Chicago: University of Chicago Press.

Bryer, David R.W. 1975. The Origins of the Druze Religion. In: Der Islam, 52, 239-262.

Callebaut, Paul-Jacques. 2000. Les mystérieux Druzes du Mont-Liban. Bruxelles: La Renaissance du livre.

Conrotte, Joëlle and Eléonore Armanet. 2012. " De l'exil et des âmes. Entre clinique et anthropologie: regards croisés sur des récits de rêves ", 14ème colloque de la revue L'autre: "Rêves d'exil, exil des rêves. Pratiques ethnopsychiatriques avec les familles migrantes”, 6 et 7 décembre 2012 (Luxembourg), unpublished manuscript.

Csordas, Thomas. 1993. Somatic Modes of Attention. In: Cultural Anthropology, 8(2), 135-156.

De Heusch, Luc. 1961. À la découverte des Tsiganes. Bruxelles: Institut de sociologie de l'Université Libre.

Despret, Vinciane. 2015. Au bonheur des morts. Récits de ceux qui restent. Paris: La Découverte.

Dwairy, Marwan. 2006. The psychosocial function of reincarnation among Druze in Israel. In: Culture, Medicine and Psychiatry, 30, 29-53.

Guenzi, Caterina and Silvia D’Intino. 2016. Du karma et de quelques pratiques de réminiscence des vies antérieures. In: Terrain, 46-61.

Gupta, Akhil. 2002. Reliving childhood? The temporality of childhood and narratives of reincarnation. In: Ethnos, 67 (1), 33-56.

Haddad, Yvonne Y. and Jane I. Smith. 1993. The Druze of North America, in: Haddad Yvonne, Y. and Jane I. Smith (eds.), Mission to America: Five Islamic Sectarian Communities in North America. Miami: University Press of Florida, 23-48.

Khuri, Fuad I. 2004. Being a Druze. London: Druze Heritage Foundation.

Littlewood, Roland. 2001. Social Institutions and Psychological Explanations: Druze Reincarnation as a Therapeutic Resource. In: British Journal of Medical Psychology 74(2), 213-222.

Mills, Antonia and Richard Slobodin (eds.). 1994. Amerindian Rebirth: Reincarnation Belief among North American Indians and Inuit. Toronto: University of Toronto Press.

Mittermaier, Amira. 2015. Dreams and the miraculous. In: S. Altorki (ed.), A Companion to the Anthropology of the Middle East. John Wiley \& Sons, 107-124. 
Mittermaier, Amira. 2012. Dreams from elsewhere: Muslim subjectivities beyond the trope of self-cultivation. In: Journal of the Royal Anthropological Institute, 18 (2), 247-265.

Oppenheimer, Jonathan W.S. 1980. 'We are born in each others' houses'. Communal and patrilineal ideologies in Druze village religion and social structure. In: American Ethnologist, 621-636.

Plancke, Carine. 2014. Flux, rencontres et émergences affectées. Pratiques chantées et dansées chez les Punu du Congo-Brazzaville. Toulouse: Presses Universitaires du Mirail.

Playfair, Guy L. 2006. New Clothes for Old Souls. Worldwide Evidence for Reincarnation. London: Druze Heritage Foundation.

Rivoal, Isabelle. 2000. Les maîtres du secret: ordre mondain et ordre religieux dans la communauté druze en Israël. Paris: Ed. De l'École des Hautes Études en Sciences Sociales.

Rivoal, Isabelle. 2016. Le sens de la relation (3 vol.), Anthropologie sociale et culturelle, Université de Paris Ouest, Nanterre La Défense. https://hal. archives-ouvertes.fr/tel-01419139/document

Robertson, Alexander F. 2011. How can Lukoho be his own grandfather? Being and becoming in the Cartesian gap. In: Journal of the Royal Anthropological Institute, 17, 585-603.

Roussel, Cyril. 2004. Communauté et mobilité: les nouveaux refuges des Druzes de Syrie. In: Les migrations internationales. Observation, analyse et perspectives. Colloque international de l'AIDELF, Budapest, 313-326.

Stevenson, Ian. 1987. Children Who Remember Previous Lives: A Question of Reincarnation. Jefferson: McFarland \& Co Inc.

Stevenson, Ian. 1980. Cases of the Reincarnation Type, III: Twelve Cases in Lebanon and Turkey. Charlottesville: University of Virginia.

Supiot, Alain. 2005. Homo Juridicus. Essai anthropologique sur la fonction anthropologique du Droit. Paris: Seuil.

Throop, Jason. 2008. On the Problem of Empathy: The Case of Yap, Federated States of Micronesia. In: Ethos, 36 (4), 402-426.

Zivkovic, Tanya. 2014. Death and Reincarnation in Tibetan Buddhism. New York: Routledge. 

Lorenz Nigst ${ }^{1}$

\section{Leaving Things in Abeyance: Druze Shaykhs Speaking About Transmigration on TV}

\section{Introduction}

If there is any elaborate "secret" Druze teaching about transmigration (taqammuss), it is not accessible. The so-called canonical Druze scriptures or "Epistles of Wisdom" (i.e. the Rasẩ il al-hikma), of which critical editions now exist (see de Smet 2007), contain only few direct references to transmigration (see de Smet 2013: 87). The scope and content of the juwwānì or "internal" literature, with important exceptions such as the "book of points and circles" in this process, Kitāb an-nuqat wa-d-dawä'ir by Zayn ad-dīn 'Abdalghaffār (d. 1557 $\mathrm{CE}$ ), which explicitly broaches the topic of transmigration, is for the most part unknown to the general public. ${ }^{2}$

This chapter rests on the observation that representatives of the Druze religious establishment at times face the expectation to discuss the topic of transmigration during public appearances on TV. "The Druze" are not only known for believing in transmigration and their specific understanding of it; ${ }^{3}$ the

1 Lorenz Nigst is currently working with the KITAB project, a project that has received funding from the European Research Council (ERC) under the European Union's Horizon 2020 research and innovation programme (Grant agreement No. 772989).

2 For the term juwwāni literature, see Firro (2011: 92-98). Obviously, the fact that this literature is for the most part unknown does not imply that it contains relevant material. See Seybold, Christian 1902: Die Drusenschrift: Kitāb Alnoqaṭ Waldawāir. Das Buch der Punkte und Kreise. Leipzig: Kirchhain N.-L.

3 As early as the twelfth century CE, Benjamin of Tudela pointed to the Druze belief in transmigration in his itinerary. See Benjamin of Tudela 1840, vol. 1: 61-62: “They say that the soul of a virtuous man is transferred to the body of a newborn child, whereas that of the vicious transmigrates into a dog or some other animal". Although elements of this description such as the transmigration into animal bodies are not accurate, Druze today frequently state that the soul migrates to the body of a newborn. The similarity with statements made by Druze today is more manifest in an alternative translation of the same passage: “They say when a good Man dies his Soul immediately seizes the Body of some little Infant, which is born at the very same Instant in which the Soul departed from the Body of the Man" (Benjamin of Tudela 1784: 66). 
phenomenon of "speaking" (nuṭ) flares up everywhere in Druze communities. This phenomenon typically involves children who "speak" (națaqa) about a previous life in another family, which is occasionally identified, thus pushing transmigration from the level of general thoughts about the soul to particular people in the social world. Due to such cases (hālāt, sg. hāla) of "speaking" and the perception of some Druze that they had previously been a different person in another family, the topic of transmigration enjoys some notoriety (see Dwairy 2006; Bennett 1999; French 2016; Stevenson and Haraldsson 2003; Haraldsson and Abu Izzedin 2002). Especially in talk shows, such cases might easily take a turn towards the sensationalist, alongside other topics that promise high viewing figures. ${ }^{4}$

The contexts in which members of the Druze religious establishment are requested to discuss the topic on TV reflect this twofold presence of transmigration as a general idea perceived to be characteristically Druze and as concrete cases involving specific people. The statements made in such contexts constitute an interesting complement to material from anthropological fieldwork and shed light on the complex Druze discourse on transmigration.

Transmigration occasionally comes up in more extensive interviews with eminent Druze shaykhs. Examples are Sāmī Abī l-Munā’s appearances on

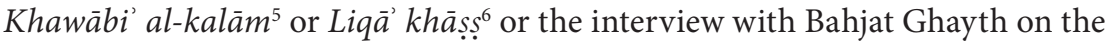
programme Tahaddiyāt. ${ }^{7}$ In this context, transmigration is neither the reason for the interview nor at centre stage. Rather, the host of the TV programme might broach the topic at some point as something for which the Druze are "famous". Representatives of the Druze religious establishment may be asked to explain taqammus in documentaries about the Druze as a religious group, such as Al-Jazeera's Al-Mujtama'ät ad-diniyya. ${ }^{8}$ Again in this context, transmigration

4 For example, an episode of Tony Khalifeh's TV show Al-Ayn bi-l-ayn (see below) stages a woman who claims to have been murdered, remembering details of her killing and the place where it happened, etc. See https://www.youtube.com/watch?v=XGNTgQ-0iM (accessed 20 June 2018); min 38:05 ff.

5 Available at: https://www.youtube.com/watch?v=rLOUm2A1K_E (accessed 20 September 2018).

6 Available at: https://www.youtube.com/watch?v=ZgEBuxENpN0 (accessed 20 September 2018).

7 Available at: https://www.youtube.com/watch?v=djiLZb2RzAo (accessed 20 September 2018); the link is to the first part only.

8 Available at: https://www.youtube.com/watch? $v=B t 60 o r o n J 3 U$ (accessed 20 September 2018). 
and its potential social repercussions are typically addressed as a characteristic element of the Druze belief system, without being the exclusive focus.

Members of the Druze religious establishment occasionally participate in documentaries, talk shows and studio discussions dedicated specifically to transmigration and often involving individuals who allegedly remember a previous life and "spoke" in their childhood. One such programme is an episode of Al-Arabiyya's Muhimma khāșsa. ${ }^{9}$ Notable examples of talk shows include two episodes of Al-Ayn bi-l-'ayn ${ }^{10}$ and $1544,{ }^{11}$ both hosted by Tony Khalifeh. One studio discussion about taqammuṣ is an episode of Fi falak al-mamnü', broadcast by France $24 .^{12}$

\section{How do members of the Druze religious establishment speak about transmigration in such contexts?}

There may not be a general answer to this question. Nevertheless, it is clear that the task of publicly speaking about transmigration is difficult and sensitive. Speaking about transmigration in a TV setting requires navigating between something which is of crucial conceptual importance for most Druze as a community and the often-held view from the outside that the proposition that "souls migrate" is either absurd or heretical. ${ }^{13}$ Speakers may not want to talk about aspects of the subject; not least, it requires navigating between respect for highly personal accounts by Druze who perceive that they remember a previous

9 Available at: https://www.youtube.com/watch?v=Kp_kNBIyykc (accessed 20 September 2018).

10 Available at: https://www.youtube.com/watch?v=XGN-TgQ-0iM (accessed 20 September 2018).

11 Available at: https://www.youtube.com/watch?v=DzZbQp22R9A (accessed 20 September 2018).

12 Available at: https://www.youtube.com/watch?v=uN4levEgl0Y (accessed 20 September 2018).

13 Transmigration is clearly connoted with heresy in a Muslim environment and continues to be highlighted as an element of Druze theological aberrance. See, for example, the publication (Anonymous) 2013 CE / 1434 AH: Risāla fì hukm ad-Durūz wa-n-Nuşayriyya al-'alawiyya al-musammāt: aqwāl al-a'imma al-'ālina fī hukm adDurūz wa-t-Tayāmina li-muftì ash-Shām al-'allāma Alì al-Murādì tuwuffiya $1183 \mathrm{AH}$ / 1771 AD wa-maiahā: fatwa fì hukm ad-Durūz wa-n-Nuṣayriyya li-muftì ash-Shām al-'allāma 'Abdarraḥmān al-Imādī. Dimashq and Halabūnī: Dār Bilād ash-Shām. For al-'Imādî's fatwa against the Druze, see the manuscript MA VI 141, 44r-47r held by the University Library of Eberhard Karls Universität Tübingen. 
life and concerns that "speaking" may lead to torn lives. Druze shaykhs navigate between these conflicting perspectives and requirements with an often admirable sense of responsibility and tactfulness. It is hard to dissipate the impression that they do so by "taking the edge off" taqammus as "dogmatic content" of the Druze belief system and "speaking" as a phenomenon in the social world. Most notably, it is through leaving things in abeyance that they gain some time and space. This room for manoeuvre can accommodate diverse beliefs, doubts, and thoughts, without revealing one's own beliefs. It is plausible that this strategy is largely synonymous with leaving unanswered/unanswerable the question of whether transmigration, and individual cases of "speaking", are "true". Obviously, "true" refers to two different things: propositional content and cases of "speaking". The first corresponds to the question of whether the sentence that "souls migrate to a new body immediately after the death of the old body" is an adequate description of something true for all human souls. The second usage of "true" corresponds to the question of whether someone's "speaking" "really" verbalises memories of something that happened in a "previous life". Efforts to "take the edge off" transmigration comprise both dimensions of "truth".

\section{Leaving things in abeyance: Is the notion that souls migrate an adequate description of what really happens?}

It is remarkable that in televised statements and discussions, members of the Druze religious establishment occasionally reframe the issue of "transmigration" with recourse to Qur'anic verses and the terminology of Islamic jurisprudence. This suits occasional arguments that the Druze are only one Islamic "school of thought" (madhhab) among others. ${ }^{14}$ Referring to a Qur'ānic verse (Q 3:19), for example, Lebanese Druze shaykh Sāmī Abī l-Munā emphasises that "the religion with God is Islam"15 and that "[w]e are Muslims, thank God!" 16 They do this in a way that largely dissipates the notion that transmigration is a specifically Druze idea, much less the essence or a core pillar of their

14 Most notably, the idea that there is something like a "Druze religion" is occasionally rejected. Being Druze is tantamount to forming part of a particular maslak or madhhab.

15 See https://www.youtube.com/watch?v=XGN-TgQ-0iM (accessed 4 July 2017); min 12:00 ff.

16 Shaykh Sāmī Abī l-Munā; see https://wwww.youtube.com/watch?v=ZgEBuxENpN0 (accessed 4 July 2017); min 36:17 ff. 
belief system. Thus, they point to the importance of transmigration in Greek philosophy and qualify the role of transmigration in the Druze faith through two main lines of reasoning (characterised as two "opinions" within the Druze community, both of which deserve respect).

(1) The Druze shaykhs hint that they would prefer to keep with the Qur'ānic statement (Q 17:85) that "[t]he rüh [soul] is one of the things, the knowledge of which is only with my Lord. And of knowledge, you [humankind] have been given only a little" (ar-rūhu min amri rabbì wa-mā ùtìtum mina l-ilmi illā qalì $\bar{a}) .{ }^{17}$ That is, they would prefer not to talk about the issue of transmigration and the fate of the human soul at all. Sometimes, they explicitly connote this stance with religious authority and rank. Shaykh Mursil Naṣr illustrates this stance in Tony Khalifeh's TV talk show 1544, when he characterises it as the "opinion to which our venerable shaykhs cling" (ra'y...yatamassak bih $\bar{\imath}$ shuyūkhnā al-ajillā') ${ }^{18}$ and as "that to which the shaykhs adhere" (hädhā $m \bar{a}$ yaltazimu bihi sh-shuy ūkh). ${ }^{19}$ This position is furthermore characterised as the mawqif shar $i,{ }^{20}$ that is, as conforming to the Qur'ānic text (Q 17:85) given above. $^{21}$

(2) Despite maybe articulating a preference for entirely refraining from speculations about the soul (rüh), the Druze shaykhs take care not to discard the discourse on it and reframe the related inquiries as ijtihād. ${ }^{22}$ The term ijtihäd immediately redefines the discourse on taqammus and those who engage in it (așhāb nazariyyat at-taqammuṣ) for a Muslim audience because it puts them on an equal footing with any other Muslim religious scholar who tries to make sense of the Islamic religious texts. If they are right, they will be rewarded twice; if they are not, they will be rewarded

17 Translation by Mohsin Khan.

18 See https://www.youtube.com/watch?v=DzZbQp22R9A (accessed 3 May 2017); min 10:22 ff.

19 See https://www.youtube.com/watch?v=DzZbQp22R9A (accessed 3 May 2017); min 12:47 ff.

20 Shakyh Mursil Nașr; see https://www.youtube.com/watch?v=euEbPA-3iaA (accessed 4 July 2017); min 20:22 ff.

21 See also https://beryte.wordpress.com/2012/02/ (accessed 24 March 2017).

22 Shaykh Mursil Nașr; seehttps://www.youtube.com/watch?v=XGN-TgQ-0iM (accessed 4 July 2017); min 57:19 ff; see also https://www.youtube.com/watch?v=DzZbQp22R9A (accessed 5 March 2017); min 10:43. 
once (idhā aṣābū fa-lahum ajrān wa-in akhṭa'ū lahum ajr wähid). ${ }^{23}$ From this perspective, the discourse on taqammus is just another attempt at "sense-making" and as such does not claim to be "the truth"; it is an "investigation into the fate of the soul" (bahth 'an mașir ar-rūh ) $^{24}$ which "deserves attention" (tastahiqq al-'ināya). ${ }^{25}$ For example, shaykh Mursil Naṣr states that "the partisans of the theory of taqammus do have arguments in which we cannot but take interest". ${ }^{26}$ Significantly, he cites a Qur'ānic verse in this context (Q 2:28): "How can you disbelieve in God? Seeing that you were dead and He gave you life. Then He will give you death, then again will bring you to life and then unto Him you will return" (wa-kayfa takfurūna bi-llähi wa-kuntum amwātan fa-ahyākum thumma yumitukum thumma yuhyīkum thumma ilayhi turja'ūna).

In this reframing, transmigration itself, not to mention its categorisation as "dogmatic belief" ('aqida), is left in abeyance: "It is a phenomenon that some place in the rank of 'aqida, whereby they hold that it is inevitable that the soul migrates immediately from a dead body to the body of a newborn. This is what some of our Druze brothers believe". ${ }^{27}$ While some state that taqammus is part of the dogmatic beliefs of the Druze ${ }^{28}$ others categorically deny this: those who have speculated about transmigration "have never insisted on taqammuṣ in the sense of an 'aqìda that would contradict any Islamic 'aqì $d a$, or any other 'aqìda such as resurrection, for example; they made an effort to understand the issue [ijtahadū fì maw dī at-taqammuș]”. ${ }^{29}$

23 Shaykh Mursil Nașr, see https://www.youtube.com/watch?v=DzZbQp22R9A (accessed 4 May 2017); min 14:53 ff. For this topic, see, for example,Krawietz (2002: 350-369).

24 Shaykh Sāmī Abī 1-Munā; see https://www.youtube.com/watch?v=XGN-TgQ-0iM (accessed 4 July 2017); min 10:35 ff.

25 Shaykh Sāmī Abī l-Munā; see https://www.youtube.com/watch?v=gwyCb12-ARI (accessed 25 April 2017); min 00:56 ff.

26 See https://www.youtube.com/watch?v=DzZbQp22R9A (accessed 4 July 2015); min 12:50 ff.

27 Shaykh Sāmī Abī l-Munā; see https://www.youtube.com/watch?v=gwyCb12-ARI (accessed 25 April 2017); min 00:36 ff.

28 See, for example, Talī‘ (2001: 17, 19-20). See also: "mawḍ̄̄ at-taqammuṣ mufāduhū

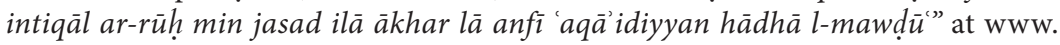
annahar.com/article/395204 (accessed 29 November 2016).

29 Shaykh Sāmī Abī l-Munā; see https://wwww.youtube.com/watch?v=ZgEBuxENpN0 (accessed 4 July 2017); min 38:30 ff. 
In essence, both lines of reasoning - refraining from relating transmigration to the soul based on Q 17:85 and reframing it as ijtihäd - are ways of expressing and recognising lack of knowledge regarding the soul. The difference is that the notion of $i j t i h \bar{a} d$ gives intellectual inquiries their social place, legitimate room (especially as they are linked to a Qur'annic verse), and permission to be pursued. The unalterable lack of knowledge, which will forever leave the issue in abeyance, removes transmigration from the matters that are beyond doubt for the Druze. As a consequence, it should not affect their lives and communities to the extent it often does. This reframing of transmigration not only effectively avoids foregrounding something incompatible with Islamic "orthodoxy" but also gives transmigration a less weighty and self-evident place within the Druze belief system. This reduction in emphasis is especially important for the phenomenon of "speaking", which Druze themselves often consider problematic not only because individual cases of it may lead to "torn lives" but also because, in the words of shaykh Ghāzì al-Halabì:

"the way people deal with the issue [of taqammus] has become increasingly folkloric and sha'bi [popular], ${ }^{30}$ with there being several cases of 'speaking' for one person. ${ }^{31}$ Thus, repeatedly, there were cases where four of five people claimed to be the reincarnation of an eminent shaykh while the soul migrates to only one body." ${ }^{\prime 2}$

\section{Leaving things in abeyance: Does the fact that someone has memories of a previous life indicate that those things really happened to him or her?}

Interestingly, in TV appearances members of the Druze religious establishment not only extend the characteristically Druze phenomenon of "speaking"

30 Druze intellectuals sometimes refer to the notion and frequent occurrence of "speaking" as a "popular phenomenon" (zähira sha'biyya); something the wider Druze population believes in (yu'minu bihā 'àmmat an-nās min ad-Durūz), but which these intellectuals feel distant to. See, for example, https://www.youtube.com/ watch?v=euEbPA-3iaA (accessed 4 July 2017); min 21:38 ff.

31 This problem was taken up in Roy Stemman's Channel Four documentary on reincarnation (see about 32:10 min); see also French (2016: 92). Our interview partners also mentioned the problem.

32 See, for example, www.annahar.com/article/395204 (accessed 29 November 2016): "bāta

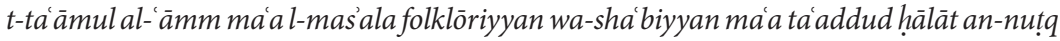
bi-sh-shakhṣ al-wāhid wa-qad takarrarat hālāt 'an arba'at aw khamsat ashkhāṣ yadda'ūna taqammuṣ rūḥ ahàd al-mashāyikh al-kibār fì hìn anna r-rūḥ tantaqilu ilā jasad wāhid faqat". 
to other confessional groups (anā ba' rif nās min ikhwannā al-masìhiyyīn hạ̄kìn $l i$-qiṣaṣ. $)^{33}$ and other societies in general ( $f \bar{i}$ kill il-mujtama' àt mawjūde). ${ }^{34}$ They also target the perception that "speaking" individuals necessarily verbalise something that really happened to them in a previous life. That is, they raise two questions: whether transmigration is what happens to all human souls after death and whether the individual case of "speaking" really verbalises previouslife memories. That may or may not be the case. They recognise that the phenomenon of "speaking" has been prevalent in the Druze communities for a long time and tends to surface again and again: "Every family has its story [of 'speaking'], in every house and in every village you are going to hear a story. Why? Because this is part of the heritage there is". ${ }^{35}$ However, in contradistinction to the idea that someone really experienced the content of respective mental episodes ( $m u s h \bar{a} h d \bar{a} t$ ) in a previous life, these episodes are reframed. It is not questioned that people see something in their minds, but maybe these are "dreams" ("yumkin ahlām") 36 or the product of their imagination (khayāl), not to mention that others might consider those "memories" the result of demonic possession (mass min ash-shayțān). ${ }^{37}$ Accordingly, people are discouraged from

33 See https://www.youtube.com/watch?v=XGN-TgQ-0iM (accessed 4 July 2017); min 49:00 ff.

34 See https://www.youtube.com/watch?v=XGN-TgQ-0iM (accessed 4 July 2017); min 49:00 ff. Several Druze publications point into this direction, see, for example, Playfair (2007).

35 " $f \bar{\imath}$ kill 'ayle fì qiṣṣa, bi-kill bayt, bi-kill day'a tisma' qiṣṣa. Lesh? Li-anna hādhā tturāth mawjūd”. See https://www.youtube.com/watch?v=XGN-TgQ-0iM (accessed 4 July 2017); $\min$ 49:00 ff.

36 Sāmī Abī l-Munā states: "I see things, but I don't know, maybe they are dreams; when I was a child, I saw houses, and I saw how I went back and forth between places". (an̄a 'indī mushāhadāt anā bass mā ba'rif yumkin ahlām wa-anā zghìr shifit byūt, shifit kint naṭit min mahall la-mahall). See https://www.youtube.com/watch?v=XGNTgQ-0iM (accessed 4 July 2017); min 49:00 ff.

37 See https://www.youtube.com/watch?v=XGN-TgQ-0iM (accessed 4 July 2017); min 48:20 ff. It is worth emphasising that much of what in Druze discourse is indicative of previous-life memories (knowledge about hidden things, xenoglossy; knowledge of past events) in other socio-religious contexts could be seen as caused by demonic agents (jinn, jānn). This is not only reflected in Sāmī Abī l-Munā's seemingly effortless inclusion of this interpretation cited immediately above. Occasional attempts are made to make sense of "speaking" through explicit references to demonic agency. One instance is found on the Paranormal Arabia website: "It is well known that the Islamic religion confirms the existence of the qarin and describes it as a type of jinn which hovers over a person and constantly is around that person as long as it lives 
declaring individual cases of "speaking" prematurely, either as a straightforward part of religious dogma (al-aqida ad-diniyya aṣ-ṣarf) or as mere dreams. They should seek the advice of the shaykhs instead.

Remarkably, it is the status of individual incidences of "speaking" which is central to the social reality and many people's experience of taqammus that members of the Druze religious establishment deliberately relegate to the category of things that will forever remain uncertain. ${ }^{38}$ They seem to raise the notion that previouslife memories might be dreams, the product of someone's imagination, or the effect of a mass min ash-shaytān, in order to push the Druze community at large away from insisting all too easily on the reality of concrete cases of "speaking". This insistence could expose them to the potentially relationship-forming force of the phenomenon. In fact, the shaykhs advise that memories of such unclear status should not, and certainly not too easily, be used in a way that can cause the "speaker" psychological difficulties and the feeling of being lost between two families. While the danger of getting lost would be real even if specific memories were true, the uncertainty about the "truth" of the individual case makes it even more problematic.

This is why the shaykhs advise against the characteristically Druze habit of letting "speaking" produce effects in the social world through establishing relationships between the previous-life and present-life families of a "speaker". Moreover, shaykhs occasionally remind people that "speaking" does not constitute legitimate testimony in court - for instance, if a murder victim "returns" in the form of a "speaking" child - which points to the essentially unclear

and lingers on after that person has died (jinn live longer than humans). Now, it happens that the qarin of the first person after the death of that person enters and takes possession of someone else who is alive in what is called the phenomenon of mass ash-shaytān, where that qarin shifts the memories of the first person to the second person, especially if the second person is still young and has not yet reached puberty, because children are more diaphanous when it comes to external influences (jinn) and more ready to receive them - which is precisely what we can see in the majority of cases of taqammus". For this passage, see http://www.paranormalarabia. com/2008/12/blog-post_9050.html?m=1 (accessed 14 March 2017); see also http:// www.paranormalarabia.com/2011/02/blog-post_10.html (accessed 14 March 2017). In another instance, in Anīs Yahyā’s novel Jasad kāna lī, a woman who claims to have previous-life memories meets with a Christian cleric who thinks that her condition indicates demonic possession (see Yahyā 2002: 68).

38 Druze discourse at large insists that there is often sufficient "proof" to dispel doubts about a particular case. 
status of such "speaking" ${ }^{39}$ Explicitly underlining respect (ihtirām) for individual stories of "speaking", Lebanese Druze shaykh Sāmī Abī l-Munā insists that there is a difference between paving the way for a "speaking" child and silencing that child:

"regarding my opinion about this topic, as much as I respect these cases which occur often - not only in the Druze community, but in all other communities, too - there is a difference between paving the way for the child so that he or she speaks, and silencing him or her because one takes into account that this might be a case of demonic possession. ${ }^{340}$

If, according to the emic view, "speaking" just happens and little can be done about it, from that moment onwards, people do have a choice, and they have to make that choice bearing in mind that the status of the "speaking" is unclear. Like families of other confessions, Druze families are strongly advised to stop their children if they begin to "speak" about a previous life. They have to draw a clear line and thwart any attempt by another family to establish familial bonds between the two groups based on a concrete case of "speaking". Druze shaykh Sāmī Abī l-Munā recounts two cases involving members of his own family (sister; son). In both cases, people who had lost a relative showed up at the family's home and tried to make the respective child reoccupy and retake the position of their passed-away relative. Without the slightest hesitation, the shaykh insists that such visitors must be turned away - with due respect, but decidedly (shrabū finjān qahwa, Allāh maiakum, khalās, bi-kull adab wahtirām).$^{41}$ He says that his family did the appropriate thing when those visitors showed up by putting an end to the entire affair (anhaynā l-mawdīi). He could not be more explicit: stories about "speaking" may contain moral lessons ('ibar) from which people can benefit, but to really "enter" those stories and let them become "a part of our life" (șârat juz' $\bar{a}$ min hayātnā) is tantamount to entering a "gigantic maze" (matāha tawìla 'arị̀̂) ${ }^{42}$ with a real risk of getting lost and

39 On efforts to include the testimony of a "speaking" child in an Israeli court, see e.g. http://marmar.co.il/news.aspx?cid=3\&aid=5406 (accessed 9 February 2017).

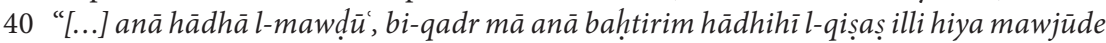
bi-kathra fì l-mujtama', mish bass fì mujtama' il-Muwahhidìn ad-Durūz, fì kill ilmujtama'āt mawjūde, fì farq bayn man yufsih fì l-majāl amām at-tifl li-yatakallam wa-bayn man yuskithu 'alā i 'tibär hädhā mass min ash-shaytān". See https://www. youtube.com/watch?v=XGN-TgQ-0iM (accessed 4 July 2017); min 49:00 ff.

41 Shaykh Sāmī Abī l-Munā; see See https://www.youtube.com/watch?v=XGN-TgQ0iM (accessed 4 July 2017); min 50:40 ff.

42 Shaykh Sāmī Abī l-Munā, see https://www.youtube.com/watch?v=XGN-TgQ-0iM (accessed 4 July 2017); min 53:00. 
ending up damaged. People should live their present life, in which they are held accountable for their acts.

\section{Conclusion}

In a remarkable parallelism, in their televised statements members of the Druze religious establishment reframe transmigration at the level of both ideas and concrete cases of "speaking". Reframing transmigration as connoted with lack of certain knowledge makes the concept not only more acceptable for a non-Druze audience but also a less clear-cut element of the Druze belief system, leaving it in abeyance. Using Qur'ānic verses to achieve this (which is hardly coincidental) keeps possibly relevant Druze texts hidden. Leaving things in abeyance also seems to be the strategy vis-à-vis the phenomenon of "speaking": reframing its origin and making room for the possibility that it does not refer to real previous-life experiences. Again, the representatives of the Druze religious establishment do this in a way that accommodates and makes use of non-Druze perspectives. Their statements on TV were made to an unspecified audience. Leaving things in abeyance not only places a protective shield around one's beliefs but also dissipates the idea that the Druze are uncritically convinced that people may remember a previous life.

Such statements by Druze shaykhs may also be directed against automatisms that spring from the all too premature certitudes of people who have taken a particular element of their belief system in their "own hands". They may be concerned that believers may cast an "inadequate" light on their belief, give that element too much weight, and in concrete cases of "speaking" do more harm than good. Finally, while for many Druze, "speaking" seems to be the phenomenon through which transmigration becomes most "palpable" ("shi $m \bar{a} d d \bar{\imath}$ malmùs"), puts the truth of their belief beyond doubt, and is intimately connected with the need to cope with unexpected loss, transmigration does not necessarily represent the core concern of the religious virtuosi.

\section{Literature}

(Anonymous) $2013 \mathrm{AD} / 1434 \mathrm{AH}$. Risāla fì ḥukm ad-Durūz wa-n-Nuṣayriyya al-'alawiyya al-musammāt: aqwāl al-a'imma al-'ālina fì ḥukm ad-Durūz wat-Tayāmina li-muftì ash-Shām al-'allāma 'Alì al-Murādì tuwuffiya 1183 AH / 1771 AD wa-ma'ahā: fatwa fì hukm ad-Durūz wa-n-Nuṣayriyya li-muftì ashShām al-'allāma 'Abdarraḥmān al-'Imādì. Dimashq and Halabūnī: Dār Bilād ash-Shām. 
Benjamin of Tudela. 1784. Travels of Rabbi Benjamin, Son of Jonah, of Tudela: Through Europe, Asia, and Africa; from the ancient kingdom of Navarre, to the frontiers of China. Faithfully translated from the original Hebrew; and enriched with a dissertation, and notes, critical, historical, and geographical: in which the true character of the author, and intention of the work, are impartially considered. By the Rev. B. Gerrans, lecturer of Saint Catherine Coleman, and second master of Queen Elizabeth's free grammarschool, Saint Olave, Southwark. [...] London: Printed for the translator, and Sold by Messrs. Robson, New Bond-street; J. Murray in Fleet-street; T. Davis, Holborn; W. Law, Ave-maria-lane, and at no. 7, Canterbury-Square, Southwark.

Benjamin of Tudela. 1840. The Itinerary of Rabbi Benjamin of Tudela. Translated and edited by A. Asher. Vol. 1-2. New York: "Hakesheth" Publishing Co.

Bennett, Anne. 1999. Reincarnation, Marriage, and Memory: Negotiating Sectarian Identity among the Druze of Syria. Dissertation, University of Arizona, USA.

De Smet, Daniel. 2007. Les Épîtres sacrées des Druzes: Rasā'il al-Hikma, vols. 1 et 2, Introduction, édition critique et traduction annotéedes traités attribués à Hamza b. 'Alī et Ismā ìl at-Tamìmì. Leuven: Peeters.

De Smet, Daniel. 2013. "La transmigration des âmes. Une notion problématique dans l'Ismaélisme d'époque fatimide," in: Mir-Kasimov, Orkhan (ed.): Unity in Diversity. Mysticism, Messianism and the Construction of Religious Authority in Islam. Leiden et al.: Brill.

Dwairy, Marwan. 2006. "The Psychological Function of Reincarnation among Druze in Israel," in: Culture, Medicine and Psychiatry 30, pp. 29-53.

Firro, Kais M. 2011. "The Druze Faith: Origin, Development and Interpretation," in: Arabica 58, pp. 76-99.

French, Christopher C. 2016. "Reincarnation Claims," in: D. Groome and R. Roberts (eds.): Parapsychology: The Science of Unusual Experience. London: Psychology Press, pp. 82-95.

Haraldsson, Erlendur and Abu Izzedin, Majd. 2002. "Development of Certainty About the Correct Deceased Person in a Case of the Reincarnation Type in Lebanon: The Case of Nazih Al-Danaf," in: Journal of Scientific Exploration 16(3), pp. 363-380.

Krawietz, Birgit. 2002. Hierarchie der Rechtsquellen im tradierten sunnitischen Islam. Berlin: Duncker \& Humblot (Schriften zur Rechtstheorie, Bd. 208).

Playfair, Gui Lion. 2007. New Clothes for Old Souls: Worldwide Evidence for Reincarnation. London: Druze Heritage Foundation. 
Stevenson, Ian and Erlendur Haraldsson. 2003. "The Similarity of Features of Reincarnation Type Cases over Many Years: A Third Study," in: Journal of Scientific Exploration 17 (2), pp. 283-289.

Talī', Amīn. 2001. At-Taqammuṣ. Aț-țab'a ath-thāniya. Buq'āta: Máriḍ ashshūf ad-dā'im li-l-kitāb.

Yaḥyā, Anīs. 2002. Jasad kāna lī. Bayrūt: Dār al-Farābī.

\section{Online sources}

https://www.youtube.com/watch?v=XGN-TgQ-0iM (accessed 4 July 2017) https://www.youtube.com/watch?v=ZgEBuxENpN0 (accessed 4 July 2017) https://www.youtube.com/watch?v=DzZbQp22R9A (accessed 3 May 2017) https://www.youtube.com/watch?v=gwyCb12-ARI (accessed 25 April 2017) www.annahar.com/article/395204 (accessed 29 November 2016) http://marmar.co.il/news.aspx?cid=3\&aid=5406 (accessed 9 February 2017)

\section{Manuscript sources}

Eberhard Karls Universität Tübingen MA VI 141 

Nour Farra Haddad

\title{
Devotions to a Druze Saint: From Philosopher to Founder Saint of the Community
}

\author{
"Each religion brought its definitions and its strata to \\ the complex history of sainthood in the Middle East" \\ (Mayeur-Jaouan 2002: 9)
}

\section{The Druze community and its sanctuaries in Lebanon: an introduction}

The Druze numbered more than one million in the early twenty-first century and are located mainly in Lebanon, Israel, Syria and Jordan, with a large diaspora (see Figs. 27 and 28). In Lebanon, they represent about $5 \%$ of the population and they are concentrated in a quite independent district in the region of Mount Lebanon, also called "Druzistan", but communities of Druze can be found close to the southern border, spread between Lebanon, Syria and Israelioccupied Palestine. They are officially recognised as one of the eighteen religious communities in Lebanon.

The Druze community continues to play an important role in the social and political life in Lebanon. They have long lived intermingled with especially the Maronite community in the Mountain area, although this coexistence was challenged by conflict several times. Of these, it is important to mention the massacres in the nineteenth century (1840-1860) and during the war period (1975-1990), especially the dark episode of the Mountain War (harb aljabal, 1982-1983). Despite all these conflicts, peaceful living together is being restored, though sensitive memories that should be healed remain. In the rural areas occupied by Christians and Druze, holy sites can be observed side by side in mixed villages like 'Abayh with its eight churches, the famous Druze maqām ${ }^{1}$ of 'Abdallā al-Tannūkhī and a khilwa. ${ }^{2}$

The cult of saints in Lebanon is very important for the Druze. They have devotions to a lot of Druze saints but also saints from different religious

1 maqām (pl. maqāmāt): "a place where we stand", a sanctuary, shrine, cenotaph, station, the burial place of a saint or prophet. Where the saint has passed or died and left a mark especially with its blessing and grace (baraka).

2 khilwa (pl. kilwāt) Druze community houses for the mashāyikh, or religious leaders. 
communities. The Druze built religious sites dedicated to biblical prophets such as Nabī Ayyūb (The Prophet Job) and Nabì Shayṭ (The Prophet Seth) and to Druze saints like Sayyid 'Abdallā al-Tannūkhī and Sitt Sāra. In the Shūf area, many shrines are established in exceptional locations, and around Mount Hermon, the Druze built holy sites on top of ancient cults which remained. Hundreds of Druze shrines in Lebanon are visited daily by the faithful and are also religious tourist attractions. Druze, Muslims and Christians practise a variety of religious rituals while visiting holy sites (lighting candles, circumambulating the darih etc.). Some of these shrines are renowned to be miraculous and attract visitors from different religious communities.

The theme of sharing shrines has recently been seriously explored by anthropologists (Albera and Couroucli 2009) and especially in the Mediterranean area by Dionigi Albera (2008). Shrines attracting joint devotions of Muslims and Jews in the Maghreb have been studied and several inventories addressed (Voinot 1948; Dermenghem 1954). Fartacek examined the shared rituals of pilgrimages in Syria (Fartacek 2012). In Lebanon, very few studies explore interfaith devotions, such as research into the shared sanctuary of Sayyīdat Bishuwāt (Aubin-Boltanski 2007, 2008).

Popular pilgrimages have spread beyond their orthodox Christian and Muslim forms in Lebanon, expressing people's piety and their need to create a relationship between their daily existence and their problems, between eternity and infinity. Muslims, Christians, Druze and occasionally even Buddhists visit the same shrines, practise the same rituals and pray to the same saints. The cult of saints and shared pilgrimages seem to have contributed to maintaining a dialogue among the faithful around shared figures of sainthood, even during some of Lebanon's most difficult moments during the war. Over the course of history, the coexistence of religious Lebanese communities has repeatedly been marked by bloody conflicts, but belief in "living together" (al-'aysh al-mushtarak) has never been lost, as Kanafani Zahar (2004) has demonstrated through her fieldwork in Hṣūn, a Lebanese village.

For the last 15 years, I have been researching the shared religious sites in Lebanon. In order to explore this theme, I conducted hundreds of participant observation hours and dozens of interviews across the entire Lebanese territory. One of the shrines explored in this research was the Druze maqaim of Nabì Bahä ad-Dīn. Attracted by its reputation, the holiness and wisdom of Nabī Bahä' ad-Dīn, many faithful from different religious communities were observed visiting the maqām and performing votive rituals.

The objective of this chapter is to introduce both the Druze saint and the shrine. I focus on the holy figure of Nabī Bahāad-Dīn and the devotions 
dedicated to him at his maqām in Shārūn, Mount Lebanon. This is the destination of a very important pilgrimage site, or "visiting" site (ziyāra), for the Druze community in Mount Lebanon.

This chapter follows an anthropological approach through participant observation and interviews conducted from 2009 to 2020. I describe the holy figure venerated, the sanctuary and the rituals practised there, to understand how the mechanisms of this place function, the motivations of the pilgrims and their relationship with the saint. In this way, I show how the principle of reincarnation is reflected by the typology of saints.

\section{Maqām Nabī Bahāad-Dīn in Shārūn-Shamlīkh, Mount Lebanon}

The shrine of Nabī Bahāad-Dīn is located in the village of Shārūn, Shamlīkh area, Mount Lebanon, not far from 'Ālayh (the capital of the district and one of the largest cities in Lebanon).

Shārūn is a mountainous village of Mount Lebanon, one of the largest of the 'Ālayh district, located $31 \mathrm{~km}$ from Beirut at 1,100 m above sea level. During the winter period, snow can block access to the village. The name of the village derives from the Aramaic language, meaning "the agricultural hills". The large majority of its inhabitants are from the Druze community. It is a rural community living mainly from small businesses and agriculture.

On the way to maqām Nabī Bahăad-Dīn, just before reaching the locality of Shamlīkh, in Shārūn, on the main road, a renowned maqām dedicated to Sitt Sāra can be found. Local traditions report that a Druze saint, Sitt Sāra, rested on this stone on her way to maqām Nabī Bahāad-Dīn.

Sitt Sāra is an important woman in Druze history, the niece of one of the authors of the "Epistles of Wisdom" (Rasä'il al-hikma), Imam Bahāad-Dīn alTa'i al-Samūqī, also known as al-Muqtanā Bahāad-Dīn or "al-Muqtani”. The maqām of Sitt Sāra is a very small shrine, 7 by 4 m, consisting of a single room with a cupola with the multicoloured Druze star on top. Inside the shrine there is no tomb, but a big stone slab surrounded by an iron grille. Tradition states that the saint rested on this stone while passing by the village, and from then on it has been full of blessing and grace (baraka). All of the walls of the maqām are covered with velvet carpets offered as ex-votos, with a wide range of animal, natural, social and religious themes, such as lions or deer (the offerings are seen at maqām Nabī Bahāad-Dīn). A small mihrāb is also visible inside the room. Devotees take baraka by touching the sacred stone and praying around it. At the entrance of the shrine is a special stand for lighting candles. 
Maqām Nabī Bahāad-Dīn is located at the edge of the village, overlooking the valley from a limestone cliff. This shrine is also named as "noble", after Saint Luke or after the locality: maqām ash-Sharīf, maqām an-Nabī Lūkā or maqām Shamlikh. It is among the most important Druze places of worship in Lebanon.

The oral tradition retraced the construction of maqām Nabī Bahāad-Dīn to the eleventh century (1017 CE or $408 \mathrm{AH}$ probably being the date on which al-Hākim bi-amr Allāh appointed him governor of Damascus). It was set up within one of the khilwa of the region. Over the centuries, it underwent several restorations and the current structure dates from the twentieth century. The room that houses the darih, ${ }^{3}$ the presumed tomb of the saint, with its arches, supposedly dates from the medieval period, but nothing can really attest to that.

It is a place of worship called maqām not because Nabī Bahāad-Dīn was buried there but because he would have rested on a stone there. The darih would not house the body of the saint. The Druze do not believe that the saint is buried in this place but somewhere in the Himalayas; however many faithful, from different communities but mainly Druze, are convinced that the saint is buried at maqām Nabī Bahāad-Dīn. Several shrines and places of visitation in the region are dedicated to Nabī Bahāad-Dīn, with darịh like that in the Palestinian city of Bayt Jann, now occupied by Israel.

At the entrance of the Lebanese shrine to Nabī Bahäad-Dīn, a fountain offers water to the pilgrims, which is known to be full of graces. Upon entering the shrine, you get to a large esplanade surrounded by arches. All the rooms in the shrine are organised around this courtyard (Fig. 14).

The room containing the darih is located on the left side of the sanctuary. It is the major holy room of the shrine that all faithful visit, first removing their shoes. Half of the walls are covered with velvet carpets offered as ex-votos, with a wide range of animal, natural, social and religious themes, such as lions and deer (as in the maqām of Sitt Sara), bullfights and Jesus Christ preaching (Fig. 15). The dari h, located at the entrance of the big arched hall on the left, is at the heart of the devotional practices; the faithful touch or kiss it and pray around it (Fig. 16). The dari hi is covered with the multicoloured flag of the Druze.

Other rooms in the shrine serve as a house for the shaykhs and their families taking care of the sanctuary, and some are used to host pilgrims who want to sleep over to perform the incubation ritual (laylat al-istikhāra, described below).

3 The darih is the tomb or cenotaph of the saint; in some cases it is only symbolic and indicative of a sacred presence. 
Three families are responsible for managing the maqam: The Sayegh, the Ahmadiyya and the Banna. At present, Shaykh al-Banna mainly manages the sanctuary. Outside the summer season, it receives about ten visitors on weekdays and a few dozen at the weekend. In spring and summer, the number increases to hundreds of worshippers a day especially during the weekends.

The sanctuary opens its doors 24 hours a day to pilgrims. Sometimes the faithful visit the shrine by night. The shaykh states, however, that in winter they close the doors around midnight as a safety measure. The motivations of the faithful for coming to this maqām are diverse, but the large majority wish to make votive offerings.

A religious, social and cultural mix thus characterises the visitors to this holy place who mingle in an atmosphere conducive to graces and miracles. The rector of the sanctuary talks about dozens of miracles attributed to Nabi Bahäad-Dīn, including the healing of children, healing cancer and the gift of children to infertile women.

The site is easily accessible, with a large parking area at the entrance, and it is very well maintained. The location of the shrine is unique, overlooking the valley from the cliff and inspiring peace and holiness. Visitors receive a friendly welcome from the shaykhs. Faithful Druze report miracles attributed to the saint which are efficacious toward all religious communities.

The Ministry of Tourism and various religious institutions seek to develop religious tourism through different initiatives. 2018 was officially declared the Year of Religious Tourism in Lebanon by both the Ministry of Tourism and the Ministry of Foreign Affairs. On the official website of the former Ministry, a section is devoted to religious tourism, including a short description of maqām Nabī Bahäad-Dīn. On the official website ${ }^{4}$ of the Druze community, there is a space on the maqāmant but it is not yet developed. We see only a few pictures of Druze shrines.

Thus maqām Nabī Bahāad-Dīn has all characteristics required to place it on the map of religious tourism in Lebanon but for now the Druze committee managing Druze religious sites in Lebanon do not want to encourage tourism. Visitors are largely limited to pilgrims.

\section{Nabī Bahāad-Dīn: A pillar and founder of the Druze religion}

Historically, the Druze faith made its appearance in the eleventh century in Fatimid Egypt under the reign of al-Hākim (996-1021 CE), who is said to be

4 See http://mouwahidoundruze.gov.lb/makamat/1 (accessed 30 June 2020). 
the manifestation of Allāh on Earth. This religion probably owes its name to Muhammad al-Darazīi, a disciple of al-Hākim, but members of this community do not like this name, considering this disciple to be a dissident. They prefer to be called muslimin al-mūwahhidīn.

Hamza ibn 'Alī was responsible for the diffusion of the Druze religion, aided by his contemporaries, Bahāad-Dīn al-Muqtanā and Ismāîl ibn Muhammad at-Tamimin. They defined the doctrinal corpus of the new religion. The main scriptural reference for the Druze is the Epistles of Wisdom, which includes texts written by Hamza and al-Muqtanā.

The sanctuary referred to here is dedicated to this founding character and prime diffuser of the Druze religion. We can retrace the course of the life of Imam Bahāad-Dīn al-Ta'i as-Samūqī, renowned as al-Mūqtani or al-Muqtanā, born in the locality of Samoka, close to Aleppo, in $980 \mathrm{CE}$ (370 AH). In 1015 $\mathrm{CE}$, he was assigned as the governor of Aphamea near Aleppo. Two years later, al-Ḥakim bi-amr Allāh named him the governor of Damascus. (Abu Ghanem 2003: 1.) He therefore counts among the famous Druze who spread "the call" or "appeal" (da'wa) during the Fatimid period. In $1021 \mathrm{CE}$, he was appointed as the head of the community to succeed Hamza, who mysteriously vanished leaving hope for his messianic return.

Known for his knowledge, wisdom, piety and asceticism in a period of trouble and insecurity, Nabī Bahāad-Dīn wrote several letters which are part of the Epistles of Wisdom to different leaders of various religious communities, explaining that the Druze respect all the prophets and holy men of various affiliations. These letters were sent with missionaries through Syria, Palestine, Iraq, Persia and India, preaching "divine unity" (tawhìd). He was persecuted for following Hamza ibn 'Alī; at-Tawhìdī and many of his followers and emissaries were also persecuted until the caliphate passed from al-Hākim bi-amr Allāh to al-Z̄āhir, who increased persecution of the tawhidiyyin and pushed to declare the closing of the "call" (Abu Ghanem 2003). Since 1034 CE, proselytising has been banned in the Druze faith. You are born Druze, but cannot become Druze: the community closed its doors to new members. That year Nabī Bahäad-Dīn fled persecution, leaving Cairo for an unknown destination. Some sources explain that he may have been of Christian origin as his writings reveal unusual familiarity with the New Testament and Christian liturgy (Hitti 2007).

This saint is therefore very important to the Druze and is considered to be a founding member of the community. Even if we do not have any iconographic or biographical representations of this character, many testimonies and references attest to his real existence and trace his hagiography. With an Ismaili Imam from Khorasan, he defined the doctrinal corpus of the new religion. 
It is said that he completed the writing of parts of the sacred Druze books. He has received several nicknames, the best known of which is al-Muqtanā, but also the "Left Eagle" or "left wing" (al-janāh al-yasār), the "tongue of the Believers" (lisān al-mümininn) and "The Pillar of the Unitarians" (as-sanad almüwahhidinn). All these nicknames testify to his importance for the community. Several explanations are given regarding the symbolism of the colours of the flag and Druze star. One interpretation is that the five colours evoke the five pillars or founding members of the allied community and their virtues.

At the time of al-Hākim, the intelligence associated with green manifested itself in Hamza; the soul associated with red was expressed in his son-in-law, Ismāîl at-Tamimī; the "word" (logos) associated with the yellow goes with Abū 'Abdallah al- Qurashī; the precedent associated with blue in Abù al-khayr asSammuri; and the antecedent associated with white in Bahäad-Dīn al-Muqtanā.

It is particularly interesting to note that this maqām is also known in several references and by locals as the maqām of Nabì Lùkā (Saint Luke). When I asked the two shaykhs managing the sanctuary about this issue and interviewed many faithful, I discovered an amazing story about the history of the saint and his several reincarnations. It was surprising to learn that for the Druze, Nabi Bahāad-Dīn is the reincarnation of Plotinus, "Aflātūn", himself reincarnated in Saint Luke (Nabī Lūkā) and then in Nabī Bahāad-Dīn. ${ }^{5}$

From this statement, two constants of the Druze religion emerge: the belief in reincarnation (taqammuss) and the recognition of holiness and wisdom in various religions throughout the world and time. Influenced by various currents including Zoroastrian thought from Persia, the Druze have adopted the belief in reincarnation. A Druze does not die; he or she transmigrates. There is also a belief that points to the direction of each person's journey (maslak), an idea that we will not have space to develop here. Souls pass from one body to another in successive transmigrations aiming at perfection. The wisdom inherited is enriching with time. Slowly, souls migrate towards the divine.

The clear designation of two important characters in Antiquity and ancient Christian wisdom is also very significant. Officially named the "religion of the divine unity" (din at-tawhìd), the Druze faith is a synthesis of various religious

5 Despite the terminological difference between Aflūṭin (actually Plotinus), and Aflātūn (Plato), the local religious sheikh I interviewed specified that by Aflāṭūn, he meant Plotinus and not Plato. While that confusion may exist, what seems important to the faithful is the figure of a prominent Greek philosopher itself, regardless of the terminological imprecision. 
and intellectual currents. The Druze doctrine takes root in a synthesis of the three monotheisms with ideas stemming from the Manicheism, ancient Egypt, India and the Greek world. It contains elements of both Muslim mysticism and Koranic thought, but also of Persian and Indian religions, Neoplatonism, Gnosticism and Messianism.

The Druze doctrine sought a synthesis between Oriental thought, Greek philosophy and the three monotheisms. It is strongly influenced by Sufism, which advocates moving away from earthly concerns to better approach God.

On the one hand, we have therefore Plotinus, a Greco-Roman philosopher of late Antiquity, principal representative of the philosophical current called Neoplatonism. He believed that all truths were contained in Plato's philosophy, both his oral dialogues and his unwritten teachings. Plotinus combined reason and spirituality, mysticism and philosophy, contemplation and action in order to create an understanding of reality (metaphysics) and way of life that would deeply influence later developments in Christian, Jewish and Islamic theology and mysticism. Plotinus' understanding of the world as existing in fundamental unity, his belief in a "One" beyond words and the soul's path to enlightenment, share similarities with the Druze faith. The Druze perfectly integrate the philosophy of Plotinus (third century CE) and the Plato school (El Halabi 2006: 44). For Plotinus, the One is the source of life and everything, the One transcends the world as this perfect unity. It is a perfect thing without any limitations. It is so unlimited that it cannot even be described: this is known as negative theology.

Like both Plato and Pythagoras (another important reference for the Druze), Plotinus believed in reincarnation. People remain in this cycle of reincarnation until they unite with the One.

In his treatise on the Druze faith, Sami Makarem (1979) equally emphasizes the appeal that greek philosophers had in the eleventh century, including Aristotle's teachings and Platon's understanding of God. Besides the apparent importance of Abrahamic religions for the Druze faith, he also notes the limited influence of Hinduism and Buddhism.

The philosophy of Plotinus deeply influenced some Islamic philosophers and Sufi as well as important Christian thinkers such as Augustine and Aquinas. Greek philosophers occupy a privileged place in Druze writings and beliefs. Plotinus specifically is very important for the Druze who refer to him on their official website ${ }^{6}$ and consider him a saint, very clearly speaking of his endurance

6 See http://mouwahidoundruze.gov.lb/makamat/1 (accessed 30 June 2020). 
and elaborating on his wisdom. He is a renowned source of wisdom in Lebanese culture in general. Many popular quotes in Lebanon, reported by people from different religious communities, mention Plotinus (Aflạtūn) as a very wise person, such as "he thinks he is Aflātūn!" (mufakkir ḥālo Aflātūn).

The same shrine is named after Saint Luke - maqām an-Nabī Lūkā. Even if there is no bibliographical reference or even official oral tradition associating Nabī Bahäad-Dīn to Saint Luke, for locals and shaykhs there is no possible doubt that Nabī Bahāad-Dīn is indeed the reincarnation of Saint Luke.

Saint Luke the Evangelist is an apostle of Paul and probably never met Jesus Christ during his life on earth (even if some traditions hold that he was one of his twelve apostles). He is one of the four evangelists, considered to be the author of the third Gospel and Acts of the Apostles and an artist (famous icons of the Virgin Mary are attributed to him). Saint Luke contributed over a quarter of the text of the New Testament, more than any other author. Many scholars believe that Luke was a Greek physician who lived in the Greek city of Antioch in Ancient Syria, a part of modern-day Turkey. He was one of the first converts to Christianity and he accompanied Saint Paul on his missionary journeys, travelling a lot. He stayed with Saint Paul in Rome when he was in prison awaiting death. We hear no more of him afterwards and what he did in his last years is unclear. According to Saint Jerome, Saint Luke died in Achaia (Greece) at the age of 84 , and it is unknown whether or not he died a martyr's death. In any case, the church venerates him as a martyr, and the anniversary of his martyrdom is 18 October. As the patron saint of doctors and artists, he occupies a central place in Christianity. Druze recognise and value his knowledge and wisdom as they do for many other Christian prophets and saints. They venerate him as being an educated physician in the Greek-speaking city, a renowned historian, an artist and among the most cultured and cosmopolitan members of the early church.

The devotion to Nabī Bahäad-Dīn, recognised as the reincarnation of two notable holy figures of Antiquity and early Christianity, attests to the Druze recognition of holiness and wisdom in various traditions throughout the world and time. 


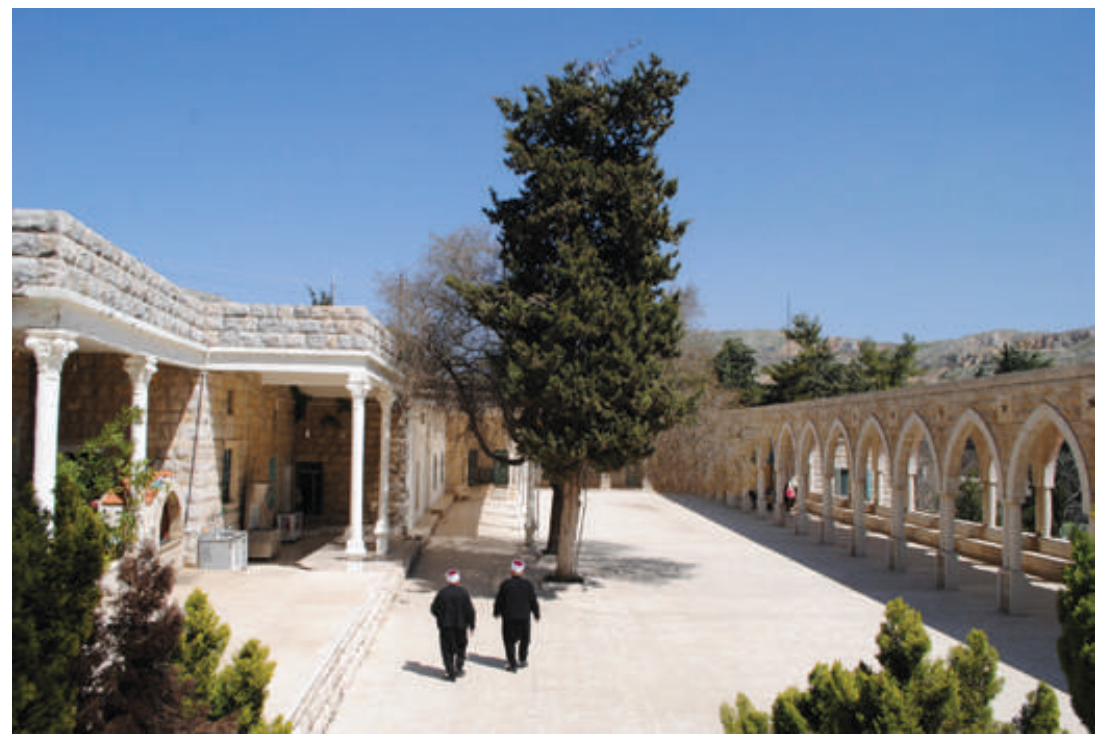

Fig. 14: The external court of the Nabī Bahāad-Dīn pilgrimage site. The burial room is located in the building on the left. Photo: Nour Farra Haddad, 2014.

\section{Visits and rituals at maqām Nabī Bahāad-Dīn: A Druze saint full of baraka}

Pilgrims visit this holy place individually or in small groups for devotional and votive visits (ziyārāt). The saint has no special feast and no collective gathering planned annually on fixed dates. Collective and festive gatherings can be arranged exceptionally.

Since its establishment, the maqām is therefore the subject of ziyārāt, renowned for the miraculous force of blessing (baraka) sent by the divine presence sometimes through the vehicle of saints, to human beings. For Fartacek, the transmission of baraka is at the heart of shared ritual actions performed in the context of vows in Syria (Fartacek 2012: 122-124). The pilgrims make ziyārāt in order to receive baraka, make vows or fulfil them.

Locals and shaykhs informed us that pilgrims from different religious communities and backgrounds come to visit and obtain all kinds of blessings and graces. The pilgrims to the shrine are mainly Druze from all the Lebanese regions, some Druze from other countries but also a few Christians from Mount 
Lebanon who came to make vows to the saint. The shaykhs recognise indeed the rare visits of some Christians to maqām Nabī Bahäad-Dīn.

The saint does not seem to have a specific patronage but responds to all kinds of demands ranging from healings, to success, to protection, to women in need of children. The votive rituals have been practised for centuries until today. The same rituals are practised by Christians and Muslims: the rites of incubation, sacrifice and offerings.

Maqām Nabī Bahāad-Dīn proposes a series of prayer initiatives and devotional practices to the faithful. Rites are classified in order of importance by the pilgrims depending on their potential efficacy. Several rituals may overlap or can be organised to make up a single votive approach within a single pilgrimage. During pilgrimages, pilgrims organise a whole series of rites according to recommendations or intuition (including devotional practices, contemplation and prayers). Little gestures and attitudes play a role in the final organisation of the actions. The devotional practices performed in search of baraka in the context of the sanctuary revolve mainly around the dari h. The pilgrims kiss, touch and circle around it, and tie tissues or threads on it.

The rite of circumambulation (tawäf) around the darih is very common. By moving in a circle the faithful imitates the path of the sun and the planets and pays homage to the cosmic forces. Pilgrims generally turn three or seven times anticlockwise around the dari $h$ while formulating their vows and reciting prayers. They reproduce the Mekka tawäf.

The offerings at the sanctuary are of a different kind. They can be material, such as foodstuffs, handicrafts, chandeliers and particularly carpets. Shaykh Suhayl even told us that a year ago a Druze woman from Qatar noticed water damage at the shrine and then offered to pay for its $250 \mathrm{~m}^{2}$ roof to be repaired. Icons of Saint George are prominent among the offerings, testifying to the great devotion of the Druze to this saint. In many Druze maqāmāt, we find icons and images of Saint George; devotion to him is shared by most of the religious communities in Lebanon.

What makes this sanctuary (along with the one of Sitt Sāra) very original is the velvet carpets that cover a large part of the walls. This kind of offering seems to have been fashionable from the 1950s to the 2010s. It is very interesting to analyse the themes of the carpets, which are very significant for Druze philosophy, bearing references to traditions from around the world, both cultural, such as bullfighting in Spain, and religious, such as episodes from the life of Jesus Christ. Nowadays, the faithful can no longer find this kind of carpet, and it seems that the tradition of covering the walls of the shrine with these carpets has stopped. Half of the arched walls of the darih room are still empty. The 
ex-votos that remain on the darih are also of different types ranging from hair ties, to amulets, to pieces of fabric.

The purchase and making of amulets is also a common practice at the shrine. The Druze call these amulets hirz; Muslims call them hijāb and Christians dkhira. The hirz are sold by the shaykh and by a lady who installs a table at the door of the maqām during the summer season. Those who are sold by the shaykh are made by his wife, the shaykha, who inserts verses from the Koran and sometimes from the elements of the sanctuary like a soil or oil on a tissue. For an extra 5,000 Lebanese pounds she can customise the hirz mentioning a specific name inside it. These amulets protect the wearer from evil eye and guarantee baraka, giving graces to those who wear them. The hirz for men and women are the same but they differ for children.

For sacrifices there is a slaughterhouse (maslakh) on site, managed by its shaykhs, as we can still find in different Shiite and Druze sanctuaries. The pilgrims may choose to leave all or part of the sacrifice at the sanctuary, to offer it to the poor or keep portions for a festive meal at home. Unlike other holy places, this maqām does not provide the faithful with a place to have a meal at the shrine. But several popular picnic areas nearby are used by the faithful. The shaykh in charge of the shrine informed us that sacrifices are less and less practised, especially for reasons of hygiene.

The rite of incubation (laylat al-istikhära) is still practised within the sanctuary. For the last ten years the shaykh has decided to limit the rite to one night. We collected testimonies from the faithful who testified that they spent several nights in this holy place. Rooms with mattresses are available for them around and under the main courtyard of the sanctuary. The main objective of this rite is to soak up the baraka of the place and the saint. The date of this night is chosen carefully; for instance a woman in need of a child can plan to spend a night in the sanctuary before planning a sexual relationship with her husband.

Many books about the Druze state that you will never be able to see a Druze performing a rite due to their practice of "concealment" (taqiya). However, when votive devotional practices are shared by different communities this is not the case at all. The Druze practise votive rituals without concealing them. The baraka which all seek is mainly linked to the darih of the saint, even if the shaykhs and some pilgrims seem to be aware that the saint is not in fact buried here. 


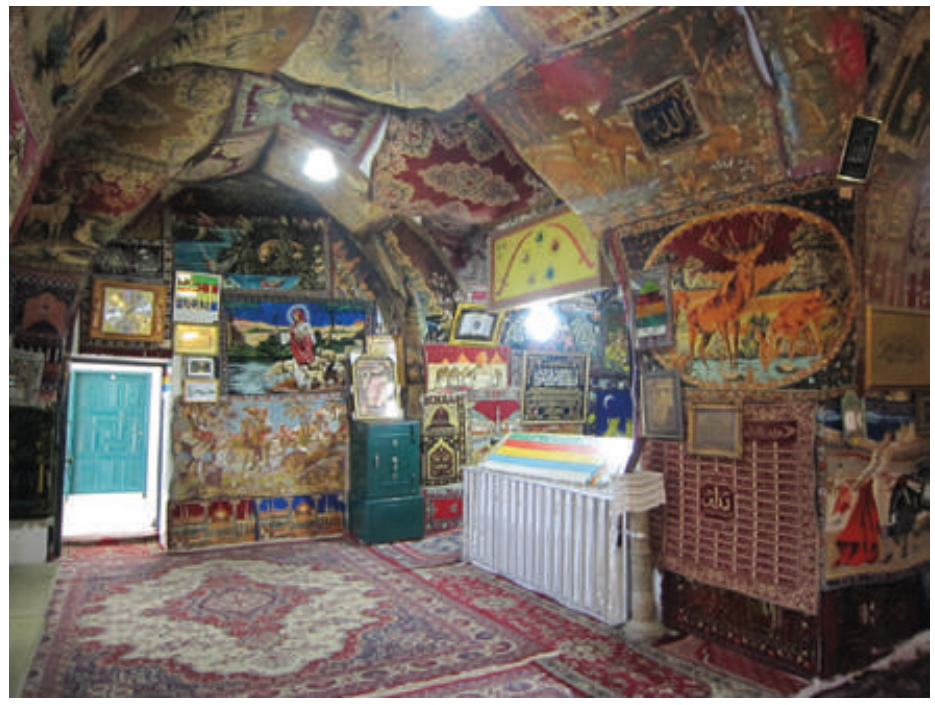

Fig. 15: The tomb (darīh) of Nabī Bahäad-Dīn inside the maqām. The walls of the maqām Nabī Bahāad-Dīn are covered with carpets of different motives featuring animal themes. Photo: Nour Farra Haddad, 2014.

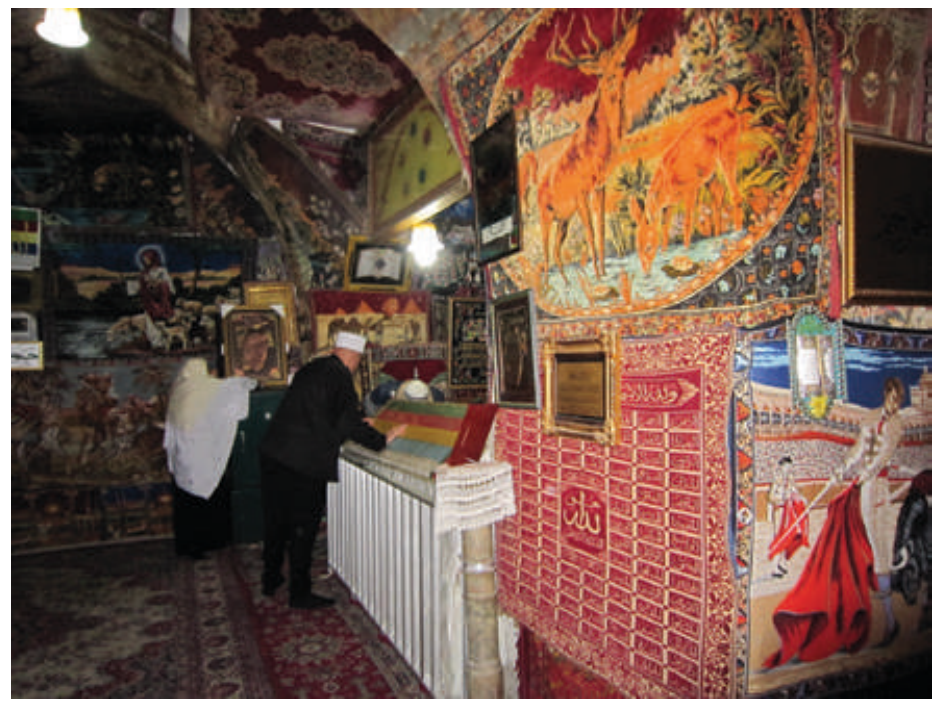

Fig. 16: Receiving baraka at the tomb of Nabī Bahäad-Dīn. Photo: Nour Farra Haddad, 2014. 


\section{Universal wisdom, timeless holiness, shared devotions and rituals in search of baraka}

The strong belief in reincarnation among the Druze creates a feeling of kinship, cements social relationships between people and creates equality within the community. This reincarnation also applies to saints through the ages. The Druze have devotions to saints and "wise ones" ('uqqāl) going back to Antiquity, from all around the world and from different religious communities. Shaykhs and Druze 'uqqāl sometimes travel to visit shrines around the world to get inspiration from universal holiness and wisdom, believing that the truth can be equally revealed in the Himalayas, the mountains of Scotland or the Andes (Callebaut 2000: 83).

The faithful's devotion to Nabī Bahāad-Dīn demonstrates how each religion has brought its strata of holiness and above all wisdom in the complex history of the construction of Druze wisdom. In one holy character we can understand layers of sacredness that should lead to the One, to the truth. This cult helps us to better understand the Druze faith and its foundations, the construction of holiness within this community and the significant degree of porousness within and between religions throughout the ages.

Unlike the Druze who are "initiated" (mashāyikh), the "ordinary" members of the Druze community do not have physical access to a holy place that would be the equivalent of the church or mosque to pray and worship. The khilwa is reserved only to the initiated Druze and religious dignitaries. For that reason, the uninitiated Druze are attracted by maqām (or mazār) where they are able to express their faith, practise devotional and votive rituals and pray, showing their devotion to a saint. (Kassatly 2016: 223; Callebaut 2000: 31.) A ziyāra is a pilgrimage to a sacred place that leads to an encounter with a saint, experienced through a series of rituals and devotional practices. A ziyāra is a visit to the saint, șăhib al-maqām (or al-mazār). The pilgrims hope that the saint will listen to their problems and their requests. They address the saints as confidants believing that they understand their difficulties. Regardless of religious background, all people seek divine assistance for health problems, infertility or other issues. The reasons for visits to shrines are universal and can transcend religious differences all over the world.

Devotional rituals observed at maqām Nabī Bahāad-Dīn and other Druze religious sites testify to the practices in Lebanon shared by all faithful seeking baraka. The same rituals are practised at Christian and Muslim sites. Faithful visit the shrines for the same reasons. A universal spirituality is observed, just as in the frame of the Druze wisdom. 
Most of the shared sanctuaries in Lebanon have very long histories that date back to pre-Christian and pre-Islamic times and many rituals are inherited from Antiquity. The faithful believe that the power of baraka can increase with time, especially when it is transmitted from one holy person to another through generations.

Maqam Nabī Bahāad-Dīn is a site of encounter with holiness from different civilisations and periods. The faithful are spiritually enriched by this encounter with the saint and acknowledge, even if they are not initiated, the Druze's universal religious beliefs. Such an encounter can also lead to an interfaith dialogue between different religious communities in Lebanon.

\section{Literature}

Abu Ghanem, Shafic. 2003. Religious places frequented by the Mou'wa'he'doon. Druze (Ma'ka'mat): http://www.mmouka.com/uploads/ ReligiousMakamatToVisitEng.pdf (accessed 12 January 2018).

Albera, Dionigi. 2008. Why Are You Mixing What Cannot Be Mixed? Shared Devotions in the Monotheisms. In: History and Anthropology, Vol. 19, No. 1, March: 37-59.

Albera, Dionigi and Maria Couroucli (Dir.). 2009. Religions traversées: lieux saints partagés entre chrétiens, musulmans et juifs en Méditerranée. Arles: Actes Sud.

Aubin-Boltanski, Emma. 2007. Miracles et apparitions de la Vierge au Liban : La preuve par l'Autre. Séminaire Anthropologie des dispositifs cultuels, shadycgspm/ehess, Marseille, may.

Aubin-Boltanski, Emma. 2008. La Vierge, les chrétiens, les musulmans et la nation. Terrain, No 51, septembre : 10-29.

Callebaut, Paul Jacques. 2000. Les mystérieux Druzes du Mont-Liban. Bruxxelles: La Renaissance du livre.

Dermenghem, Emile. 1954. Le culte des saints dans l'islam maghrébin. Paris: Gallimard.

El Halabi, Abbas. 2006. Les Druzes, Vivre avec l'avenir. Beirut: Dar El Nahar.

Fartacek, Gebhard. 2012. Rethinking Ethnic Boundaries: Rituals of Pilgrimage and the Construction of Holy Places in Syria. In: Kiliánová, G. A., Jahoda, C. A. and Ferencová, M. (eds.): Ritual, Conflict and Consensus: Case Studies from Asia and Europe. Vienna: OeAW-Verlag, 119-130.

Hitti, Philip. 2007. The Origins of the Druze People and Religion. New York: BiblioBazaar. 
Kanafani Zahar, Aida. 2004. Liban : le vivre ensemble, Hsoun, 1994-2000. Paris: Geuthner.

Kassatly, Houda. 2016. Travestissement et sainteté: la figure druze de Sitt She'waneh. In : Figures de sainteté féminine, musulmane et chrétienne en Afrique du Nord et au Proche Orient, Actes du colloque international, CEDIFR. Beirut: Presses de l'USJ.

Makarem, Sami. 1979. The Druze Faith. New York: Caravan Books.

Mayeur-Jaouen, Catherine (Dir.). 2002. Saints et héros du Moyen-Orient contemporain. Paris: Maisonneuve et Larose.

Voinot, Louis 1948. Pèlerinages Judéo-Musulmans du Maroc. Paris. Larose.

\section{Internet sources}

http://www.mouwahidoundruze.gov.lb (accessed 12 November 2017)

http://www.destinationlebanon.gov.lb/en/tourismtype/details/11/29 (accessed 19 April 2015)

http://thecenteroflove5.blogspot.com/p/druze-and-their-sacred-places.html (accessed 19 April 2015)

http://www.mmouka.com/uploads/ReligiousMakamatToVisitEng.pdf (accessed 19 April 2015)

http://www.sacred-texts.com/asia/odpr/odpr09.htm (accessed 12 November 2017) 
Salma Samaha

\section{Landscape Imprint of Mortuary Dwellings in Different Sociocultural Context: A Comparison of Christian and Druze Funerary Practices in Lebanon and Syria}

\section{Conceptions of death imprint distinctively on landscape: Some preliminary remarks}

Death is as natural a phenomenon as birth but at the same time an absolute strangeness. Death represents a fear that every human being feels in a more or less consistent way. Religions have a common bond with death since they are concerned with eternal life. "Religion has the potential either to increase or to decrease anxiety, depending on various sociocultural, situational or individual factors" (Pressman et al. 1992: 99).

In the concepts of both resurrection and reincarnation, the dead "survive" by the separation of the soul and the body; souls live again when the physical body disintegrates. Although eternal life is a gift from God, some consider that resurrection, not the immortality of the soul, is the essential theme of Christianity and Islam. Others perceive this "survival" of the dead on the basis of their belief in reincarnation. According to this doctrine, on the death of the physical body, the "spirit" leaves the latter to be reborn and live in another body, which would allow an individual to continue their life experiences and spiritual and moral evolution. For the Druze community, reincarnation is one of the fundamental facts of faith.

"The landscape means an area, as perceived by people, whose character is the result of the action and interaction of natural and/or human factors" (European Landscape Convention 2000). Human societies relate to death by engaging many systems of values and beliefs as a set of rites, symbols, practices and traditions that place human confrontation with death in an eminently religious perspective. If religion appears as the main response of the living to death, the form that this response takes can be more or less intense, depending on the culture. From this perspective, the placement of a burial area or a grave is the result of past and present choices made by individuals of a certain society in relation to the landscape they live in (Kackwitz and Lindholm 2013: 146). Funeral rites are intended not only to regulate the fate of the corpse but also to 
support the survivors through specific ritual codification and regulation. Thus, "funerary rites are rites of separation that allow one to detach oneself from the dead" (Lenoir and De Tonnac 2004: 25), by the establishment of a memory that detaches the person from their remains, so that this person can find a place in the imagination of the living. Funerals and collective mourning also enable special moments of sociability that mark the history of a group.

People choose different landscapes for death: some systematically refuse to provide a final resting place for the body in the ground, though this does not always correspond to the absence of the cult of the dead. Since ancient times and up to the present, many people were convinced that without burial, the soul is unhappy; death was less feared than deprivation of a tomb. Tombs were dwellings given the most visible landscape mark of life - habitation. Instead of "destroying" their dead, the living housed them, in ways as varied as their own homes.

"The cult of the dead serves to institutionalise the space" (Claval 2003: 126). It is inscribed in the landscape in the ways in which people reflect on the major enigmas of their lives and treat their dead, whose lives they imagine in the afterlife. Even though cremation has been legal in many countries since the early twentieth century, when several parliaments passed cremation acts, "the burial of bodies remains the norm" (Dubois 2005: 93). The diversity of mortuary dwellings depends essentially on conceptions of life and the afterlife. Indeed, physical and technical conditions have an extremely low influence. The cremation map has no relation to the distribution and thickness of soils. Although sometimes a specific geographical position determines the choice of resting place for the dead, "mental representations of the afterlife are often populated by geographical references. Religions often promote geographical representations of the lands of the dead based on landscape realities that can be analysed through the prism of the real landscape. These are since they are" (Dubois 2005: 67).

In Lebanon, the physical landscape played an important role in forming religious communities. Two-thirds of the country is mountainous, with a rich ecology and abundant water resources. This harsh configuration was favourable for fortification and defence and historically served as a refuge for nonconformists and banished people.

Lebanon was founded by sailors who settled on the coastline and groups of refugees isolated in the mountains far from the invaders' reach. The earlier presence of Lebanese religious communities compared to the emergence of a political entity in the sixteenth century often leads to confusion about the history of religious communities and Lebanon as an entity (Corm 2005). Since 
religion is deeply rooted in geographical space, the marks in the landscape made by the religious communities are considered as spatial identifiers, more or less easily recognisable (Dubois 2005).

Thus, currently Lebanon is a religious mixture. In all, there are eighteen possibilities for a Lebanese person to practise his or her belief as a Christian, Muslim or Jew, since every Lebanese person is a member of their own community of birth or later of choice.

\section{Case studies: A comparison of the mortuary dwellings in Shūf mountain (Lebanon) and Suwaydā' (Syria)}

\section{Profiling the sites}

Shūf mountain (Jabal ash-Shūf) is the southernmost part of the Mount Lebanon range, a religiously diverse region hosting predominantly Druze and Christian communities, mainly Maronite. It is located about $40 \mathrm{~km}$ southeast of Beirut. It is bordered to the north by the governorate 'Ālayh, to the south by the governorate South Lebanon, to the west the Mediterranean Sea and extends eastwards to the Biqā district limits, marked by the mountain Barouk (Jabal al-Bārūk), famous for its cedars and hills leading down to the sea. For Shüf Mountain, I only consider districts excluding its coastal plain, because of the absence of the Druze community from the coast. Here, I focus on the area of midsized slopes on which most villages and small towns are located. In the north and south, hills and valleys separate the villages from those of neighbouring districts, 'Ālayh and Jizzìn. The southeast zone of 'Iqlīm al-Kharrūb has been excluded because of the presence of the Sunni community, thus highlighting the Druzo-Christian religious difference. The villages of Shüf mountain are distributed in the Shūf al-A'lā regions in the extreme southeast of the district, Shūf Suwayjānī below, Harf in the far north and in the centre. The administrative centre is Bayt adDin, Mount Lebanon residence of the emirs and now the historical core of the Lebanese Republic in political and geographical terms. The study area includes, 54 villages of which 18 are Christian, 13 Druze and 23 mixed.

This study was conducted between 2006 and 2009 as part of my $\mathrm{PhD}$ in Culture and Territory at the University of Rome Tor Vergata (Samaha 2010).

Knowing that our field of research includes Christian and Druze communities, we are confronted with two different visions of the world, of existence and therefore of death: the resurrection for Christians and reincarnation for the Druze. Since there is a considerable gap between these two beliefs, it would be interesting to see the landscape imprint of the dwellings respectively reserved 
by these two religious communities for their dead. To do this, I conduct a landscape analysis according to the triple method developed by Frédérique Tanguy (poetic, visual and cognitive) that accounts for the identity of each landscape entity (Tanguy 1995).

The main difficulties were the unavailability of bibliographic information about Druze mortuary dwellings and conducting the field survey. Concerning the field survey, it was often necessary to ask for information for the exact location of cemeteries, which aroused the most diverse reactions and even suspicion, constraining us to have a Druze guide. To overcome the absence of bibliographical references to the topic, it was necessary to broaden the study area to the Druze regions in Syria. These are located in Jabal ad-Drūz in the governorate Suwaydā', the southernmost of Syria's governorates. Since its inhabitants are predominantly Druze, it can be considered as a baseline for defining the influence of their interaction with Christian communities.

\section{The landscape distinction of burial elements: Identical representation of death for different conceptions of belief}

In the Shüf mountains, we can isolate three groups of cemeteries, according to their status: cemeteries of exceptional character for war martyrs or dynastic lineages (Fig. 17); private cemeteries, reserved mainly for sheikhs and some who had the honour of being buried in places of worship (Fig. 18); "public" cemeteries. It is the landscape impact of these that interests us here, particularly the visible, therefore the spatial dimension assigned to death regardless of the spiritual dwelling.

It is truly astonishing to notice the similarities in representation of the burial space adopted by the Christian and Druze communities, despite their diverse conceptions of life and death (resurrection and reincarnation). In all Shūf mountain villages, whether they are exclusively Christian, Druze or mixed, the tomb has ceased to be individual, at the except for martyrs, to be replaced by a kind of room, with a maximum dimension of 4 by $4 \mathrm{~m}$ and an average height of $2.5 \mathrm{~m}$, serving as a burial chamber (Fig. 20). A metal door hermetically seals this room with a square opening, on average $1 \mathrm{~m} \mathrm{high}$. It is thus a kind of overground family vault, a multi-level funerary in which the coffins are superimposed, enabling quick replacement. The only notable difference between the two burials is the presence of the cross for Christians and various symbols and words for the Druze: the Druze star, the crescent, the inscription of the word Allāh, or more frequently the expression Allāh haqq, "God is right" or al-mawt haqq, "Death is right" (Fig. 19). 


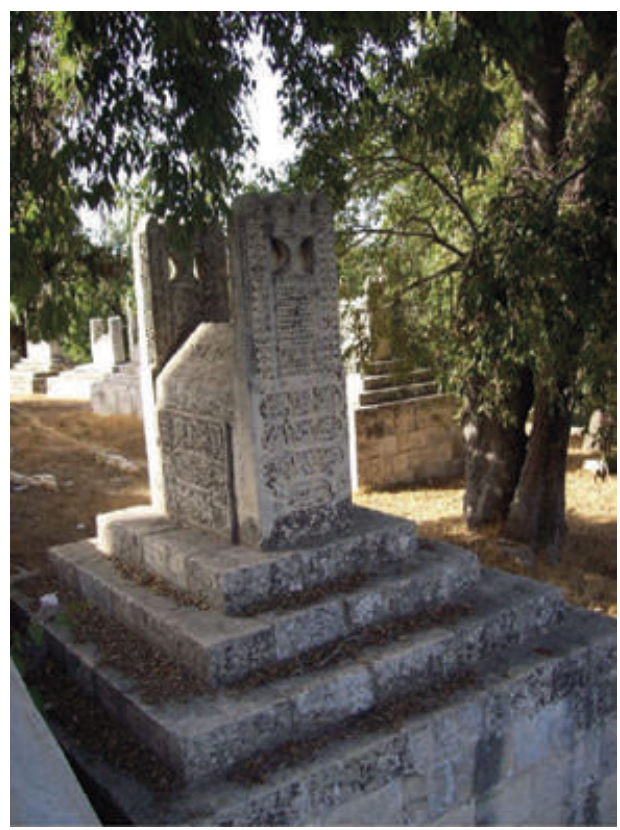

Fig. 17: Cemetery of an exceptional character reserved for a Druze dynastic lineage in Ba'qline, Lebanon. Photo: Salma Samaha, 2008.

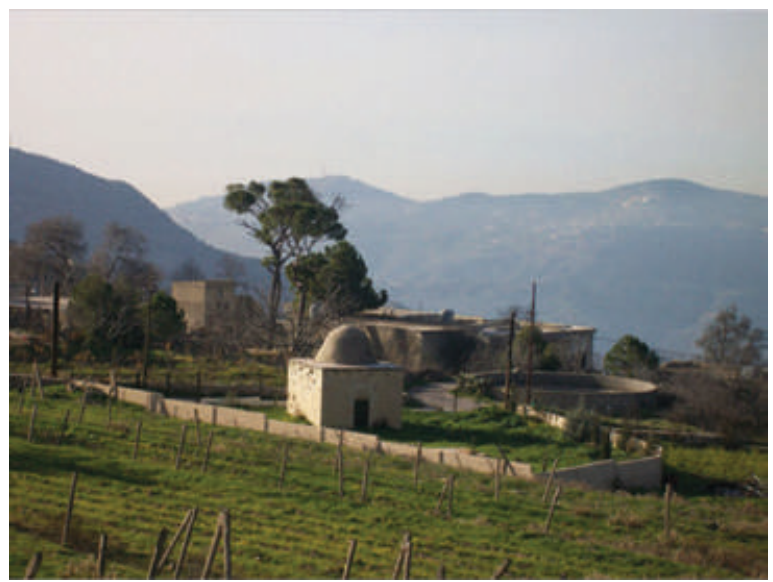

Fig. 18: A Druze private cemetery, reserved mainly for religious sheikhs and those who had the honour to be buried in a place of worship. Shüf, Lebanon. Photo: Salma Samaha, 2008. 


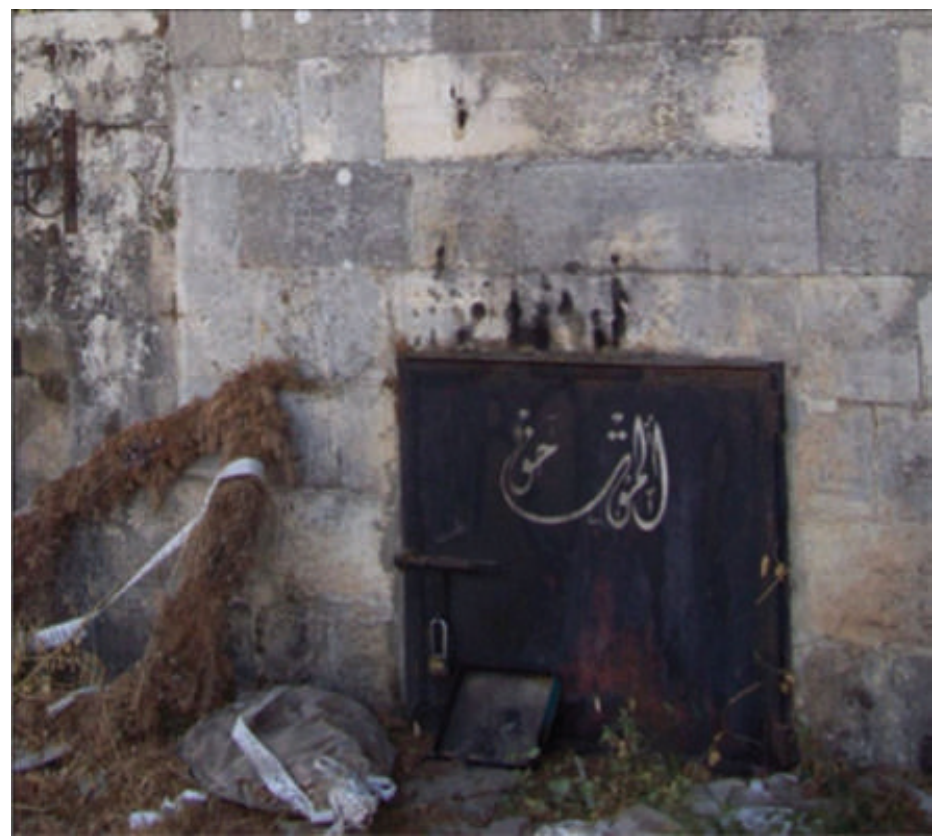

Fig. 19: The door shows the phrase al-mawt haqq, which means "death is right". Shüf, Lebanon. Photo: Salma Samaha, 2008.

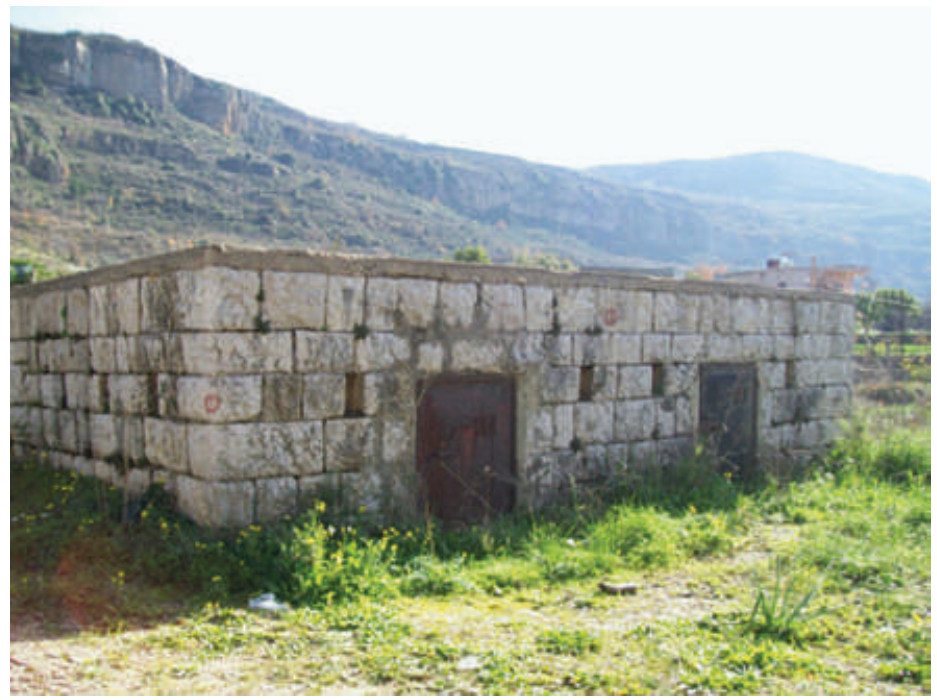

Fig. 20: Druze family grave chambers in Brīh, Lebanon. Photo: Salma Samaha, 2009. 
This system is not limited to this region of Lebanon but found in all the Christian localities in the country. This may be due to the narrowness of the Lebanese territory and its very rugged morphology, which sometimes pushes the inhabitants to build several of these vaults as a continuous linear entity. The other Muslim communities in Lebanon systematically adopt ground burial and superimpose the bodies on top of their relatives after seven years. How can we explain that two different communities share the same way of housing their dead? Why do they not adapt the Muslim burial system, since in Lebanon they are considered Muslims who believe in reincarnation? Outside Lebanon, do the Druze opt for the same typology? It was impossible to find answers to these questions; neither in the related literature nor from various people we spoke to. So it was essential to visit the Suwaydā' governorate in Syria. Our field visit to several villages in 2009 showed us a specific Druze method of burial. It is very integrated into the landscape, so that the spatial impact is only visible inside the plot and almost imperceptible from the outside.

Upon arrival at the first Druze cemetery, we only realised that we had reached our destination when the shaykh began to point to the ground to illustrate his speech. Then we began to distinguish this "drawing", consisting of various groupings of stones stacked in a rectangle, distributed randomly on the natural ground (Fig. 21).

This system consists of digging into the earth a hole with dimensions slightly greater than that of the buried body, which is wrapped in a piece of cloth. In Muslim tradition, it should be covered with natural stones, coming from the site, varying from 15 to $40 \mathrm{~cm}$ in diameter. These stones are randomly arranged until the body is totally buried, and the surface of the ground is levelled. Then a medium-sized stone, similar to those used for covering the pit but with a less bulging and rough sides, is selected for inscription. This includes only the name of the deceased and date of burial (Fig. 22). The date is essential information, because three years later, the pit can be officially reused for another burial. The choice of three years is not random; this is the period necessary for the body to degrade, with the exception of the bones. Various Druze shaykhs encountered during the stay in Syria provided this information.

One can only be attentive to this relatively short period of time adopted by this community, especially since Muslim law allows burial in the same grave only 40 to 50 years after the last burial. ${ }^{1}$ Similarly, since the 1970s, most of the world's civil laws take one of two main approaches to burial: either for a period

1 For more information on Muslim laws, refer to: Philifert Pascale, "Cemeteries Mirror Tradition", available online on the site of the Festival of Geography in Saint-DieDes-Vosges. http://archives-fig-st-die.cndp.fr/actes/actes_2002/philifert/article.htm (accessed 21 February 2018). 
varying between 30 and 50 years depending on the country or free burial offered by the municipality for a minimum 5 years. After that the bones are kept at an ossuary, incinerated and the ashes dispersed in the cemetery grounds or conserved in an urn placed in a columbarium.

As far the Druze community is concerned, the unearthed bones are not incinerated but arranged with skeletons previously taken from a specific corner of the parcel of land dedicated for this purpose. This is done without any particular ritual; double funerals, common practice among some people, are not practised (Deffontaines 1948: 64). Exceptionally, this is relatively recent, as Syrian Druze village cemeteries contain personal vaults built for a particular individual in the manner of those on Shüf mountain, which are used later to cram in all the bones from successive burials.

Since the lettering on cemetery headstones is done using erasable ink, the stones are reused for closing new holes, with the inscription facing downwards, after five years at the most. Previously, when engraving an inscription, the plates were set aside without any organisation or according to any strict rule. There is neither regulation nor a concession system for the graves; the land is free for all. Even the gravedigger is not paid, as the Druze shaykh said, "We do not give him any money for his service just like other Muslim communities. He just does it for his "ajr in heaven".

This method is very representative of a fundamental in Druze faith, namely metempsychosis, the migration of souls and reincarnation. According to this belief, a Druze never dies, since the soul is attracted magnetically by a body with the same sex in formation at the same time as the physical death of its present body. The same souls continue to reincarnate and circulate everywhere, from one body to another, provided that the incarnation happens within the same community and the same circle. Thus, the Druze are always present on earth and have no need to leave an imprint of their passage from earth, since they do not leave it.

This burial method, distinct amongst the Druze, symbolically represents their non-attachment to the body, which they respect by burial until total degradation. This is reinforced by the absence of religious symbols on tombstones, a compulsory practice only in communities which are confessionally diverse. This shows that the symbolism is essentially there for differentiation and is not considered to be sacred.

Note that in Syria, Druze villages systematically adopt this way of burial. But in the rare mixed Druzo-Christian villages in Qatanā district, the Druze, who had previously adopted the Christian way as in Shüf mountain, have changed to specifically Druze burial practice over the last 15 years. During 
our fieldwork, we could not get any explanation regarding this change. The interviewed Christians of the village informed us about this incomprehensible reversal and asked to remain anonymous. The Druze of the village were very reluctant to give information and were pleased to praise the highly positive relations between the two communities: "Absolute fraternity in the resolution of conflicts; total fusion between the crescent and the cross" (ta'akhkhī kāmil fì hall al-mashākil, indimāj kāmil bayna al-hilāl wa-ṣ-ṣalīb).

Among the Christians of Lebanon, the dead fill the landscape in stable and solid constructions associated with the life in the hereafter. The fragile imprint on the landscape typically left by the burial of Syrian Druze is open to interpretation. Why is this burial method not practised in Shüf mountain, in purely Druze villages or in mixed ones in Lebanon? Why did the Druze adopt the Christian way of burial? Is it for leaving a physical imprint on the landscape symbolising their presence in the region, alongside Christians? Is it their practice of "concealment" $(\text { taqiya })^{2}$ that pushes them to adopt the customs of the country where they are? Or is it a tangible representation of the "symbiosis" of these communities, a spatial symbol of the period when they lived in harmony in this area?

2 For a critical discussion of the term taqiya, see Tobias Lang's Chapter in this volume. 


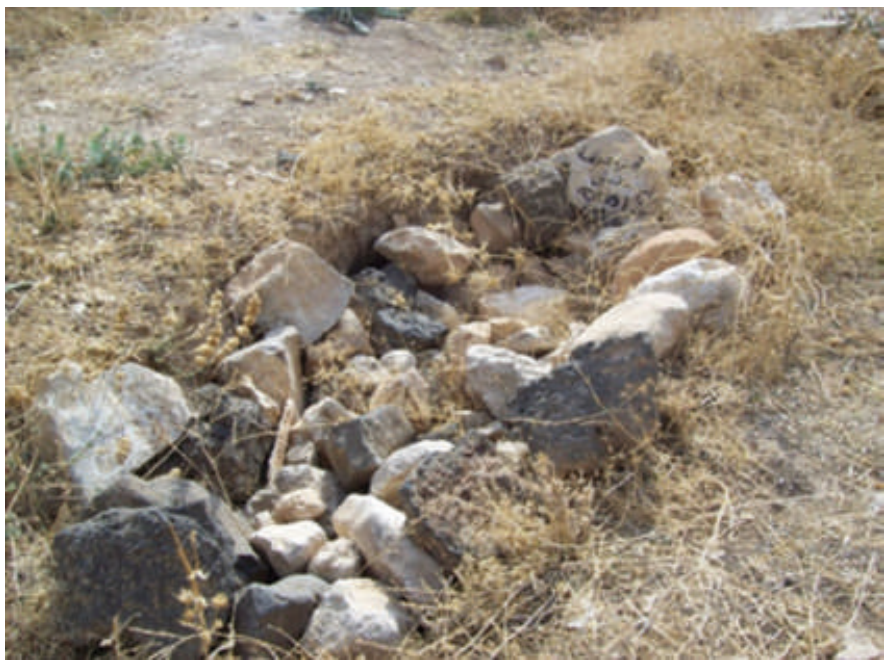

Fig. 21: Various groupings of stones stacked in a rectangle shape, distributed randomly on the natural ground. Harfā, Syria. Photo: Salma Samaha, 2009.

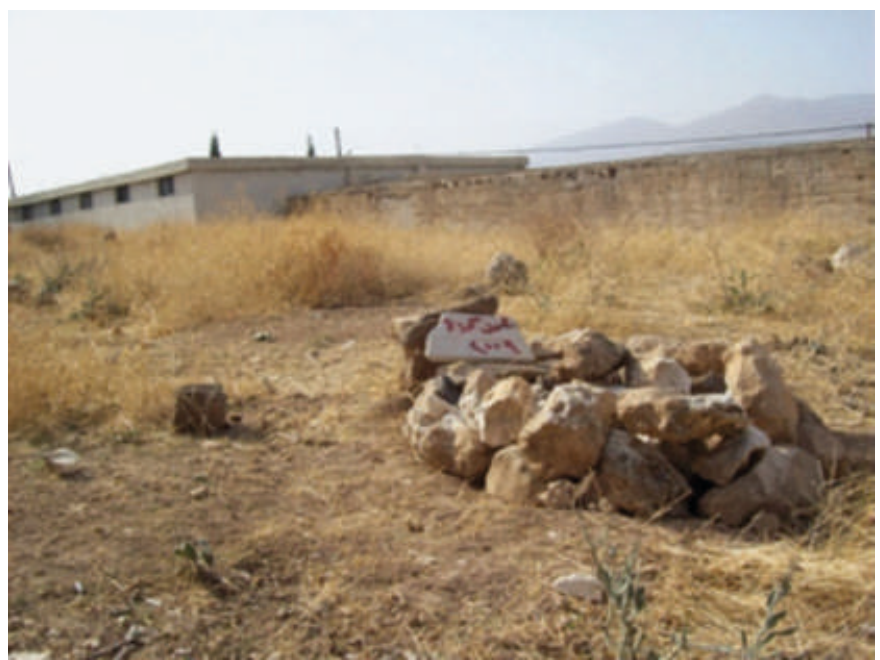

Fig. 22: Inscription includes only the name of the deceased and the date of the burial. Harfā, Syria. Photo: Salma Samaha, 2009. 


\section{Religiously specific versus mixed mortuary dwellings}

It is essential to consider the materialisation of death on a larger scale and the phenomenon as a whole in order to analyse its imprint on the landscape. In the Mediterranean, for example, home burial has long been practised. A small family cemetery was created around the house, an early grouping of the dead in the midst of the living. In Shüf Mountain, some family cemeteries can be found scattered throughout villages, mixed or not, as in Kfar Qațrā or Bārūk.

However, Arabs have contributed significantly to the development of the cemetery, or Greek "dormitory": more or less vast land, removed from all exploitation and assigned to house the dead, in which each grave is individual or familial according to social norms or religious beliefs of the group. Indeed, the Mediterranean region, which saw some of the earliest large agglomerations, is also an area with the first and largest cemeteries. The dead and the living are indeed two very different "peoples" geographically (Deffontaines 1948: 193). As a result, cemeteries are indispensable, especially to communities where incineration is religiously impossible or illegal. Moreover, in Lebanon, cemeteries are most often on lands "handed over to God" (waqf) by believers for a particular use and whose profit is assigned to religious foundations that manage them. Therefore, the religious appropriation of the ground extends disproportionately through the dead. In Shüf Mountain, this type of cemetery can be found in all villages, whether they are purely Christian, Druze or mixed.

The groups of the dead generally correspond to the population living in the surrounding region, the dead being buried close to where they lived. These burial groupings vary in size, concentration and location as much as the living population. They can occupy the central place in the settlement of the living or be completely away from it.

Although sometimes a specific geographical position determines the choice of resting place for the dead, "the mental representations of the afterlife are often populated by geographical references. Religions often open up visions of Land of the Dead whose landscapes can be analysed through the prism of reality landscapes. These representations are geographical because they are based on objective landscape realities" (Dubois 2005: 67). A Christian habit, especially prevalent from the seventh century, is to attach the cemetery to the church, which bring the dead inside the settlement of the living, and sometimes into its centre, as in the villages of Majdal al-Ma'ūsh and Mazra'at ash-Shūf.

The opposite approach was also adopted - placing the cemetery far away from the houses of the living. From the eighth century it was positioned near the church. Soon, the village followed and settled further away from the cemetery, as in the Christian village of Deir Dürit. This phenomenon is also found in the Druze community, which sometimes builds a "prayer house" (khilwa) or 
"community house for the mashayikh [initiated]" in the middle of the cemetery, as in Ba darān, where there is a very old room built of natural stone over a tomb.

The effort made to house the dead is no less considerable than that pursued for the living; the problem of housing does not end with death. Sometimes that is where it gets bigger, or even begins. The cemetery is a space of accumulation more than of production, a major restriction on the logic of profit and profitability at work in humanised spaces, which extends and becomes denser. Thus, for reasons of town planning as well as hygiene, cemeteries and living quarters are dissociated and distanced from each other. Preference is given to segregating the living and dead, and even in exile cemeteries are placed outside villages. The health of the living has triumphed. The dead are taken outside to the least embarrassing place, the secondary entrance, of the Druze village of 'Ayn-wa-zayn and Kfar Hìm; the Christian villages of 'Ammìq, Bayt ad-Dīn, Wādī as-Sitt and al-Fuwāra; or the mixed village of Mazra'at ash-Shūf. Even though the two worlds of the living and dead have been strongly interrelated, made up of exchanges and based on proximity, openness and familiarity, these links are weakened by the profound changes engendered by urban development. The mutation of this traditional coexistence has required the rapid transport of coffins; burial processions have changed speed, most of the time now using cars.

From the moment "when ritual pathways (especially death) are thresholds in time and sacred spaces become thresholds in space" (Park 1994: 246), the cemetery becomes a sacred space, the symbolic place that unites the heavens and earth. Thus, a settlement of the dead is always the witness of a cosmology, a vision of the world, a mystical geography. As a result, cemeteries are logically "specialised according to religion" (Deffontaines 1948: 183) or ethnicity, but also according to communities within the same religion. This is the case throughout the world, in Lebanon and especially in Shüf Mountain, for example in the village of Kfar Qațā, where the Maronite and Greek Catholic cemeteries are distinct. Similarly, while usually "cemeteries do not reconcile theological quarrels" (Dubois 2005: 93), how is it possible to find mixed Druzo-Christian burials in this area? How can this phenomenon be explained, since these two communities have very different visions of their fate after death? Especially since Christians bury their dead in consecrated ground, so that they may rest "in the patrimony of Jesus Christ and so be his co-heirs in the Kingdom of God" (Lawers 2005: 219). In this way, they must be reunited after their death and distinguished from other dead and "strangers". The sacred condenses in these burial places, mainly for physical and historical reasons and thus gives the sacred space its own hierophany. ${ }^{3}$

3 This concept, introduced by Mircea Eliade in his work on the sacred, means that something sacred appears to us, manifests itself. 
However, there are two situations in Shüf mountain: cemeteries are mixed or for adherents to a particular religion only, whether Druze or Christian. Sometimes one cemetery is distinct to each Christian community, as in Nīhā, Kfar Qațrā, Mazráat as-Shūf and Mukhtāra.

This maintains the disparities by marking them even after death. The different cemeteries are easily identified, especially when they are adjoining a church, in the case of the Christian community. But the religious differentiation stands only where one can identify a Christian cross, or more exceptionally the Druze star, alone or in combination with the crescent, suspended above the family vault. This is done in two different ways: hanging them on the side of the door when the roof of the vault is horizontal or on the top of the angled roof when it is stepped like a pyramid.

However, some mixed Druzo-Christian villages also provide mixed resting places for their dead, materialised in the landscape in two different ways. First, a distinct part is reserved to each community. Yet the spatial limits are neither visually strict nor physically materialised by anything. This distinction relates rather to a natural difference, topographical in the case of Brì where the upper side is devoted to Druze while the lower one is reserved for Maronites (Fig. 23). Otherwise, a physical landmark will represent the virtual limit, like the big oak in Ba darān (Fig. 24). Second, totally random distribution of the different communities inside the cemeteries is seen, for instance in Bārūk and 'Ayn Zhaltā. The landscape impact of these mixed cemeteries is identical to purely community cemeteries. The religious distinction will only be visible once inside.

The spatial division of these cemeteries is thus rather variable, but most have fixed limits, especially when they are in the centre of the village, although on the periphery the land may be extended. We are witnessing an ongoing transformation of the cemeteries, which is reflected in modifications suggested by the establishment of an overall plan to organise the remaining free space. Cemeteries like 'Ayn Zhaltā conform to such a plan and rational management for space that has not been organised. There is thus a superposition of several forms of distribution belonging to different periods, such as the appearance of a landscape composed of ostentatious tombs breaking with the old simplicity of the place. Since "cemeteries do not erode social hierarchies" (Dubois 2005: 93); privatisation and the emergence of family appropriation of certain spaces is becoming manifest, as is the appearance of individual affirmation marks through materials used to construct vaults and gravestones. In some areas of the cemetery, it is possible to select a location for future construction, while the floor is traditionally free and unsalable. Some families "buy" well-placed plots of land to build a vault, on the basis of exchanges, including monetary ones. This practice contradicts the religious traditions and customs that have preserved the equality of all before death and encourages the materialisation of "social superiority". 


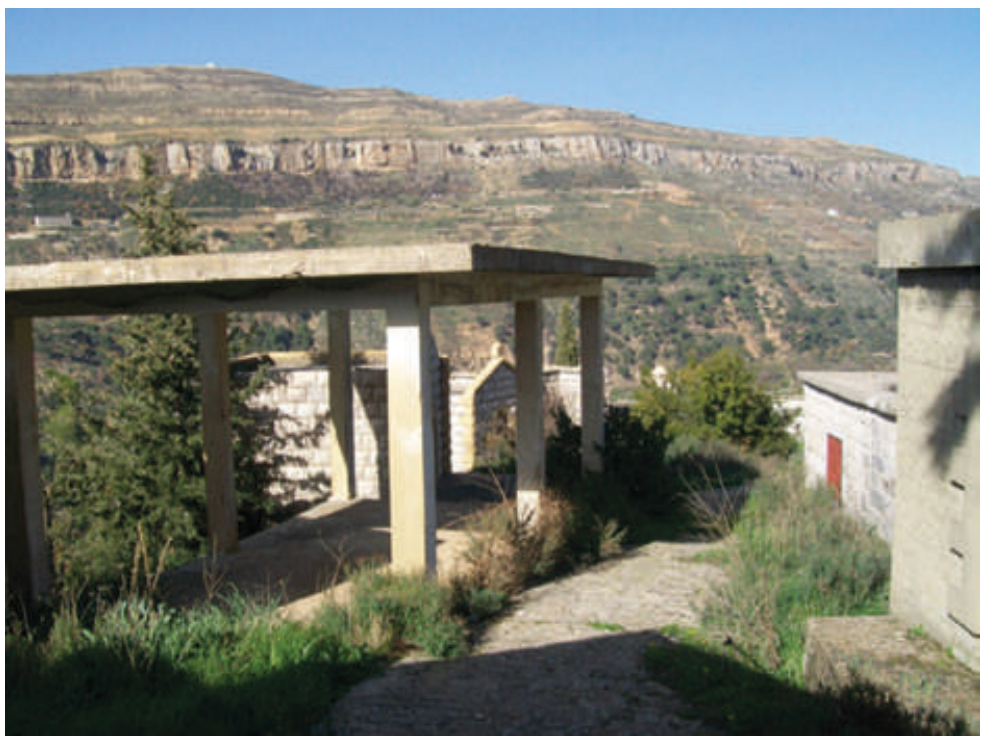

Fig. 23: Mixed Druzo-Christian cemetery in Brīh, Lebanon. Photo: Salma Samaha, 2008.

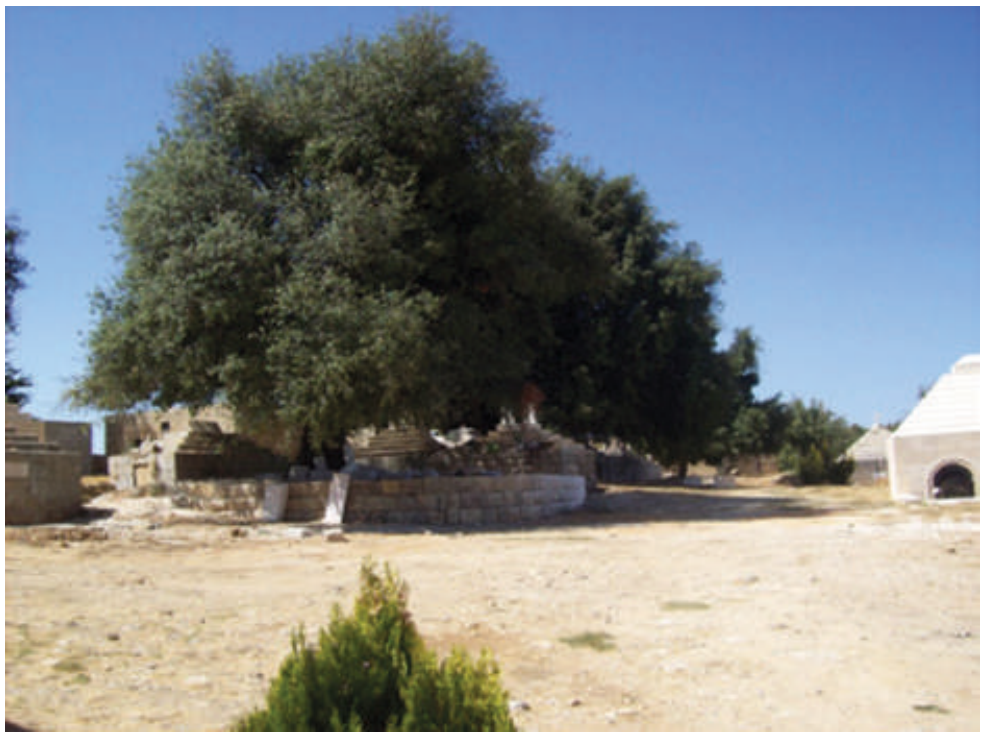

Fig. 24: The oak tree used as a physical landmark representing the virtual division of the cemeteries in Ba darān. Photo: Salma Samaha, 2008. 


\section{Annexes to houses of the dead used as landscape markers}

Just like the habitation of the living, the houses of the dead are surrounded by annexes, making it visible from a distance in the landscape. Other distinctive features include the trees in cemeteries, such as the cypress, chosen because of its longevity and its vertical growth, which represents the elevation of the soul and thus humility before God (Fig. 25). This species is strongly perceived as the "funereal tree" that is reduced to accompany the dead, and thus nobody agrees to plant it in their garden because of this association. Cemeteries usually remain in harmony with the landscape, since the sites are integrated into existing vegetation, whether it is forest species, such as calliprinos oaks in 'Aynwa-zayn, or fruit trees, frequently olive trees as in Mukhtāra (Fig. 26).

The "basic needs" of the houses of the dead include silence necessary for the soul to rest and inviolability, especially when the cemetery is away from homes and easily accessible, as in Bayt ad-Dīn. This cemetery has been equipped with a gate and a fence, non-existent when the cemetery is in the heart of the village, like the mixed cemeteries in Ba darān, Druze in Mukhtāra or Christian in Wādī as-Sitt. Access to these is easily controlled by local inhabitants who can stop people going up the path to cemetery at the top of the hill. Note that only Christian or mixed cemeteries had fences; in our study area, Druze cemeteries did not. Rather, we noted a materialisation of the boundary as in 'Ayn Qini. Most of the time, the design of these wrought-iron fences and gates features religious representations of the community. Tall, stately, pencil-thin cypress trees and a stone wall protect the cemetery from the hustle and bustle of the street outside its walls.

The long-term concern is that the living use the natural stone present in the region to construct tombs and vaults. This stone is used almost systematically among Christians and less frequently among the Druze. The latter also make many vaults in concrete blocks, which are less long-lasting constructions. This may have several explanations, ranging from architectural preferences of the Druze to the little importance they attach to the habitation of the dead, which brings us back to the traditional graves found in Syria. Let us not forget that budget cuts are now pushing individuals from both communities to adopt this more economical material. 
The community of the living must continue to live, which encourages it to sustain the lives of the dead, hence the universality of honouring the dead. The experience of the sacred is shared with the community. To preserve and transmit it, it will have to be codified. In its most spiritualised form, honouring the dead is limited to prayer, which expresses the idea of an enlarged community uniting them with the living. This can be amplified and materialised by offerings of flowers and candles that adorn the site and mark the link between these two "worlds". This practice is very common among Christians and it is also practised by the Druze of Shüf mountain, unlike those of Syria, who do not attach any importance to this home of the deceased.

\section{Conclusion}

This study of how Christian and Druze mortuary dwellings impact on the landscape showed an identical imprint despite the different belief conceptions in Lebanon. Settlements of the dead fill the landscape displaying both communities' presence in the region; both mixed and confessionally separate mortuary dwellings are frequently found. Amazingly, in Syria, the Druze adopt a very distinctive burial method with a very light landscape imprint. At least this was the situation before the Syrian civil war, at the time of pan-Arabism, in which religious segmentation was a political taboo. It remains to be seen to what extent the increasing ethnic territorialisation nowadays will shape the mortuary dwellings of the Syrian Druze. 


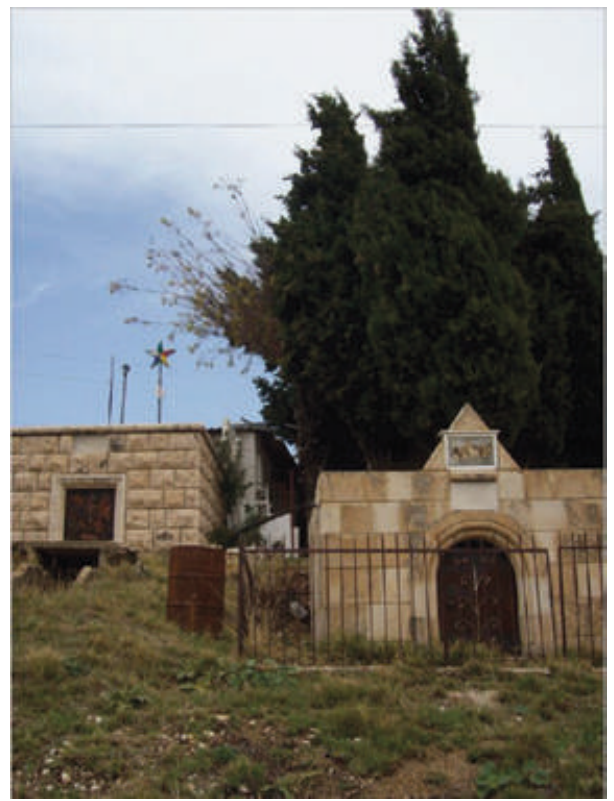

Fig. 25: Cypress trees in the Druze cemeteries of Nịhā, Lebanon, frequently occuring in both Druze and Christian cemeteries. Photo: Salma Samaha, 2008.

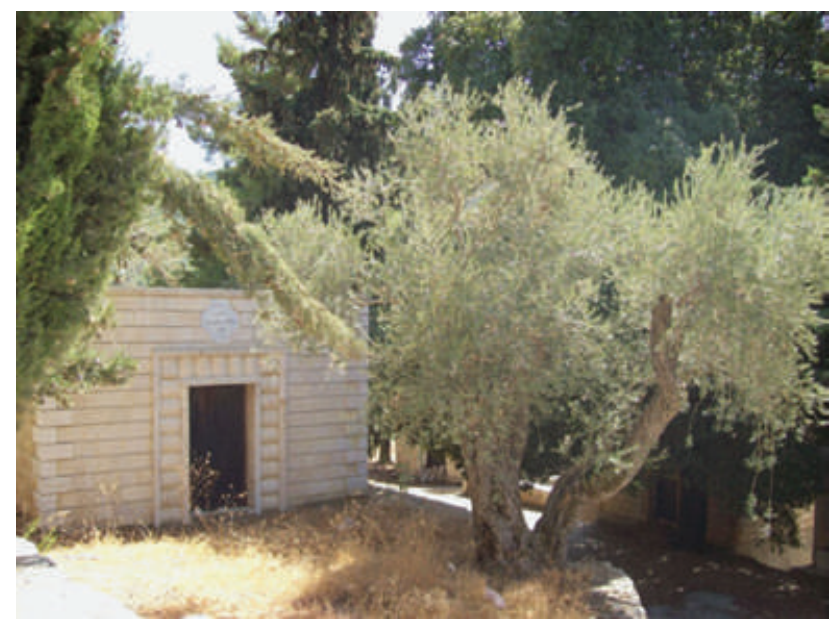

Fig. 26: Olive trees in Mukhtāra Druze cemeteries, also quite frequent in both Druze and Christian cemeteries. Photo: Salma Samaha, 2008. 


\section{Literature}

Claval, Paul. 2003. Géographie culturelle. Une nouvelle approche des sociétés et des milieux, Armand Colin: Paris.

Corm, Georges. 2005. Le Liban contemporain Histoire et société, Édition actualisée, Ed. La découverte poche: Paris.

Deffontaines, Pierre. 1948. Géographie et religions, Gallimard: Abbeville, France.

Dubois, Stéphane. 2005. Le fait religieux dans le monde d'aujourd'hui. Essai géographique, Ellipses: Paris.

European Landscape Convention. 2000. Available on https://rm.coe.int/ 16800805ce (accessed 18 February 2018).

Kackwitz, Kim and Karl J. Lindholm. 2013. Landscapes of mortuary practices. In: Ancient Death Ways: Proceedings of the workshop on archaeology and mortuary practices. Uppsala, 16-17 May 2013; edited by Kim Hackwitz and Rita Peyroteo Stjerna, Uppsala: Institutionen för arkeologi och antik historia, 2015, pp. 143-166.

Lauwers, Michel. 2005. Naissance du cimetière, lieux sacrés et terre des morts dans l'Occident médiéval, In: Aubier Collection historique, Flammarion.

Lenoir, Fréderic et Jean-Philippe De Tonnac (eds.). 2004. La Mort et l'immortalité. Encyclopédie des savoirs et des croyances, Bayard Centurion.

Park, Chris. C. 1994. Sacred world: an introduction to geography and religion. London et al.: Routledge.

Pressman, Peter et al. 1992. Religion, anxiety and the fear of death. In: Schumaker, John F. (ed.): Religion and mental health. New York: Oxford University Press, pp. 98-109.

Samaha, Salma. 2010. L'empreinte des communautés religieuses sur le paysage dans la montagne Druzo-Chrétienne du Chouf au Liban, dottorato di ricerca in Cultura e Territorio, Ciclo del corso di dottorato XXII, Università Roma Due - Tor Vergata.

Tanguy, Frédérique. 1995. Lire le paysage, Paysage \& Aménagement numéro $32,20-26$. 


\section{The Druze as a Political Entity in the Modern State: An Overview of the Contemporary Situation in Syria, Lebanon and Israel}

\section{Introduction}

\section{The Druze in the modern state}

While exploring religious and social practices of the Druze community, it may be useful to include a contribution concerning the political environment the Druze communities are living in. The Druze religion, rather than their language or customs, is what distinguishes them from non-Druze neighbours. Druze do not live in a vacuum, and the political outlook of the Middle East has changed dramatically during the last century. Accordingly, the factors shaping the political behaviour of the Druze changed just as for any other Middle Easterner. In fact, the three states the Druze mainly reside in have come into existence during this period. According to Israeli Druze historian Kais Firro, the new political entities that emerged in the twentieth century are responsible for the differences between Druze communities regarding an important aspect of political behaviour: "Although there are several factors that determine the attitude of the Druze minority toward the majority, the modern state remains the major force" (Firro 1988: 196).

While some separate in-depth case studies covering the Druze communities in the three states as political entities have been published, overarching contemporary work is rare. Therefore, the aim of this chapter is to provide a comprehensive introduction into some political aspects of the Druze community at the end of the 2010s. The intention is to explore the positions of the Druze communities of Syria, Lebanon and Israel in the political landscape of each state and discuss some of factors that determine the respective status quo.

The position of the Druze community in the three states is very different in each case and dependent on many individual factors, mainly demographic features, geography, collective memory, leadership and especially the type of political system. To demonstrate this, a comparative approach is taken here. Methods used are literature research of scholarly work, biographical accounts 
and newspapers together with open-ended interviews with politicians and activists conducted during field research.

\section{A formula for Druze political behaviour?}

Whether a distinct Druze political behaviour exists or not is a matter of debate. Two approaches to this question can be identified. The first can be described as orientalist influenced and highlights the importance of the religious practice of taqiya (mostly translated as dissimulation) as an explanation for Druze political behaviour. According to this line of argumentation, exemplified by the work of Haim Blanc (1952), Druze will always back the "strong horse" yet remain loyal to their respective state. The second approach, exemplified by Kais Firro $(1992,1999)$, argues that taqiya has no special meaning for the Druze.

While the exact usage of taqiya among the Druze is beyond the scope of this chapter, it should be emphasised that explaining Druze political behaviour with religious doctrine in general and taqiya in particular is problematic for multiple reasons. Jakob Skovgaard-Petersen points out that: "When dealing with Muslim minorities in the Middle East, the issue of taqiya is often raised to imply that, whatever representatives of these minorities may say, their statements should not be taken fully at face value" (Skovgaard-Petersen n.d.: 9). Furthermore, if a whole group cannot be trusted, one can ultimately question any individual statement and reinterpret it in a patronising way (Skovgaard-Petersen n.d.: 9, 1998). ${ }^{1}$

The "taqiya approach" also tends to generalise while neglecting the individual factors, which shape each Druze-state relationship. Druze do not live in a vacuum, and while religion and sect often play a role, as individuals they are part of the sociopolitical fabric of the states in which they live and the wider Middle East. Therefore, over the last century, the political activities of Druze individuals have been influenced by diverse wider trends affecting the region, like Arab nationalism, socialism, Syrian nationalism and, in some notable cases, even pan-Islamism. Maria Kastrinou points out that even the designation "the Druze" itself might be problematic since it "overly generalises and homogenises a diverse group" (Kastrinou 2018: 273). A similar criticism of Druze and nonDruze scholars alike is voiced by Amir Khnifess. In reference to Clifford Geertz,

1 For an example of the approach criticised by Skovgaard-Petersen see Nisan (2010: 582). 
Khnifess highlights the usage of culturalism, an approach which "would equate to all Druze following one political course because all Druze are followers of altawhid ["monotheism" here the Druze] religion" (Khnifess 2015: 31).

Keeping in mind these critical approaches, it is important to remember that the Druze are not a homogeneous bloc, even though this chapter focuses on the main trends of Druze political behaviour. Nevertheless, in my previous comparative work on the Druze in Israel and Lebanon (Lang 2013), I identified two main tendencies of political behaviour: group solidarity in times of crisis and pragmatism and realism towards existing or future balances of power.

I am fully aware that readers of this volume might be interested in whether Druze political behaviour is influenced by belief in reincarnation (taqammuss), which is undisputedly widespread. Lebanese anthropologist Fuad Khuri went as far as to argue that belief in taqammus was a main reason for the display of solidarity among the Druze (Khuri 2004: 102-105). ${ }^{2}$ Yet, given the justified scepticism regarding explaining the political behaviour of Druze with religious doctrine and due to my perspective as a political scientist, this question has to remain beyond the scope of this chapter. However, this chapter might provide the reader with some valuable context on the political realities in which Druze live and practise their religion. A discussion of those realities, which may shape religious practice and the understanding of taqammus in particular, might be helpful while reading the other chapters in this book and exploring the differences between Druze communities.

2 Khuri cites the role of the religious mashāyikh as the other main factor, see Khuri (2004: 104, 117-137). For some individual accounts of the interplay between taqammuṣ and political behaviour see Rabah (2016: 109-111). 


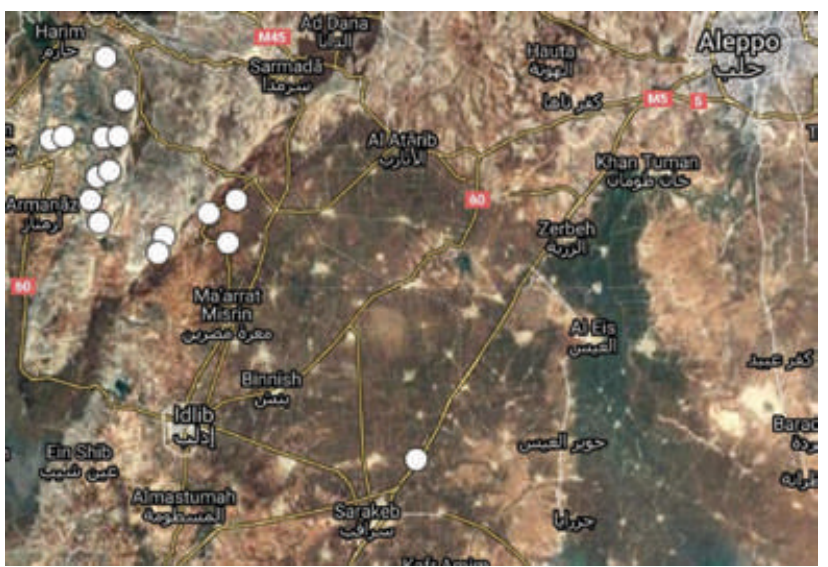

Fig. 27: Topographical map of Druze settlements in northern Syria. Map created using Google Maps, Tobias Lang, 2021.

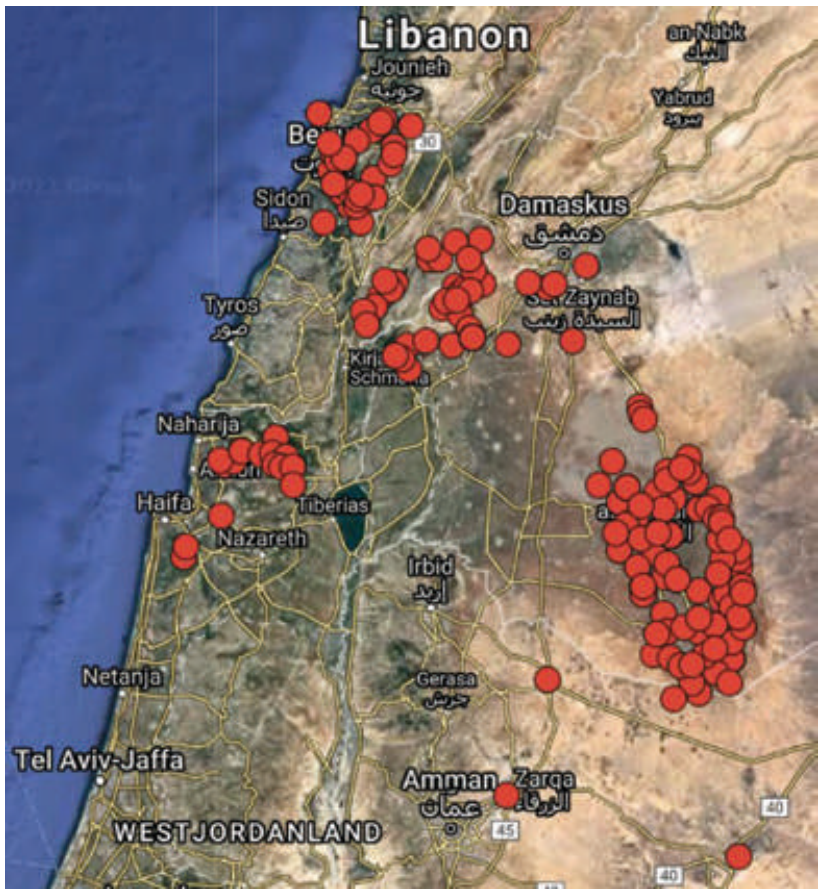

Fig. 28: Topographical map of Druze settlements in southern Syria, Lebanon, Israel and Jordan. Map created using Google Maps, Tobias Lang, 2021. 


\section{Areas of Druze settlement}

Sizeable indigenous Druze communities can be found in the states of Syria, Lebanon and Israel. Jordan is also home to a tiny Druze community, and large emigrant communities exist in the Gulf countries, the United States and South America, especially in Venezuela.

\section{Syria}

Presumably due to the delicate role of the Alawite community in Syria's leadership, for decades official statistics do not differ according to religious affiliation. Still, it is widely accepted that Syria is home to the largest Druze community, estimated by contemporary authors from 500,000 (Dana 2003: 229) to 700,000 (Hazran 2014: 16) or around $3 \%$ of the pre-war population (ibid., van Dam 2017: 14). The majority of Syria's Druze lives in the southern province of Suwaydā', where they constitute the vast majority of the population.

Many Druze have also moved to the greater Damascus metropolitan area. Druze villages had been existing for centuries in the Ghūta plain (Firro 1992: 34) and have become suburbs of Damascus. The most prominent of these former Druze villages is Jaramānā, a city with a pre-war population estimated as high as 200,000 (Kastrinou 2016: 31). Also, Suwaydā' City, the capital of the eponymous mostly Druze populated province, has close to 100,000 inhabitants. Hence, nowadays the Syrian Druze can only partly be described as a rural community.

The Druze populated towns and villages in the greater Damascus metropolitan area blend westwards into the Hermon-Golan region. ${ }^{3}$ Here, a couple of Druze-inhabited villages do exist on the non-Israeli-occupied side of Mount Hermon and the Golan Heights. Additionally, four Druze villages lie in the zone that has been under Israeli occupation since 1967. The northernmost area of Druze settlement can be found in the province of Idlib in the remote region of Jabal al-Summāq and Jabal al-A'lā near the Turkish border.

\section{Lebanon}

In Lebanon, the political system is based on a fragile balance between different sects and for political reasons no census was conducted since 1932. Estimations

3 Mount Hermon (Jabal al-Shaykh; cf. Fig. 2) is a massif which borders Lebanon and Syria and has been partly under Israeli occupation since 1967. The Golan Heights to the south are a more low-lying plateau. 
put the size of the Druze community between 250,000 (Harik 1994: 464) and roughly $385,000^{4}$ or $5-6 \%$ of the Lebanese population (excluding residents without Lebanese citizenship). Areas of settlement include southern Mount Lebanon, foremost the districts of Shüf and 'Ālayh and to a lesser extent the districts of B'abdā and Matn, and the city of Beirut. The districts of Rāshayā and Hāṣbayā on the western and southern slopes of Mount Hermon constitute the most ancient areas of Druze settlement.

\section{Israel}

In contrast to Syria and Lebanon, in the case of Israel one can rely on exact numbers of the Druze population. According to the official Israeli statistics, at the end of 2017, there were 139,300 Druze inhabitants, which are $1.6 \%$ of the total population (Central Bureau of Statistics 2017). This relatively small number gains more significance if we take into account that the Druze constitute about $8 \%$ of the way larger Arab population in Israel. This official number includes also around 20,000 inhabitants of occupied Syrian territory, the overwhelming majority of whom do not hold Israeli citizenship. The community in Israel proper lives in sixteen localities in Galilee and two on Mount Carmel near the city of Haifa.

\section{"A minority with no minority feelings"}

In all three cases, the Druze communities constitute a clear minority in their respective countries. Considering the uncertainty of the numbers concerning Lebanon and Syria, we can still assume that the Druze share of the population is significantly higher in Lebanon than in Syria or Israel. In addition, geographical aspects need to be taken into consideration: the Druze in Israel do not inhabit a heartland, unlike the Druze in the Shüf and 'Ālayh districts of Lebanon or in the Syrian province of Suwaydā'. In southern Mount Lebanon, the Druze constitute a relative - and in Suwaydä' an overwhelming majority. In regard to the Syrian Druze, Albert Hourani coined the term "compact minority" - a minority which is concentrated in a certain geographical

4 My own estimation based on the share of registered Druze voters in 2018 (5.62 \%) combined with the calculation of the of the Lebanese population provided by the World Bank (Atallah and Zoughaib 2019: 5; The World Bank 2018). 
area where it constitutes an absolute majority (Hourani 1947: 14). ${ }^{5}$ Generally, Druze also tend to form the majority in mixed towns or villages. In the words of legendary Lebanese Druze leader Kamāl Junblāt: "They have always been a minority with no minority feelings" (Joumblatt 1982: 38-39). This description is an exaggeration and might also be self-serving but contains a grain of truth, especially regarding Druze self-conception in Syria and Lebanon, as will be demonstrated in this chapter.

\section{The Syrian Druze as a political entity}

\section{From the periphery to the centre of Syrian politics (and back again)}

Due to its peripheral location on the southern border, the mostly Druze province of Suwaydā' had been a semi-autonomous part of Syria until the second half of the twentieth century (Firro 1992). For most of the time until then, the Syrian Druze had been in conflict with the central authority in Damascus, first the Ottomans, then the French and after that the government of the independent state. It was only under the dictatorship of Adíb al-Shishakli (1949-1954) that the Druze were permanently made subject to the central authority in Damascus by the use of extensive force (Landis 1998).

Later, during the 1950s and 1960s, the Bath Party drew many young Druze into its ranks. As for other members of heterodox religious minorities from the periphery, the secular-minded party was a natural choice for young Druze. Like the Alawites, the Druze already had a foothold in the army in that period, since the French had encouraged members of rural minorities to enlist in its colonial force, a policy which would later enable officers from these groups, including some Druze, to dominate the party and subsequently the state (van Dam 2011: 4, 26-27). Even before Hāfīz al-'Asad seized power in 1970, Druze officers had been marginalised by the then already Alawite-dominated military party leadership. An attempt to counter this domination by a coup of Druze officers failed in 1966 (van Dam 2011: 48-61). Hereafter, under the rule of the Asad clan, no Druze was able to occupy any decisive position of national political or military influence. Mostly, one or two rather powerless ministers and one of 21 members of the Ba'th Party's regional command, the highest party

5 Hourani himself adopted the term from the French officer and orientalist Pierre Rondot. See Rabinovich (1979: 710).

6 I am grateful to Rami Abou Diab, who made some valuable comments to a draft version of this section. 
organ, were from the Druze community. Under the rule of the Asad family, the Druze were kept away from power but not specifically discriminated against. However, immigration for economic and political reasons reached an all-time high during the presidency of Bashār al-Asad since 2000, leading to a brain drain (Schäbler 2013: 69, 77).

\section{The question of communal leadership}

The Druze population was subject to the same oppression as other Syrians, and many prominent dissidents are in fact Druze. Nevertheless, the rule of the Asad clan saw some positive developments for many Druze, like integration into state institutions and a general push for modernisation with positive economic impacts, the latter aided by investments from the growing Druze diaspora. All these factors contributed to ending the isolated peripheral status of the community.

The Syrian Druze community had long been politically dominated by a few landowning families, the most powerful being the al-Ațrash family. Sultān Pasha al-Atrrash gained the status of a national hero due to his leadership of the Great Syrian Revolt against the French Mandate regime in 1925-1927. To this day, Sultān al-Ațrash is used as a symbol of Syrian and Arab nationalism or Druze values, depending on the context (Schaebler 1999: 27-31; Schäbler 1996). Until he died in 1982, Sultān al-Ațrash had been the unofficial but widely accepted Druze representative in Syria, even though he never accepted an official post. According to historian Birgit Schäbler, beyond his life, Sulțān al-Atrash "has the important double-function of serving as Arab-national but also Druze-communal hero and is a symbol for both the political self-assurance and the political correctness of the Druzes" (Schäbler 2013: 73).

After the passing of Sulțān al-Ațrash, the three state-appointed religious representatives, the mashäyikh al-'aql [shaykhs of mind or reason], became the highest Druze authority in Syria acting as intermediaries with the population of Suwaydä' on behalf of the regime (Schäbler 2013: 64-65, 77). The mashyakhat al-'aql is actually not a purely spiritual institution; its task is rather to represent the Druze community to the outside and vis-à-vis the state (Harik 1994). In Lebanon, there is currently one shaykh al-'aql, but he is a rather ceremonial figure. Nevertheless, the mashayikh al-'aql are often referred to as spiritual leaders of the Druze by Arab media. In Syria, the offices of the mashayikh al'aql are traditionally reserved to three families: Jarbū'a, Hinnāwì and Hajarī.

During the outbreak of the revolt against the Asad regime in 2011, Husayn Jarbü'a (in office since 1965) was the dominating force of the three. He was a 
staunch regime supporter and vocally denounced the early protests in spring 2011. Husayn Jarbūa and his colleague Ahmad al-Hajarī both died in 2012 and were replaced by relatives. Hammūd al-Hinnāwī, the only one left of the "old" triumvirate, initially became the dominant voice of the mashāyikh al-'aql. According to analyst Garry Gambill (2013), he carried the reputation of being the least co-opted member of the old triumvirate. Despite the leadership of the mashäyikh al-'aql, the lingering turmoil after 2011 quickly made the leadership vacuum of the Syrian Druze obvious.

\section{1 onwards: How to respond to the crisis}

From late 2012 onwards, the Druze in Suwaydā' have been subject to sporadic attacks by rebel forces coming from the neighbouring province of Dar ā. Additionally, kidnappings of Druze began to occur on a regular basis, and armed Druze responded with counter-kidnappings of Sunnis from Dar'ā. The reciprocated kidnappings and later attacks on Druze villages fundamentally damaged the relationship between the mainly Druze inhabitants of Suwaydä and the mostly Sunni population of neighbouring Dar'a (Ezzi 2015: 43-43; Gambill 2013; Al-Dimashki 2013). Due to this increasingly sectarian tension, Druze attitudes towards the revolution gradually became more negative.

It is important to note that initially, the Druze attitude towards the uprising against the regime was not overly negative. Support was sizeable, especially during the early phase in 2011-2012. Many prominent members of the political opposition were Druze, most notably Muntahā al-Ațrash, a daughter of Sulțān al-Ațrash. Anti-regime protests in Suwaydā' City and Jaramānā met with different reactions than in other parts of the country. The demonstrations sparked counter-protests by pro-regime elements, but the security apparatus did not suppress them in the same brutal manner as in other towns like Dar à City. This does not mean that opposition activists from Suwaydā' faced no persecution, but the security apparatus was more restrained in Suwaydā' than elsewhere, at least in public (Ezzi 2015; Gambill 2013).

At first, in 2011-2013, some smaller Druze groups even came under the umbrella of the Free Syrian Army. But there is hardly any evidence of Druze insurgency group activity after that. Druze rebel groups ceased to exist during 2014, either due to the increasing pressure from jihadist Sunni groups in the opposition camp or because of military force by the regime (Al-Dimashki 2013; All4Syria 2013; The Daily Star 2015). At the same time Islamist factions were on the rise, foremost the Syrian branch of al-Qāida, Jabhat al-Nuṣra (since 2016 Jabhat Fath al-Shām) and the self-proclaimed Islamic State (until 2014 called 
Islamic State in Iraq and Syria - ad-dawla al-islāmiyya fì l-Irāq wa-al-Shām). Thereafter it became obvious that the revolution against the Asad regime had adopted a Sunni Islamist approach. This rise of Sunni Islamism in the opposition camp led many Druze who had initially sympathised with the aims of the uprising against the regime to silence their support.

\section{Lingering conflict with the regime}

Despite its limited support for the revolution compared to other provinces, Suwaydä witnessed increasing tensions between segments of the Druze population and the regime during 2014 and 2015. The Druze protagonists who challenged the authority of the regime were not sympathisers of the revolution but Druze clerics. In April 2014, outraged by the arrest of a shaykh by the security forces, religious mashayikh, some of them armed, staged a demonstration in Suwaydā' City. The arrest of mashāyikh, who normally command enormous respect and are widely seen by the Druze as a moral authority, broke a taboo. To calm the situation, the regime used its influence on the mashayikh al-aql and promised concessions (which were not fulfilled) like the recall of the local security chief (Lang 2014; Leverrier 2014). Initially, the regime was successful in calming the situation, yet, this episode illustrates a loosening of its control in Suwaydā and a growing self-confidence in challenging it from certain parts of the Druze population.

From summer 2014 onwards, new actors on the Druze scene had the opportunity to gain more influence - especially in Suwaydā. This dynamic applied foremost to religious mashāyikh, other than the three relatively weak mashāyikh al-aql. After years of tight control by the regime, the only remaining potential leaders came from the religious sphere, since feudal or intellectual alternatives were either non-existing, in exile or simply without significant support.

The first shaykh to seek to occupy this power vacuum was Wahìd al-Bal'ùs, initially a widely unknown figure. Bal'ūs entered the wider public sphere of Suwaydā' in April 2014, when he was a leader of the shaykh-led protest (Leverrier 2014). Subsequently, Bal'ùs became a counterweight to the mashayikh al-aql as well as a militia leader - commanding a self-titled "dignity movement" (rijāl al-karāma, the men of dignity). His fighters were not only engaged in confrontations with Islamist rebel groups but also freed draft resisters from regime custody and removed roadblocks set up by security forces. In a videoed speech, the relatively young shaykh not only lamented the unfair treatment of Druze by the regime but also explicitly accused the regime of treason, citing two events where Druze militiamen were left alone to fight. Bal'ūs referred to Druze 
as being greater patriots than Alawites. The shaykh also strongly criticised the corruption of the regime, going as far as mentioning its alleged oil deals with the Islamic State (YouTube channel ZAMAN ALWASL 2015). This broke a key taboo. While Bal' ùs can be perceived as a mere independent prior to his speech, with it he positioned himself in direct confrontation with the regime.

The dignity movement was dealt a huge blow on 4 September 2015 when Wahīd al-Bal'ūs and other group leaders were killed by a bomb attack on his convoy in Suwaydä' City. Under the leadership of another shaykh, the movement continued its activities until early 2018 . The regime continues to control the province, though reports indicate growing anarchy and lawlessness.

The rise of the dignity movement illustrates the potential of Druze particularism and alienation towards the regime, although the movement did not sympathise with the revolution but reminds one more of the century-long struggle over Druze autonomy.

\section{The Idlib Druze and the Islamist challenge}

The takeover of Islamist forces within the rebel camp not only caused fear and contributed to a decrease in Druze support for the revolution. In some regions, the Druze themselves perceived it as a struggle for survival. This struggle is exemplified by the case of the Druze villages in Idlib province, the only Druze community that came under the control of rebel groups.

A cluster of Druze villages is located in the northern province of Idlib. Remote and relatively small, these seventeen villages ${ }^{7}$ are situated in a Sunnionly environment, almost a unique feature in the Druze context because Druze settlements are generally in religiously mixed areas. Vulnerable and far away from the other Druze areas, the Druze of Idlib have a very different history than the community in Suwaydā. Over the centuries, many Druze villagers migrated to what is today Lebanon and Israel, where the common name Halabi points to this descent. Those who stayed had to arrange living with the Sunni neighbours and local authorities, doing their best not to attract attention. Some villages even contain ruins of old mosques, which is very unusual for all-Druze villages (Firro 1992: 47-49, 165-166). The Idlib Druze can be described as the politically weakest and least important of all Druze communities - also, they have adapted the most to the Sunni environment.

7 Some authors mention only fourteen villages. I am referring to Abu Chakra (2005: 179). 
From 2011 onwards, Idlib province has been a centre of support for the uprising against the Asad regime. As early as the end of 2011, the Druze villages in Idlib were in an area controlled by rebel forces. The Druze of Idlib showed their support for the revolution - although without taking up arms (YouTube channel TheSyrianrev2011 2012; Bar 2012). This adaptation to their neighbours' context worked fine until radical Sunni Islamists started to replace the rather secular Free Syrian Army in the area.

At the end of 2013, the Islamic State in Iraq and Syria was on the rise in northern Syria, quickly gaining territory from other rebel factions and extending its influence into the Druze villages of Idlib. In late December 2013, the local mashayikh signed a handwritten statement of conversion to Islam. Almost instantly, photographs and videos from a Druze prayer house appeared, showing Wahhabi preachers guiding local villagers "back to Islam". Whether the mashayikh had issued the declaration out of free will to avoid further harm or under direct threat is unclear (Abou Diab and Lang 2014).

The Wahhabi indoctrination of the Druze in Idlib continued after other rebel factions had ousted the Islamic State from the area. Subsequently, Jabhat alNuṣra became the dominant force in the Druze villages of Idlib, and this direct rule had several effects on religious and everyday life. For instance, women and girls were obliged to wear a hijāb and school classes had to be separated according to gender. Jabhat al-Nuṣra either blew up local Druze shrines or put pressure on the villagers to destroy them (Choufi 2015; Syria Direct 2015). ${ }^{8}$

The situation escalated in June 2015, when a quarrel between Druze locals and Jabhat al-Nuṣra fighters in the village of Qalb Lawza ended with the death of at least 20 villagers and some Jihadi fighters (Barnard 2015). The outcry in regional media and political lobbying on behalf of the Druze may have prevented further escalation. This episode illustrates the vulnerability of the Druze in Idlib, whose continuation is without exaggeration threatened under the reign of Jabhat al-Nuşra. Forced conversion and migration to other parts of Syria erode the very existence of this tiny ancient Druze community.

During the early summer of 2015, the Syrian Druze, as a whole, came under increasing pressure from Islamist-dominated groups. Not only did the situation in Idlib pose a threat to the very existence of a tiny ancient Druze community, but during the same period Druze regions in Suwaydā' and on the Syrian controlled side of the Hermon-Golan region also witnessed attempts at penetration

8 See also the rather euphemistic and apologetic account by opposition activist Yahya Alous (2014). 
by Islamist and Islamist-dominated militias. All in all, the Druze managed to hold rebel forces off their territory (except Idlib) by a combination of intrasectarian military mobilisation, grim resistance, presumably political pressure on rebel factions by foreign actors and the broader military situation turning in favour of the regime. It is impossible to speculate about the future of the Druze community in post-war Syria, but the mere fact that until early 2018 the Syrian Druze have largely prevented their region from turning into a war zone puts them in a favourable position compared to the majority of Syria's population.

\section{Lebanon: From domination to marginalisation}

Regarding political leadership, the situation in Lebanon is completely different than in Syria. Druze feudal lords had ruled Mount Lebanon for hundreds of years, and until today two dynasties, Junblāt and Arslān, almost solely represent the Druze politically on a national level.

Successive Druze dynasties ruled parts of Mount Lebanon as a de facto autonomous emirate for centuries. During the eighteenth-century reign of Fakhr ad-Dīn al-Mánī II, the Druze Emirate peaked and began to decline (Firro 1992: 28). Druze dominance over Mount Lebanon came to a definite end in the first half of the nineteenth century, while Maronite Christians became more influential with the help of Western powers (Salibi 1965).

When Mount Lebanon became an autonomous entity (mutașarrifiyya) under direct Ottoman rule in 1861, the secondary role of the Druze after the Maronites was institutionalised. Druze nominal power continued to decline with the establishment of Greater Lebanon under the French Mandate after World War I. Subsequently, the Druze share of the population and place in the sectarian hierarchy dropped to fifth position in Greater Lebanon. The Sunni population was now much larger and the main competitor against Maronite hegemony (Lang 2013: 125-126). From being the lords of the mountain, the Druze had become a less politically important community and institutionally marginalised.

In this context it is not surprising that Druze elites had an overly negative attitude towards the new Lebanese state (Firro 2003: 75) which became independent from France in 1943. However, according to Lebanese historian Kamal Salibi, the Sunni elite was more negative than the Druze. While they rejected the sectarian political system and its institutions, Druze elites could often identify with the project of a territorial Lebanese entity in the tradition of Fakhr adDīn (Salibi 1988: 165). In the words of Israeli Druze scholar Yusri Hazran, who 
supports this notion: "the Druze did not seek to eradicate the Lebanese state in toto" (Hazran 2014: 267).

Another aspect of the relationship between the Druze and the Lebanese state is the Druze struggle for a place in the official historical narrative. According to Hazran, Lebanese Druze may also feel that their contribution to Lebanese history is overlooked and underappreciated (Hazran 2014: 241-266). The contribution to Lebanese history is personalised by Fakhr al-Dīn, according to some a forefather of independent Lebanon, or Majīd Arslān, who played an important role in the crucial days of struggle for independence (Schenk 2002: 102).

Overall, the Druze elite is ambivalent to the state: on the one hand, there is a patriotic self-image, on the other hand, according to Hazran, a deep-rooted alienation towards the sectarian state and its always non-Druze leadership. Lebanese Druze had never been subject to majority rule before but were reduced from domination to a marginal role in Greater Lebanon, hence their certain bitterness, which became a driving force for changing the sectarian system and Maronite hegemony (Hazran 2014: 268). In general, there seems to be a conflict between the Druze self-image as lords of the mountain and the rather marginal nominal role in Lebanon's political system based on proportional confessional representation.

\section{Kamāl Junblāṭ and the revolutionary legacy}

According to the unwritten "national pact", the Druze were excluded from the highest offices of the Lebanese state reserved for Maronites (president, commander of the armed forces), Sunnis (prime minister) and Shiites (speaker). The Druze remained fifth behind the Greek-Orthodox in the hierarchy of the political system based on proportional confessional representation.

Druze leader Kamāl Junblāt (1919-1977) aimed to abolish the sectarian system. He was a complex and contradictory political figure. From independence onwards, he developed from a Francophile position to become a revolutionary leader of the anti-establishment camp. He dominated over his competitor Majīd Arslān on the Druze scene and enlarged his following beyond sectarian lines (Cobban 1985: 106-108; al-Khazen 1988). Kamāl Junblāț’s primary tool of political mobilisation was the Progressive Socialist Party (PSP, al-Hizb at-taqaddumi al-ishtirākī), which he founded in 1949 (al-Khazen 1988; Albrecht 2017; Richani 1998). The discourse Junblāt used was highly intellectual and marked by progressive socialism, Arabism, advocacy for the Palestinian cause but also Islam (Schenk 1994) and matched the zeitgeist. He mobilised mass support to become "Lebanon's most powerful Muslim leader" 
(Cobban 1985: 185) on the eve of the civil war. While Kamāl Junblāt aimed to abolish the confessional political system, his Arab nationalism was limited and a mere means to achieve this aim (Hazran 2014: 270). He exemplifies the Druze elites' tendency to reject the confessional system but not the existence of the Lebanese state.

Kamāl Junblāt and his efforts to abolish the confessional political system by almost any means contributed to the outbreak of the civil war in 1975 (Hanf 1990: 503; Harris 1996: 161). However, as we will see later, the outcome of the civil war would bring little improvement for the Druze position in Lebanon's political system.

\section{The pragmatic leadership of Walìd Junblāt}

Kamāl Junblāt was murdered in 1977, presumably by the Syrian regime. He was succeeded by his son Walīd as leader of the Junblātị faction and president of the PSP. Walīd Junblāt became famous for his pragmatism; in the 5 years following his father's murder, he aimed to consolidate his position in the party and the Druze community and quickly integrated into the Syrian orbit. Rapprochement with Syria laid the cornerstone for Junblāț's later reputation as a militarily successful "warlord" and later the transition to political leadership in the post-war republic (Albrecht 2017: 127). He was unable, and maybe also unwilling, to follow the national and cross-sectarian revolutionary ambitions of his father. This fundamental change in political perspective from national to communal-sectarian was reflected within the membership of the PSP. While $41 \%$ of members were Druze when the party was founded in 1949, this rose to 76 \% in 1978 (Richani 1998: 94), a year after Kamāl Junblāț's death. The historian Mara Albrecht plausibly suggests that the share of Druze party members has since increased as most members were then recruited from the traditional following of the Junblāt family in the Shūf Mountain (Albrecht 2017: 174-177). Despite its official secularism, the PSP quickly became a "Druze party" during the civil war and remains so nowadays.

In the course of the Mountain War (harb al-jabal), ${ }^{9}$ 1982-1983, Walīd Junblāt achieved nearly uncontested leadership of the Druze community. $\mathrm{He}$ successfully led the fight against Christian forces in the Druze heartland of Mount Lebanon, which also led to the displacement of thousands of Christian

9 Full-length studies on the Mountain War are surprisingly rare, especially regarding the Druze aspect. A recent contribution is the valuable dissertation by historian Makram Rabah (2016). 
inhabitants. Unlike former periods of the civil war, during the Mountain War Druze military mobilisation was very high compared to other sects (Hanf 1990: 355). Junblāt also oversaw the implementation of an autonomous civil administration in the Druze heartland effectively run by the PSP (Harik 1993), an achievement which further contributed to Junblāț's communal prestige. Nazih Richani also suggests that Junblāt was able to find common ground with the Druze economic elite and attracted support and investments in the PSP fiefdom. Before, this elite had supported the anti-reform line of the Arslān family, seeing the radicalism of Kamāl Junblāt as a threat to their interests (Richani 1990). Junblat dominance and the decline of their traditional rivals from the Arslān family had already begun under Kamāl Junblāt but was cemented by his son Walīd (Lang 2013:149-150; Schenk 2002; Hazran 2014). Walīd Junblāț's dominance in the Druze arena during the civil war is also illustrated by the fact that no infighting occurred among the Druze. While Christians and Shiites suffered bloody internal conflict, the Druze remained united.

While Kamāl Junblāt had aimed to overthrow the confessional system, Walīd Junblāt became a successful communal leader whose national significance is founded on the ability to forge and change national alliances. Within his own community his position is almost uncontested, but he does not enjoy the cross-sectarian popular support that his father had.

\section{Walīd Junblāt and the Druze in post-war Lebanon}

The T⿱ä if Agreement, which ended the civil war and placed Lebanon under Syrian control, did not include any nominal changes to Druze status in the political system. Yet, de facto, the agreement implied two developments unfavourable for Druze interests. Firstly, no key ministry has been awarded to a Druze since Ṭă'if. Before the civil war, a key post, commonly the ministry of defence, had usually been allocated to a Druze, but this practice stopped as the much larger Shiite and Sunni communities began to dominate. Secondly, the T⿱a ${ }^{\prime}$ if Agreement confirmed the hitherto unwritten national pact and hence the exclusion of the Druze from the highest offices. With the Tầ if Agreement, the proportional confessional system and the marginalisation of the Lebanese Druze within it were institutionalised.

Nevertheless, Walìd Junblāt consolidated his power in the post-war republic. His loyalty to the Syrian regime during the civil war was rewarded in postwar Lebanon by the Syrians with favourable gerrymandered constituencies and with ministerial posts, like the minister of the displaced. The latter position with control of a budget of several millions of dollars "greatly facilitated 
his control over the Druze" (Picard 2000: 314). Additionally, Junblāt skilfully forged political alliances, which allowed him to control parliamentary blocs larger than the tiny size of the Druze community would suggest. Most importantly in this regard, he developed a close relationship with Rafīq Harīrì, the powerful Sunni prime minister of the post-war era.

Until the turn of the millennium, Junblāt remained a cornerstone of Syrian hegemony over Lebanon, which was ensured by the presence of Syrian troops and intelligence agencies. However, together with Harīrì, he gradually developed into a vocal critic of the Syrian hegemony in Lebanon (Albrecht 2017: 100, 130-132; Gambill and Nassif 2001; Schenk 2002). After Hariri's murder in 2005, Junblāt and the PSP became leading proponents of the anti-Syrian "March 14" coalition, which successfully demanded the withdrawal of Syrian troops from Lebanon.

The following period in Lebanese politics is marked by the split in two opposing political camps: the mainly Christian, Sunni and Druze "March 14" and the opposing pro-Syrian mainly Shia and Christian "March 8". This antagonism resulted in over a decade of political deadlock and brought the country to the brink of another civil war. In May 2008, the militia of "March 8" took over the western part of Beirut, effectively staging a coup against the government led by "March 14". In the course of the events, the Shiite Hizbullah militia also attacked the Druze heartland in Mount Lebanon. The Druze managed to mobilise fierce resistance and hold off the superior Hizbullah for two days. Nevertheless, Junblāt realised the hopelessness of a longer war against Hizbullah and the wider Shiite population. In this existential crisis Junblāt turned to his traditional rival Ṭalāl Arslān, a member of "March 8" whose supporters had reportedly in some cases fought alongside the PSP, to mediate. Subsequently, Junblāt left "March 14" and reconciled with the regime in Damascus and its Lebanese allies, foremost Hizbullah. (Lang 2013: 157-159.) Over the next few years, Junblāt was very keen to repair the relationship between the Druze and the Shiite population. ${ }^{10}$

With the 2011 uprising in Syria, Junblāt again broke with the Asad regime. Given the increasingly sectarian nature of the conflict in Syria and the rise in attacks by Islamist groups in Lebanon, Junblāt focused more on avoiding Sunni-Druze strife. ${ }^{11}$ Sunnis, like Druze and Maronites, make up roughly $30 \%$

10 Personal conversation with Walīd Junblāț, Beirut 2015.

11 Personal conversation with Walìd Junblàt, Beirut 2015. For an analysis of the lingering Sunni-Druze conflict in 2014-2015 and Junblāț’s position see Lang (2015). 
of the electorate in Shūf, Junblāț's constituency. Hence, safeguarding the status quo and avoiding sectarian conflicts with the Muslim population was increasingly important for Lebanon's dominating Druze leader.

\section{Present and future of Druze leadership in Lebanon}

Since the eighteenth century, the Druze community in Lebanon has been split into two factions: Junblātī and Yazbakī. The traditional antagonism between the now marginalised Yazbaki faction, led by the Arslān family, and the much stronger Junblātī faction, is still important. The factionalism concerns the political - and in former times also the religious - sphere. Each faction had both political leaders and a shaykh al-aql, an office which was unified in 1970 due to the powers of Kamāl Junblāt and under the auspices of a Junblātī shaykh (Schenk 2002; Hazran 2014: 167; Harik 1994; Khuri 2004). All in all, Kamāl and Walīd Junblāt managed to co-opt many members of the Yazbakī faction, which contributed to its marginalisation and Junblātī domination.

Both families, Arslān and Junblāt, are represented by political parties and leave little space for other competitors. Traditional elites, in this case two families, control nearly all political representation of the Lebanese Druze. Thus, electorally the Druze remain a very homogenous group: Only one of the eight Druze MPs elected in 2018 was affiliated with neither Junblāt nor Arslān. ${ }^{12}$

In the current political system, Ṭalāl Arslān and his Lebanese Democratic Party (al-Hizb al-dìmuqrâțī al-lubnānī) own their limited prominence mostly to alliance with the pro-Syrian camp and current president Michel Aoun. It was only after Junblāt had fallen out of Syria's orbit that Arslān founded his party with Syrian support (Albrecht 2017: 103). Arslān's following inside the community is far weaker than Junblāt's. In the 2018 election, six out of the eight elected Druze deputies were from Junblāt's list. The same results also illustrate the relative national influence of Walìd Junblāt, since his parliamentary block counts nine members out of 120 , more than the Druze have allocated seats in the national assembly. Walìd Junblāt is more than a communal leader; he is a national power broker and sometimes even a kingmaker. The weight of his influence is much higher than the nominal size of his own community would suggest.

12 MP Anwar al-Khalīl is a former ally of Walīd Junblāt and affiliated with Shiite speaker Nabih Barrī. Junblāt and Barrī are at most times on good terms. Hence, al-Khalīl cannot be considered as anti-Junblāṭ. 
With the de facto dissolution of the political camps in Lebanon in the course of the election of president Michel Aoun in 2016 and a new electoral law unfavourable to Junblāt's ambitions of controlling non-Druze MPs, his role as a potential kingmaker seems to be shrinking. Nevertheless, Junblāt is still a relevant player in Lebanese politics with a strong grip on "his" Druze community, though he is trying to transfer leadership to his son Taymūr. The future will show whether Junblāti domination of the Lebanese Druze, and the related status of the Druze community in Lebanon, can be maintained under the next generation of leaders.

\section{Israel: Forming a leadership}

In many aspects, the case of the Druze in Israel is very different from that in both Syria and Lebanon. ${ }^{13}$ One important factor is that historically among the villages in what is today Israel, the distribution of land ownership was relatively equal. Therefore, the Druze in Palestine barely developed a regional leadership with landholding as a powerbase. Also because of its relatively small size, the community in Palestine never enjoyed any significance in local politics. The lack of secular Druze leadership in Palestine enabled some religious dignitaries, who in Lebanon are mostly dominated by the worldly sphere, to achieve a relatively powerful position. The Tarif family gained particular influence at the end of the nineteenth century, when they rebuilt the shrine of the prophet Nabi Shuayb (Firro 1992: 315-319). Until recent times, the shrine with its religious endowment (waqf) has been a major source of influence for the Tarif family.

After Israeli independence, the Tarîfs were not only willing to cooperate with the authorities but delivered an important religious argument for Jewish-Druze cooperation. It was argued that the prophet Nabì Shu ayb was in fact none other than the father-in-law of Moses: Jethro. According to this argument, the Druze and Jews were in-laws. The shrine of Nabì Shu'ayb became the symbol of a distinct Israeli Druze identity in the years to come (Firro 1999: 77, 2005; Parsons 2000: 123-127). The Tarif family successfully managed to link the interests of the state, which aimed for Druze cooperation, with their own interests of predominance inside the community. Subsequently, after independence, the Israeli government entitled Shaykh Amin Tarif "head of the community" and officially declared the Druze a separate religious group (Khnifess 2015: 115-116).

13 For a recent critical study of Druze politics and state policies vis-à-vis the Druze in Israel see the dissertation by Amir Khnifess (2015). 
It is important to emphasise that the supremacy of the Tarif family was not limited to spiritual matters and was sanctioned first by the British Mandate, not the Israeli state. Under Israeli control, the position of the Tarif family was consolidated and crucially strengthened.

While the Tarif family only started to cooperate with the Israeli authorities during the course of the first Arab-Israeli war, local leaders from mostly secondary families had established closer contacts with the Zionist movement during the Mandate period. Some of these Druze leaders were awarded prestigious positions, like membership of the Knesset, the Israeli parliament. Along with the Tarif family, those leaders with Zionist pre-war contacts would form the nucleus of a distinct Israeli Druze leadership in the years to come (Firro 1999; Gelber 1992).

It can be concluded that in the early years, the State of Israel not only coopted existing Druze leaders (such as the Tariffs) but was also the deciding factor in forming a new distinct Israeli Druze leadership (Lang 2013).

\section{Contemporary Israeli Druze leadership}

The Jewish state was the deciding factor in forming a distinct Israeli Druze leadership, but how was it structured? Who makes up the elite of the Israeli Druze community nowadays?

In 1993, Shaykh Amin TTarif passed away at an advanced age. Before he died, he named his grandson Muwaffaq as successor. A group of Druze leaders opposed this hereditary succession and tried to introduce democratic legitimisation of the spiritual leadership, but the then ruling Labor Party successfully blocked such efforts. Shaykh Muwaffaq Tarif and his family seem to have lost much of their influence over the last two decades and today are often seen as representing government interests and as highly corrupt. ${ }^{14}$ However, lately Shaykh Muwaffaq has quite skilfully tried to regain some political terrain by carefully advocating the "Druze cause" vis-à-vis the government in opposition to the controversial Israeli "nation state law" or as an advocate for the Druze in Suwaydä.

While over the last few decades the spiritual leadership has lost much of its influence, Druze participation in Israeli party politics has increased. The composition of the Knesset gives the impression that the Druze are quite well

14 Observation based on my conversations with Israeli Druze leaders and academics in 2009 and 2011. See also Dana (2003: 80-82), Scheck (2002: 417-419), Firro (2005: 237-238). 
integrated into Israel's political system. In the beginning of 2018, the Knesset had four Druze members out of 120, proportionally twice their share of the total population. Druze deputies belong to the whole party spectrum, excluding the Jewish ultra-Orthodox parties. However, most of these deputies do not owe their seat to their position inside the Druze community. This is exemplified by the case of Ayyūb Qarā from the Likud party. Qarā was the first ever Druze minister with portfolio and the second non-Jew to hold such a position. Yet, in the 2015 election, the Likud received only $6.6 \%$ of the votes in localities with a Druze majority - even the electoral performance of the Jewish Orthodox Shas party was stronger in Druze villages (Rudnizky 2015: 6). Druze politicians can climb the ranks of Israeli parties without gaining significant electoral support from their own community.

Apart from in the Knesset, Druze can be found in other higher political positions, mostly without significant influence, like deputy minister or minister without portfolio. In public services, the Druze are generally underrepresented with the exceptions of the education and security sectors. The latter, of course, is of special importance in Israel.

Ideologically, the Druze elites in Israel can be divided into four categories (Lang 2013: 117-118). No category is homogenous or coherent and hybrid forms are possible. Ideologically, the elites can be classified as follows:

The first category has accepted the particularistic Druze identity promoted by Israel. Representatives of this group see themselves foremost as Druze, not as Arabs. In party politics, they support the centre-left parties, traditionally the Labor Party, although support is declining, in former times Kadima and before that even the Likud.

The second category differs from the first especially on Druze ethnicity. The main difference to the first group is that members see no contradiction in defining themselves as Druze, Israeli and Arab at the same time.

The third category covers members of the Druze elites in Israel that totally identify with Zionism. Former communication minister Ayyūb Qarā is the best-known example. Concerning the peace process with the Palestinians, this category of Druze leaders has hawkish views and voices strong opposition to the creation of a Palestinian state. In party politics, there is closeness to the Likud, but over the years this support has shifted to Yisrael Beiteinu, with popular Knesset member Hamad 'Ammār.

The fourth category is the pro-Palestinian or pro-Arabic faction. Members define themselves as Arabs, Muslims and Palestinians. They mostly support Arab or mainly Arab parties, like the communist-dominated Hadash or nationalist Balad, and oppose both the definition of Israel as a Jewish state and 
compulsory conscription. The late poets Samịh al-Qāsim (d. 2014) and Salmān Nātūur (d. 2016) were known proponents of this tendency.

Inside these groupings, members may have irreconcilable differences, and such conflicts may even have the character of clan feuds. These circumstances complicate any attempts to create an effective political organisation of the Druze in Israel (Lang 2013: 118-120). In the first group, the level of fragmentation is especially high. Hence, creating a democratic legitimised body to represent the community is very difficult. One should also keep in mind that for decades the state did its best to preserve the status quo.

The high level of fragmentation inside the Israeli Druze elite is an evident contrast to the situation in Lebanon, where the feudal leadership of two families persists until today. Israeli Druze fragmentation is demonstrated by the voting pattern: In the Knesset election of 2015, only the Labor-dominated Zionist Camp managed to receive over $20 \%$ of the votes in villages with Druze majority. Overall, $80.9 \%$ went to Zionist parties, while only $19.1 \%$ voted for the Arab Joint List and a minor Arab party. The so-called Arab sector in Israel represents nearly the complete opposite view, with Arab parties receiving $83.2 \%$ of votes (Rudnizky 2015: 6). This voting behaviour demonstrates that the Druze are politically separate from the rest of the Arab population in Israel.

Generally speaking, in Israel the relationship between the Druze on one side and the Muslims and Christians on the other can be considered to be distant. Violent sectarian-toned clashes in mixed villages are far from unknown. Conscription makes dealing with state authorities and the Jewish-dominated majority society easier for the Druze but at the same time it is a burden on the relationship with the Arab population in Israel.

\section{The policy of de-Arabisation, the narrative of blood bond and its limits}

The big difference separating the Druze from the Muslims and Christians in Israel is conscription for all male Druze, with the exception of the 'uqqāl, who are initiated in the secrets of the Druze religion (we can see here a parallel to the case of the Jewish ultra-Orthodox, the Haredim). American sociologist Lisa Hajjar found that not only do the Druze in Israel feel different because of their military service, but also Muslims and Christians see them as different (Hajjar 2000). Of course, groups linked to the fourth category of Druze leaders deny such differences for ideological reasons.

Overall, in Israel, the Druze relationship with Muslims and Christians can be considered to be distant because the Druze serve in the Israeli armed forces. 
This process of Druze alienation from the rest of the Arab population due to military service became obvious during the first intifäda. While the image of the Druze was heavily damaged in the eyes of Christians and Muslims in Israel and the occupied territories (Hajjar 2000: 308), attempts by Druze activists to achieve solidarity with the intifä $d a$ had little success, because their own (Druze) soldiers overwhelmingly saw the Palestinians as the enemy. ${ }^{15}$ Therefore, criticism of the military and its dealings with the Palestinians are not often heard inside the Druze community. Moreover, Druze politicians of Zionist parties and religious leaders are frequently cited by the media as vocal, outspoken and sometimes even radical supporters of the Israeli Defence Forces (IDF), which deepens the rift between the Druze and the rest of the Israeli Arab community.

If we assume that the Druze in Israel have a different status from Muslim and Christians mainly through conscription, it is worth taking a closer look at its legal basis. The Israeli law on conscription dates from 1951. In principle, it obliges every citizen to conscription in the armed forces, but the defence minister is allowed to exclude whole demographic groups. Such exclusion can be pronounced for religious or political reasons. On this basis, the whole nonJewish population and the ultra-Orthodox were excluded from conscription. The Druze and the smaller Circassian community were also excluded from compulsory military service; at first both were recruited on a volunteer basis but only to a limited extent. Since 1956, male Druze and Circassians have also been subject to conscription. The main argument for excluding non-Jews from conscription is the potential conflict of loyalty in the case of war between Israel and its Arab neighbours.

In this context, it becomes clear why in 1957, a year after being made subject to conscription, the Druze were declared not only a separate religious group but also a separate nation. Hence, the Israeli policy of de-Arabisation (Lang 2013) towards the Druze had become written law. The Druze were not Muslims anymore, neither were they officially Arabs. The assignment of Druze in the Israeli armed forces against the Arab and Muslim dominated armies of its neighbours could now be better argued. This line of argumentation ignores the main argument for excluding non-Jews from conscription: possible conflicts of loyalty. Druze live and serve in the army in Lebanon, in Syria and in Jordan. During the invasion of Lebanon in 1982-1983, Israeli Druze experienced such conflicts of loyalty (Lang 2013; Rabah 2016: 187-198).

15 Personal interview with Salmān Nātūr, Haifa 2011. 
Compulsory military service also serves as a vehicle for Israeli Druze to make political demands on the government. Former Knesset member and community activist Zaydān Ațshī considers military service as very important and the IDF as the only public institution in which Druze are really treated equally and can rise to the highest ranks. He argues that military service is the only reason why Israeli governments have met several political demands of the Druze. As example, he cites influencing Israeli policy during the invasion of Lebanon in 1982-1983 or mediating between the government and the Druze living on the occupied Golan Heights (Atashi 1997). Druze can indeed rise to high ranks in the IDF or the paramilitary border police, and the first Druze brigadier was appointed in 1986. A closer look at the successful campaign by Israeli Druze on behalf of the Lebanese Druze during the Lebanese Civil War reveals that military service was indeed the gravest argument for Druze interests in the public debate (Lang 2013: 84-90).

How does the loyalty of the Druze towards the State of Israel manifest itself in the armed forces in practice? The Druze-dominated Minorities Unit was established in 1948, took part in the first Arab-Israeli war and was sent into a combat zone for the first time in the West Bank in 1967. Ever since, Druze soldiers have taken part in all of Israel's wars, and like their Jewish comrades many did not return alive. Subsequently, the narrative of a "blood bond" between the State of Israel and its Druze citizens became widely accepted. Despite the activities of pro-Arab or pro-Palestinian groups, the draft rate among the Druze is about $83 \%$ according to Mordechei Nisan, which is significantly higher than among the Jewish population (Nisan 2010: 577). Druze who object to conscription or service in the reserve have to anticipate heavy sanctions from the state. Mostly, conscientious objection is not accepted in the Druze society and is considered as abnormal behaviour. Objection is only possible if supported or at least tolerated by one's own family, otherwise social sanctions could be imposed (Hajjar 2000: 308-309; Kashua 2004: 15).

The actual overall benefit of military service for the wider Druze population remains questionable. Druze definitely do have the opportunity to find a job in the security sector and make a career following basic military service. Military service provides Druze with an opportunity to integrate into Jewishdominated Israeli mainstream society. Often, the only friendships Druze have with Jews date back to their military service. Druze also have access to public grants, which depend on military service and thus are denied to Christians and Muslims (Hajjar 2000: 308, 311).

Generally speaking, according to the study by Hajjar, Druze soldiers in the army feel that they are treated equally to their Jewish comrades - in sharp 
contrast to their civilian life. Statements that Druze only feel equal to Jews when they are wearing their uniform or are only treated equally in the army are common (Hajjar 2000: 310-311). "Druze deserve better" is an often-used phrase in this context. ${ }^{17}$ In reality, the Druze are not treated equally in most fields. Land expropriation and major discrimination by the authorities continue until nowadays. A common complaint is the comprehensive denial of building permits, which automatically excepts one from state funding - a major problem for young families. Druze villages are also generally disadvantaged regarding funding or the creation of development areas. ${ }^{18}$

Due to land expropriation, the Druze have lost most of their property and thus agriculture as a source of income. In Druze villages in 1950, the average property per capita was 19.6 dunam (19,600 square metres), whereas in 1995, this number was reduced to 0.8 dunam (Firro 1999: 141). Apart from the ongoing land expropriation, the "Kaminitz law", which includes penalties for illegally built homes, and the "nation state law", which defines Israel as the exclusive nation state of the Jewish people, have the potential to fundamentally damage the relationship between the State of Israel and its Druze citizens. In response to this discrimination, Druze protests have been frequent since the 1980s, and in recent years, these have more often turned into violent clashes with the police. Amir Khnifess argues that the main reason why a politics of violence has evolved is the policy of the successive Israeli right-wing governments "to expropriate the last unsettled dunams from Druze villagers" (Khnifess 2015: 272). The level of frustration over the actual value of the "blood bond" is definitely high among Israeli Druze, including the traditionally loyal elites. ${ }^{19}$

Conscription makes dealing with state authorities and the Jewish-dominated majority society easier but also places a burden on the relationship with the Arab population in Israel and does not prevent discrimination by the state.

16 This complaint was also voiced by former diplomat and Knesset member Zaydān Ațshì. Personal interview, 'Isfiyā 2009.

17 This is exemplified in an opinion piece by former Likud-lawmaker As'ad As'ad (Asad 2009).

18 Personal interview with Zaydān Ațshī, 'Isfiyā 2009. See also Khnifess (2015: 218-224).

19 See the opinion pieces by Rafìq Halabī, a former journalist and current mayor of the largest Druze town, Dāliyat al-Karmal (Halabi 2010); ambassador Bahīj Mansūr (Mansour 2014); As'ad As'ad (Asad 2009). All belong to the first and second categories of the Israeli Druze elite. 


\section{Concluding remarks}

The status of the Druze communities in the political systems of Syria, Lebanon and Israel fundamentally differs. In Syria, the Druze constitute the majority of the population in just one of fourteen provinces. The case of the Syrian Druze exemplifies that, in times of turmoil, living on the periphery could have advantages. Until early 2018, the Druze may have been the minority that managed best to stay out of the violent sectarian conflicts in Syria. This is of course not a bad foundation for claiming a space in a future post-war Syria.

In Lebanon, the Druze are one smaller sect of many in a political system based on proportional confessional representation. Here, the Druze are currently disproportionately influential in national politics but only due to the manoeuvres of Walīd Junblāt. Once he leaves the political stage or his power significantly decreases, the status of the Druze in Lebanese politics may decline.

The Israeli Druze are best described as a minority with a special status within the larger minority group of the Arabs in Israel. So far this status has provided little protection against the discriminatory policies of the Israeli government.

As Kais Firro (1988) has stated, in these minority-majority relationships, the modern state remains the deciding factor and the main explanation for developments in the diverse Druze communities. Considering the three very different cases, it can be concluded that, generally speaking, the Druze have found a niche in each state. Thus, in the years to come Druze politicians may be able to leave a mark on their respective state's politics and at least contribute to the religious mosaic of the region.

However, as a minority without natural allies, the existence of the Druze depends on coming to an arrangement with more powerful actors. In Israel, these are the dominant Jewish majority population. In multi-confessional Lebanon, where no clear majority exists, alliances can be forged or broken depending on current interests and the broader political situation. In war-torn Syria, where balance of power is indeterminate, particularism combined with the defensive option of military mobilisation could provide a formula for safe transition into a post-war future.

\section{Literature}

Abou Diab, Rami and Tobias Lang. 2014. The alleged conversion of the Druze in Idlib province. In: MENA Minorities. <http://menaminorities. blogspot.co.at/2014/01/the-alleged-conversion-of-druze-in.html> (accessed 5 March 2018). 
Abu Chakra, Eyad. 2005. The Druzes and Arabism. In: Salibi, Kamal (ed.): The Druze: realities and perceptions. London: Druze Heritage Foundation, 171-182.

Al-Dimashki, Salem. 2013. Syria’s Druze Grapple With Jabhat al-Nusra. In: Al Hayat via Al-Monitor 8 February 2013. <http://www.al-monitor.com/pulse/ ar/politics/2013/02/druze-syria-jabhat.html> (accessed 10 September 2016, not accessible anymore).

al-Khazen, Farid. 1988. Kamal Jumblatt, The Uncrowned Druze Prince of the Left. In: Middle Eastern Studies 24:2, 178-205.

Albrecht, Mara. 2017. Krieg der Symbole: Politische Parteien und Parteienkultur im Libanon (1975-2015). Berlin: Lit. Verlag Dr. W. Hopf.

All4Syria. 2013. Sedition Between Druze and Sunni Fighters Oct. In: The Syrian Observer October 10th, 2013. <http://syrianobserver.com/EN/News/25915/ Sedition+Between+Druze+and+Sunni+Fighters $>$ (accessed 5 March 2018).

Alous, Yahya. 2014. The Druze of Idleb: An Example of Positive Coexistence. In: The Syrian Observer December $15^{\text {th }}, 2014$. <https://syrianobserver. com/EN/features/31459/the_druze_of_idleb_an_example_of_positive_ coexistence.html> (accessed 5 March 2018).

Asad, Asad. 2009. Druze deserve more. In: ynetnews June 23, 2009. <http://www. ynetnews.com/articles/0,7340,L-3735676,00.html> (accessed 5 March 2018).

Atallah, Sami and Sami Zoughaib. 2019. Lebanon's Parliamentary Election of 2018: Seats, Coalitions, and Candidate Profiles. Policy Paper January 2019. Ras Beirut: The Lebanese Center for Policy Studies.

Atashi, Zeidan. 1997 (1995). Druze and Jews in Israel: A Shared Destiny? Brighton: Sussex Academic Press.

Bar, Herve. 2012. Syria Druze Back Sunnis' Revolt with Words But Not Arms. In: The Daily Star Sep. 08, 2012. <https://www.dailystar.com.lb/ArticlePrint. aspx?id=187193\&mode $=$ print $>$ (accessed 5 March 2018).

Barnard, Anne. 2015. Syrian Druse Reconsider Alliances After Deadly Attack. In: The New York Times 11 June 2015. < https://www.nytimes.com/2015/ 06/12/world/middleeast/nusra-front-druse-syria-attack.html $>$ (accessed 5 March 2018).

Blanc, Haim. 1952. Druze Particularism: Modern Aspects of an Old Problem. In: Middle Eastern Affairs 3:11, 315-321.

Central Bureau of Statistics. 2017. Statistical Abstract of Israel 2017, No. 2 Subject 2. The State of Israel. <http://www.cbs.gov.il/reader/shnaton/shnatone_new. htm?CYear=2017\&Vol=68\&CSubject $=2>($ March 5 2018). 
Choufi, Firas. 2015. Agreement Between Walid Jumblatt and Al-Nusra Front. In: Al-Akhbar English, March 3, 2015. <http://english.al-akhbar.com/ content/agreement-between-walid-jumblatt-and-al-nusra-front> (accessed 3 March 2018).

Cobban, Helena. 1985. The Making of Modern Lebanon. London: Routledge.

Dana, Nissim. 2003. The Druze in the Middle East: Their Faith, Leadership, Identity and Status. Brighton: Sussex Academic Press.

Ezzi, Mazen. 2015. A Static Revolution: The Druze Community. In: Friederike Stolleis (ed.): Playing the Sectarian Card: Identities and Affiliationsof Local Communities in Syria. Beirut: Friedrich-Ebert-Stiftung, 39-70.

Firro, Kais. 1988. The Druzein and between Syria, Lebanon and Israel. In: Esman, Milton J. and Itamar Rabinovich (eds.): Ethnicity, Pluralism, and the State in the Middle East. Ithaca, NY: Cornell University Press, 185-97.

Firro, Kais M. 1992. A History of the Druzes. Leiden: Brill.

Firro, Kais M. 1999. The Druzes in the Jewish State. Leiden: Brill.

Firro, Kais M. 2003. Inventing Lebanon. Nationalism and State under the Mandate. London: I.B. Tauris.

Firro, Kais M. 2005. Druze maqāmāt (Shrines) in Israel: From Ancient to Newly-Invented Tradition. In: British Journal of Middle Eastern Studies $32: 2,217-239$.

Gambill, Garry C. 2013. Syrian Druze: Toward Defiant Neutrality. Middle East Forum. <http://www.meforum.org/3463/syrian-druze-neutrality> (accessed 5 March 2018).

Gambill, Garry C. and Daniel Nassif. 2001. Walid Jumblatt, Head of the Progressive Socialist Party (PSP). In: Middle East Intelligence Bulletin 3:5. United States Committee for a Free Lebanon and Middle East Forum. <http:// www.meforum.org/meib/articles/0105_ld1.htm> (accessed 5 March 2018).

Gelber, Yoav. 1992. Antecedents of the Jewish-Druze Alliance in Palestine. In: Middle Eastern Studies 28:2, 352-373.

Hajjar, Lisa. 2000. Speaking the Conflict, or How the Druze became Bilingual: A Study of Druze Translators in the Israeli Military Courts in the West Bank and Gaza. In: Ethnic and Racial Studies 23:2, 299-328.

Halabi, Rafik. 2010. My State Is Giving Up on Me. In: Haaretz 06.07.2010. < https://www.haaretz.com/1.5144769> (accessed 5 March 2018).

Hanf, Theodor. 1990. Koexistenz im Krieg. Staatszerfall und Entstehen einer Nation im Libanon. Baden-Baden: Nomos Verlagsgesellschaft.

Harik, Judith P. 1993. Change and Continuity among the Lebanese Druze Community: The Civil Administrations of the Mountains, 1983-1990. In: Middle Eastern Studies 29:3, 379-398. 
Harik, Judith P. 1994. "Shaykh al-'Aql” and the Druze of Mount Lebanon: Conflict and Accommodation. In: Middle Eastern Studies 30:3, 461-485.

Harris, William. 1996. Faces of Lebanon: Sects Wars and Global Extensions. Princeton, NJ: Markus Wiener Publishers.

Hazran, Yusri. 2014. The Druze Community and the Lebanese State. Between Confrontation and Reconciliation. Abingdon and New York: Routledge.

Hourani, Albert. 1947. Minorities in the Arab World. New York: Oxford University Press.

Joumblatt, Kamal. 1982. I speak for Lebanon, London: Zed Books.

Kashua, Sa'id. 2004. Soldiers No More: Druze Conscientious Objectors. In: News from Within 20:4, 14-18.

Kastrinou, A. Maria A. 2016. Power, Sect and State in Syria: The Politics Marriage and Identity amongst the Druze. London and New York: I.B. Tauris.

Kastrinou, Maria. 2018. From A Window in Jaramana. Imperial sectarianism and the impact of war on a Druze neighbourhood in Syria. In: Hinnebusch, Raymond and Omar Imady (eds.): The Syrian Uprising: Domestic Origins and Early Trajectory, Abingdon and New York: Routledge, 272-289.

Khnifess, Amir. 2015. Israel and the Druze Political Action: Between Politics of Loyalty and Politics of Violence. PhD Thesis. SOAS, University of London.

Khuri, Fuad I. 2004. Being a Druze. London: Druze Heritage Foundation.

Landis, Joshua. 1998. Shishakli and the Druzes: Integration and Intransigence. In: Philipp, Thomas and Birgit Schaebler (eds.): The Syrian Land: Processes of Integration and Fragmentation. Stuttgart: Franz Steiner Verlag, 369-396.

Lang, Tobias. 2013. Die Drusen in Libanon und Israel: Geschichte, Loyalitäten und Konflikte einer religiösen Gemeinschaft in zwei Staaten. Berlin: Klaus Schwarz Verlag.

Lang, Tobias. 2014. Druze Sheikhs protest in Sweida. In: Syria in Crisis. Carnegie Endowment for International Peace. <http://carnegieendowment. org/syriaincrisis/?fa $=55356>$ (accessed 5 March 2018).

Lang, Tobias. 2015. "Überleben ist wichtiger" Gefährdet ein Konflikt mit den Sunniten die Religionsgemeinschaft des libanesischen Drusenführers Walid Joumblatt?. In: Zenith 2/2015, 28-31.

Leverrier, Ignace. 2014. Les religieux, ultimes garants de la neutralité de la communauté druze de Syrie?. In: Un oeil sur la Syrie. Le Monde Blogs. $<$ http://syrie.blog.lemonde.fr/2014/04/18/les-religieux-ultimes-garants-dela-neutralite-de-la-communaute-druze-de-syrie/> (accessed 5 March 2018). 
Mansour, Bahij. 2014. Israel's Druze Ambassador Can't Defend the Nation-state Law. In: Haaretz 06.12.2014. <https://www.haaretz.com/opinion/.premiumthis-ambassador-cant-defend-that-law-1.5341651> (accessed 5 March 2018).

Nisan, Mordechei. 2010. The Druze in Israel: Questions of Identity, Citizenship, and Patriotism. In: The Middle East Journal 64:4, 575-596.

Parsons, Laila. 2000. The Druze Between Palestine and Israel, 1947-1949. London: Macmillan Press.

Picard, Elizabeth. 2000. The Political Economy of Civil War in Lebanon. In: Heydemann, Steven (ed.): War, Institutions, and Social Change in the Middle East. Berkeley: University of California Press, 292-324.

Rabah, Makram. 2016. Conflict on Mount Lebanon: Collective Memory and the War of the Mountain. Dissertation. Georgetown University.

Rabinovich, Itamar. 1979. The Compact Minorities and the Syrian State, 191845. In: Journal of Contemporary History 14:4, 693-712.

Richani, Nazi. 1990. The Druze of Mount Lebanon. Class Formation During Civil War. In: Middle East Report 162, 26-30.

Richani, Nazih. 1998. Dilemmas of Democracy and Political Parties in Sectarian Societies: The Case of the Progressive Socialist Party of Lebanon, 1949-1996. New York: St. Martin's Press.

Rudnitzky, Arik. 2015. An Analysis of the 20th Knesset Election Results in the Arab Sector 2015. In: Bayan: The Arabs in Israel 5, 3-13.

Salibi, Kamal S. 1965. The Modern History of Lebanon. London: Weidenfeld \& Nicolson.

Salibi, Kamal. 1988. A House of Many Mansions: The History of Lebanon Reconsidered. London: I.B. Tauris.

Schäbler, Birgit. 1996. Aufstände im Drusenbergland: Ethnizität und Integration einer ländlichen Gesellschaft Syriens vom Osmanischen Reich bis zur staatlichen Unabhängigkeit 1850-1949, Gotha: Justus Perthes Verlag.

Schäbler, Birgit. 2013. Constructing an Identity between Arabism and Islam: The Druzes in Syria. In: The Muslim World 101:1, 62-79.

Schaebler, Birgit. 1999. Coming to Terms with Failed Revolutions: Historiography in Syria, Germany and France. In: Middle Eastern Studies. 35:1, 17-44.

Schenk, Bernadette. 1994. Kamāl Ǧunbulāt. Das arabisch-islamische Erbe und die Rolle der Drusen in seiner Konzeption der libanesischen Geschichte. Berlin: Klaus Schwarz Verlag. 
Schenk, Bernadette. 2002. Tendenzen und Entwicklungen in der modernen drusischen Gemeinschaft des Libanon: Versuche einer historischen, politischen und religiösen Standortbestimmung. Berlin: Klaus Schwarz Verlag.

Skovgaard-Petersen, Jacob. N.d. On Taqiyya and Democracy. Unpublished paper. $<$ https://www.academia.edu/34856255/On_Taqiyya_and_Democracy $>$ (accessed 30 March 2018).

Skovgaard-Petersen, Jakob. 1998. Taqìya or Civil Religion? Druze Religious Specialists in the Framework of the Lebanese Confessional State. In: Olsson, Tord, Elisabeth Özdalga and Catharina Raudvere (eds.): Alevi Identity: Cultural, Religious and Social Perspectives. Papers Read at a Conference Held at the Swedish Research Institute in Istanbul, November 25-27, 1996. Istanbul: Numune Matbaasi and Curzon Press, 127-137.

Syria direct. 2015. Idlib Druze agree to forced conversion, destroyed shrines under Nusra rule. In: Syria direct March 17, 2015. <http://syriadirect.org/ news/idlib-druze-agree-to-forced-conversion-destroyed-shrines-undernusra-rule/> (accessed 5 March 2018).

The Daily Star. 2015. Former Druze Rebel dies in Car Accident. In: The Daily Star June 01, 2015. <http://www.dailystar.com.lb/News/Middle-East/2015/ Jun-01/300019-former-druze-rebel-dies-in-car-accident.ashx\#> (accessed 30 March 2018).

The World Bank. 2018. Country Profile Lebanon. The World Bank Group. $<$ http://databank.worldbank.org/data/views/reports/reportwidget. aspx?Report_Name $=$ CountryProfile\&Id $=\mathrm{b} 450 \mathrm{fd} 57 \& \mathrm{tb}$ ar $=\mathrm{y} \& \mathrm{dd}=\mathrm{y} \& \mathrm{inf}=\mathrm{n} \&$ $\mathrm{zm}=\mathrm{n} \&$ country $=\mathrm{LBN}>$ (accessed 30 March 2018).

van Dam, Nikolaos. 2011 (1979). The Struggle for Power in Syria: Politics and Society under the Ba'th Party. London and New York: I. B. Tauris.

van Dam, Nikolaos. 2017. Destroying a Nation: The Civil War in Syria. London and New York: I.B. Tauris.

YouTube channel TheSyrianrev2011. Upload 13 April 2012. <https://www. youtube.com $/$ watch? feature=player_embedded \&v=tyMlGSPRqaY> (accessed 10 September 2016, not accessible anymore).

YouTube channel ZAMAN ALWASL. Upload 26 January 2015. <https://www. youtube.com/watch? $\mathrm{v}=8 \mathrm{Lf} 3 \mathrm{qO}$ YCNuQ $>$ (accessed 5 March 2018). 



\section{Gebhard Fartacek}

\section{Final Comment: Reincarnation and Viability in a Fractured World}

Against the background of the preceding contributions, I would now like to close the circle by returning briefly to the question of the significance of "speaking" children for the viability of Druze society in its present form. Against the background of recent and current conflicts and challenges, what role do these Middle Eastern conceptions of the transmigration of souls play?

All human societies are, of course, characterised by certain contrasts - for example between tradition and modernisation, between religious and secular realities and between different and often competing interests and needs. As Tobias Lang strikingly demonstrates in his differentiated contribution, the Druze community in the Middle East is also characterised by further arresting contrasts: As an ethnic-religious group, the Druze play vastly divergent roles in a diverse mix of political structures, and few settlement areas are as socially and politically fragmented as those of the Druze population. Fortified nationstate borders and military fronts at a geopolitical flashpoint create an empirical environment characterised by insurmountable barriers that inevitably separate individual Druze areas from one another and keep their populations apart. Current and recent armed conflicts have also accentuated divides within individual nation states. The small Druze localities in North-Western Syria, for instance, have been completely cut off from the Druze areas in Suwaydā' for many years, and even within Lebanon, travel between individual Druze areas has increasingly been becoming impossible. And this is before we even begin to speak of the electric fences and minefields that have already isolated Syrian Druze towns and villages on the Golan Heights from each other for decades (cf. Fig. 7).

This geopolitical setting gives rise to the "functionalist question" of nutq and taqammus in a world of friction. The issue appears all the more acute in light of the fact that the Druze are markedly conscious that this important element of the Druze faith sets them fundamentally apart from the followers of the three great book religions - Judaism, Christianity, and Islam - and, indeed, opens them up to accusations of heresy. 


\section{The principle of the transmigration of souls as a cosmological bridge between Druze localities and regions and the rest of the world}

We are all related! - kullna qarä $i b$ ! The principle of rebirth is highlighted very positively as part of a shared Druze group coherence in multiple discourses: We Druze do not fear death, we are the most courageous warriors and support one another - as one common self-attribution runs. It is said that the Druze stick together and treat each other respectfully because they are, as it were, born in each other's houses, and it is thought that every Druze is reborn as rich and as poor, as healthy and as crippled, as a scholar and then a simple farmer, and so on, in accordance with a principle of rotation, so that each individual alternately lives in different social strata. The rotation principle also encompasses kinship and territorial segmentation: Druze expect to be reincarnated in different families and kinship networks in different villages, regions and countries.

As Eléonore Armanet and Lorenz Nigst have shown in their contributions, this rotation is embedded in the discourse on divine justice: Every human being regularly receives new opportunities to make the best of the circumstances they are confronted with in each new life-circuit. As people live under vastly different conditions, it is often considered that it would be unfair if people only had one life and were judged exclusively based on this one life at the Last Judgement.

Being reincarnated in a range of different settings makes sense in this light. Associations are not necessarily made between Druze identity and a shared, contiguous and ethnically homogeneous Druze settlement area, although Druze identity is linked to individual Druze arenas that are clearly ethnically marked: The domes and five-colour flags of the tombs of Druze saints (cf. Fig. 3, 4,5 , and book cover image) - typically sited on mountain peaks or prominent crags - tower over the areas where the Druze live. As Nour Farra Haddad explains compellingly in her contribution, these saints are present in metaphysical form in their sanctuaries and create a direct link to the Druze doctrine of taqammus with their own successive reincarnations. From a spatial point of view, these markers of identity in the form of meticulously tended places of pilgrimage represent an ethnic territorialisation: Here we are, the Druze souls are present here!

That Druze souls are, at least potentially, also reborn in the diaspora and - in the theoretical conception of the Druze - even in imagined Druze communities in China or other worlds makes possible demands for a shared Druze state (a "Druzistan" in analogy to Kurdistan, Arabistan and similar proposed constructs) recede into the background: Druze identity is simply not primarily 
conceived of in nation-state terms. It seems likely that this can neither be explained purely with reference to the principle of taqiya nor be seen solely as a product of the limited opportunities open to the Druze to shape Realpolitik in the Middle East. Paraphrasing Victor Turner somewhat, the construction of ethnicity in the case of the Druze seems to be more a form of "ideological communitas" - and the axiom that Druze are continually reborn in different settings as Druze appears to be a cornerstone of this conception.

\section{"Speaking" children as living bridges between localities, regions and the rest of the world}

When the contributions in this reader are brought together to form a more complete picture, it becomes clear that specific cases of "speaking" children create connections within and between individual Druze areas in very concrete ways. In functionalist terms, individual Druze localities seem to be bound together by nut q cases as well as by marriage alliances. Connections created in this way are also expressed in inner Druze discourses: One only needs to listen to Druze people swapping details on various nutq cases for a short while to discern which places are Druze localities. The same place names fall repeatedly in these conversations, the same regions are mentioned time after time, and at least in every tenth case or so, to speak of nutq also involves thinking beyond a nation-state border. Some rare cases even stretch into the diaspora in America, Australia, and Europe.

Cases of nutq thus link individual Druze localities in the empirically experienced world while also connecting this empirical world with the Druze worldview: "Speaking" children encountered in everyday life embody the principle of the transmigration of souls anchored in Druze cosmology, and the reverse also applies: Abstract cosmological principles take on concrete form in empirically experienced encounters with "speaking" children in everyday life. By way of conclusion, a spotlight will be cast on this epistemological connection below.

\section{The interdependence between taqammus as part of a worldview and empirically existent $n u t q$ cases}

From a systems theory perspective, taqammus and nuṭ are strongly interdependent concepts: There could be no nutq cases without the belief system in which taqammus is a given, as it would not be possible for the "speaking" of children to be recognised as such and interpreted, for the "right" conclusions to be drawn and - even more importantly - for specific cases to be plausible and 
become recognised as such by society (or at least seen as cases that could potentially merit recognition). Specific nutq cases in turn reinforce the worldview by supplying empirical evidence that the principle of taqammus is "true" (Fig. 29).

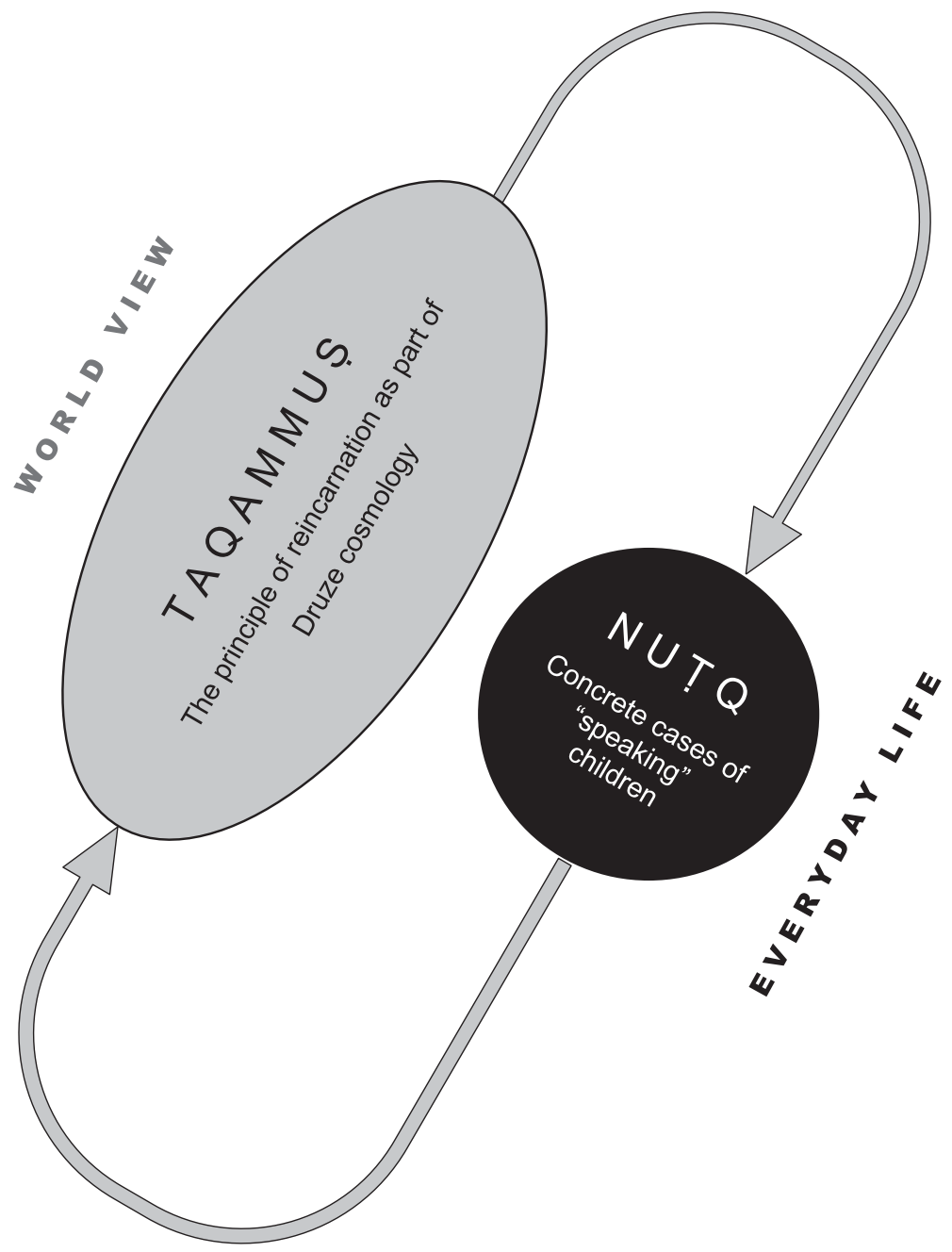

Fig. 29: On the interdependence of nutq (as an empirically perceived phenomenon) and taqammus (as a cosmological explanatory model). Graphics: Gebhard Fartacek, 2020. 
It appears that the Druze conception of reincarnation is a product of systemimmanent interactions between nutq and taqammus in which each provides confirmation for the other. When the Druze speak of reincarnation, this is not simply an abstract answer to the abstract question of what happens to people after they die. The Druze conception also encompasses the cases of "speaking" children who appear precisely when the loss of a fellow human being has created a particularly large void - in cases involving existential threats and (post) traumatic life events.

\section{taqammus | nuṭ as a form of coping with life}

The Druze conceptions of the transmigration of souls help individuals confronted with profound ruptures in their lives to cope better with them emotionally. Rather than offering only the abstract comfort that the deceased has now gone to a "better" place, they point to the continued existence of the Druze community as such - and to biographic ruptures and the deaths of close relatives as an essential part of this process. Social fractures and individual fates are not airily explained away by the Druze conceptions of the transmigration of souls, but instead form an integral part of a wider Druze identity.

It is not insignificant that discourses around nuṭ cases often have a subversive character, cast a spotlight on painful issues, and thus have the potential to challenge circumstances that prevail in the here and now and norms and values associated with them. Nutq cases raise radical questions about the existing order of relationships between people. Personal, family and kinship relationships are newly defined, albeit in a way that gives those affected a certain amount of flexibility to manoeuvre.

The idea of the inevitability of fate that is emphasised in some reincarnation doctrines comes with many qualifiers in the Druze version, which instead accentuates the responsibility of individuals for their actions. At the same time, the Druze conceptions of the transmigration of souls remind people that they do not simply remain Druze for a lifetime but will reappear time and again as Druze in different places. The fact that stories of reincarnation are ceaselessly and vividly told and retold among the Druze may well have something to do with the ability of these narratives to create connections that are conducive to survival in a fractured world. 



\section{Appendix 1: Short Biographies of the Authors}

Eléonore Armanet is a socio-cultural anthropologist and senior lecturer at Aix-Marseille University (France). Her research in Israel, Lebanon and Turkey has mostly focused on the intersections of body, gender and the sacred. For many years, she has also carried out fieldwork among North African and Turkish migrants living in the suburbs of Brussels (Belgium), exploring the impact of migration and exile on mental health and folk-healing systems. Her current institutional affiliations are Aix-Marseille University, Aix-en-Provence and CNRS, Institut d'ethnologie méditerranéenne, européenne et comparative (IDEMEC), Aix-en-Provence, France.

Nour Farra Haddad is a senior researcher and teaches at St-Josef University of Beirut, the American University for Science and Technology (AUST) and at the Lebanese University (UL). She is a specialist in pilgrimages and religious tourism. Her credentials include a PhD in Religious Anthropology (Lebanese University), a master in Anthropology (St-Josef University) and two BS degrees in archeology (Lebanese University) and sociology (St-Josef University). She holds a diploma for tourist guides from the Ministry of tourism and is also a founding member of the Association for the development of pilgrimages and religious tourism in Lebanon (APL).

Gebhard Fartacek is a senior research associate at the Phonogrammarchiv of the Austrian Academy of Sciences (AAS) and a lecturer at the Department of Cultural and Social Anthropology, University of Vienna. He studied social anthropology and a combination of Middle Eastern studies and political science in Vienna and holds a PhD since 2004. His ethnographic fieldwork focuses on pilgrimage and local conceptions of holiness (baraka), stories and discourses dealing with jinns and the evil eye, ethnic-religious boundaries, conflict resolution and coping strategies in the Middle East.

Tobias Lang is a doctoral candidate in Political Science at the University of Vienna, Austria. He authored the german language monograph "The Druze in Lebanon and Israel: History, Conflicts and Loyalties of a Sect in two States" (Berlin: Klaus Schwarz Verlag 2013) and operates the blog MENA Minorities. $\mathrm{He}$ is especially interested in the positioning of the Druze communities in the political systems of their respective states, a subject which he has researched for 
a decade. Lang has commented on numerous occasions on Druze politics and policies on the Druze in international - including Middle Eastern - media. He currently works in Austrian legislative politics.

Lorenz Nigst holds a $\mathrm{PhD}$ in Arabic philology from the University of Vienna. His MA thesis was dedicated to the ascetic poetry of Abū l-Alā' al-Maarrī. His $\mathrm{PhD}$ research focused on Ibn Taymiyya's ideas of Islamic sainthood. From 2016 to 2019, he was a postdoctoral researcher at the Phonogrammarchiv of the Austrian Academy of Sciences. Since October 2019, he is a research associate at the Institute for the Study of Muslim Civilisations (ISMC) at Aga Khan University in London, where he works for the ERC-funded project "Knowledge, Information Technology, and the Arabic book" (KITAB).

Salma Samaha is a landscape engineer with a $\mathrm{PhD}$ in Cultural Landscape from the University of Rome in Italy, a Master's degree in Landscape and Territory Planning from the University of Aix- Marseille in France and an Agricultural Engineering diploma from USEK Lebanon. She co-founded the Landscape department at the Lebanese University, Faculty of Agriculture. Her professional and academic expertise includes cultural landscapes, landscape infrastructure, landscape restoration and impact studies. Samaha is the co-founder and vicepresident of the Lebanese Landscape Association LELA, and was elected as the International Federation of Landscape Architecture IFLA Chair of Education and Academic Affairs. 


\section{Appendix 2: Table of Figures}

Fig. 1: Main settlement areas of the Druze in the Middle East.

Map: Sita Treytl, 2021.

Fig. 2: The Hermon mountain range (jabal ash-shaykh).

Photo: Gebhard Fartacek, 2016.

Fig. 3: The tomb of Sitt Sha wāna in the Golan Heights.

Photo: Gebhard Fartacek, 2017.

Fig. 4: The Druze star in the typical five-colour combination.

Photo: Gebhard Fartacek, 2016.

Fig. 5: An olive tree in the Shüf mountains, Lebanon.

Photo: Gebhard Fartacek, 2016.

Fig. 6: The Druze settlement Bayt Jann, northern Israel.

Photo: Gebhard Fartacek, 2018.

Fig. 7: Divided by barbed wire: the Golan Heights.

Photo: Gebhard Fartacek, 2017.

Fig. 8: Plot construction in narrated nuṭ cases.

Graphics: Gebhard Fartacek, 2020.

Fig. 9: Movement of the soul through its successive life-circuits.

Graphics: Lorenz Nigst, 2020.

Fig. 10: Absence of "speaking".

Graphics: Lorenz Nigst, 2020.

Fig. 11: Onset of "speaking".

Graphics: Lorenz Nigst, 2020.

Fig. 12: "Speaking".

Graphics: Lorenz Nigst, 2020.

Fig. 13: Fully confirmed cases of "speaking".

Graphics: Lorenz Nigst, 2020.

Fig. 14: The external court of the Nabī Bahāàd-Dìn pilgrimage site.

Photo: Nour Farra Haddad, 2014.

Fig. 15: The tomb (darīh) of Nabī Bahāad-Dīn inside the maqām.

Photo: Nour Farra Haddad, 2014.

Fig. 16: Receiving baraka at the tomb of Nabī Bahāad-Dīn.

Photo: Nour Farra Haddad, 2014.

Fig. 17: Cemeteries reserved for dynastic lineage in Báqline.

Photo: Salma Samaha, 2008.

Fig. 18: Druze private cemeteries in the Shüf mountains. Photo: Salma Samaha, 2008. 
Fig. 19: The door shows the phrase al-mawt haqq, which means "death is right". Photo: Salma Samaha, 2008. 166

Fig. 20: Druze family grave chambers in Brīh. Photo: Salma Samaha, 2009. 166

Fig. 21: Various groupings of stones in a rectangle shape. Harfā, Syria. Photo: Salma Samaha, 2009. 170

Fig. 22: Inscription includes only the name of the deceased and the date of the burial. Harfā, Syria. Photo: Salma Samaha, 2009. 170

Fig. 23: Mixed Druzo-Christian cemetery in Brīh. Photo: Salma Samaha, 2008.

Fig. 24: The oak tree as a physical landmark in Ba darān's cemetery. Photo: Salma Samaha, 2008. 174

Fig. 25: Cypress trees in the Druze cemeteries of Nịhā. Photo: Salma Samaha, 2008.

Fig. 26: Olive trees in Mukhtāra Druze cemeteries. Photo: Salma Samaha, 2008.

Fig. 27: Topographical map of Druze settlements in northern Syria. Map created using Google Maps, Tobias Lang, 2021. 182

Fig. 28: Topographical map of Druze settlements in southern Syria, Lebanon, Israel and Jordan. Map created using Google Maps, Tobias Lang, 2021. 182

Fig. 29: On the interdependence of nutq and taqammus. Graphics: Gebhard Fartacek, 2020. 